\author{
UNIVERSIDADE DE SÃO PAULO \\ ESCOLA DE ENGENHARIA DE SÃO CARLOS
}

MARA REGINA PAGLIUSO RODRIGUES

\title{
CARACTERIZAÇÃO E UTILIZAÇÃO DO RESÍDUO DA BORRACHA DE PNEUS INSERVÍVEIS EM COMPÓSITOS APLICÁVEIS NA CONSTRUÇÃO CIVIL
}

Tese apresentada à Escola de Engenharia de São Carlos da Universidade de São Paulo, como parte dos requisitos para obtenção do Título de Doutor em Ciências da Engenharia Ambiental.

Orientador: Prof ${ }^{\mathrm{a}}$. Dra. Akemi Ino

SÃO CARLOS 2008 
AUTORIZO A REPRODUÇÃO E DIVULGAÇÃO TOTAL OU PARCIAL DESTE

TRABALHO, POR QUALQUER MEIO CONVENCIONAL OU ELETRÔNICO, PARA FINS DE ESTUDO E PESQUISA, DESDE QUE CITADA A FONTE.

Ficha catalográfica preparada pela Seção de Tratamento da Informação do Serviço de Biblioteca - EESC/USP

Rodrigues, Mara Regina Pagliuso
R69acterização e utilização do resíduo da borracha de pneus inservíveis em compósitos aplicáveis na construção civil / Mara Regina Pagliuso Rodrigues; orientador; orientadora Dra. Akemi Ino São Carlos, 2008.

Tese (Doutorado - Programa de Pós-Graduação e Área de concentração em Ciências da Engenharia Ambiental) - Escola de Engenharia de São Carlos - Universidade de São Paulo, 2008.

1. Resina poliuretana de mamona. 2. Pneus inservíveis. 3. Resíduo de borracha. 4. Compósito de borracha/PU. I. Título. 


\section{FOIHA DE JULCAMENTO}

Candidntin: Engenheira MARA REGLVA PAGLIISO RODRGULS

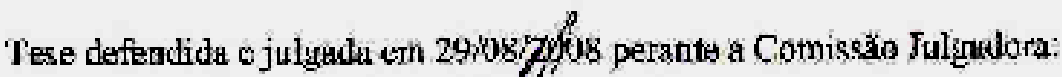

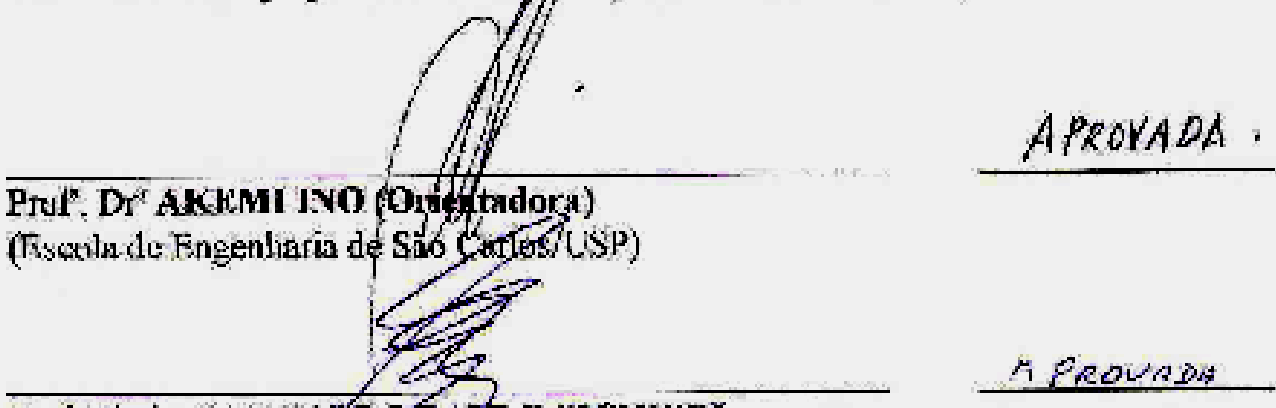

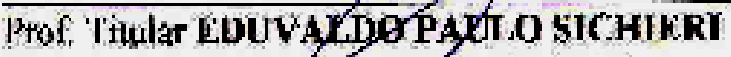

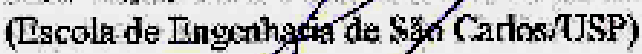

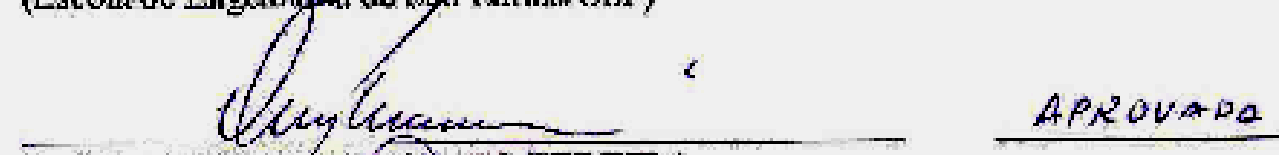

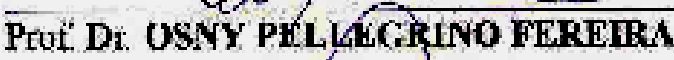

(Ficola de Engenharik do Säo Carlos/USP)

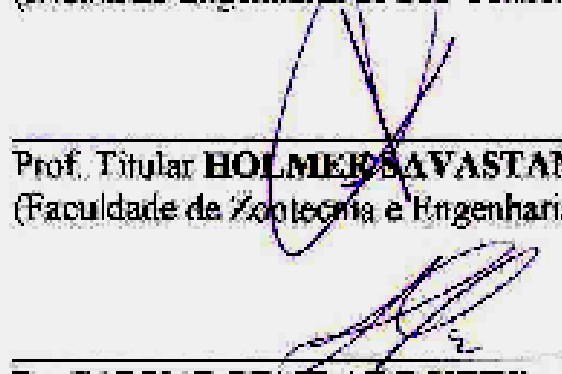

HigitaA

DT. SALVADOR CILARO NETO

(Insfituto de Quimica de Săn CarlesiUSP)

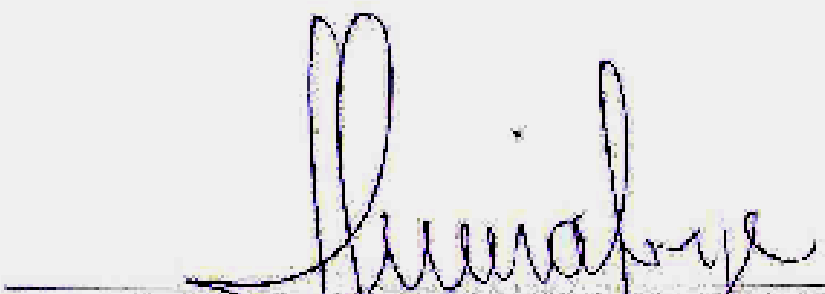

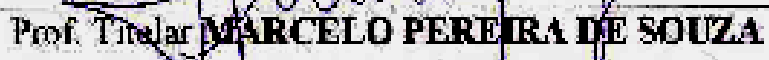

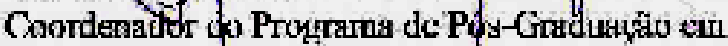

Ciencicias da Fingenharia Ambiental

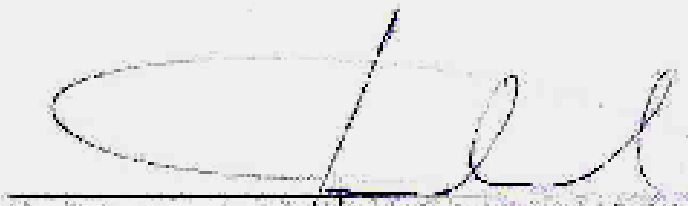

Prol Associado GERALDO ROBERTO MAKTINO DACOSTA

Presidente da/Comissão da Pós-Graduaçä́o da EERSC 
Aos meus filhos Fernando e Felipe, meus pais, meus irmãos e amigos pelo apoio e incentivo. 


\section{AGRADECIMENTOS}

Meu agradecimento aos Professores Dra. Akemi Ino e Dr. Osny Pellegrino Ferreira pela orientação, amizade e confiança durante os anos de convívio e interação pela pesquisa.

Ao Prof. Dr. Gilberto Orivaldo Chierice, ao Dr. Salvador Claro Neto, ao Prof. Dr. Éder Tadeu Gomes Cavalheiro, do GQATP-IQSC, pelo fornecimento da resina PU, por permitir a utilização dos equipamentos do laboratório e pelas importantes sugestões e orientação quanto à pesquisa.

Ao Prof. Dr. Evaldo Luiz Gaeta Espíndola e Profa. Dra Rosane Batistelli pelo apoio às pesquisas durante o período da tese.

Aos colegas Jorge, Simone e João do Laboratório de Materiais das Faculdades Integradas D. Pedro II de São José Rio Preto, Luiz Antonio Ramos do laboratório de química analítica, Sérgio Aparecido Trevelin e Paulo Wanderley Pratavieira do Laboratório de Construção Civil do SAP - EESC pela dedicação e apoio na execução dos ensaios.

Aos meus amigos Cylene, Claudia Cesarino, Célia, Arlete, Thiago, Evandro, Gabriel Castañeda, e todos os demais que contribuíram de alguma forma para este trabalho. 
"Nunca o homem inventará nada mais simples nem mais belo do que uma manifestação da natureza. Dada a causa, a natureza produz o efeito no modo mais breve em que pode ser produzido."

Leonardo da Vinci

“A prática deve estar sempre apoiada na boa teoria." 


\section{SUMÁRIO}

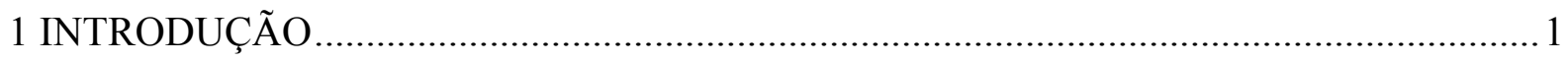

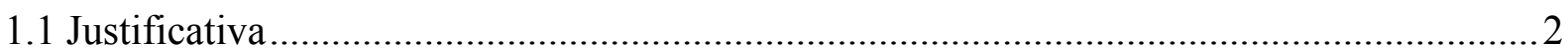

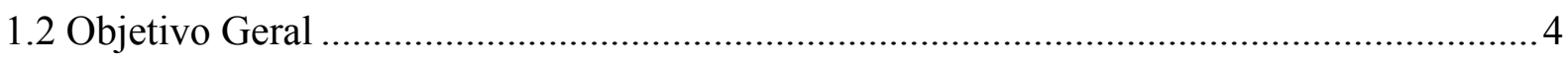

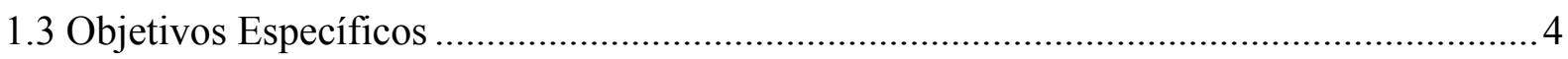

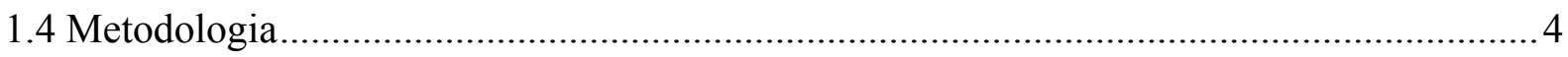

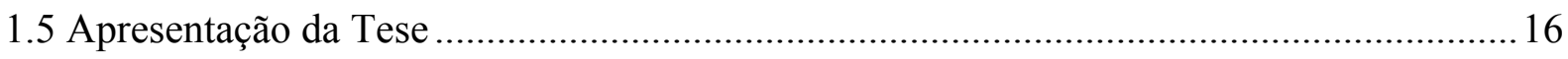

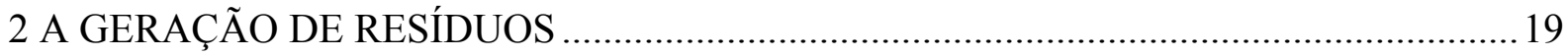

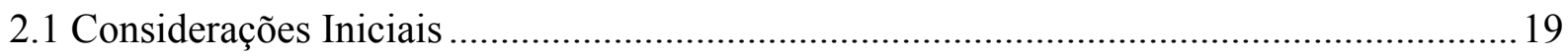

2.2 Classificação dos Resíduos Sólidos Segundo a Origem.................................................22

3 PNEUS, PROCESSO DE PRODUÇÃO, DISPOSIÇÃO FINAL E IMPACTO

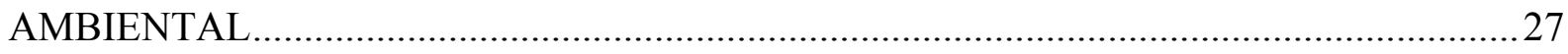

3.1 Breve histórico da borracha empregada em pneus ..................................................... 27

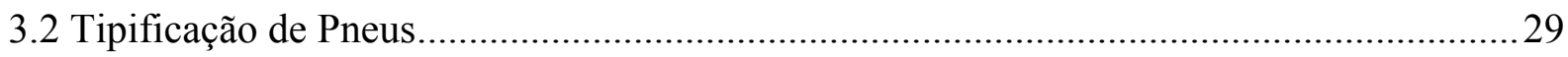

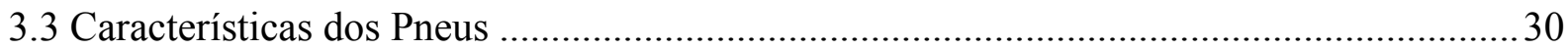

3.4 Impactos Ambientais Decorrentes de Disposição Inadequada de Pneus ........................... 36

4 POLÍTICAS E LEGISLAÇÃO ATUAIS SOBRE PNEUS …............................................. 41

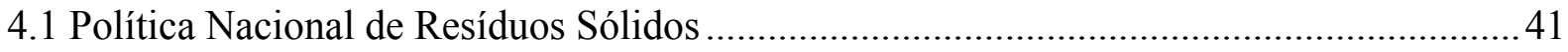

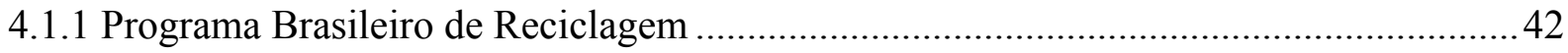

4.1.2 Ações da Associação Nacional da Indústria Pneumática(ANIP) ....................................43

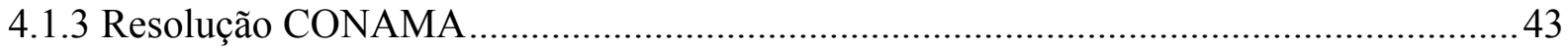


4.2 Dispositivos sobre Tratamento e Disposição de Pneus 46

4.3 Disposições sobre o passivo ambiental 48

4.4 Gestão de Resíduos Sólidos - Pneus 50

4.5 Outras Legislações sobre Resíduos Sólidos - Pneus 52

4.5.1 Lei Estadual no 12.493/1999 - Estado do Paraná. 52

4.5.2 Lei Municipal n. 10.289/1999 - Campinas - Estado de São Paulo 53

4.5.3 Resolução SMA/SS-1/2002 - Estado de São Paulo 54

5 ALTERNATIVAS PARA MINIMIZAÇÃO DE IMPACTOS .............................................55

5.1 Alternativas para Minimização de Impactos Ambientais Gerados por Pneus. 55

5.2 Redução - Reutilização - Reciclagem 57

5.2.1 Redução na Fonte 59

5.2.2 Reutilização de Pneus..... 60

5.2.3 Recauchutagem 60

5.2.4 Resíduos de Recauchutagem 63

5.3 Outras alternativas 64

5.3.1 Recifes Artificiais 64

5.3.2 Quebra-Mares 65

5.3.3 Agricultura. 65

5.3.4 Reciclagem 65

5.3.5 Engenharia Civil.... 67

5.3.6 Regeneração da Borracha 68 
5.3.9 Pirólise

6 NOVOS PROCEDIMENTOS E TECNOLOGIAS DE REDUÇÃO / REUTILIZAÇÃO /

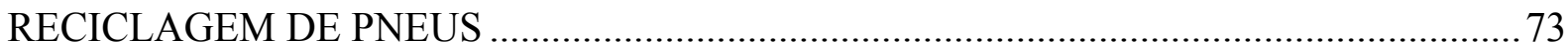

6.1 Experiências em Gerenciamento de Pneus Inservíveis .................................................... 73

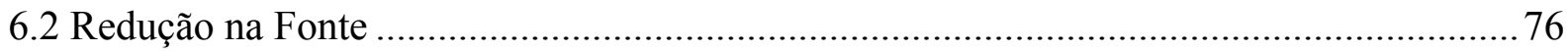

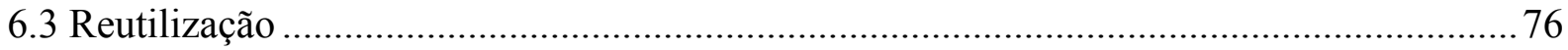

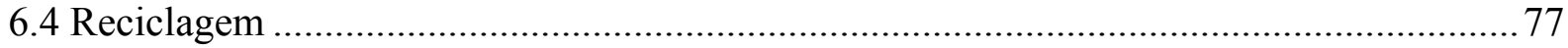

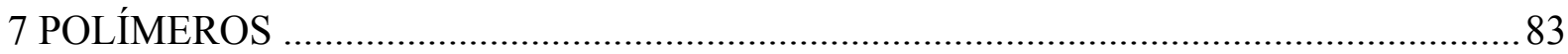

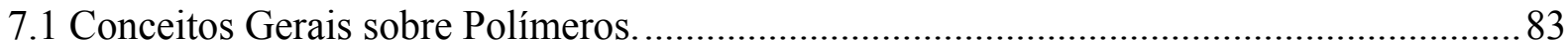

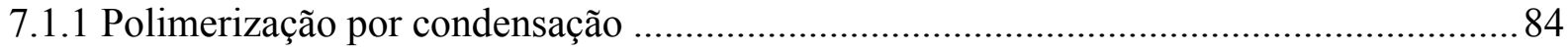

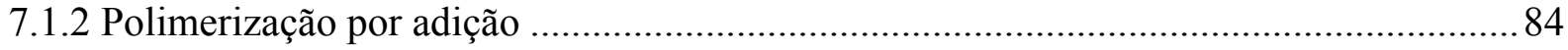

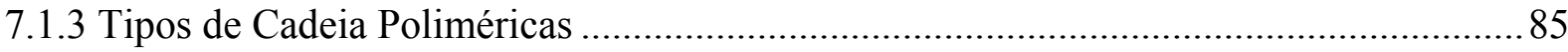

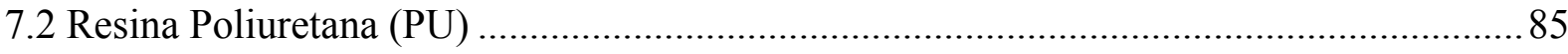

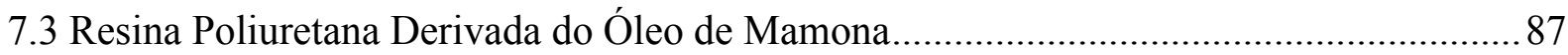

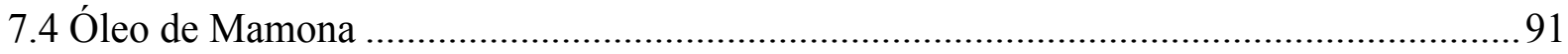

7.5 Utilização de resina poliuretana de óleo de mamona em Compósitos...............................95

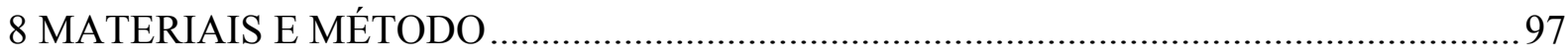

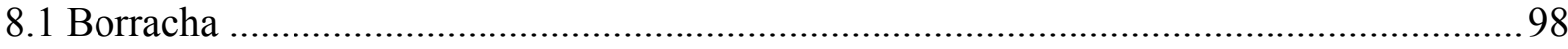

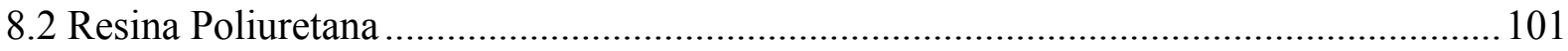

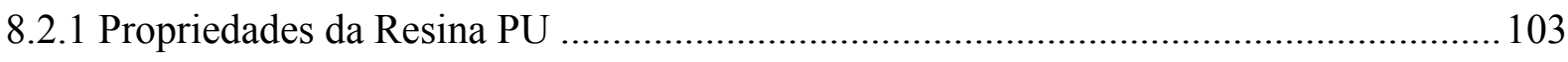

8.2.1.1 Determinação da Densidade da Resina Polimerizada .............................................. 103 
8.3 Compósito de PU e Borracha

8.3.1 Ensaios dos Compósitos de Resina PU e Borracha

8.3.1.1 Microscopia Eletrônica de Varredura (MEV)

8.3.1.2 Ensaio de compressão

8.3.1.3 Ensaio de Tração

8.3.1.4 Ensaio de Rasgamento

8.3.1.5 Resistência ao Fogo

8.3.1.6 Determinação da Resistência à Abrasão.

8.3.1.7 Ensaio de Resistência ao Intemperismo Artificial

8.3.1.8 Ensaio de Dureza

8.3.1.9 Determinação da Densidade

8.3.1.10 Análise Dinâmico Mecânica (DMA).

8.3.1.11 Termogravimetria (TG)

8.3.1.12 Resistência ao Impacto - Ensaio Charpy 
8.3.1.16 Equação de Arrhenius (Viscoelasticidade do Material)

8.3.1.17 Equação de Williams-Landel-Ferry (WLF)

8.3.1.18. Ensaio de Propriedades Térmicas

9 CARACTERIZAÇÃO DOS MATERIAIS

9.1 Resultados obtidos para a resina PU

9.1.1 Ensaio de Determinação da Densidade

9.1.2 Ensaio de Tração e intemperismo.

9.1.3 Ensaio de Compressão

9.1.4 Ensaio de Dureza

9.2 Resultados obtidos com o compósito resina PU e borracha

9.2.1 Distribuição granulométrica

9.2.2 Microscopia eletrônica de varredura (MEV).

9.2.3 Ensaios Mecânicos dos Compósitos

9.2.3.1 Ensaio de compressão dos compósitos

9.2.3.2 Ensaio de Tração

9.3 Ensaio de Rasgamento

9.4 Resistência ao Fogo

9.5 Ensaio de Dureza

9.6 Determinação da Densidade .

9.7 Análise Dinâmico Mecânica (DMA). 
9.12.2 Ensaio de Resistência ao Intemperismo (Raios Ultra-Violeta)

9.13.1 Fluência - CREEP (Curvas Master)

9.13.2 Equação de Arrhenius

9.13.3 Equação de Williams-Landel-Ferry (WLF)

10 UTILIZAÇÕES POTENCIAIS DO COMPÓSITO

10.1 Placas de Revestimento de Pisos

10.2 Painéis Sanduíche

10.2.1 Comportamento do Painel Sanduíche à Flexão

10.3 Aparelhos de Apoio para Estruturas

10.3.1 Resultados dos experimentos

10.3.2 Propriedades do Material

10.3.3 Propriedades típicas dos elastômeros empregados em aparelhos de apoio

10.3.4 Fator de forma

10.3.5 Dureza

10.3.6 Propriedades dinâmicas dos elastômeros 


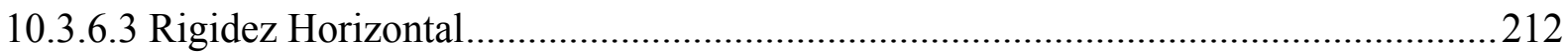

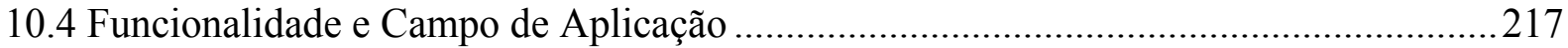

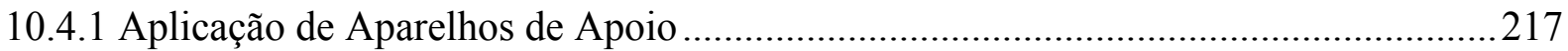

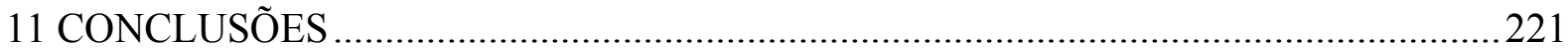

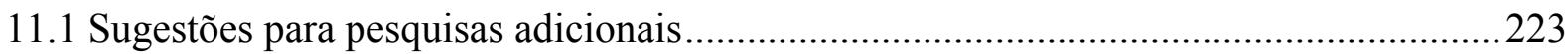

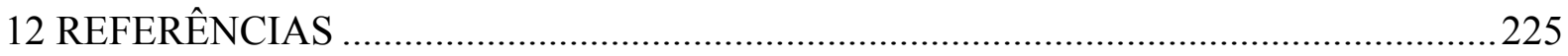

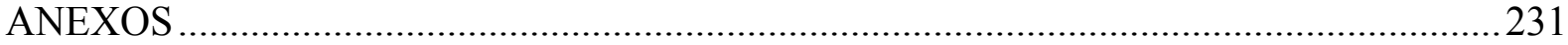




\section{PUBLICAÇÕES}

RODRIGUES JORGE, Mara Regina Pagliuso; INO, Akemi; FERREIRA, Osny Pellegrino. Produtos derivados da reciclagem de pneus inservíveis. In: CHAHUD, Eduardo (Org.). Reciclagem de resíduos para construção civil. Belo Horizonte: Fumec, 2007. v.1. p. 217230. ISBN 978-85-61258-01-06.

RODRIGUES JORGE, Mara Regina Pagliuso; INO, Akemi; CLARO NETO, Salvador; FERREIRA, Osny Pellegrino. Composto de borracha de pneus inservíveis e sua utilização em novos produtos para a construção civil. In: CHAHUD, Eduardo (Org.). Reciclagem de resíduos para construção civil. Belo Horizonte: Fumec, 2007. v.1. p. 231-245. ISBN 97885-61258-01-06.

RODRIGUES JORGE, Mara Regina Pagliuso; SHULTZ, Patrícia; FERREIRA, Osny Pellegrino. Painéis sanduíche contendo materiais compostos constituído de resina poliuretana e resíduos. In: CHAHUD, Eduardo (Org.). Reciclagem de resíduos para construção civil. Belo Horizonte: Fumec, 2007. v.1. p. 293-311. ISBN 978-85-61258-01-06.

RODRIGUES JORGE, Mara Regina Pagliuso; INO, Akemi; CLARO NETO, Salvador; FERREIRA, Osny Pellegrino. Compósitos formados por borracha de pneus inservíveis e resina poliuretana de óleo de mamona aplicados a aparelhos de apoio. In: VI Simpósio EPUSP de Estruturas de Concreto. São Paulo: VI Simpósio EPUSP de Estruturas de Concreto, 2006. p. 833-843. CDROM.

RODRIGUES JORGE, Mara Regina Pagliuso; FERREIRA, Osny Pellegrino; CLARO NETO, Salvador; INO, Akemi. Aparelhos de apoios formados por compósitos de borracha de pneus inservíveis e resina poliuretana de óleo de mamona. In: XXXII Jornada

Sulamericanas de Engenharia. Campinas: Mauro Augusto Demarzo, 2006. v. I. p. 611-620.

RODRIGUES JORGE, Mara Regina Pagliuso; FERREIRA, Osny Pelegrino; INO, Akemi. Produtos derivados da reciclagem de pneus inservíveis. In: III Congresso Brasileiro ICTR 2006. Gestão Ambiental e Desenvolvimento Sustentável. Resíduo: Desafio Brasileiro. Brotas: Rimi, 2006. p. 448.

RODRIGUES JORGE, Mara Regina Pagliuso; FERREIRA, Osny Pellegrino; INO, Akemi. Materiais provenientes da reciclagem de pneus inservíveis e seus usos potenciais. In: Conferência Brasileira sobre Materiais e Tecnologias não-convencionais na Construção Ecológica e Sustentável. Brasil Nocmat. Salvador: NOCMAT. Rio de Janeiro: ABMTENC, 2006. v. 1.p. 1-11.

RODRIGUES JORGE, Mara Regina Pagliuso; RAMOS, Luiz Antonio; CLARO NETO, Salvador; FERREIRA, Osny Pellegrino. Caracterização de compósito de resina poliuretana 
derivada de óleo de mamona e borracha de pneus inservíveis. In: V Congresso Brasileiro de Análise Térmica e Calorimetria. Poços de Caldas: Livro de Resumos, 2006. v. I. p. 38.

RODRIGUES JORGE, Mara Regina Pagliuso; RAMOS, Luiz Antonio; FERREIRA, Osny Pellegrino; CLARO NETO, Salvador; CAVALHEIRO, Eder Tadeu Gomes. Estudo termogravimétrico de compósito de borracha de pneus inservíveis/resina poliuretana. In: $\mathrm{V}$ Congresso Brasileiro de Análise Térmica e Calorimetria. Poços de Caldas: Livro de Resumos, 2006. v. I. p. 39.

RODRIGUES JORGE, Mara Regina Pagliuso; SCHULTZ, Patrícia; FERREIRA, Osny Pellegrino. Componentes para construção civil constituídos a partir de resíduos de borracha e pneus estabilizados. In: IV Congresso Latinpamericano sobre Confort Y

Comportamiento Térmico de Las Edificaciones. Ciudad de México. Confort e Eficiencia Energética en la Arquictetura. México: Grupo Noriega, 2005. v. II. p. 491-498.

RODRIGUES JORGE, Mara Regina Pagliuso; FERREIRA, Osny Pellegrino; CLARO NETO, Salvador; INO, Akemi. Compuestos con goma de neumáticos inútiles y su utilización en nuevos productos para el mercado de la construcción. In: III Conferencia Internacional Ecomateriales. Santa Clara-Cuba, 2005. v. I. p. 54.

RODRIGUES JORGE, Mara Regina Pagliuso; FIORITI, Cesar Fabiano; INO, Akemi. Fabricación de baldosas monocapa de uso exterior con fibras de caucho procedentes de neumáticos usados. In: III Conferencia Internacional Ecomateriales. Santa Clara: Resúmenes, 2005.

RODRIGUES JORGE, Mara Regina Pagliuso; RAMOS, Luiz Antonio; FERREIRA, Osny Pellegrino; CAVALHEIRO, Eder Tadeu. Estudo termogravimétrico do compósito de borracha de pneus inservíveis/resína poliuretana. In: II Encontro Regional dos Usuários de Técnicas Termoanalíticas. São Carlos: II Encontro Regional dos Usuários de Técnicas Termoanalíticas, 2005. v. I. p. 41.

RODRIGUES JORGE, Mara Regina Pagliuso; FERREIRA, Osny Pellegrino; CLARO NETO, Salvador; INO, Akemi. Compósitos de borracha de pneus inservíveis e resina poliuretana de óleo de mamona utilizados como aparelhos de apoios em estruturas prémoldadas. In: XI Simpósio do Curso de Pós-Graduação em Ciências da Engenharia Ambiental. São Carlos: XI Simpósio do Curso de Pós-Graduação em Ciências da Engenharia Ambiental, 2005. v. I.

RODRIGUES JORGE, Mara Regina Pagliuso; FERREIRA, Osny Pellegrino; CLARO NETO, Salvador. Utilization of scrap tires in the production of building materials to civil construction. In: Internarional RILEM Conference on the Use of Recycled Materials in Building and Structures. Barcelona. Bagneux: RILEM Publications S.A.R.I, 2004. v.1. p. 472-479. 
RODRIGUES JORGE, Mara Regina Pagliuso; CLARO NETO, Salvador; FERREIRA, Osny Pellegrino. Aproveitamento da borracha de pneus inservívies na produção de componentes para construção. In: Congresso Brasileiro de Ciência e Tecnologia em Resíduos e Desenvolvimento Sustentável \& NISAM 2004 - Ciclo de Conferência sobre Política e Gestão Ambiental. Florianópolis: ICTR 2004. v. único. p. 25.

RODRIGUES JORGE, Mara Regina Pagliuso; FERREIRA, Osny Pelegrino; CLARO NETO, Salvador. Aproveitamento da borracha de pneus inservíveis na produção de componentes para construção civil. In: X Simpósio do Curso de Pós-Graduação em Ciências da Engenharia Ambiental. São Carlos: X Simpósio do Curso de Pós-Graduação em Ciências da Engenharia Ambiental, 2004. v. único. p. 28.

RODRIGUES JORGE, Mara Regina Pagliuso; HANAI, Frederico Yuri; FIORITTI, Cesar Fabiano. Resíduos sólidos de pneus: impactos, políticas e soluções. In: Anais III Encontro de Pesquisas e Pós-Graduação. Fortaleza: CEFET/CE, 2003. v. 1. p. 46.

\section{PRODUTOS TECNOLÓGICOS - PATENTE DE INVENÇÃO JUNTO AO INPI}

RODRIGUES JORGE, Mara Regina Pagliuso; FERREIRA, Osny Pellegrino. Utilização das fibras de nylon provenientes da moagem de pneus inservíveis por meio de sua aglomeração com resina poliuretana e seu processo de produção. 2006.

RODRIGUES JORGE, Mara Regina Pagliuso; FERREIRA, Osny Pellegrino. Reutilização da borracha proveniente da moagem de pneus inservíveis por meio de sua aglomeração com resina poliuretana de origem vegetal e seu processo de produção. 2005. 


\section{RESUMO}

RODRIGUES, M. R. P. Caracterização e utilização do resíduo da borracha de pneus inservíveis em compósitos aplicáveis na construção civil. 2008. 256f. Tese de (Doutorado) - Escola de Engenharia de São Carlos, Universidade de São Paulo, São Carlos, 2008.

Este trabalho tem como objetivo o desenvolvimento de uma tecnologia para a atenuação do impacto provocado pelo passivo ambiental gerado por pneus inservíveis, conjuntamente ao desenvolvimento de novos materiais compostos para uso na construção.Os pneus têm uma estrutura física especial, com grande resistência e durabilidade, mesmo ao término de sua vida útil e, por isso, sua deposição em aterros sanitários é inadequada, já que eles não permitem compactação, tornando-se favoráveis para a criação agentes causadores de enfermidades e oferecem grandes riscos de incêndios, o que acarreta sérios danos ao meio ambiente. A tecnologia desenvolvida utilizou a borracha de pneus inservíveis, após serem picados por processo mecânico, segundo diferentes tamanhos, para a composição de produtos de baixo custo e utilizáveis na construção civil em elementos construtivos, placas de amortecimento sonoro e de revestimento de pisos para edificações, sinalização horizontal em vias públicas, absorvedores de impacto em estradas,etc. $\mathrm{O}$ agente de aglomeração utilizado foi a resina poliuretânica derivada do óleo de mamona (Ricinus communis), uma fonte renovável, que também apresenta estabilidade física e química, e um excelente desempenho como aglomerante. $\mathrm{O}$ composto obtido foi testado com relação à durabilidade, às propriedades mecânicas como resistência à compressão e tração, módulo de elasticidade e fluência por meio da termo análise, demonstrando resultados satisfatórios e confirmada sua aplicação em vários campos da construção civil.

Palavras-chave: Pneus inservíveis. Resíduo de borracha. Compósito/PU. Resina poliuretana. Mamona. 


\begin{abstract}
RODRIGUES, M.R.P. Caracterization and Utilization of the waste rubber from scrap tires in composites to use in the civil construction. 2008. 256f. Ph. D. Thesis - School of Engineering of São Carlos, University of São Paulo, São Carlos, 2008.
\end{abstract}

The objective of this work is to develop a technology for the impact attenuation caused by the passive environmental generated by scrap tires, jointly to the development of new composites for being used in construction. The tires have a special physical structure, with great resistance and durability, also in the term of their useful life, therefore, their deposit in landing fields are inadequate, once they do not allow compacting, becoming favorable for the creation of causes of diseases and they offer great fires risks, what causes serious damages to the environment. The developed technology used the rubber of useless tires, after being fragmented by mechanic process, according to different sizes, for the composition of products of low cost to be used in the civil construction in constructive elements, noise reduction plates and lining of floors for constructions, horizontal signaling in public ways, impact insulating in highways, and so on. The agent of mass used was the polyurethane resin, derived of the castor oil (Ricinus communis), a renewable source that also presents physical and chemical stability, and a good bonding behavior. The obtained composite was tested in relation to durability behavior, mechanical properties which the compression forces and tension, and also its modulus of elasticity and creep by use of thermo analisys, demonstrated satisfactory results and confirmed its application in a many fields of the civil construction.

Keywords: Scrap tires. Rubber recycling. Polyurethane composite. Polyurethane resin. 


\section{LISTA DE ABREVIATURAS}

ABNT Associação Brasileira de Normas Técnicas

ANIP Associação Nacional da Indústria de Pneumáticos

CEMPRE Compromisso Empresarial para Reciclagem

CETESB Companhia de Tecnologia de Saneamento Ambiental

CNEN Conselho Nacional de Energia Nuclear

CONAMA Conselho Nacional do Meio Ambiente

COPASA Companhia de Saneamento de Minas Gerais

DMA Dinamical Mechanical Thermo Analisys

EPS Poliestireno expandido

ETAS Estações de Tratamento de Água

ETES Estações de Tratamento de Esgotos

EUA Estados Unidos as América

IAP Instituto Ambiental do Paraná

IBAMA Instituto Brasileiro do Meio Ambiente

III Três

IPCT Instituto de Pesquisa, Ciência e Tecnologia

IQ-USP Instituto de Química da Universidade de São Paulo

ISOPET Blocos em concreto leve com EPS (isopor) reciclado, utilizando garrafas plásticas inteiras recicladas, posicionadas na horizontal ou na vertical

IXX Dezenove

Kg Quilo

LQATP Laboratório de Química Analítica e Tecnologia de Polímeros

MDIC Ministério do Desenvolvimento, Indústria e Comércio 
xxviii

MEV Microscopia Eletrônica de Varredura

NBR Norma Brasileira Regulamentadora

$\mathrm{NCO} \quad$ Monômero que ligado ao $\mathrm{OH}$ dá a molécula poliuretana

RCM Rivers Council of Minnesota

PU Resina poliuretana

SEBRAE Serviço de Apoio às Micros e Pequenas Empresas

SECEX Secretaria de Comércio Exterior

SISNAMA Sistema Nacional do Meio Ambiente

TDF $\quad$ Tyred Diesel Fuel

TEC Tarifa Externa Comum

TG Termogravimetria

UNICAMP Universidade Estadual de Campinas

UV Ultravioleta 


\section{LISTA DE FIGURAS}

Figura 1.1 - Fluxograma das ações empreendidas na fase inicial

Figura 1.2 - Experiências para a definição do composto constituído a partir dos materiais gerados pela usina de reciclagem de pneus inservíveis. 6

Figura 1.3 - Desenvolvimento de equipamentos para ensaios............................................ 8

Figura 1.4 - Abordagem metodológica para caracterização do compósito 10

Figura 1.5 - Abordagem metodológica para caracterização das propriedades mecânicas ....... 11

Figura 1.6 - Abordagem metodológica para caracterização das propriedades físicas..............13

Figura 1.7 - Metodologia para caracterização das propriedades termoanalíticas.....................13

Figura 1.8 - Abordagem metodológica para uso potencial do compósito ...............................15

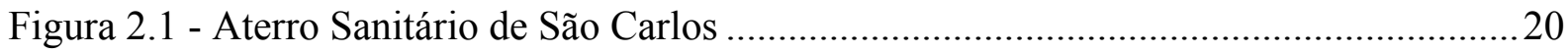

Figura 2.2 - Aterro Sanitário de São Carlos ..................................................................... 21

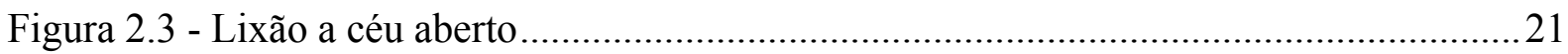

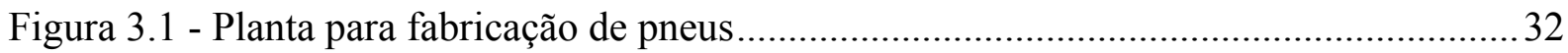

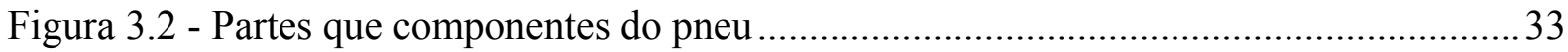

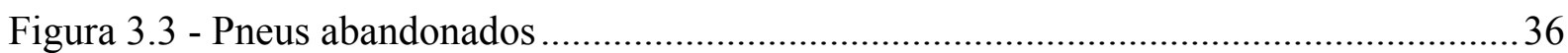

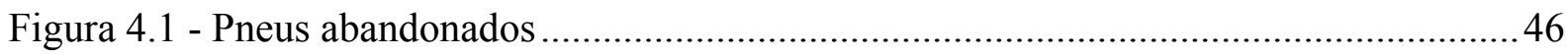

Figura 7.1 - Esquema de um processo conhecido para preparação de poliuretanas..................89

Figura 7.2 - Rota de síntese para a formação do pré-polímero poliuretana elastomérica ........90

Figura 7.3 - Estrutura do óleo de mamona mostrando seus principais pontos de modificações estruturais

Figura 7.4 - Fluxograma do processo de extração do óleo de mamona ..................................94

Figura 7.5 - Processo representativo de extração do óleo de mamona....................................95

Figura 7.6 - Folhas, fruto e semente da mamona.................................................................. 95 
Figura 8.1 - Maquete de usina de reciclagem obtida do catálogo do fabricante (trituradores de mandíbulas).

Figura 8.2 - Maquete de usina de reciclagem obtida do catálogo do fabricante (etapa de separação dos constituintes do pneu).

Figura 8.3 - Maquete de usina de reciclagem obtida do catálogo do fabricante (peneiradores)

Figura 8.4 - Moenda da usina de reciclagem EcoBalbo (trituradores de mandíbulas) - foto do autor 100

Figura 8.5 - Entrada dos pneus na moenda, depois da retirada dos talões (EcoBalbo) - foto do autor..... 100

Figura 8.6 - Partículas moídas de borracha de pneu, constituindo as quatro amostras obtidas da usina de reciclagem.

Figura 8.7 - Planta Mamona (Ricinus communis), Pré-polímero e Poliol que compõem a resina poliuretana de origem vegetal 102

Figura 8.8 - Representação da formulação da resina para sua aplicação 102

Figura 8.9 - Ensaio de desgaste à abrasão 104

Figura 8.10 - Ensaio de tração em equipamento do GQATP- IQSC. 105

Figura 8.11 - Ensaio de compressão axial da resina poliuretana utilizada como aglomerante do compósito 106

Figura 8.12 - Sentido da rotação das placas de resina no ensaio de intemperismo artificial . 108 Figura 8.13 - Ensaio de dureza da resina PU 109

Figura 8.14 - Seqüência da mistura de partículas de borracha e a resina PU, e sua moldagem na fôrma metálica

Figura 8.15 - Dispositivo de aquecimento da fôrma, acoplado à prensa...... 112

Figura 8.16 - Forma cilíndrica e corpos de prova do ensaio à compressão 114 
Figura 8.17 - Corpo de prova sendo ensaiado à compressão axial

Figura 8.18 - Fôrma utilizada para moldagem do corpo de prova do ensaio à tração e gravatas utilizadas no ensaio. 116

Figura 8.19 - Garras do equipamento e corpo de prova rompido à tração 116

Figura 8.20 - Ensaio de rasgamento com o corpo de prova sendo rompido. 117

Figura 8.21 - Ensaio de desgaste à abrasão 119

Figura 8.22 - Câmara de raios UV com os corpos de prova colocados 120

Figura 8.23 - Fôrma da placa recém moldada do compósito

Figura 8.24 - Corpo de prova submetido a ensaio de DMA, mostrando a injeção de $\mathrm{N}_{2}$ para resfriamento a $-80^{\circ} \mathrm{C}$ 122

Figura 8.25 - Corpo de prova para ensaio de TG e resíduo final

Figura 8.26 - Equipamento e preparação dos corpos de prova utilizados no ensaio infravermelho

Figura 8.27 - Preparação das amostras em N2 e detalhes do equipamento de ensaio 126

Figura 8.28 - Seção de ruptura de um corpo de prova submetido ao ensaio Charpy 127

Figura 8.29 - Amostras ensaiadas e aparelho para medir resistividade do corpo 128

Figura 8.30 - Curvas de um polímero submetido ao ensaio DMA 130

Figura 8.31 - Exemplo da construção da curva máster

Figura 8.32 - Curva relativa a Equação de Arrhenius 132

Figura 8.33 - Curva relativa a Equação de Williams-Landel-Ferry (WLF) 133

Figura 8.34 - Representa os intervalos onde valem as equações de Arrhenius e WLF 133

Figura 8.35 - Arranjo experimental com dispositivos utilizados no ensaio. 135

Figura 8.36 - Corpo de prova submetido ao ensaio. 135

Figura 9.1 - Tensão de ruptura e deformação das amostras mantidas em ambiente normal .. 138 
xxxii

Figura 9.2 - Tensão de ruptura e deformação das amostras mantidas na câmara de intemperismo (radiação ultravioleta) por 1000 horas..... 139

Figura 9.3 - Tensão de ruptura e deformação dos corpos de prova....................................... 140

Figura 9.4 - Curva da mistura das quatro granulometrias, segundo a zona $3 . . . \ldots \ldots \ldots \ldots \ldots \ldots \ldots . . . . . .144$

Figura 9.5 - Curva representativa da mistura das quatro granulometrias, segundo a zona 4.144 Figura 9.6 - Curvas para determinação das frações das amostras segundo a curva média da zona 3.

Figura 9.7 - Curvas para determinação das frações das amostras segundo a curva média da zona 4. 146

Figura 9.8 - Imagens em diferentes ampliações da seção fraturada do compósito, com $15 \%$ de resina, moldado a frio e densidades de $1,16 \mathrm{~g} / \mathrm{cm} 3$ e de $1,06 \mathrm{~g} / \mathrm{cm}^{3}$ 147

Figura 9.9 - Imagens em diferentes ampliações da seção fraturada do compósito, com 15\% de resina, moldado à quente e densidades de $1,06 \mathrm{~g} / \mathrm{cm} 3 \mathrm{e}$ de $1,16 \mathrm{~g} / \mathrm{cm}^{3}$ 149

Figura 9.10 - Imagens em diferentes ampliações da seção fraturada do compósito, com 15\% de resina, moldado à quente e a frio, de mesma densidade $1,16 \mathrm{~g} / \mathrm{cm}^{3}$ 150

Figura 9.11 - Imagens em diferentes ampliações da seção fraturada do compósito, com 20\% e $18 \%$ de resina, moldado à quente, e de mesma densidade $1,16 \mathrm{~g} / \mathrm{cm}^{3}$.

Figura 9.12 - Curvas representativas dos resultados dos ensaios de compressão e tração em amostra de pneu agrícola 158

Figura 9.13 - Curva representativa do resultado do ensaio de compressão em compósito com teor de resina de $20 \%$ 159

Figura 9.14 - Curva representativa do resultado do ensaio de compressão em compósito com teor de resina de $18 \%$ 159

Figura 9.15 - Curvas representativas dos resultados dos ensaios de compressão e tração em compósito de granulometria na zona 3 e teor de resina $15 \%$ 160 
Figura 9.16 - Curvas representativas dos resultados dos ensaios de compressão e tração em compósito de granulometria na zona 3 e teor de resina $12 \%$ 160

Figura9.17 - Curvas representativas dos resultados dos ensaios de compressão e tração em compósito de granulometria na zona 4 e teor de resina $15 \%$ 161

Figura 9.18 - Curvas representativas dos resultados dos ensaios de compressão e tração em compósito de granulometria na zona 4 e teor de resina $12 \%$ 161

Figura 9.19 - Curvas obtidas para o pneu e a resina PU. 168 Figura 9.20 - Curvas obtidas para os compósitos com teores de resina de 12\%, 15\%, 18\% e de $20 \%$ 168

Figura 9.21 - Curva TG para o pneu puro, a resina poliuretana e dos compósitos com teores de resina em relação à borracha de: $12 \%, 15 \%, 18 \%$ e $20 \%$ para a zona 3 e $12 \%$ e $15 \%$ para a

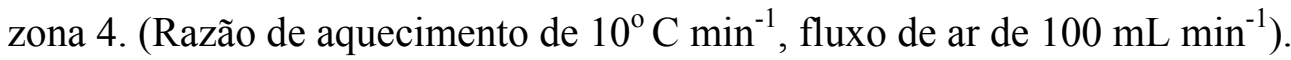

Figura 9.22 - Espectro na região do infravermelho dos resíduos dos diferentes compósitos obtidos a $800^{\circ} \mathrm{C}$ em atmosfera de ar

Figura 9.23 - Seções fraturadas dos corpos de prova submetidos ao ensaio Charpy 174

Figura 9.24 - Compósito com teor $12 \%$

Figura 9.25 - Compósito com teor $15 \%$

Figura 9.26 - Compósito com teor $18 \%$

Figura 9.27 - Compósito com teor 20\%

Figura 9.28 - Curvas Master do Neoprene e dos compósitos.

Figura 9.29 - Valores gráficos obtidos no ensaio DMA por meio da equação de Arrhenius. 191

Figura 9.30 - Valores gráficos obtidos no ensaio DMA por meio da equação de WLF 194

Figura 10.1 - Forma do revestimento e placa terminada 198

Figura 10.2 - Ilustração de painel sanduíche 199

Figura 10.3 - Núcleo do painel compósito borracha/PU 200 
xxxiv

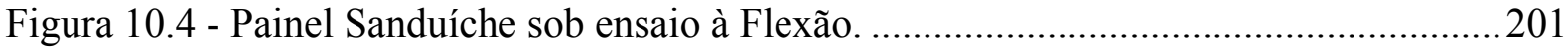

Figura 10.5 - Comportamento à flexão: Sanduíche com núcleo borracha D-02 …................202

Figura 10.6 - Comparativo de carga à flexão: Sanduíche borracha com diferentes densidades

Figura 10.7 - Produção do elemento Aparelho de apoio 204

Figura 10.8 - (a) Montagem do aparelho de apoio no dispositivo para ensaio de distorção , (b) ensaio de distorção e (c) Aparelho de apoio deformado 205

Figura 10.9 - Tensão x Deformação 205

Figura 10.10 - Carga x Deslocamento 205

Figura 10.11 - Deformação dos corpos de prova 207

Figura 10.12 - Cargas atuantes no conjunto de camadas do aparelho de apoio 211

Figura 10.13 - Esquema das cargas atuantes no aparelho de apoio

Figura 10.14 - Esquema das cargas atuantes no aparelho de apoio

Figura 10.15 - Esquema das cargas atuantes no aparelho de apoio 216

Figura 10.16 - Esquema das cargas atuantes no aparelho de apoio 216

Figura 10.17 - Exemplo de uma aplicação potencial para o compósito desenvolvido 218

Figura 10.18 - Apresenta o aparelho de Apoio aplicado na ETE São Carlos. 220

Figura 11.1 - Ensaio à flexão de placa cimentícia com partículas de borracha como agregado 224

Figura 11.2 - Seqüência de execução de placa com fibras de nylon em matriz polimérica ...224 


\section{LISTA DE TABELAS}

Tabela 3.1 - Composição média do pneu

Tabela 3.2 - Composição da banda de rodagem de um pneu

Tabela 7.1 - Polímeros obtidos por reações de policondensação

Tabela 9.1 - Resultados do ensaio de resistência ao intemperismo artificial

Tabela 9.2 - Resultados do ensaio compressão

Tabela 9.3 - Valores médios de dureza na escala Shore A

Tabela 9.4 - Graduação das partículas segundo seus diâmetros comerciais

Tabela 9.5 - Porcentagens retidas nas peneiras da serie normal, das amostras misturadas em quantidades iguais

Tabela 9.6 - Valores da resistência à compressão com teores de $12 \%$ e $15 \%$ de resina, com a granulometria da borracha segundo a zona 4

Tabela 9.7 - Valores estatísticos das resistências à compressão dos compósitos

Tabela 9.8 - Resistência à compressão dos compósitos com granulometria na zona3 e as porcentagens de resina PU utilizadas

Tabela 9.9 - Resultados da análise estatística de tensão na zona 3, com os diferentes teores de resina.

Tabela 9.10 - Resultados da análise estatística de deformação na zona 3, com os diferentes teores de resina

Tabela 9.11 - Valores dos ensaios de tração para os compósitos de $12 \%, 15 \%, 18 \%$ e $20 \% 164$

Tabela 9.12 - Valores encontrados para os compósitos, segundo a Norma ASTM D 624 .... 165

Tabela 9.13 - Valores de dureza encontrados para o pneu e o compósito

Tabela 9.14 - Valores de densidade encontrados para o pneu e o compósito 167 
xxxvi

Tabela 9.15 - Valores dos Módulos de elasticidade (E), de armazenamento (E'), e de perda (E') obtidos com os compósitos, a resina e o pneu 169

Tabela 9.16 - Valores obtidos no ensaio TG para os materiais puros e compósito segundo composição granulométrica nas zonas 3 e 4

Tabela 9.17 - Resultados obtidos nos ensaio de impacto Charpy

Tabela 9.18 - Análise estatística dos resultados do Ensaio Charpy..... 175

Tabela 9.19 - Valores obtidos para diferentes materiais conhecidos 176

Tabela 9.20 - Resultados dos ensaios elétricos realizados nos compósitos

Tabela 9.21 - Valores obtidos no ensaio de abrasão, utilizando areia de diâmetro variando de $0,1 \mathrm{~mm}$ a $0,6 \mathrm{~mm}$ 179

Tabela 9.22 - Análise dos resultados obtidos 179

Tabela 9.23 - Valores de transição vítrea dos compósitos antes e depois de serem sujeitos a câmara de intemperismo 182

Tabela 9.24 - Parâmetros retirados das curvas constantes da Figura 9.28.

Tabela 9.25 - Valores da Energia de Ativação para os compósitos e o Neoprene utilizado como referência com base na equação de Arrhenius

Tabela 9.26 - Valores de C1 e C2 obtidos para os diferentes compósitos e Neoprene 195

Tabela 9.27 - Resultados obtidos com os ensaios de Propriedades Térmicas

Tabela 9.28 - Valores de condutividade térmica de outros materiais

Tabela 10.1 - Cargas máximas aplicadas no ensaio de flexão dos elementos sanduíche (N).201

Tabela 10.2 - Valores encontrados no ensaio do elemento "aparelho de apoio" 205

Tabela 10.3 - Características físicas e químicas do compósito 207

Tabela 10.4 - Valores típicos para o Módulo de elasticidade transversal em função da dureza do elastômero 208

Tabela 10.5 - Módulo de elasticidade transversal em relação ao peso dos blocos de apoio ..209 


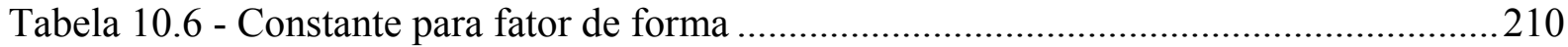


xxxviii 


\section{INTRODUÇÃO}

Diante dos problemas atuais de poluição ambiental, torna-se imprescindível a pesquisa para a busca de alternativas que possibilitem minimizar a degradação do meio ambiente.

Para enfrentar os danos causados pelo impacto ambiental gerado pelos resíduos sólidos, decorrentes de sua disposição final inadequada, vêm sendo adotadas mundialmente, algumas formas de minimização, que incluem o reuso e a reciclagem desses materiais. Medidas voltadas à ampliação do ciclo de vida útil dos bens de consumo, por exemplo, configuram também uma estratégia para atenuar o impacto ao meio ambiente. Estas ações todas têm como meta reduzir a extração de recursos naturais e também maximizar a vida útil dos aterros sanitários.

O presente trabalho visa desenvolver maneiras para solucionar um dos problemas ambientais que afligem a sociedade: a utilização de um resíduo sólido particular que preocupa ambientalistas de vários países.

Neste contexto, a questão dos pneus inservíveis abandonados ou dispostos inadequadamente requer uma atenção especial, pois, além de constituírem um passivo ambiental, ocasionam sérios riscos ao meio ambiente e à saúde pública.

São vários os impactos que os pneus podem causar ao meio ambiente. Quando queimados a céu aberto, liberam dióxido de enxofre na atmosfera, contribuindo para a poluição do ar. Para cada pneu queimado, são liberados cerca de dez litros de óleo no solo, que percolam até atingir o lençol freático, contaminando a água desse subsolo. Quando 
dispostos em aterros sanitários, os pneus, por apresentarem baixa compressibilidade, reduzem a vida útil desses aterros. (CIMINO; BALDOCHI, 2002).

Pelo exposto, verifica-se a necessidade de minimizar esses impactos gerados pelos pneus inservíveis. $\mathrm{O}$ desafio atual para mitigar os danos ambientais causados por estes resíduos no Brasil e no mundo consiste em aplicar as alternativas tecnológicas para fomentar a redução, reutilização e reciclagem dos pneus inservíveis.

Portanto, a presente pesquisa busca apresentar mais uma alternativa tecnológica para utilização deste resíduo na construção civil, auxiliando nas soluções e contribuindo para redução desse passivo ambiental.

\subsection{Justificativa}

Constata-se, no Brasil, que enquanto o aproveitamento de alguns resíduos sólidos evoluiu nas últimas décadas, outros materiais, tais como, pneus inservíveis e demais derivados da borracha, continuam sendo dispostos sem controle no meio ambiente.

O descarte inadequado de pneus inservíveis constitui, atualmente, um dos mais graves problemas ambientais e de saúde pública no contexto urbano.

A proposta do presente trabalho fundamenta-se em nova alternativa tecnológica para minimizar os impactos ambientais gerados por esses pneus, propondo solução inovadora e economicamente viável para atenuar esse passivo ambiental que tanto preocupa os ambientalistas em todo o mundo.

É proposto nesta pesquisa o emprego da resina poliuretana derivada do óleo de mamona para produção de compósitos com o resíduo da borracha de pneu, pois esta resina possui a vantagem de ser um material obtido a partir de recurso natural e renovável, enquanto que a resina poliuretana, proveniente da indústria petroquímica, utiliza compostos derivados 
do petróleo para sua produção, que são recursos esgotáveis, além de algumas de suas formulações serem prejudiciais à saúde.

As resinas poliuretanas são sempre mencionadas como exemplos de materiais que combinam alta resistência mecânica com elevado grau de estiramento antes da ruptura sob tração. Esta combinação de propriedades básicas das poliuretanas leva à combinação de alta resistência ao impacto e abrasão, além de excelente resistência química à maioria dos líquidos orgânicos na forma de fluídos. (ARAÚJO, 1992).

Algumas vantagens podem ser obtidas utilizando as resinas poliuretanas derivadas do óleo da mamona (Ricinus communis), associadas aos resíduos de borracha de pneus, na produção de compostos para a construção civil:

- Redução do volume de resíduos de pneus no meio ambiente;

- Redução na extração de recursos minerais, normalmente utilizados na produção de placas de revestimento e outros produtos manufaturados de borracha sintética;

- Utilização da fonte renovável (resina poliuretana derivada do óleo de mamona) em lugar de derivados da indústria petroquímica;

- Redução do custo dos compósitos produzidos pelo menor consumo de energia na sua fabricação, em relação o processo de produção adotado na regeneração convencional da borracha.

Essa prática demonstra a possibilidade de se associar desenvolvimento tecnológico com desenvolvimento sustentável, por meio de ações que promovam a sustentabilidade, levando à preservação dos recursos naturais e equilibrando o meio ambiente. 


\subsection{Objetivo Geral}

O presente trabalho tem como principal objetivo verificar a viabilidade do emprego da borracha de pneus inservíveis aglomerada com resina PU derivada do óleo de mamona em diferentes aplicações na construção civil, analisando a melhor dosagem borracha-resina poliuretana derivada do óleo de mamona, afim de minimizar os impactos ambientais gerados pelos pneus inservíveis.

\subsection{Objetivos Específicos}

Este trabalho contempla os seguintes tópicos:

- Estudo da distribuição granulométrica mais adequada das partículas de borracha obtida da usina de moagem de pneus inservíveis;

- Análise, por meio de ensaios, da formulação mais viável dos compósitos produzidos com partículas de borracha aglomeradas com resina PU;

- Desenvolvimento do processo e da forma de produção de materiais compostos por borracha e resina poliuretana derivada do óleo de mamona e avaliação da sua possibilidade de aplicação na construção civil;

- Análise de desempenho do compósito por meio de ensaios mecânicos e físicos;

- Produção de componentes e elementos construtivos e avaliação de seu uso potencial na construção civil.

\subsection{Metodologia}

A abordagem metodológica da tese é dividida em oito etapas. 
A primeira etapa consistiu na análise das propriedades físicas de resíduos de pneu

(Figura 1.1), procedida preliminarmente como uma forma para embasar a pesquisa.

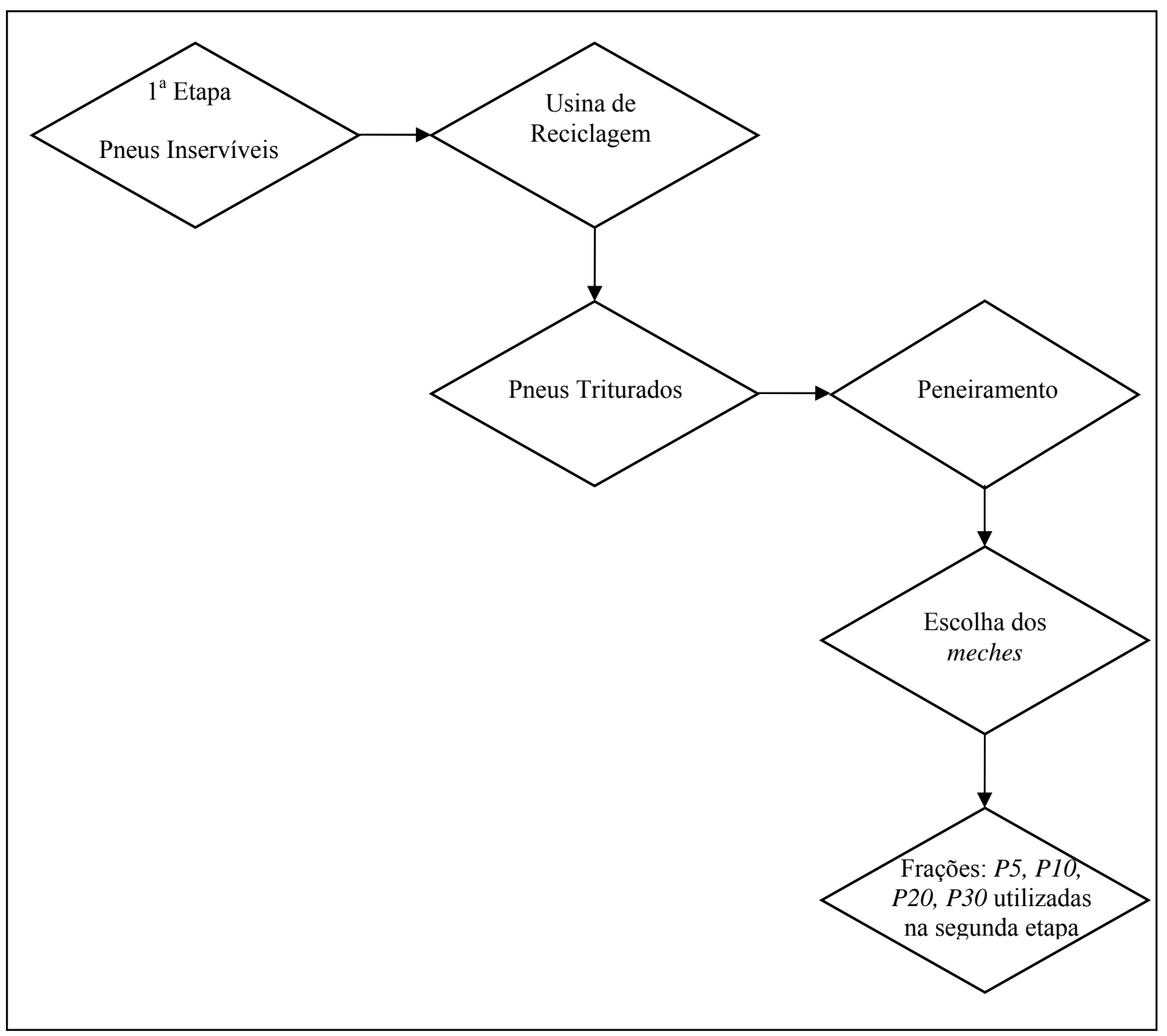

Figura 1.1 - Fluxograma das ações empreendidas na fase inicial ${ }^{1}$

Esta etapa se desenvolveu a partir do processamento que se verifica em unidades fabris para a reciclagem de pneus, tomando-se os materiais decompostos dos pneus originais.

Os pneus inservíveis são encaminhados às unidades de processamento que promovem a desconstrução dos pneus, retirando os talões, triturando a carcaça progressivamente, tornando a borracha disposta em partículas segundo frações granulométricas comercialmente

\footnotetext{
${ }^{1}$ P5, P10, P20 e P30 são as granulometrias comerciais das partículas de borracha após processo de moagem na usina.
} 
estabelecidas pelas peneiras com mesches variando de 5, 10, 20 e 30, números que equivalem a quantidade de tramas das peneiras, por polegada quadrada.

A segunda etapa consistiu na busca do aglomerante e a formulação mais adequada para o resíduo escolhido na primeira etapa.

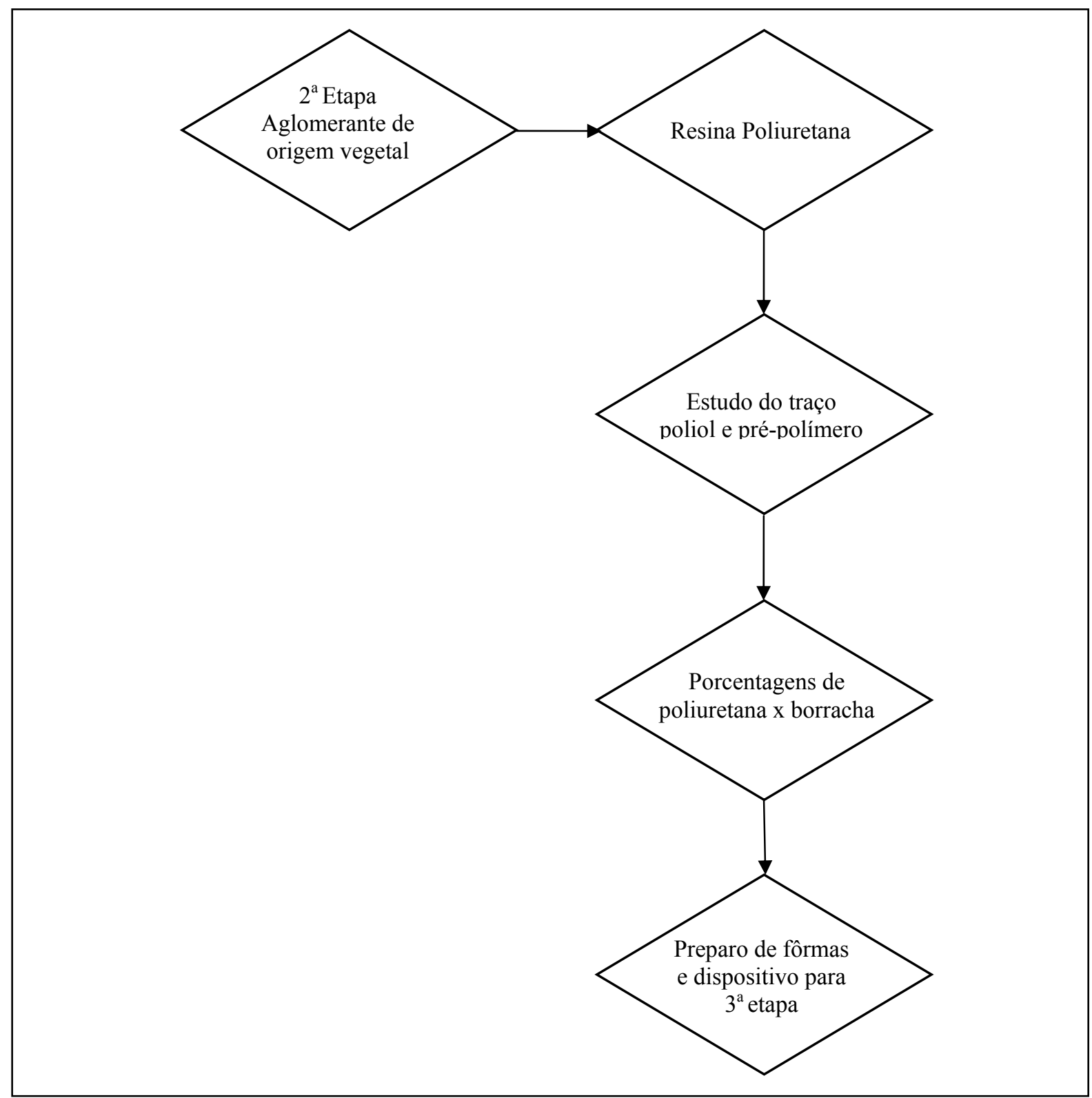

Figura 1.2 - Experiências para a definição do composto constituído a partir dos materiais gerados pela usina de reciclagem de pneus inservíveis

Nesta segunda etapa foram realizados os procedimentos tecnológicos para a constituição do composto: borracha + resina poliuretana de origem vegetal. 
A justificativa para utilização de uma resina de origem vegetal como aglomerante de partículas de borracha, de diferentes dimensões, consiste na busca de produtos alternativos àqueles produzidos pela indústria petroquímica.

Além disso, a presente pesquisa visou a um novo paradigma para a reciclagem de borracha proveniente de pneus inservíveis, e de modo a não envolver processo onde se prioriza a sua desvulcanização, por ser este altamente danoso ao meio ambiente, já que requer em seu processamento quantidades excessivas de energia calorífica e utilização de solventes voláteis que acarretam grande poluição à atmosfera.

Foi desenvolvido nesta fase o estudo do traço mais adequado da resina, ou seja, sua composição poliol : prépolímero que melhor atende às exigências de aderência para as partículas de borracha em meio a matriz polimérica.

Também foram promovidas as análises quanto aos teores resina PU x partículas de borracha que melhor resultado oferecesse para as propriedades requeridas ao compósito.

Nesta fase foi também promovida a adequação e o desenvolvimento de dispositivos visando a produção do compósito.

A terceira etapa consistiu no desenvolvimento de meios adequados para acelerar a polimerização do compósito e a criação de fôrmas para moldagem dos corpos-de-prova, nos diferentes ensaios realizados.

Estes expedientes requereram um grande trabalho para o desenvolvimento das práticas mais adequadas para os compostos estudados.

Diferentes tipos de moldes foram desenvolvidos nesta fase da pesquisa, de maneira a possibilitar a confecção de corpos de prova para serem ensaiados segundo as normas técnicas que regulam as propriedades dos materiais elastoméricos. 
Ensaios para determinação da resistência à tração ou à compressão foram viabilizados mediante adoção de moldes em condições de possibilitar uma adequada moldagem e posterior desforma dos corpos-de-prova.

Aspectos relacionados à estanqueidade dos moldes, facilidades de preenchimento e compactação do material antes de sua polimerização, tempo de catálise e pressão introduzida durante moldagem foram questões amplamente investigadas durante esta fase.

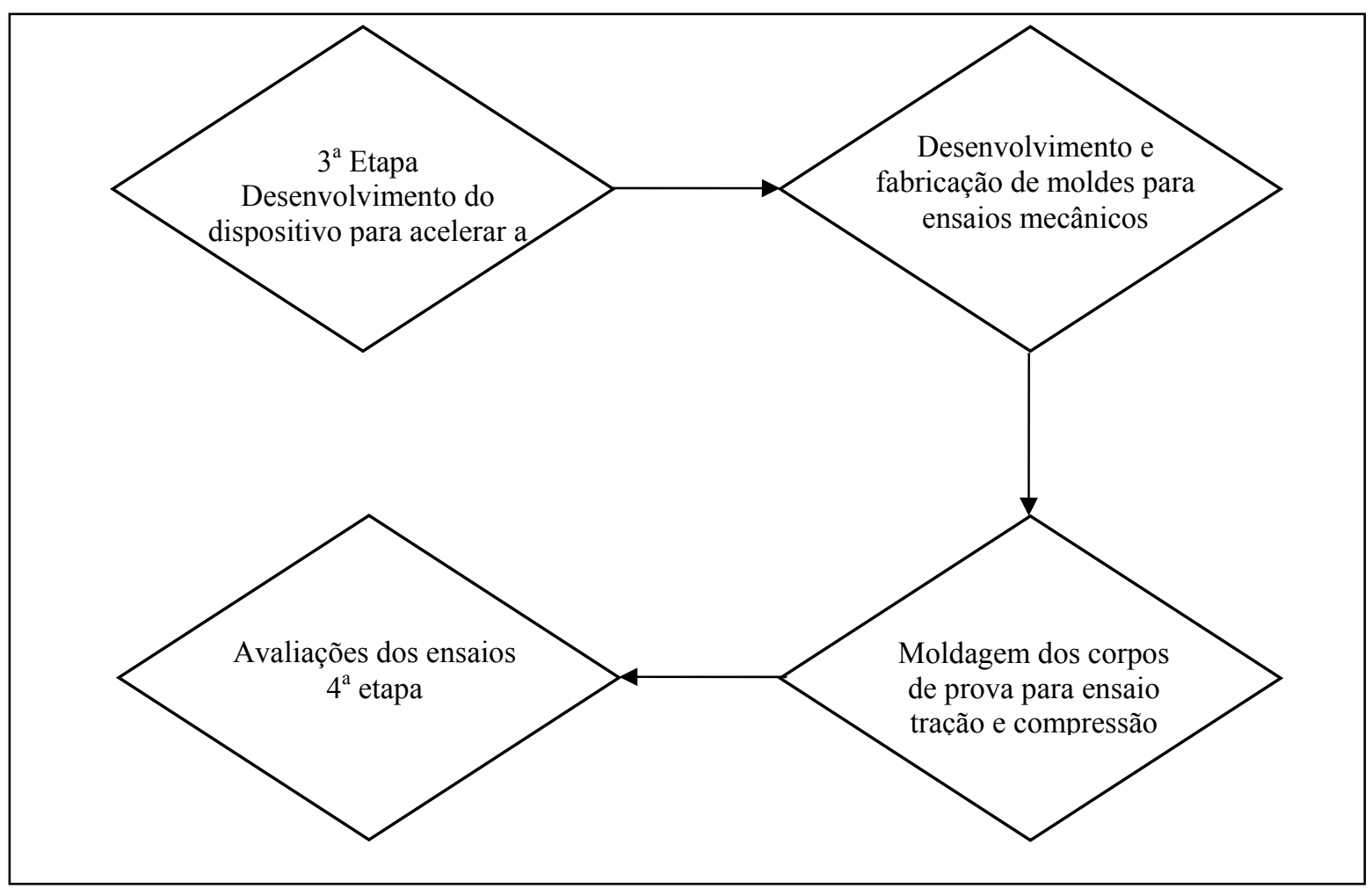

Figura 1.3 - Desenvolvimento de equipamentos para ensaios

A Figura 1.3 exemplifica as atividades empreendidas na etapa de moldagem e polimerização do material composto.

Foi necessário o desenvolvimento de um equipamento capaz de fornecer calor aos moldes e, assim, acelerar a polimerização da resina PU responsável pela aglomeração das partículas de borracha. Um dispositivo específico, constituído por uma resistência elétrica, foi 
construído com essa finalidade, e de maneira a obter uma polimerização termo-catalítica da resina PU, mantendo suas principais propriedades.

Diferentes tipos de produtos desmoldantes, para evitar a aderência no material polimerizado à fôrma, foram empregados nesta fase da pesquisa, até chegar ao mais satisfatório. Grafite em pó, vaselina líquida, películas e filmes plásticos foram algumas das maneiras utilizadas para evitar a aderência do compósito aos moldes metálicos.

A quarta etapa consistiu na caracterização do compósito, segundo suas propriedades físicas e mecânicas.

Os ensaios de microscopia eletrônica permitiram uma análise topológica das partículas de borracha e sua da ligação com a resina PU. O grau de empacotamento dos grãos de borracha ficou visível nestas análises, o que permitiu eleger a melhor composição granulométrica das partículas de borracha, como também a quantidade mais adequada de resina PU utilizada como aglomerante.

Os procedimentos para caracterização dos materiais poliméricos estão mais voltados para os materiais unifásicos, macroscópicamente falando. Isso acarreta algumas dificuldades quando se têm um material composto, como no caso presente, tornando necessárias algumas adequações na condução de alguns ensaios. 


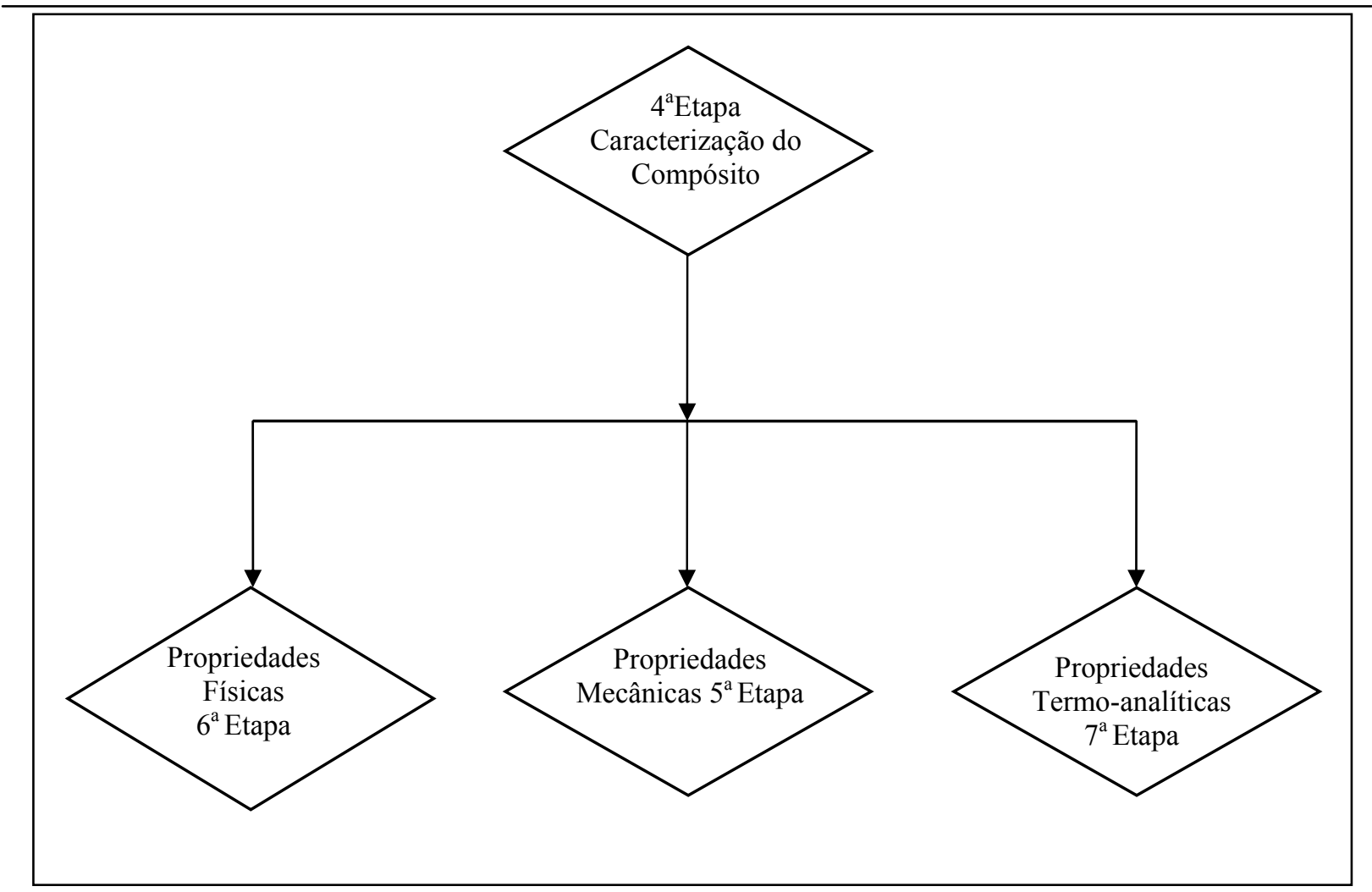

Figura 1.4 - Abordagem metodológica para caracterização do compósito 


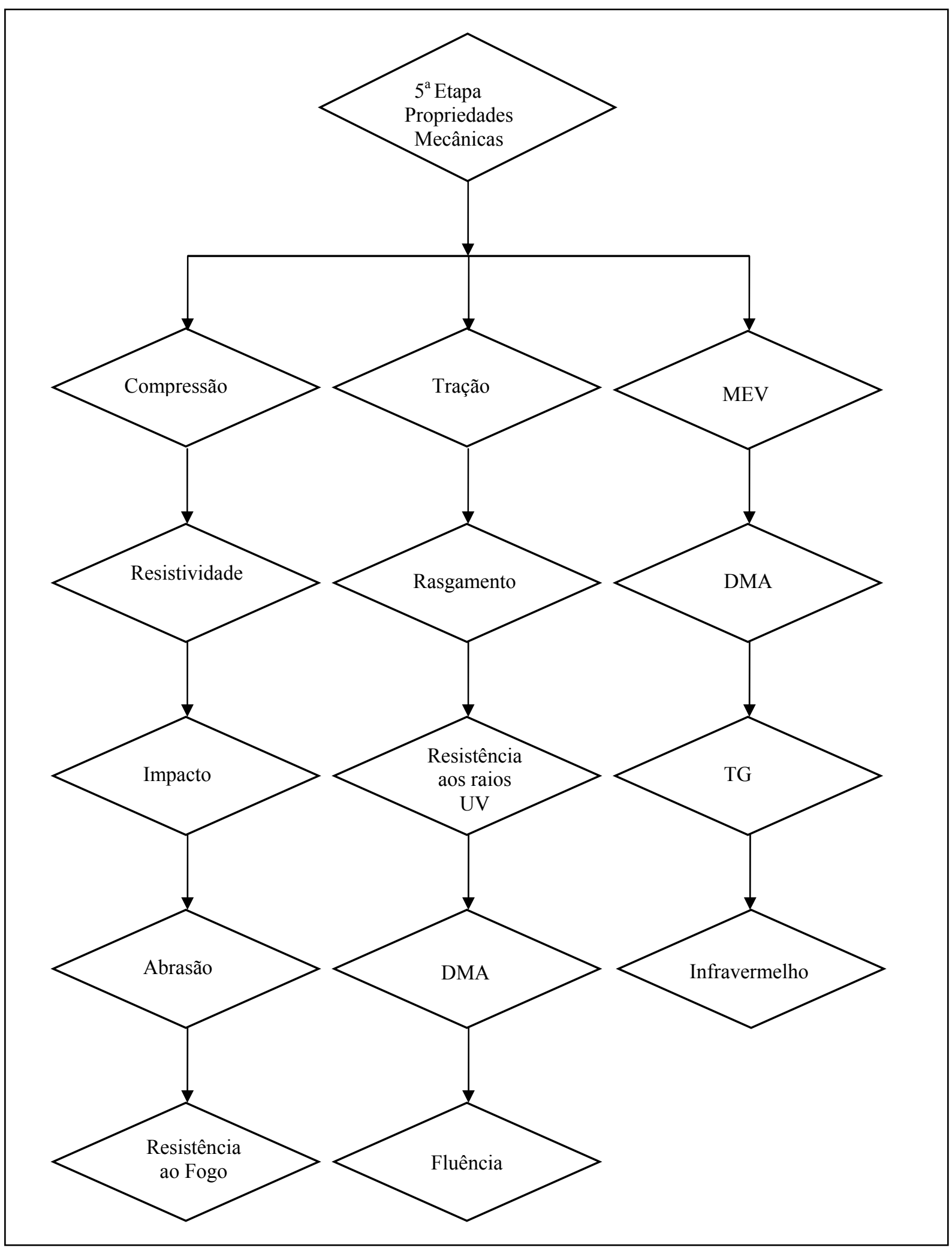

Figura 1.5 - Abordagem metodológica para caracterização das propriedades mecânicas 
A determinação das propriedades mecânicas, principalmente a resistência à tração, foi dificultada em razão da heterogeneidade do material na seção analisada do corpo de prova.

Isso acarretou a necessidade da realização de outros ensaios complementares, para maiores subsídios na detecção das propriedades do compósito, como DMA, por exemplo, o qual permitiu simular as suas propriedades ao longo do tempo por meio da fluência.

Os ensaios de MEV - microscopia eletrônica de varredura, DMA - análise dinânicomecânica, TG - termogravimetria, Infravermelho - espectroscopia na região do infravermelho, e sujeição aos Raios UV - radiação ultravioleta, foram executados como uma forma de análise mais aprofundada das propriedades do compósito. No caso da radiação UV, o compósito tem suas propriedades mecânicas alteradas em função do grau de polimerização da resina PU, condição analisada mais em profundidade nos capítulos 8 e 9 . O ensaio de fluência permite investigar uma importante propriedade do compósito quando este é submetido às solicitações de longa duração. O emprego do DMA permite que a análise da fluência seja procedida em um curto espaço de tempo, no qual as solicitações impostas ao material em estudo são intensificadas pela variação da temperatura e freqüência com que estas ações mecânicas incidem sobre o material. Permite-se desta forma predizer, com antecedência considerável, o tempo de vida útil que o material venha a apresentar sob as condições de exposição em que ficou submetido. 


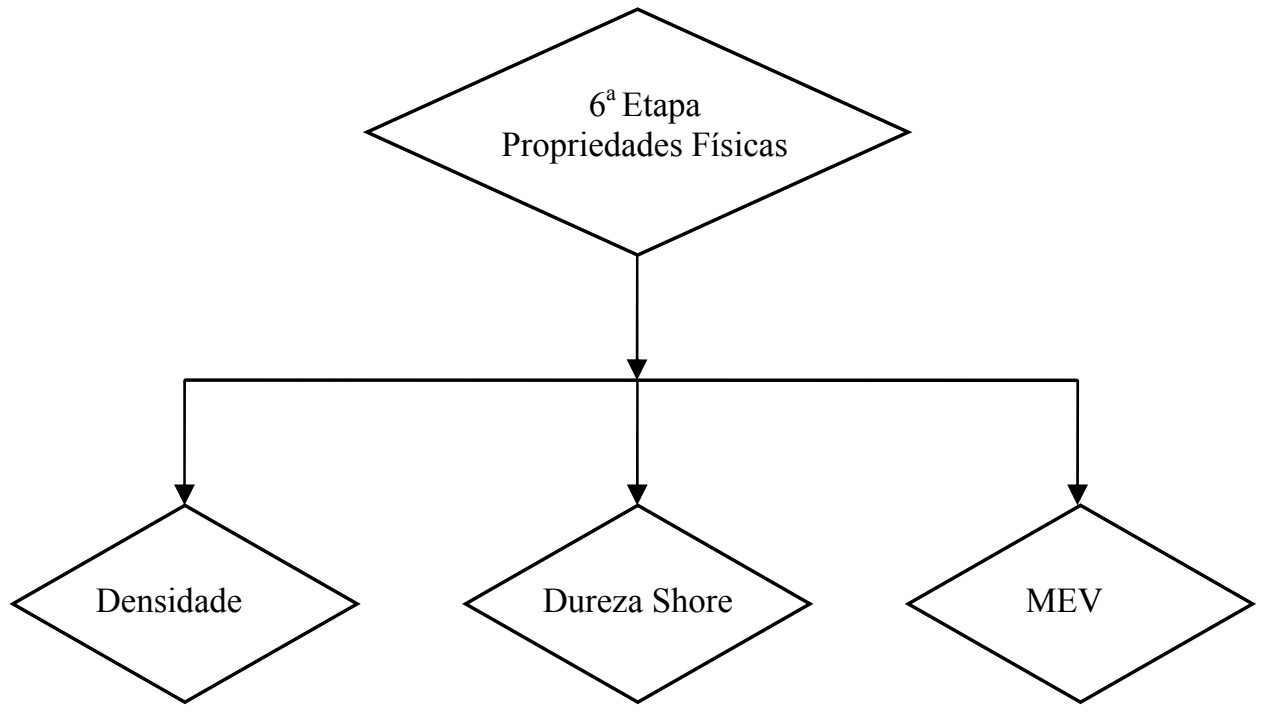

Figura 1.6 - Abordagem metodológica para caracterização das propriedades físicas

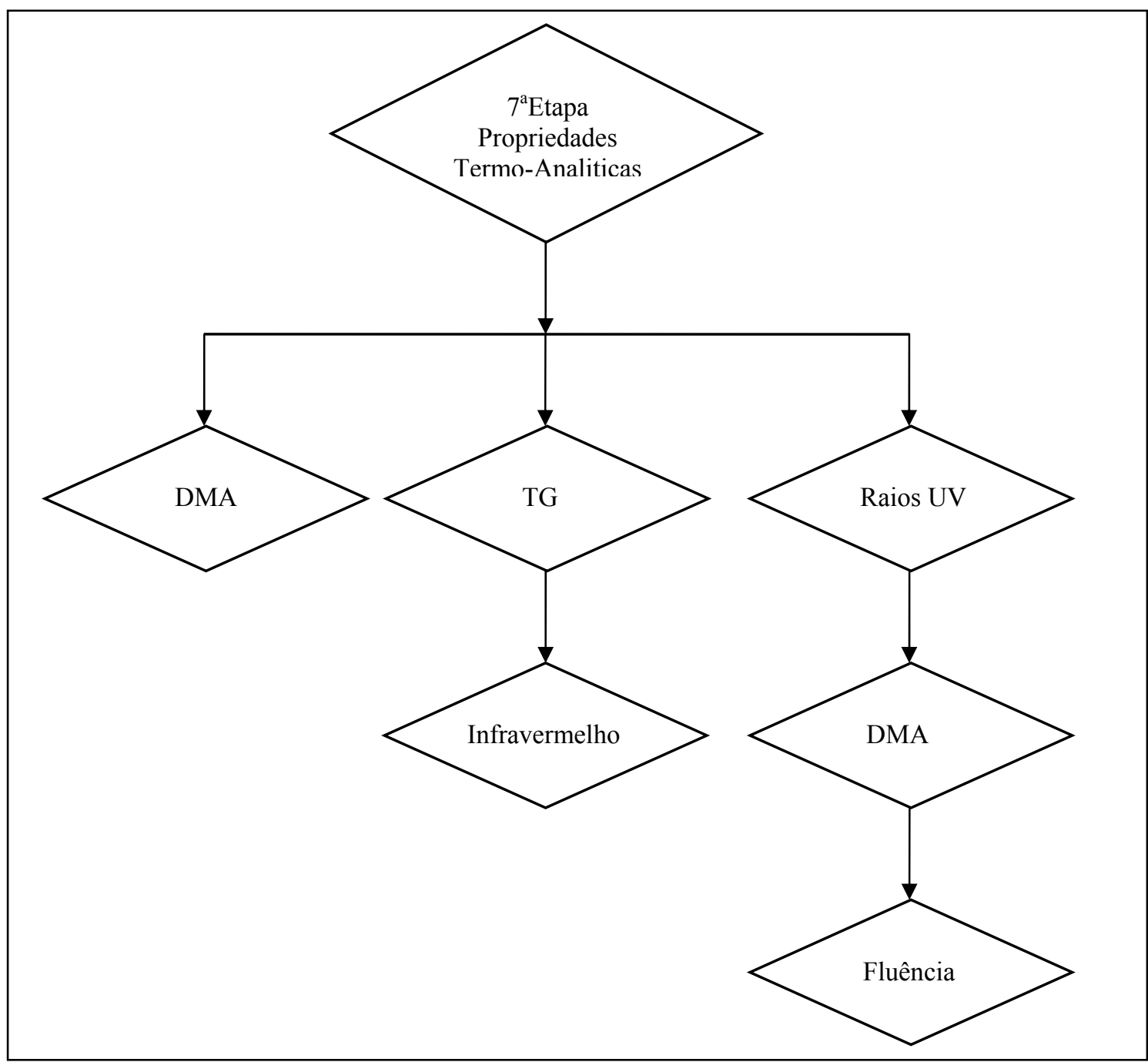

Figura 1.7 - Metodologia para caracterização das propriedades termoanalíticas 
Além destes ensaios realizados com o intuito de analisar as propriedades do material desenvolvido neste trabalho, foram realizados ensaios em componentes produzidos experimentalmente com o compósito, visando avaliar o seu emprego potencial na construção civil. Dentre estas aplicações potenciais está sua aplicação em placas para revestimento de pisos e elementos para uso estrutural, em aparelhos de apoio, por exemplo.

Outras aplicações deste material compósito podem ser intentadas, visando constituir alternativa ao uso de materiais convencionais produzidos a partir de recursos naturais, todavia não foi possível ampliar o número de aplicações desse novo material neste trabalho. Espera-se que isso venha a ser promovido como uma continuidade da pesquisa seja no âmbito da academia, ou por meio do setor produtivo. 


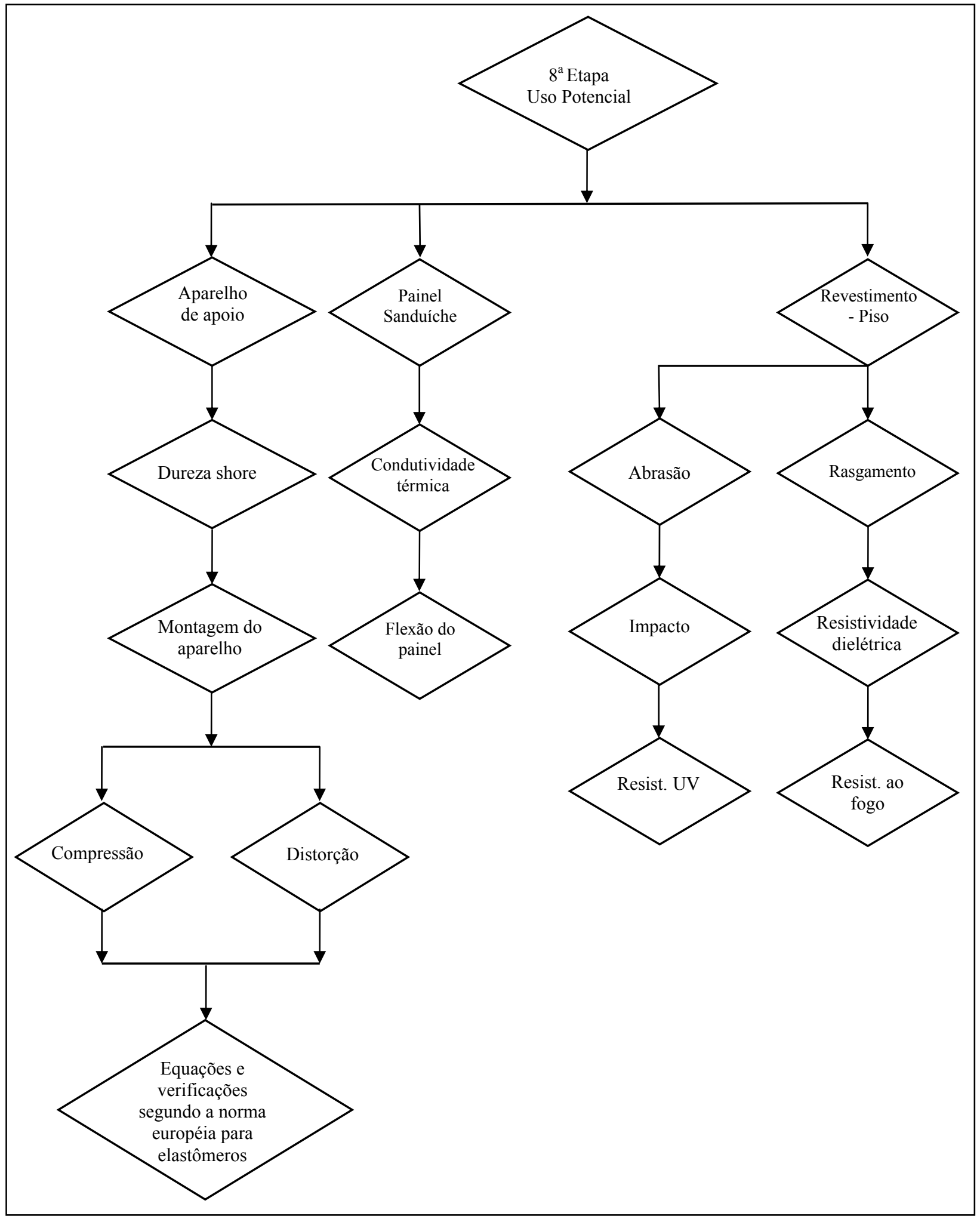

Todos estes ensaios foram procedidos com o intuito de possibilitar a avaliação do compósito da forma mais objetiva visando sua inserção no mercado na construção. Os 
subsídios obtidos com estes ensaios permitem que se tenha uma extensa informação quanto às propriedades e características do compósito, o que favorece a transferência ao setor produtivo.

\subsection{Apresentação da Tese}

A seguir, apresentam-se a ordem e os conteúdos dos capítulos que constituem esta tese:

No Capítulo 2, são apresentadas as considerações iniciais sobre resíduos sólidos.

No Capítulo 3, são apresentadas as características dos pneus, seu processo de produção e o impacto ambiental decorrente de sua disposição inadequada.

No Capítulo 4, são apresentadas as análises e comentários sobre políticas e legislação atuais específicas sobre pneus inservíveis.

No Capítulo 5, são apresentadas soluções para minimização de impactos ambientais gerados por pneus inservíveis.

No Capítulo 6, são apresentados novos procedimentos e tecnologias de redução / reutilização / reciclagem de pneus.

No Capítulo 7, são apresentados conceitos gerais sobre Polímeros, com ênfase na resina PU de origem vegetal e a utilização de resina poliuretana de óleo de mamona em Compósitos.

No Capítulo 8, é procedida a caracterização dos materiais utilizados e os métodos adotados.

No Capítulo 9, estão apresentados os resultados e conclusões parciais dos ensaios efetuados para a caracterização dos materiais.

No Capítulo 10, são apresentadas algumas das utilizações potenciais do compósito. 
No Capítulo11, é apresentada a análise dos resultados e conclusões e sugestões para pesquisas adicionais.

No Capítulo12, são apresentadas as referências bibliográficas.

Nos anexos são apresentadas algumas formulações que servem de fundamentação para assuntos abordados na tese. 


\section{A GERAÇÃO DE RESÍDUOS}

Neste capítulo estão relacionados, de forma sucinta, os diferentes tipos de resíduos sólidos produzidos pela sociedade contemporânea, bem como sua classificação conforme as normas que regulam a sua disposição no meio ambiente.

\subsection{Considerações Iniciais}

Toda atividade humana, seja ela de qualquer natureza, pode ser considerada como promotora de alterações ao meio ambiente, gerando sempre diversos tipos de materiais residuais. O constante crescimento das populações urbanas, a forte industrialização, a melhoria no poder aquisitivo de algumas nações de uma forma geral, vêm promovendo a acelerada geração de grandes volumes de resíduos sólidos, principalmente aglomerados urbanos. (BIDONE, 1999).

De acordo com a NBR 10.004 - Resíduos Sólidos - Classificação, de 1997, da ABNT, a denominação de Resíduo Sólido, do latim residu, significa o que sobra de determinadas substâncias, e sólido é a identificação para diferenciá-lo de líquidos e gases. Resíduos Sólidos são todos aqueles resíduos nos estados sólido e semi-sólido que resultam da atividade da comunidade de origem: industrial, doméstica, hospitalar, comercial, de serviços, de varrição ou agrícola. Incluem-se lodos de ETAS (Estações de Tratamento de Água) e ETES (Estações de Tratamento de Esgotos), resíduos gerados em equipamentos e instalações de controle da 
poluição e líquidos que não podem ser lançados na rede pública de esgotos, em função de suas particularidades. (BIDONE, 1999).

Os resíduos sólidos resultam de atividades industriais, agrícolas e comunitárias e, de acordo com a sua composição, representam um enorme perigo ao ambiente natural. Alguns de seus componentes (borrachas e vidros, por exemplo), ou dificultam, ou tornam praticamente impossível sua decomposição e reintegração de seus elementos na natureza. As figuras 2.1 e 2.2 mostram a composição diversificada dos resíduos sólidos no aterro sanitário do município de São Carlos, e a Figura 2.3 apresenta um lixão a céu aberto, onde pode ser observada a presença de diversos tipos de resíduos: metal, plástico, papel, etc.

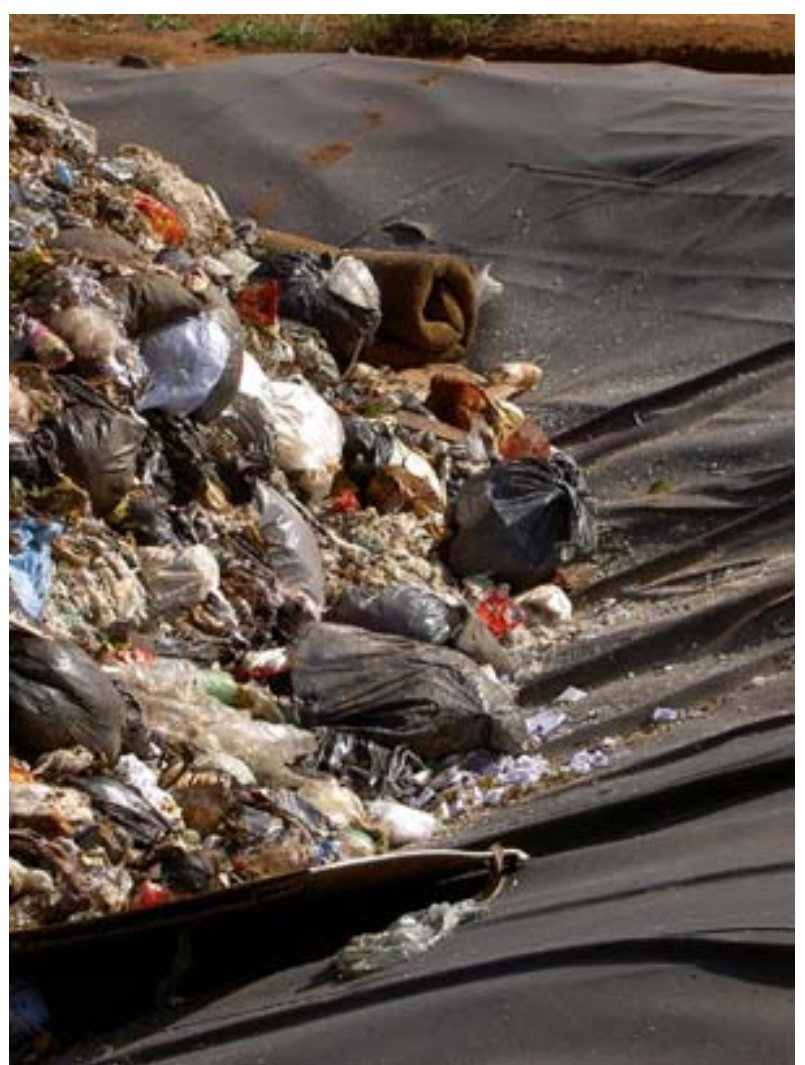

Figura 2.1 - Aterro Sanitário de São Carlos Fonte: Visita Técnica em 06/06/2003 


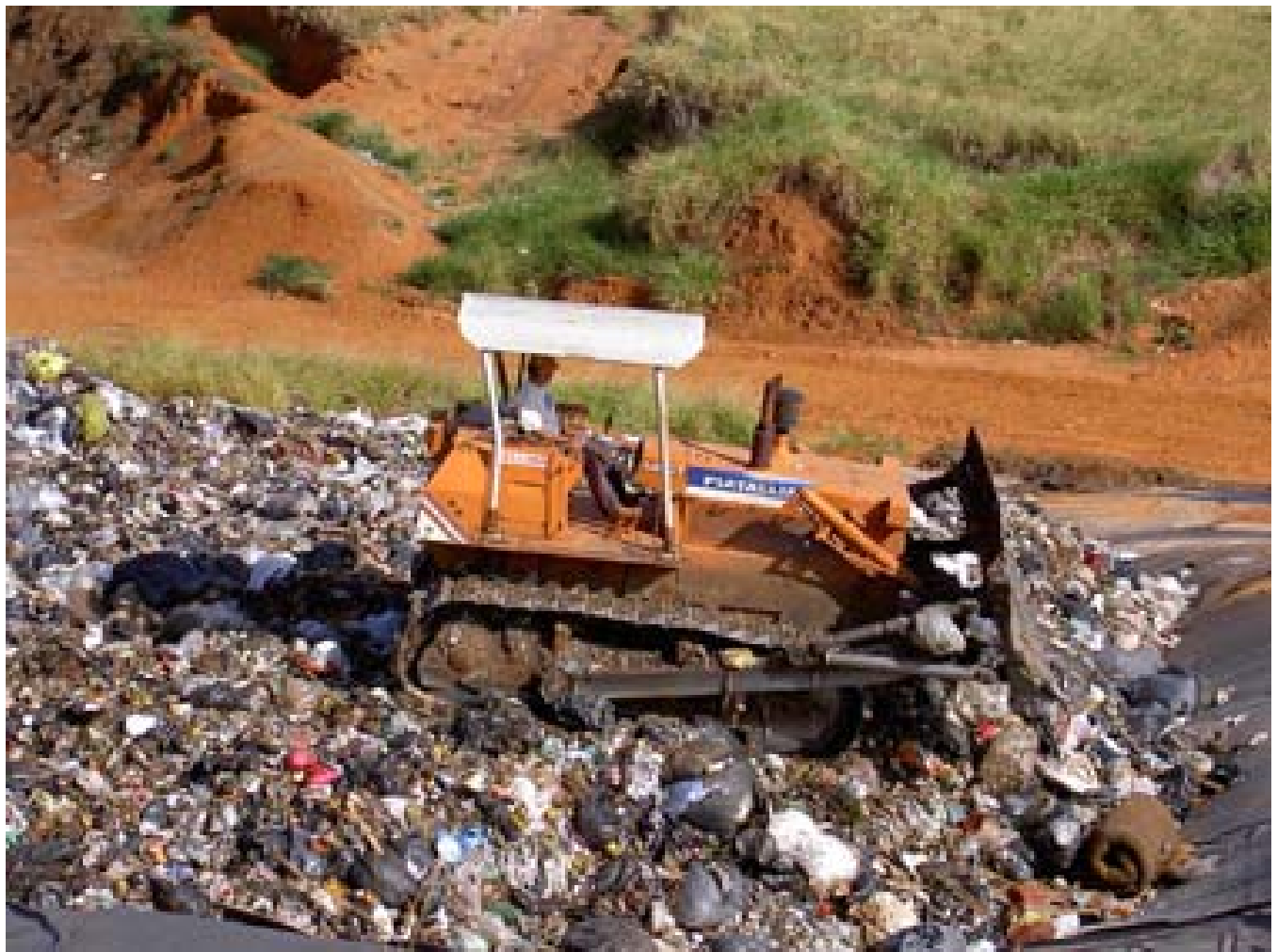

Figura 2.2 - Aterro Sanitário de São Carlos

Fonte: Visita Técnica em 06/06/2003

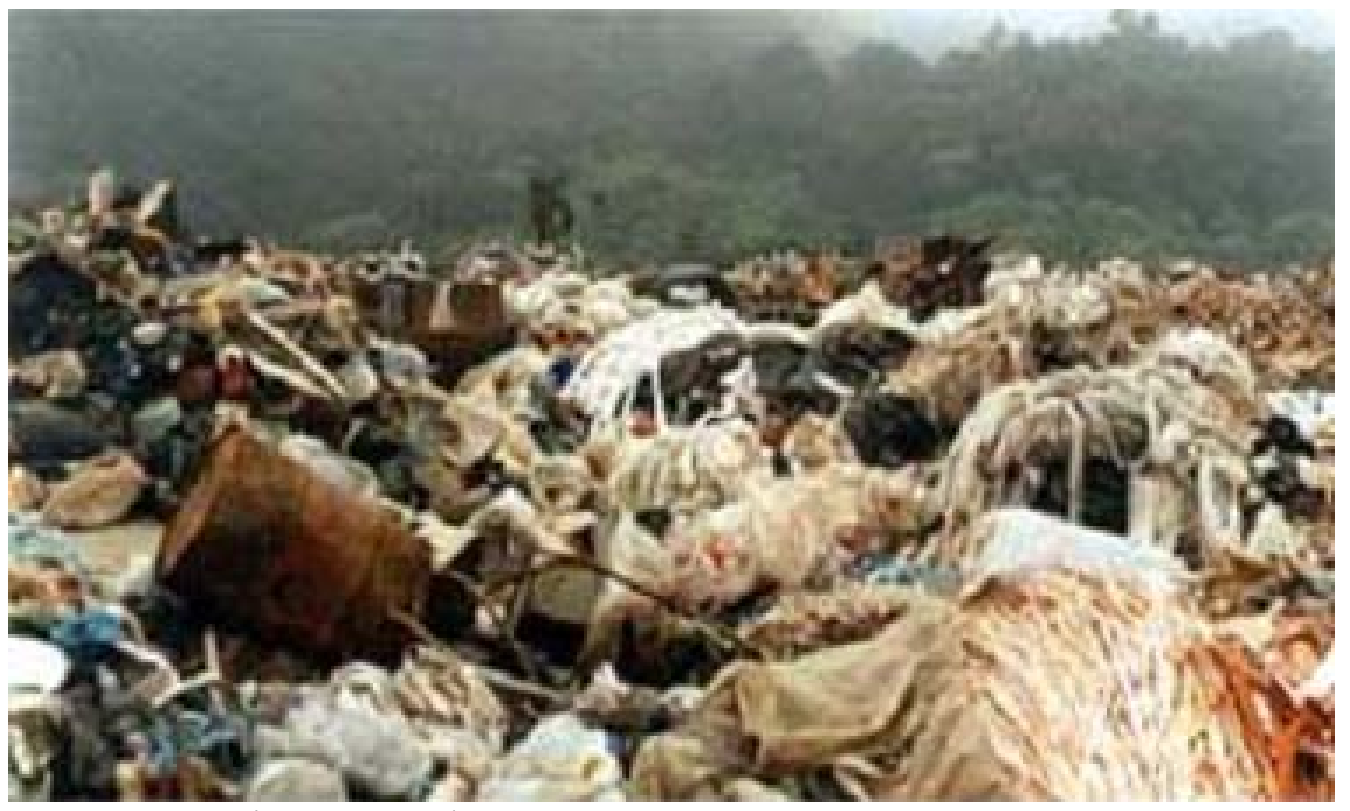

Figura 2.3 - Lixão a céu aberto

Fonte: Visita Técnica em 06/06/2003

A denominação mais técnica dada aos resíduos sólidos é a de "bem pós-utilizado". Segundo Figueiredo (1994), a diferença básica entre a denominação genérica de "resíduo" e a 
de "bem pós-utilizado" está no fato deste último representar um tipo específico de resíduo, que tem sua gênese não como decorrência direta do consumo, mas sim na arbitragem de uma vida útil média estabelecida na própria concepção do produto.

Quando falamos em resíduos, estamos nos referindo, de maneira geral, às embalagens que não possuem utilidade após o consumo de seus produtos, ou aos produtos que não possuem mais serventia por não atenderem mais aos objetivos pelos quais foram criados. Porém, quando nos referimos a bens pós-utilizados estamos falando daqueles produtos feitos para durarem pouco tempo. Assim, vende-se mais, aumentando a produção e os lucros dos setores produtivos e, também, o desperdício de matérias-primas e energia.

\subsection{Classificação dos Resíduos Sólidos Segundo a Origem}

De acordo com a sua origem, os resíduos sólidos podem ser classificados em: (BIDONE, 1999; GOMES, 1989; JARDIM et al., 1995).

a) Residencial ou doméstico: constituído de restos de alimentação, invólucros diversos, varrição, folhagens, ciscos e outros materiais descartados pela população diariamente;

b) Comercial: proveniente de diversos estabelecimentos comerciais, como escritórios, lojas, hotéis, restaurantes, supermercados, quitandas e outros, apresentando mais ou menos os mesmos componentes que os resíduos sólidos domésticos, como papéis, papelão, plásticos, caixas, restos de lavagem, etc.;

c) Industrial: proveniente de diferentes áreas do setor industrial, de constituição muito variada, conforme as matérias-primas empregadas e o processo industrial utilizado;

d) Resíduos de serviços de saúde ou hospitalar: constituído de resíduos das mais diferentes áreas dos estabelecimentos hospitalares: refeitório, cozinha, área de patogênicos, 
administração, limpeza, além de resíduos provenientes de farmácias, laboratórios, postos de saúde, consultórios dentários e clínicas veterinárias;

e) Radioativos: em que se inserem os resíduos de origem atômica, cujo controle / gerenciamento está, de acordo com a Legislação Brasileira, sob tutela do Conselho Nacional de Energia Nuclear (CNEN);

f) Especiais: constituído por resíduos e materiais produzidos esporadicamente como: folhagens de limpeza de jardins, restos de poda de árvores, animais mortos, mobiliários e entulhos;

g) Feiras, varrição e outros: proveniente de varrição regular de ruas, conservação da limpeza de núcleos comerciais, limpeza de feiras, constituindo-se principalmente de papéis, tocos de cigarros, invólucros, restos de capinas, areia, cisco e folhas;

h) De aeroportos, portos, terminais rodoviários e ferroviários: constituem os resíduos sépticos, ou seja, aqueles que contêm ou podem conter germes patogênicos, trazidos aos portos, terminais rodoviários e aeroportos. Basicamente, originam-se de materiais de higiene e restos de alimentação, que podem veicular doenças provenientes de outras cidades, estados ou países. Porém, os resíduos assépticos, nestes locais, são considerados como domiciliares;

i) Agrícolas: em que se agrupam aqueles resultantes dos processos de produção de defensivos agrícolas e suas embalagens.

Entre os fatores que influenciam na produção dos resíduos, segundo Lima (1984), estão: número de habitantes, área de produção, variação sazonal, condições climáticas, hábitos e costumes, nível educacional, poder aquisitivo, tempo de coleta, eficiência do sistema de coleta, disciplina e controle dos pontos produtores, leis e regulamentações específicas, etc.

A norma NBR 10.004 (1987) da ABNT classifica os resíduos sólidos, em três categorias: 
- Resíduos Classe I - Perigosos: Resíduos sólidos ou mistura de resíduos que, em função de suas características de inflamabilidade, corrosividade, reatividade, toxicidade e patogenicidade, podem apresentar riscos à saúde pública, provocando ou contribuindo para um aumento de mortalidade ou incidência de doenças e/ou apresentar efeitos adversos ao meio ambiente, quando manuseados ou dispostos de forma inadequada.

- Resíduos Classe II - Não Inertes: Resíduos sólidos ou mistura de resíduos sólidos que não se enquadram na Classe I (perigosos) ou na Classe III (inertes). Estes resíduos podem ter propriedades, tais como: combustibilidade, biodegradabilidade, ou solubilidade em água.

- Resíduos Classe III - Inertes: Resíduos sólidos ou mistura de resíduos sólidos que, submetidos a testes de solubilização, não tenham nenhum de seus constituintes solubilizados em concentrações superiores aos padrões de potabilidade de águas, excetuando-se os padrões: aspecto, cor, turbidez e sabor. Como exemplo destes materiais, podemos citar rochas, tijolos, vidros e certos plásticos e borrachas que não são decompostos prontamente.

Segundo Gomes (1989) e Bidone (1999), os resíduos sólidos são, também, classificados de acordo com seus diferentes graus de biodegrabilidade, em:

I) Facilmente degradáveis: é o caso de matéria orgânica presente nos resíduos sólidos de origem urbana;

II) Moderadamente degradáveis: papel, papelão e outros produtos celulósicos;

III) Dificilmente degradáveis: trapos, couro (tratado), borracha e madeira;

IV) Não degradáveis: vidro, plástico, pedras, etc.

Os pneumáticos podem ser enquadráveis como produtos cuja vida útil média é consideravelmente baixa, levando-se em conta o período de vida útil do veículo que o contém. Dessa forma, e segundo a proposição de Figueiredo (1994), constituem-se como um "bem pós-utilizado" e, portanto, com elevado potencial para o desenvolvimento de estudos visando redução de seu consumo, sua reutilização, enquanto um produto com outra função a 
desempenhar, e por último, sua reciclagem, dando origem a diferentes tipos de materiais possíveis de serem utilizados em distintos setores da construção civil.

Dentre as classificações constantes da NBR 10.004 (1987), os pneus inservíveis podem ser enquadráveis como Resíduos Classe II - Não Inertes, considerando que apresentam problemas ambientais em função de sua débil biodegradabilidade e sua alta combustibilidade, tornando-se um material de difícil controle após ser submetido ao fogo.

Segundo NBR 10004(2004) os pneus estão classificados como Classe II B inertes código A008. 


\section{PNEUS, PROCESSO DE PRODUÇÃO, DISPOSIÇÃO FINAL E IMPACTO AMBIENTAL}

\subsection{Breve histórico da borracha empregada em pneus}

A história da borracha sintética, segundo Lund (1993), possui o seguinte desenvolvimento:

- Em 1826, Faraday estabeleceu a fórmula empírica da borracha sintética - C5H8;

- Em 1841, o norte americano Charles Goodyear, ao deixar cair uma pequena quantidade de enxofre na seiva aquecida, casualmente, descobre o processo de vulcanização;

- Na Alemanha, mais tarde, começa a ser industrializada a borracha sintética a partir do petróleo;

- Greville Willians isola o Isopreno por destilação seca da borracha natural, em 1860;

- Bouchar Dat, ao aquecer o Isopreno com ácido clorídrico em tubo selado, obtém, em 1879, uma massa semelhante à borracha natural;

- Na Irlanda, em 1887, Dunlop criou o primeiro pneu de bicicleta;

- Em 1897, Euler conseguiu iniciar e completar a síntese da borracha, ao obter, sinteticamente, o Isopreno;

- Em 1895, os irmãos Michelin, pioneiros de uma mega indústria, atualmente mundial, instalaram pneus em automóveis; 
- Na década de 30, após a I Guerra Mundial, os trabalhos de investigação continuaram sendo desenvolvidos, surgindo os Polissulfetos, o Neoprene e as borrachas de Nitrila, capazes de sofrer vulcanização e dar, como produto final, um material parecido com a borracha natural;

- Nas últimas décadas do século passado, foram produzidos novos tipos de borrachas sintéticas, como as de Butila, Silicônica, Silicone Fluorado, Fluoro - Acrílica, Poliuretano Sólido, Polietileno Clorossulfonado e as de Etileno Fluorado, entre outras;

- Na última década foram produzidos: Poliisopreno - elastômero sintético semelhante à borracha; o Polibutadieno; a síntese do Isopreno, por meio de catalizadores estereoespecíficos, e as borrachas de Etileno / Propileno, que seguem os moldes das borrachas naturais.

A borracha natural ganhou o mundo principalmente pela rápida adaptação que sofreu quando, na virada do século, foi plantada com sucesso nas florestas tropicais asiáticas.

Para sua extração são feitos pequenos cortes superficiais no caule da árvore por meio dos quais o látex é captado. Depois de sua coagulação e secagem, este material é aquecido e posteriormente processado com outras substâncias químicas, transformando-se em borracha.

Com o passar do tempo, criou-se na Alemanha a tecnologia para fabricá-la artificialmente a partir do petróleo. Apesar de a borracha sintética ser muito parecida com a borracha natural, ela não é tão resistente ao calor e racha com a mudança de temperatura muito rápida. Por isso, os artefatos são sempre constituídos de uma parcela da borracha natural.

No Brasil, a maior parte da borracha produzida industrialmente é usada na fabricação de pneus, correspondendo aproximadamente a $70 \%$ da produção. Além disso, ela pode ser empregada em calçados, instrumentos cirúrgicos (como tubos, seringas e outros produtos farmacêuticos, além de luvas cirúrgicas e preservativos). 
O pneu é construído como um cilindro sobre um tambor retrátil. Aplicam-se camadas de cordéis impregnados na borracha apropriada, de modo que uma camada amarra os fios metálicos numa direção e a outra camada amarra-os na direção transversal. Os cabos metálicos numa borracha dura e resistente são "costurados" ao pneu mediante a dobragem das extremidades das lonas.

Finalmente, aplica-se a banda formada por extrusão e as extremidades são soldadas. O tambor que forma o pneu é retirado e o pneu cilíndrico é removido e colocado numa prensa; insere-se no cilindro um saco de borracha (usualmente feito de borracha butílica) fixado a uma haste, que é inflado dentro do tubo; simultaneamente o molde da prensa é fechado, e o pneu assume a forma cilíndrica. Aplica-se aquecimento ao molde e vapor ao saco interno. A borracha em excesso escapa por orifícios de drenagem e, depois do tempo de vulcanização a uma temperatura pré-selecionada, o pneu está pronto.

\subsection{Tipificação de Pneus}

A Política Nacional de Meio Ambiente, em seu artigo 94, Subseção X - dos Pneus, bem como o Conselho Nacional de Meio Ambiente, CONAMA, no artigo $2^{\circ}$ da Resolução $n^{\circ}$ 258/99, consideram como:

- pneu: “[...] todo artefato, constituído basicamente por borracha e materiais de reforço utilizados para rodagem de veículos [...]";

- pneu novo: “[...] aquele que nunca foi utilizado para rodagem sob qualquer forma, enquadrando-se, para efeito de importação, no código 4011 da Tarifa Externa Comum - TEC $[\ldots] " ;$

- pneu reformado: "[...] todo pneu que foi submetido a algum tipo de processo industrial com o fim específico de aumentar sua vida útil de rodagem em meios de transporte, 
tais como recapagem, recauchutagem ou remoldagem, enquadrando-se, para efeitos de importação, no código 4012.10 da Tarifa Externa Comum - TEC [...]”;

- pneu inservível: “[...] aquele que não mais se presta a processo de reforma que permita condição de rodagem adicional [...]”.

\subsection{Características dos Pneus}

Os pneus desde 1845 tornaram-se substitutos das rodas de madeira e ferro, usadas em carroças e carruagens. A borracha, além de ser mais resistente e durável, absorve melhor o impacto das rodas com o solo, o que tornou o transporte mais confortável e funcional.

Hoje a maior parte dos pneus é feita de $10 \%$ de borracha natural (látex), $30 \%$ de petróleo (borracha sintética) e 60\% de aço e tecidos (tipo lona), que servem para fortalecer ainda mais a estrutura. Esta estrutura complexa tem como objetivo atribuir-lhe as características necessárias ao seu desempenho e segurança.

Sendo de difícil composição os materiais que compõem a estrutura dos pneus, a sua disposição final torna-se mais complexa. Para que possamos realmente resolver a questão, temos que mudar a ótica de destinação final adequada para melhor tecnologia de tratamento disponível, ambientalmente segura e economicamente viável para os pneus inservíveis. Com esta mudança, poderemos melhor gerir o problema e, por conseguinte, garantir um reuso dos componentes do pneu na cadeia produtiva.

Com 114 anos de criação e um papel insubstituível e fundamental em nossa vida diária, tanto no transporte de passageiros quanto no de cargas, o pneu apresenta uma estrutura complexa, constituída por diferentes materiais, como a borracha, o aço, o tecido de poliéster ou nylon, objetivando conferir as características necessárias para atender as diversas demandas de mercado. (EPA, 1991; D’ALMEIDA; SENA, 2000; BERTOLLO; et al., 1999). 
A tecnologia utilizada, associada ao custo da produção de um pneu, dependerá do mercado, em função de sua destinação geográfica que refletirá o limite de velocidade e as condições das estradas de uma localidade, bem como o estilo de dirigir dessa população. Contudo, com relação à durabilidade, assim como as formas de aproveitamento dos pneus, estes sofrerão influência das diferenças em sua composição, em razão do tipo de veículo onde serão utilizados. (COSTA, 2001).

No que tange à classificação ambiental, trata-se de produto não biodegradável, segundo Lund (1993).

Segundo a NBR 10.004 da Associação Brasileira de Normas Técnicas (ABTN, 1987), o rejeito da borracha é classificado como Resíduo Classe III - inerte, por não conter metais pesados, não sofrer lixiviação e não ser solúvel em água.

Ambientalmente falando, pode-se definir pneus como resíduos sólidos particularmente intratáveis.

Uma vez que não se decompõem, podem desencadear efeitos nocivos e adversos se utilizados em incineradores de resíduos domésticos, podem romper a compactação em aterros e, se empilhados, são ambiente propício para o desenvolvimento de mosquitos e roedores, além de apresentarem risco potencial de incêndio e serem visualmente indesejáveis. A figura 3.1 mostra uma planta de fabricação de pneus. A figura 3.2 mostra as partes que compõem um pneu. 


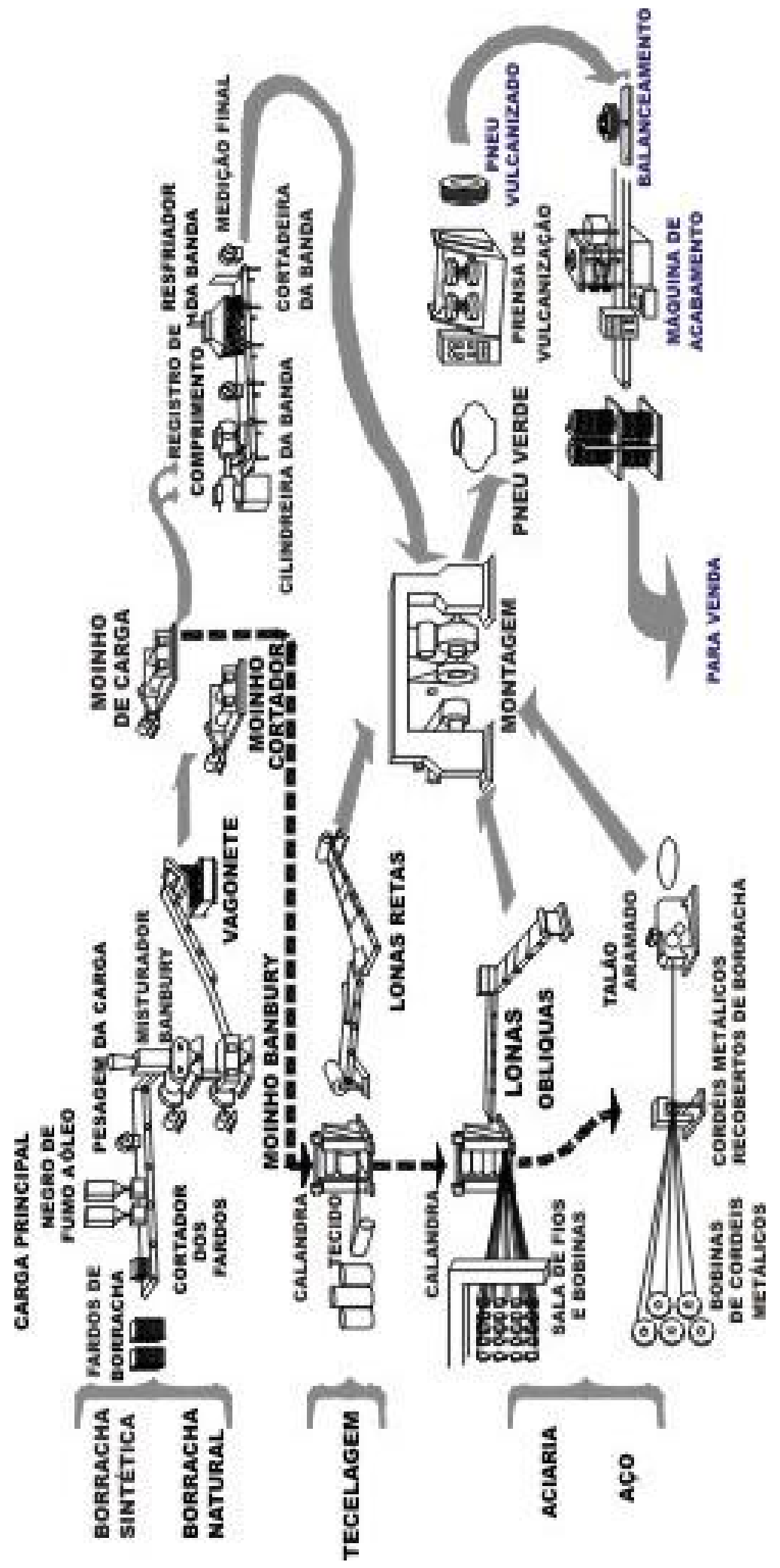

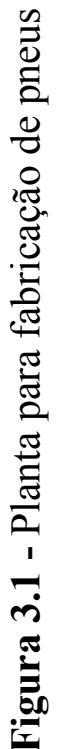




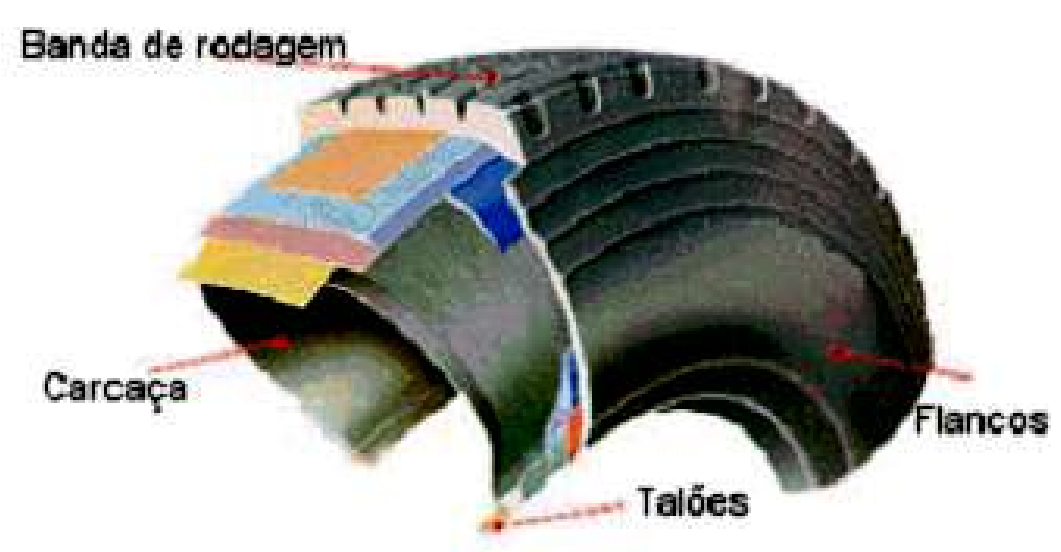

Figura 3.2 - Partes que componentes do pneu

A definição das partes constituintes do pneu é feita da seguinte maneira:

- Carcaça: Parte resistente do pneu que deve resistir à pressão, peso e choques. Compõe-se de lonas de poliéster, nylon ou aço;

- Talões: Constituem-se internamente de arames de aço de grande resistência, tendo por finalidade manter o pneu fixado ao aro da roda;

- Flancos: São as laterais da carcaça, sendo revestidos por uma mistura de borracha com alto grau de flexibilidade e alta resistência à fadiga;

- Cintura: Compreende o feixe de cintas (lonas estabilizadoras) que são dimensionadas para suportar cargas em movimento;

- Banda de Rodagem: Parte do pneu que fica em contato direto com o solo.

Seus desenhos possuem partes cheias chamadas de "biscoitos" e partes vazias conhecidas como "sulcos" e devem oferecer aderência, tração, estabilidade e segurança ao veículo.

Os pneus constituem-se numa fonte de energia por excelência, sendo compostos de borracha natural ou sintética, vários hidrocarbonetos e negro de fumo (conforme pode ser observado na tabela 3.1). Esses componentes perfazem um total aproximado de 85 a $90 \%$ do pneu. O material remanescente é o aço. 
Tabela 3.1 - Composição média do pneu

\begin{tabular}{lc}
\hline COMPONENTES & PORCENTAGEM \\
\hline Negro de Fumo & $28 \%$ \\
Borracha Natural & $14 \%$ \\
Borracha Sintética & $27 \%$ \\
S, ZnO, T102 & $3 \%$ \\
Óleos & $10 \%$ \\
Produtos Petroquímicos & $4 \%$ \\
Fibras & $4 \%$ \\
Cinta de Aço & $10 \%$ \\
\hline
\end{tabular}

Uma análise dos principais constituintes, baseada na composição média de um pneu radial para veículo de passeio, pode revelar seu valor energético:

- Borracha Natural: uma fonte renovável de energia obtida de algumas árvores. O material é retirado sem destruir a árvore.

- Borracha Sintética: produzida a partir do petróleo bruto. Um combustível altamente energético mais limpo que o carvão.

- Negro de Fumo: também produzido a partir do petróleo bruto, sendo um produto com alto valor energético.

- Aço: submetido a altas temperaturas, oxida e produz $3500 \mathrm{Btu} / \mathrm{lb}$. Comparado ao carvão, verifica-se que pneus possuem, em média, maior poder calorífico, mais carbono, menos enxofre e menos umidade. A estrutura do pneu contém reforço em arames de aço. 
Tabela 3.2 - Composição da banda de rodagem de um pneu

\begin{tabular}{lc}
\hline \multicolumn{1}{c}{ COMPONENTES } & PORCENTAGEM \\
\hline Carbono & $83 \%$ \\
Hidrogênio & $7 \%$ \\
Oxigênio & $2,5 \%$ \\
Enxofre & $0,3 \%$ \\
Cinzas & $6 \%$ \\
\hline
\end{tabular}

Além disso, a estrutura do pneu possui um reforço de arame de aço.

Lund (1993) expõe que no processo de produção de pneus, os resíduos da borracha podem ser empregados, novamente, após serem transformados em duas espécies distintas de compostos, a saber:

- recuperado: “[...] é obtido pela simples moagem dos resíduos a pó fino. A borracha contida nos resíduos, por estar vulcanizada, não sofre modificação, não sendo também separada dos outros compostos. Não existe, portanto, uma recuperação da borracha no sentido exato do termo $[\ldots] "$;

- regenerado: “[...] é obtido por meio de vários processos, nos quais os resíduos e os artefatos usados passam por modificações que os tornam mais plásticos e aptos a receber nova vulcanização, embora não tenham as mesmas propriedades da borracha crua, o que significa que não há uma verdadeira regeneração desse material [...]” .

Conforme Lund (1993), o termo "vulcanização" foi proposto por Hans Cock e derivase de Vulcano, antigo Deus Romano do Fogo e dos Vulcões, em razão da presença do enxofre nos vulcões.

Complementa ainda que, “[...] a teoria mais aceita é a de um processo de formação de ligações cruzadas, durante o qual se desenvolve uma estrutura tridimensional a partir das moléculas de polímero individual, nos pontos em que pode ser realizada a reação junto ao agente de vulcanização [...]”. 
Como o enxofre demanda um tempo para se completar, são adicionados à mistura de borracha outros ingredientes - aceleradores e ativadores - para acelerar a reação, reduzindo o tempo e a temperatura necessárias a obtenção de uma borracha com propriedades físicas desejadas.

\subsection{Impactos Ambientais Decorrentes de Disposição Inadequada de Pneus}

O descarte inadequado de pneus inservíveis constitui, atualmente, um dos mais graves problemas ambientais e de saúde pública no contexto urbano.

No Brasil, 100 milhões de pneus velhos estão espalhados em aterros, terrenos baldios (Figura 3.3), rios e lagos, segundo estimativas da Associação Nacional da Indústria de Pneumáticos - ANIP e, a cada ano, dezenas de milhões de pneus novos são fabricados no país (FAPEMIG, 2002).

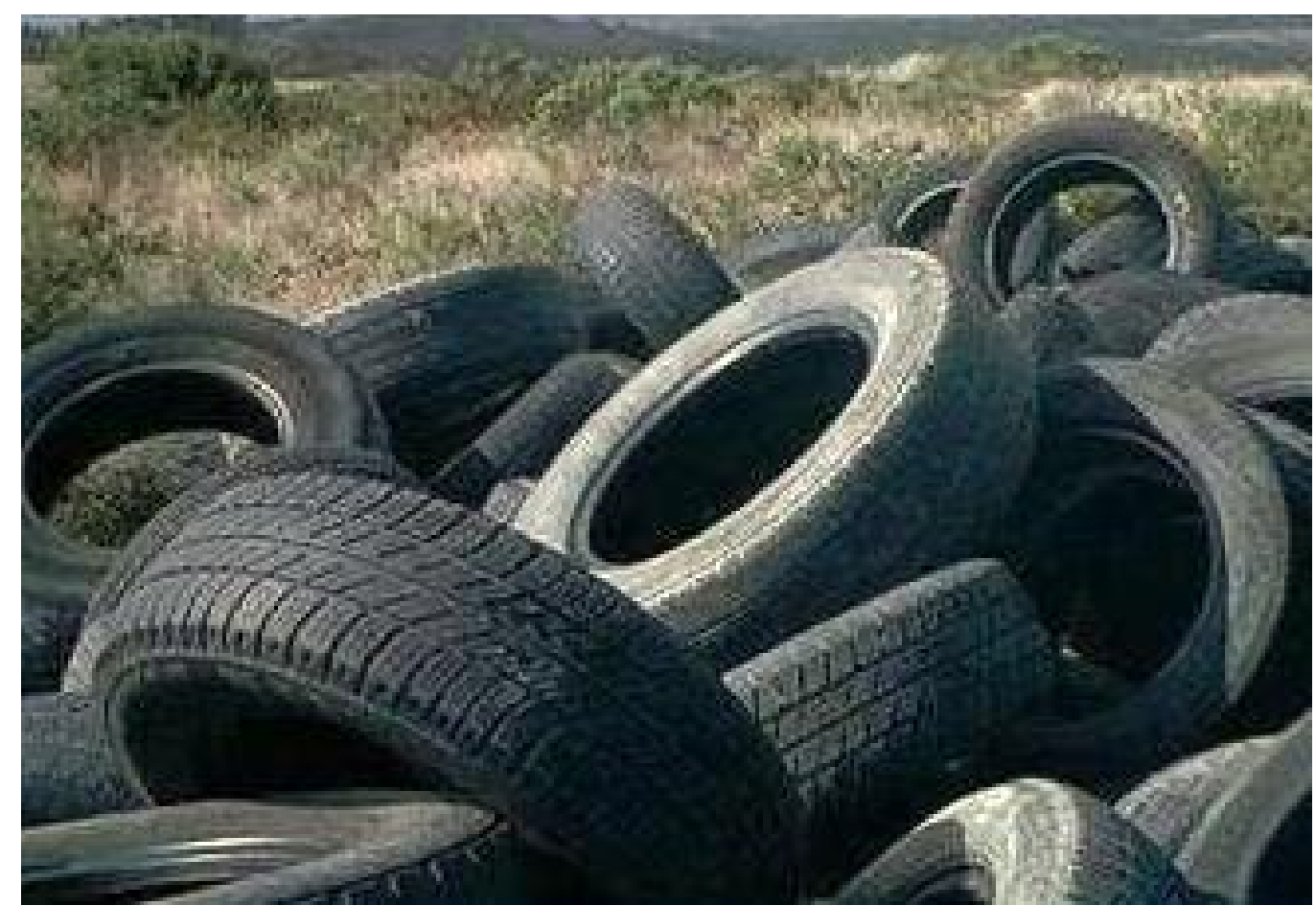

Figura 3.3 - Pneus abandonados

Fonte: http://www.mma.gov.br/ 
Para deter o avanço desse resíduo, é preciso reciclar os pneus de maneira ambientalmente segura. No entanto, a reciclagem dos pneus inservíveis ainda é um desafio, pois a composição da borracha vulcanizada, apresentada anteriormente, confere a este material alta resistência química e física, fazendo da reciclagem um processo complexo e ainda não economicamente atraente para a indústria.

Se admitirmos que a melhor solução consiste em dar tratamento ao resíduo e não simplesmente a sua "destinação final adequada", teremos um maior ganho ambiental para a sociedade e uma série de utilidades para as carcaças de pneus.

Estas, devido a sua composição, podem ser utilizadas em larga escala na construção civil, para usos múltiplos. Elas podem servir para a contenção de encostas, matéria prima para confecção de brinquedos em playgrounds, quebra-mar, recifes artificiais para criação de peixes e para projetos de construção de aterros sanitários que utilizam para a estabilização da manta impermeável uma estrutura de carcaças de pneus amarrados.

Uma utilização que vem sendo cada vez mais incentivada pelo governo dos EUA é o "asfalto modificado com borracha". Esta reciclagem do pneu tem como vantagem principal o aumento da vida útil da estrada e redução do ruído provocado pelo atrito do pneu com o leito carroçável.

O descarte inadequado de pneus inservíveis constitui, atualmente, um dos mais graves problemas ambientais e de saúde pública no contexto urbano, considerando que no Brasil, desde 1939, ano em que teve início a indústria brasileira de pneus até fevereiro de 2001, foi produzida cerca de 860 milhões de pneus, dos quais 45,5 milhões de unidades foram produzidas no ano 2000 .

Echimenco divulgou em 2001 que, de acordo com dados da Unicamp, o Brasil deve ter um total aproximado de 100 milhões de pneus inservíveis abandonados, quer estocados ou deixados a céu aberto, aos quais, anualmente, somam-se cerca de 17 milhões de unidades. 
Esse valor corresponde à estimativa de descarte anual desses inservíveis, que constituem um passivo ambiental, segundo o Conama, em razão de levarem 600 anos para se decomporem.

Com relação ao descarte de pneus, devido ao significativo volume descartado associado a sua grande durabilidade, possui um alto risco de geração de impactos ambientais negativos que necessitam ser mitigados. Este fato motivou a realização de pesquisas em vários países.

Os problemas ambientais decorrentes do descarte de pneus inservíveis estão relacionados aos seguintes fatores:

- O descarte de pneus em corpos d' água que acarretam o assoreamento de rios e lagos;

- Os pneus, por apresentarem baixa compressibilidade, associado a sua degradação muito lenta, ao serem aterrados inteiros, podem provocar o escorregamento das células de lixo, bem como reduzem a vida útil dos aterros; (EPA, 1991; D’ALMEIDA; SENA, 2000; SNYDER apud CIMINO; BADOCHI, 2002).

- Devido a sua forma, se for aterrado inteiro, poderá reter ar e outros gases no seu interior, tornando-se volumoso, e podendo vir a flutuar para superfície, quebrando a cobertura do aterro. Quando isso ocorre, ocasiona a exposição do aterro a micro e macro vetores, à fauna, além de possibilitar que os gases escapem para a atmosfera, bem como haja o vazamento de líquidos; (LUND, 1993)

- A instalação de grandes depósitos que ocupam áreas extensas onde os pneus ficam sujeitos à queima acidental ou provocada, ocasionando prejuízos na qualidade do ar, face à liberação de fumaça contendo alto teor de dióxido de enxofre, entre outras substâncias tóxicas, além de gerar como subproduto, a produção de resíduos oleosos que podem percolar pelo solo, contaminando as águas subterrâneas; (LUND, 1993). 
- Do ponto de vista da saúde pública, o descarte de pneus em terrenos baldios é igualmente danoso, pois face ao seu formato, tende a atrair e reter a água de chuva, bem como absorver a luz do sol, criando um ambiente aquecido e estável. A água estagnada associada às condições de calor geradas, cria um ambiente propício à proliferação de micro e macro vetores, principalmente, em razão de não existirem predadores naturais de mosquitos nesses inservíveis, resultando na proliferação desses insetos, como no caso do mosquito Aedes aegypti, que é transmissor da dengue e da febre amarela; (MELO, 1998).

- Da mesma forma, a armazenagem do pneu em pilhas, dispostas em locais abertos, podem ocasionar problemas de saúde pública descritos no item anterior, bem como estão sujeitos à queima ocasional ou provocada, liberando dióxido de enxofre na atmosfera. (D’ALMEIDA; SENA, 2000).

Várias decisões podem ser tomadas para mitigar os impactos ambientais gerados pelo manuseio inadequado de pneus inservíveis. Estas decisões podem se dar em nível gerencial, operacional ou tecnológico. 


\section{POLÍTICAS E LEGISLAÇÃO ATUAIS SOBRE PNEUS}

\subsection{Política Nacional de Resíduos Sólidos}

A Política Nacional de Resíduos Sólidos, na Subseção X - dos Pneumáticos, estabelece as responsabilidades dos fabricantes e importadores de pneus, atribuindo-lhes o gerenciamento dos respectivos resíduos sólidos gerados, que deverão estar em consonância com o Plano de Gerenciamento de Resíduos Especiais, aprovado pelo Sistema Nacional do Meio Ambiente (SISNAMA).

Além disso, determina que os fabricantes e importadores sejam obrigados a coletar e dar destinação final ambientalmente adequada a esses inservíveis, decorrente de sua utilização no território nacional. Poderão criar centrais de recepção que deverão estar localizadas e instaladas de acordo com normas ambientais, urbanísticas e de uso do solo, visando ao armazenamento temporário para posterior destinação final ambientalmente adequada desses resíduos.

No caso da coleta dos pneus inservíveis, além dos fabricantes e importadores, serão igualmente responsáveis os distribuidores e pontos de vendas, os quais deverão, em conjunto com aqueles, instituírem a mencionada coleta.

No tocante a comercialização dos pneus, só poderá ocorrer se acompanhada de instruções relacionadas à forma de devolução ao fabricante pós uso, ou após serem considerados impróprios à utilização. 
Por meio da Política Nacional de Resíduos Sólidos fica vedado o descarte de pneus inservíveis em aterros sanitários, no mar, em terrenos baldios, margens de vias públicas, cursos d'água e nas praias, bem como a queima desses pneus, exceto para a obtenção de energia, efetuada por métodos insuscetíveis de causar danos à saúde humana, e ambiental.

\subsubsection{Programa Brasileiro de Reciclagem}

O Programa Brasileiro de Reciclagem, do Ministério do Desenvolvimento, Indústria e Comércio (MDIC), de 1999, sugere priorizar os seguintes programas para o gerenciamento de pneumáticos inservíveis, no âmbito federal:

- estudos e equacionamento da reciclagem de pneus no Estado de São Paulo, e estendê-lo para outros estados;

- apoio aos experimentos da indústria de cimento, para a produção de energia;

- armazenamento planejado estratégico de pneus para reciclagem - recomendação feita pela ANIP;

- análise de custo/benefício da importação de pneus usados;

- equiparar o Brasil a outros países, onde são utilizadas melhores formas de reciclagem de pneus do mundo.

Para o gerenciamento do descarte inadequado de pneus, são ainda sugeridas as seguintes ações:

- criação de centrais de armazenamento temporário pelos fabricantes e importadores até o destino final, ambientalmente adequado;

- controle da quantidade descartada e o mercado para seu aproveitamento; 
- impedir armazenamento ao ar livre (risco de promover criadouros de vetores), queima ou descarte em rios ou lagos e ainda orientar o comércio e sucateiros;

- definir mercado para reciclagem e transporte, se possível, compactada (MDIC, 1999).

\subsubsection{Ações da Associação Nacional da Indústria Pneumática(ANIP)}

Segundo dados da Associação Nacional da Indústria Pneumática (ANIP), de 2006, cuja entidade representa os fabricantes de pneus novos instalados no país, a marca de 100 milhões de pneus destinados de forma ambientalmente correta foi atingida em 2005. Essa marca corresponde a aproximadamente 500 mil toneladas de pneus velhos ou inservíveis que foram coletados e destruídos de forma ambientalmente correta.

O programa de coleta e destinação adequada de pneus inservíveis criado pela ANIP foi implantado no ano de 1999 e atinge vários estados do Brasil, desde o Amazonas até o Rio Grande do Sul, passando por capitais como Vitória, São Paulo, Rio de Janeiro e Macapá. Atualmente, a ANIP conta com 172 centrais de coleta de pneus inservíveis, dentre os quais 155 são Ecopontos - fruto de parcerias com a iniciativa privada e com prefeituras de 20 Estados do país, além de mais 17 pontos de coleta e recepção de pneus.

\subsubsection{Resolução CONAMA}

O Governo Federal publicou no Diário Oficial de 2 de dezembro de 1999 a Resolução $\mathrm{n}^{\circ}$ 258, de 26 de agosto de 1999, do Conselho Nacional do Meio Ambiente - CONAMA, que define responsabilidades, prazos e quantidades para coleta, reciclagem e destino final ambientalmente adequado de pneus. 
O teor dessa resolução é muito complexo, por se tratar de material de difícil e dispendiosa reciclagem. Não existe em outros países, paralelo da Resolução no 258 , visto que eles ainda buscam soluções voluntárias. A forma brasileira de solução compulsória parece conduzir a melhores resultados e tende se tornar modelo para o resto do mundo. (TOMMASINI, 2001)

Este é um problema que preocupa todos os países. Os Estados Unidos e Europa procuram encontrar uma solução para ela. No Brasil, as autoridades, por meio da Resolução n ${ }^{\circ} 258$, tornaram a solução compulsória. (D’ ALMEIDA; SENA, 2000).

De acordo com o MMA (2002), em março desse ano, o CONAMA aprovou um novo texto da Resolução $n^{\circ}$ 258/99, reforçando a obrigatoriedade da destinação final adequada para pneus novos importados, e a proibição de importação de pneumáticos usados, conforme as Resoluções 23/96 e 235/98, considerando que o país possui um estoque de 100 milhões dessas unidades, segundo o Ministro do Meio Ambiente à época. Além disso, também passaram a ser considerados como passivo ambiental, os pneus de bicicletas.

Ainda, em relação aos pneus importados cabe:

- À Secretaria de Comércio Exterior, SECEX, a atribuição de informar ao IBAMA, bimestralmente, a relação das empresas e as quantidades de pneus importados;

- Às empresas importadoras comprovarem a destinação final desses inservíveis, junto ao IBAMA.

Dessa forma, o novo texto passa a incluir na redação da Resolução 258/99, os pneus importados, novos ou reformados, inclusive aqueles que acompanham os veículos importados. Há, também, um outro artigo que determina que as mesmas regras passam a serem aplicadas para pneus usados de qualquer natureza, que entrem no país por força de decisão judicial. (LIMA, 2000). 
Fabricantes e importadores de pneus, conforme matéria divulgada no Mídianews (2002), de autoria de Roberto Monteiro, conselheiro do CONAMA, para obterem a licença ambiental tem que comprovar, previamente, junto ao IBAMA, o recolhimento e destinação final ambientalmente adequado de pneumáticos inservíveis. Essa exigência visa impedir que um reciclador não licenciado pelo IBAMA, e que esteja descumprindo seus compromissos ambientais, importe esse produto.

A Resolução considera pneu “todo artefato, inflável, constituído basicamente por borracha e materiais de reforço utilizados para rodagem em veículos". Como pneu novo a Resolução define aquele que nunca foi utilizado para rodagem; como pneu reformado aquele que foi submetido a algum tipo de processo industrial com fim específico de aumentar a sua vida útil de rodagem em meios de transporte; e como pneu inservível aquele que não mais se presta a processo de reforma que permita condição de rodagem adicional.

Conforme Recicloteca (2008), um estudo feito pela Universidade de Vrije, na Holanda, descobriu que diariamente se fabricam em média cerca de dois milhões de novos pneus no mundo. Isto significa uma produção anual de 730 milhões de pneus (janeiro/1999). Ao mesmo tempo, hoje são transformados em sucata 800 milhões de unidades por ano.

No Brasil, no ano de 1993, aproximadamente 0,5\% do lixo urbano brasileiro eram de pneus velhos e fora de uso. Não existe ainda no país nenhuma monitoração do Governo, nem do setor privado, sobre as formas de disposição final dos pneus usados, assim como não há levantamento dos depósitos de pneus abandonados em todo o país. Algumas estimativas indicam que são gerados 35 milhões de carcaças de pneus anualmente e que existem mais de 100 milhões de pneus abandonados em todo o país.

Na maioria das cidades analisadas, o poder público municipal proíbe a entrada dos pneus nos aterros (a figura 4.1 apresenta um exemplo dessa situação), eximindo-se da responsabilidade de coletar e armazenar adequadamente esses resíduos e contribuindo para a 
disposição ilegal em terrenos baldios, rios, etc. esse fato também evidencia o descaso das autoridades em relação à saúde pública, pois os pneus proporcionam ambiente adequado para criação do mosquito transmissor da dengue e de outros vetores de doenças.

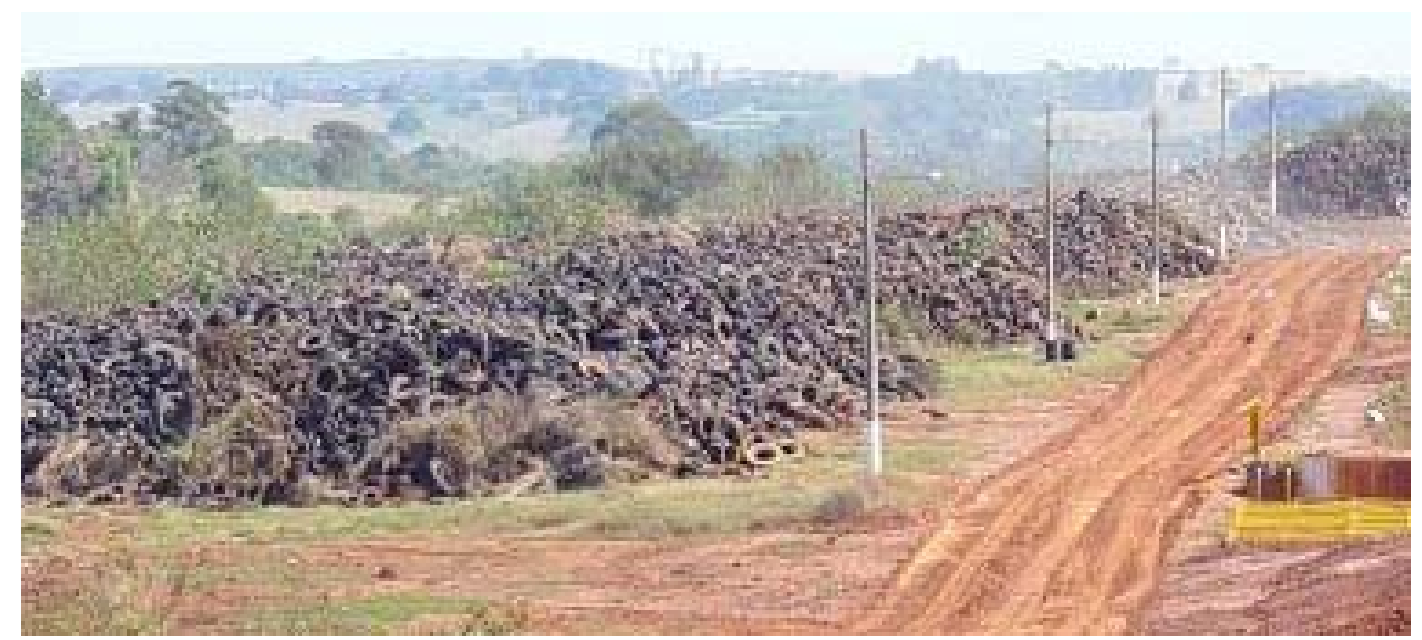

Figura 4.1 - Pneus abandonados

Fonte: Área anexa ao aterro sanitário do município de São José do Rio Preto (Foto Autor).

Entretanto, há controvérsias quanto à disposição final em aterros sanitários ser “inadequada", pois, se os referidos pneus forem cortados em tiras ou em placas, a sua disposição torna-se segura. Tal medida tem como finalidade evitar que as carcaças, quando dispostas inteiras nos aterros, venham a subir e sair para a superfície.

\subsection{Dispositivos sobre Tratamento e Disposição de Pneus}

São inúmeras as possibilidades de tratamento para os pneus, entretanto a Resolução tem como premissa básica para a solução do problema apenas a disposição final adequada do resíduo.

O artigo $1^{\circ}$ é tácito sobre o a concepção da Resolução, literis: “Art. $1^{\circ}$ - As empresas fabricantes e as importadoras de pneus ficam obrigadas a coletar e dar destinação final, ambientalmente adequada, aos pneus inservíveis existentes no território nacional na 
proporção definida nesta Resolução relativamente às quantidades fabricadas e/ou importadas." Vale ressaltar que a Resolução não define o que é destinação final, ambientalmente adequada.

O artigo 10 da Resolução, da maneira que está concebido, reforça o "pensamento pequeno" que permeia este diploma legal em reduzir a solução para o passivo ambiental causado pelos pneus inservíveis no Brasil ao simples ato de dispor adequadamente o resíduo. Diz o artigo: "art. 10 - os fabricantes e os importadores poderão criar centrais de recepção de pneus inservíveis, a serem localizadas e instaladas de acordo com as normas ambientais de demais normas vigentes, para armazenamento temporário e posterior destinação final ambientalmente segura e adequada."

Em relação ao artigo 10 há que se ressaltar que nos EUA, em 23 de setembro de 1999, um depósito de pneus com 7 milhões de carcaças estocadas, localizado na Cidade de Stanislaus, no Estado da Califórnia, pegou fogo. Este incêndio, que ficou descontrolado, lançou uma quantidade enorme de enxofre para a atmosfera, causando um prejuízo irrecuperável para a qualidade do ar na região. Tal fato nos faz ponderar quanto à indicação de estocagem de pneus como destinação final, ambientalmente adequada ao resíduo em questão. (HACKBART; LIMA, 1999).

$\mathrm{O}$ artigo $9^{\circ}$ deixa dúvidas quanto o que fazer com os pneus dentro do espírito de disposição final adequada contido na Resolução, pois o texto proíbe a disposição final em aterros sanitários. Sendo assim, teremos apenas as disposições finais em aterros industriais ou em equipamentos térmicos, tais como incineradores ou fornos de cimento. Diz o artigo: "art. $9^{\circ}$ - A partir da data de publicação desta Resolução, fica proibida a destinação final inadequada de pneus inservíveis, tais como disposição em aterros sanitários, mar, rios, lagos ou riachos, terrenos baldios ou alagadiços, e queima a céu aberto.” 
Ressalta-se que os processos térmicos são tecnicamente considerados tratamentos de resíduos.

\subsection{Disposições sobre o passivo ambiental}

O prazo contido no artigo $3^{\circ}$ da Resolução 258/99, combinado com o artigo 11 , dá a dimensão das questões relativas ao passivo ambiental dos pneus.

Os artigos $3^{\circ}$ e 11 determinam que: “Art. $3^{\circ}$ - Os prazos e quantidades para coleta e destinação final de forma ambientalmente adequada dos pneus inservíveis de que trata esta Resolução são os seguintes":

I - a partir de $1^{\circ}$ de janeiro de 2002, para cada quatro pneus novos fabricados no País ou pneus importados, inclusive aqueles que acompanham os veículos importados, as empresas fabricantes e as importadoras deverão dar destinação final a um pneu inservível;

II - a partir de $1^{\circ}$ de janeiro de 2003, para cada dois pneus novos fabricados no País ou pneus importados, inclusive aqueles que acompanham os veículos importados, as empresas fabricantes e as importadoras deverão dar destinação final a um pneu inservível;

III - a partir de $1^{\circ}$ de janeiro de 2004.

a) para cada pneu novo fabricado no País ou pneu novo importado, inclusive aqueles que acompanham os veículos importados, as empresas fabricantes e as importadoras deverão dar destinação final a um pneu inservível;

b) para cada quatro pneus reformados importado de qualquer tipo, as empresas importadoras deverão dar destinação final a cinco pneus inservíveis.

IV - a partir de $1^{\circ}$ de janeiro de $2005:$ 
a) para cada quatro pneus novos fabricados no País ou pneus novos importados, inclusive aqueles que acompanham os veículos importados, as empresas fabricantes e as importadoras deverão dar destinação final a cinco pneus inservíveis;

b) para cada três pneus reformados importados de qualquer tipo, as empresas importadoras deverão dar destinação final a quatro pneus inservíveis;

Parágrafo único. O disposto neste artigo não se aplica aos pneus exportados ou aos que equipam veículos exportados pelo país.

A íntegra do art. 11 afirma que: "Os distribuidores, os revendedores e os consumidores finais de pneus em articulação com os fabricantes e importadores e Poder Público deverão colaborar na adoção de procedimentos, visando implementar a coleta dos pneus inservíveis existentes no país.”

Adotando-se os dados contidos no "Manual de Gerenciamento Integrado de Lixo Municipal", editado em 1995, pelo IPT, em parceria com o CEMPRE, tem-se que o Brasil gera cerca de 10 milhões de carcaças de pneus por ano. De 1995 até 1999, e desconsiderando o passivo anterior a 1995, já se tem 40 milhões de carcaças; e até o ano de 2002 esse passivo ambiental corresponde a 70 milhões de pneus inservíveis no Brasil. Este passivo ambiental se traduz na cifra de R $\$ 14$ bilhões se os 70 milhões de pneus forem tratados em fornos de cimento a um custo de R\$200,00 por tonelada. (HACKBART; LIMA, 1999).

Pelo texto, contido no artigo 11 da Resolução, este passivo ambiental industrial está sendo dividido, de modo dissimulado, com a sociedade e com o Poder Público, sem contar que o dispositivo apenas determina que a sociedade, em parceria com o Estado e os produtores de pneus, adotem procedimentos, visando a implementar a coleta dos pneus inservíveis existentes no país.

Vale lembrar que nas diretrizes gerais sobre resíduos sólidos da França, decreto N. ${ }^{\circ}$ 92-377/93, bem como da União Européia (91/157/CEE), os pneus são considerados passivo 
ambiental dos fabricantes obedecendo o princípio do "berço ao túmulo" contido nas referida diretrizes.

\subsection{Gestão de Resíduos Sólidos - Pneus}

Segundo Lund (1993), a gestão de resíduos sólidos nos Estados Unidos, no que se refere aos pneus, adota cinco princípios, a saber:

- Princípio do "berço ao túmulo": o setor produtivo é responsável pelo seu produto, até o término do ciclo de vida desse produto;

- Princípio da responsabilidade: o setor produtivo é responsável pelo custo da coleta e disposição final dos resíduos sólidos considerados recicláveis;

- Princípio do direito de saber do cidadão: todo o cidadão tem direito de saber quais são os resíduos gerados no processo produtivo, assim como onde, quem e como é realizado o tratamento destes resíduos;

- Princípio da co-responsabilidade: toda a empresa de tratamento e disposição final de resíduos sólidos será co-responsável pelos resíduos ali tratados, ou dispostos. Caso receba um determinado resíduo, quer seja doméstico, ou industrial, deverá emitir um certificado de aceitação desse resíduo. A finalidade desse certificado é controlar se o setor produtivo industrial está utilizando alguma matéria-prima em sua linha de produção que seja proibida nos EUA;

- Princípio dos "três erres": tem por finalidade instrumentar a mudança de padrão de produção linear insustentável vivenciada pela indústria nacional, em um padrão circular sustentável. Para tal, deve Reduzir, Reusar e Reciclar os resíduos sólidos, quer sejam domésticos, industriais ou hospitalares. 
De acordo com a EPA apud Cimino e Badochi (2002), o Ato Ambiental Nacional da Política Norte-Americana, tem por finalidade:

- "declarar uma política nacional que incentive a harmonia produtiva e agradável entre o homem e o seu ambiente;

- promover esforços que impedirão ou eliminarão os danos ao ambiente e à biosfera e estimularão a saúde e o bem-estar do homem;

- enriquecer a compreensão dos sistemas ecológicos e dos recursos naturais importantes para a nação;

- estabelecer um conselho na qualidade ambiental".

Conforme Heitzman (1992), em 1991, quarenta e quatro estados americanos decretaram leis visando ao controle da disposição final de pneus inservíveis, sendo que a maioria dos estados proibiu a disposição final de pneus inteiros nos aterros, permitindo o descarte desses inservíveis triturados mediante taxas elevadas, que tornaram essa alternativa economicamente proibitiva.

Cabe destacar que a legislação americana confere, também, aos estados, o direito de cobrarem multas altíssimas dos infratores, sendo que na Califórnia está prevista a prisão dos responsáveis.

Atualmente, as leis estaduais americanas regulamentam sobre aquisição, armazenagem e processamento de pneus inservíveis, impõem restrições para armazenagem desses inservíveis em aterros e oferecem incentivos objetivando desenvolvimento de novas alternativas de uso. 


\subsection{Outras Legislações sobre Resíduos Sólidos - Pneus}

\subsubsection{Lei Estadual no 12.493/1999 - Estado do Paraná}

O Ministério Público do Estado do Paraná sancionou a Lei n. 12.493, em 22 de janeiro de 1999, que foi decretada pela Assembléia Legislativa daquele Estado, e a qual estabelecem princípios, procedimentos, normas e critérios referentes à geração, acondicionamento, armazenamento, coleta, transporte, tratamento e destinação final dos resíduos sólidos no Estado do Paraná, visando ao controle da poluição, da contaminação e a minimização de seus impactos ambientais e adota outras providências.

No artigo 11 dessa Lei, as empresas fabricantes e/ou importadoras serão responsáveis pela coleta e reciclagem dos produtos inservíveis, obedecidas às condições e critérios estabelecidos pelo Instituto Ambiental do Paraná (IAP); no artigo 14, ficam proibidas, em todo o território do Estado do Paraná as seguintes formas de destinação de resíduos sólidos, inclusive pneus usados: queima a céu aberto; lançamento em corpos d'água, manguezais, terrenos baldios, redes públicas, poços e cacimbas, mesmo que abandonados; lançamento em redes de drenagem de águas pluviais, de esgotos, de eletricidade, e de telefone; lançamento “in natura" a céu aberto, tanto em áreas urbanas como rurais. Nos parágrafos desse artigo fica estabelecido que:

- o solo e o subsolo somente poderão ser utilizados para armazenamento, acumulação ou disposição final de resíduos sólidos de qualquer natureza, desde que sua disposição seja feita de forma tecnicamente adequada, estabelecida em projetos específicos, obedecida às condições e critérios estabelecidos pelo IAP; 
- a queima de resíduos a céu aberto poderá ser autorizada, pelo IAP, somente em caso de emergência sanitária, reconhecida pela Secretaria de Estado de Saúde ou pela Secretaria de Estado da Agricultura e Abastecimento;

- o lançamento de resíduos em poços desativados poderá ser autorizado mediante as condições e critérios estabelecidos pelo IAP.

\subsubsection{Lei Municipal n. 10.289/1999 - Campinas - Estado de São Paulo}

Em Campinas, no Estado de São Paulo, foi sancionada a Lei Municipal n. 10.289, de 20 de outubro de 1999, que obriga as empresas que comercializam pneus, pilhas e baterias novas à base de metais pesados como cádmio, cromo, zinco ou mercúrio, a possuírem locais seguros para recolhimento dos usados e a fixarem placas com informações sobre os prejuízos causados pelos produtos ao meio ambiente e dá outras providências.

As empresas que comercializam os materiais retro mencionados ficam obrigadas a possuírem locais seguros para recolhimento dos referidos produtos usados, a fim de terem uma destinação, adequada, de maneira a não poluírem ou prejudicarem o meio ambiente, e atendendo as normas técnicas em vigor no país.

Além disso, nos locais de venda, as empresas deverão afixar placas contendo as informações constantes dos anexos desta lei, alertando os consumidores sobre os perigos de jogar tais produtos em locais inadequados e se colocando pronta a receber o produto usado, no atendimento pós uso.

Quanto aos locais de armazenamento do material usado, deverão seguir as normas de segurança estabelecidas pela Prefeitura Municipal de Campinas, obrigando-se a:

- ser compatível com o volume e a segurança do material a ser armazenado; 
- ser coberto e fechado de maneira a impedir que o material se molhe ou receba e acumule água de chuva;

- ter o piso e as paredes impermeáveis e maneira a impedir infiltração; ser sinalizado corretamente, alertando para os riscos do material ali armazenado;

- não possuir sistema de escoamento de água ligado à rede de esgoto ou de águas pluviais.

\subsubsection{Resolução SMA/SS-1/2002 - Estado de São Paulo}

A Resolução SMA/SS-1, publicada no Diário Oficial do Estado de São Paulo, em 5 de março de 2002, estabeleceu normas para a disposição final ambientalmente adequada de pneus em aterros sanitários.

Tratou-se de uma decisão conjunta entre a Secretaria de Meio Ambiente e a Secretaria Estadual de Saúde devido ao surto de dengue no Estado de São Paulo, que vem preocupando tanto as autoridades sanitárias quanto a população.

Por esse motivo, foi autorizada a disposição de pneus inservíveis em aterros sanitários, desde que devidamente retalhados ou triturados e, previamente misturados com resíduos domiciliares, a fim de garantir a estabilidade dos aterros.

Segundo a Cetesb (2002) não existe impedimento para a destinação final desse material em aterros sanitários, desde que observadas as técnicas adequadas de manejo, devido ser classificados como resíduos inerte pela ABNT. Esclareceu, ainda, que a Resolução Estadual, ao exigir a trituração ou retalhamento do pneu inservível, encontrou um meio de reduzir o volume desses resíduos, assim como uma possibilidade destes resíduos não retornarem a superfície dos aterros pela dificuldade de compactação, evitando também, problemas ambientais decorrentes de queima e de saúde pública. 


\section{ALTERNATIVAS PARA MINIMIZAÇÃO DE IMPACTOS}

\subsection{Alternativas para Minimização de Impactos Ambientais Gerados por Pneus}

Os pneus, quando se tornam inservíveis, contribuem para agravar os problemas ambientais. Por esse motivo, programas de reutilização de pneus estão sendo desenvolvidos, com o propósito de recuperar esses materiais, ampliando o seu ciclo de vida e minimizando os impactos ambientais.

Uma das prováveis soluções seria utilizar o processo de reciclagem de pneus inservíveis, cujo intuito consiste na separação dos materiais componentes do pneu, ou seja, borracha, aço e nylon. Porém, ao que tudo indica, o custo elevado de instalação das empresas de reciclagem de pneus desestimula a implantação desta opção.

Segundo o CEMPRE (2005), o Mapa de Reciclagem no Brasil, elaborado em conjunto com o Serviço de Apoio às Micros e Pequenas Empresas (SEBRAE), apresentou o cadastro das cooperativas e empresas que compram, vendem e separam materiais recicláveis de norte a sul do país. A maioria dessas empresas está localizada na região sudeste e os pneus inservíveis são reciclados por 15 empresas.

De acordo com Santos (2002), uma outra opção para reduzir a quantidade de pneus inservíveis seria a crescente utilização do processo de recauchutagem de pneus, processo o qual contribui para o prolongamento da vida útil desse produto, apesar de ser um processo 
finito em razão dos pneus terem uma limitação quanto à aplicação deste processo sem afetar o seu desempenho.

A economia que esse processo traz é significativa para os pneus de transporte, destinados a caminhões, ônibus, tratores e aviões, que são os que apresentam custos mais elevados, acrescido de que nesse segmento, os custos são mais bem monitorados.

De acordo com Lund (1993), os pneus recauchutados podem ser reutilizados com segurança, e esse processo também é conhecido como recapeamento, consistindo na remoção da banda de rodagem desgastada, por meio de raspagem, e na colocação de uma nova banda, que é vulcanizada, a fim de garantir a mesma durabilidade e características de um pneu novo.

A redução na fonte, a reutilização e a reciclagem também são estratégias da técnica de minimização de resíduos que visam não só ampliar o ciclo de vida dos produtos, bem como, ao serem descartados, transformá-los em novos produtos, reinserindo-os no mercado.

O número de pneus gerados no mundo também poderá ser reduzido com a adoção das seguintes ações. (EAUK, 2001):

- reduzindo o número de veículos nas vias;

- reduzindo a distância de viagem;

- melhorando a manutenção de veículos, visando a prevenir trocas desnecessárias de pneus;

- melhorando o processo de manutenção dos pneus;

- aumentando o número de pneus recauchutados;

- assegurando para todos os pneus novos a possibilidade de serem recauchutados.

Na Europa, principalmente Espanha, os pneus vêm sendo estudados com relação a sua disposição sem que afete o meio ambiente. Por este motivo muitos congressos e seminários sobre inovação e aproveitamento de pneus inservíveis vêm sendo realizados todos os anos, e o surgimento de entidades ligadas ao meio ambiente, como por exemplo, o Club Español de los 
Residuos, visa a incentivar a criação e desenvolvimento de métodos capazes de retirar esse material do meio em que vivemos. O continente europeu começou a se conscientizar de que é necessário dar uma solução adequada para os pneus inservíveis, visto que o acúmulo desse tipo de material aumenta a cada ano.

Maganha e Komatsu (1999) apresentaram estimativas quanto à geração de pneus inservíveis, anualmente, de aproximadamente 580 milhões, considerando o número de veículos no mundo, e que cada veículo gere 1-2 pneus inservíveis por ano. Nestas condições a distribuição pode ser feita a seguir²

- Alemanha - 550 mil ton;

- França - 350 mil ton;

- Reino Unido - 290 mil ton;

- Itália -150 mil ton;

- EUA - 240 milhões de pneus;

- Brasil 39 milhões de pneus novos em 1998, sendo:

1. Exportação - 13 milhões;

2. Mercado interno - 26 milhões;

3. Reposição - 17,5 milhões;

4. Montadoras - 8,5 milhões;

5. São Paulo $\cong 40 \%$ das vendas internas.

\subsection{Redução - Reutilização - Reciclagem}

Apesar dos pneus atualmente possuírem o dobro da resistência de 15 anos atrás, as quantidades desses inservíveis continuam a aumentar, em razão das distâncias percorridas a cada ano, bem como devido ao aumento da quantidade de veículos nas ruas. (LUND, 1993).

\footnotetext{
${ }^{2} \mathrm{O}$ pneu inservível de automóvel tem aproximadamente $3,5 \mathrm{~kg}$ e de caminhão $40 \mathrm{~kg}$.
} 
O volume total de pneus inservíveis nos Estados Unidos atingia 3 bilhões de unidades, em 1993, segundo Lund (1993), sendo que a geração anual desses inservíveis é de 275 milhões de unidades, dos quais mais de 14 milhões de pneus são, anualmente, recuperados por borracheiros.

A produção brasileira de pneus, no ano de 2000, atingiu 45,8 milhões de unidades, segundo CEMPRE (2002), sendo que anualmente, são exportados para 85 países um terço do volume de pneus produzidos no país, e o restante roda em veículos nacionais.

Informam, ainda, que a quantidade de pneus recuperados por "carcaceiros" atinge mais de 21 milhões de unidades por ano, o que significa que a recauchutagem atinge $70 \%$ da frota nacional de transporte de carga e passageiros.

Ressaltam também, que se estima haver no território nacional 500 mil pneus para serem utilizados como combustível o que representaria uma economia de 12 mil toneladas de óleo, considerando que cada pneu contém a energia de 9,4 litros de petróleo.

No período de oito anos, compreendido entre 1985 e 1993, o mercado norte americano de reaproveitamento de pneus inservíveis teve um drástico aumento, sendo que os setores que mais se destacaram, com relação a utilização desse material, foram: áreas de lazer e esporte, construção civil e combustível.

No caso do setor de combustível, trata-se do TDF (Tyred Diesel Fuel), combustível derivado de pneu, que é o produto dominante do processamento de pneus inservíveis nos Estados Unidos por competir em preço com outros combustíveis industriais para caldeiras, embora esse valor dependa da capacidade de processamento e da demanda desse produto.

$\mathrm{Na}$ esfera municipal, dar o adequado destino final aos milhares de pneus inservíveis descartados no ambiente urbano é um dos aspectos de fácil sensibilização desse problema, face às dimensões dos impactos gerados por esses resíduos. 
No que se refere à tecnologia de reutilização, já existem várias opções tanto para reciclagem quanto para reuso dos pneus descartados.

\subsubsection{Redução na Fonte}

Há uma grande diferença entre tratar o resíduo e em coletar e dar destinação final adequada. $\mathrm{O}$ tratamento consiste em se adotar técnicas que visem a reduzir o volume dos resíduos em sua massa e quantidade, minimizar sua periculosidade e/ou inertizá-lo antes de sua disposição final adequada. O programa de minimização de resíduos consiste em reduzir a geração de resíduos na sua fonte geradora por meio de técnicas que levem a empresa fabricante a adotar as seguintes mudanças em sua linha de produção (HACKBART; LIMA, 1999):

- alteração dos materiais utilizados;

- alteração tecnológica no processo produtivo;

- mudanças nos procedimentos operacionais;

- substituição de produtos auxiliares, tais como solventes e agregantes;

- reuso de material ;

- reciclagem.

Uma forma de se reduzir o volume dos pneus inservíveis é ampliando a vida útil dos pneus, por meio de melhoria das técnicas de manufatura, quando de sua produção. Isso possibilita que a média da vida útil do pneu seja duplicada, segundo EPA (1991). 


\subsubsection{Reutilização de Pneus}

Há que se ressaltar que a Política Nacional de Resíduos Sólidos proíbe, segundo o MMA: o descarte desse resíduo sólido nos aterros sanitários, bem como no mar, em terrenos baldios, margens de vias públicas, em cursos d'água e nas praias; e, a queima desses resíduos sólidos, exceto destinados a obtenção de energia, efetuada por métodos insuscetíveis de causar danos à saúde humana ou ao meio ambiente, face a queima de pneus a céu aberto, ocasionarem problemas ambientais mais sérios.

Por esse motivo, programas de reutilização de pneus estão sendo desenvolvidos, com o propósito de recuperar esses materiais, ampliando o seu ciclo de vida e minimizando os impactos ambientais.

\subsubsection{Recauchutagem}

De acordo com Santos (2002), o processo de recauchutagem de pneus contribui para o prolongamento da vida útil desse produto, apesar de ser um processo finito em razão dos pneus terem uma limitação, em relação a esse processo, após o que se tornam inservíveis.

No processo de recauchutagem de pneus, as bandas de rodagem dos pneus tornam-se resíduos. Desta maneira, conclui-se que a recauchutagem de pneus, que no Brasil atinge aproximadamente $70 \%$ da frota de transporte de carga de passageiros, é uma fonte que contribui em grande número para o acúmulo dos resíduos de borracha vulcanizada em forma de grânulos ou cavacos, que é danoso ao meio ambiente, não podendo ser disposto ao ar livre nem enterrado.

Segundo Lund (1993), os pneus podem ser reutilizados com segurança, após serem recauchutados, cujo processo também é conhecido como recapeamento, consistindo na 
remoção da banda de rodagem desgastada, por meio de raspagem, e na colocação de uma nova banda, que é vulcanizada, a fim de garantir a mesma durabilidade e características de um pneu novo.

Contudo, é um processo limitado, devido ao pneu ter condição de ser submetido a esse processo, apenas de 3 a 5 vezes, sem afetar o seu desempenho. (D'ALMEIDA; SENA, 2000).

A economia que esse processo traz torna-se significativa para os pneus de transporte, destinados a caminhões, ônibus e avião, que são mais caros, acrescido de que nesse segmento os custos são melhor monitorados.

Todavia, nos Estados Unidos, para os automóveis a vantagem não é a mesma, face os pneus novos importados serem comercializados a preços mais baixos, fazendo com que os pneus recapeados atendam, prioritariamente, a demanda do setor público. (LUND, 1993).

Com a evolução tecnológica do processo de recauchutagem, surge a remanufatura, que permite não só a substituição das paredes laterais e frontais, como também das porções metálicas.

Esse fato alavancou o aprimoramento dos sistemas, possibilitou a melhoria dos produtos, e a busca de um diferencial e de qualidade, gerando uma grande concorrência entre os fabricantes de artefatos e bandas de borracha utilizados na reforma de pneus, obrigando-os a buscarem novas tecnologias para esse processo.

Lund (1993) expõe que esse processo vem sendo utilizado nos Estados Unidos, desde 1915, visando a ampliar a vida útil da capa dos pneus em $40 \%$, além de economizar $80 \%$ de energia e matéria-prima, com relação a produção de novos pneus, tendo em vista que são consumidos 87 litros de petróleo, na produção de um novo pneu, contra 20 litros utilizados para uma reforma.

Outro fator significativo é que a indústria americana não consegue atender a demanda de produção atual de pneus para o transporte, em razão de produzir 4 milhões desses pneus ao 
ano, contra 9 milhões que, anualmente, são reformados. No total, anualmente, nos Estados Unidos são recauchutados em torno de 38 milhões de pneus. (LUND, 1993).

O Japão é considerado o país que possuí o maior percentual de aproveitamento de pneus, sendo que 93\% do volume total desses resíduos é destinado à recauchutagem e a exportação de pneus meia vida. (SANTOS apud CIMINO; BADOCHI, 2002).

O processo de recauchutagem de pneus é mecânico, realizado através de raspagem das bandas de rodagem dos pneus (de onde se originam os resíduos de borracha), geralmente a raspagem é feita com dois cilindros ranhurados. Esse processo de reconstrução de pneumáticos pode ser dividido em cinco etapas, nas quais são executadas em máquinas e equipamentos de alta tecnologia:

- Inspeção da Carcaça: Etapa determinante para o sucesso da reconstrução, seu propósito é detectar avarias e a qualidade da carcaça;

- Raspagem: Consiste em remover a borracha remanescente da banda de rodagem, configurando a carcaça no diâmetro, contorno e textura adequados;

- Reparação: Todas as avarias detectadas nas carcaças, causadas quando de sua utilização, são reparadas através de escariações;

- Aplicação do Anel: Centralização e roletagem do anel são realizadas por máquina computadorizada, com eficiência e precisão, acomodando o anel sem tensões ou deformações, permitindo assim, harmonia entre banda de rodagem e carcaça, proporcionando balanceamento e acabamento perfeitos;

- Vulcanização: É processada em autoclave automatizado, permitindo aderência perfeita dos anéis às carcaças. Os fatores "tempo", "temperatura" e "pressão" que são fundamentais para preservação da estrutura original das carcaças, são controlados com eficiência e precisão. 
Realizado esse processo, é executada uma inspeção final nos pneus obedecendo aos padrões técnicos, proporcionando segurança, garantia e alta performance.

\subsubsection{Resíduos de Recauchutagem}

No Brasil, os resíduos da recauchutagem de pneus têm sido descartados sem nenhum controle, fato que contribui para aumentar a poluição ambiental e favorecer a proliferação de insetos causadores de doenças.

Outro problema é o elevado risco de incêndio, que é agravado pela dificuldade de extinguir o fogo da borracha dos pneus, que tem em sua composição uma grande quantidade de derivados de petróleo. De acordo com Maganha e Komatsu (1999), o termo "queima de resíduos de pneus" traz a nossa mente imagens de grandes nuvens de fumaça negra e odores ofensivos, sendo que essa queima gera vários produtos da combustão nocivos à saúde, razão pela qual também não se recomenda a sua incineração. Porém, as evidências têm mostrado que pneus podem ser queimados como combustíveis auxiliares quando existem equipamentos de controle de poluição apropriados para controlar as emissões geradas no processo de utilização desses resíduos.

Quanto à disposição dos resíduos de borracha, ela é considerada bastante problemática, uma vez que são muito resistentes à degradação que pode durar até 240 anos, sendo assim incompatíveis com aterros sanitários. Além disso, o crescimento da consciência ecológica no mundo tem feito que se torne inaceitável pela sociedade atual a disposição de resíduos em aterros sanitários.

Maganha e Komatsu (1999) afirmaram que em muitos lugares do mundo os pneus inservíveis têm sido utilizados com sucesso em vários processos industriais, considerando que 
essa possa ser a solução mais adequada tanto ética como econômica e ecológica para os resíduos de pneus.

\subsection{Outras alternativas}

Os pneus ao transformarem-se em inservíveis, ainda poderão ser utilizados, segundo Lund (1993), como:

- recifes artificiais, para a reprodução de animais marinhos, contenção de erosão do solo;

- quebra mares;

- agricultura;

- reciclagem;

- engenharia civil;

- regeneração da borracha;

- geração de energia;

- pavimento asfáltico;

- pirólise;

- equipamentos para playground.

\subsubsection{Recifes Artificiais}

Essa técnica consiste no empilhamento desses inservíveis, que são submersos e ancorados nas áreas costeiras. Submetidos as condições climáticas, esses inservíveis sofrem um rápido processo de incrustação, por meio do crescimento de seres marinhos e algas que os recobrem, resultando num habitat de muitas espécies de peixes. (LUND, 1993) 


\subsubsection{Quebra-Mares}

A construção e implantação de quebra-mares por meio de utilização de pneus inservíveis é uma tecnologia de baixo custo e facilmente adaptável, devido a proteger portos e marinas dos efeitos das mares, bem como por gerar estabilidade para o solo marinho e para a praia.

Se instalados ou construídos de forma ambientalmente adequada, ainda poderão servir como flutuantes na proteção de marinas, baías e portos, além de possibilitarem a estabilização de dunas existentes evitar a erosão de bancos de rios e córregos e proteger os barcos de correntes marítimas. (LUND, 1993).

\subsubsection{Agricultura}

$\mathrm{Na}$ agricultura americana, os pneus utilizados no maquinário para aragem e plantação, por serem maiores e, conseqüentemente, mais pesados, costumam ser reutilizados dentro das próprias áreas agrícolas como bases de suporte, barreiras em estradas e para alimentação de estufas, além de em outras construções existentes nessas áreas. (LUND, 1993).

\subsubsection{Reciclagem}

Segundo Lund (1993), a reciclagem de pneus é um processo muito caro para fabricação em pequena escala, em razão de serem produzidos de material vulcanizado. Porém, compensador se a produção se der em larga escala.

O pneu inservível pode ser reciclado inteiro ou processado. Quando inteiro haverá a inclusão do aro de aço, e quando processado, utilizando processo de corte, fragmentação ou 
moagem, por meio de tecnologias ambiental ou criogênica, somente a banda de borracha será reciclada. (LUND, 1993).

Nesse caso, para a sua recuperação e regeneração, será necessário desvulcanizar a banda de borracha, visando a separá-la dos metais e tecidos que também a compõem. Para esse processamento poderão ser utilizados equipamentos como: separador magnético, moedor, misturador, produtos químicos, picotador, extrusor, laminador, auto-clave, refinador, entre outros.

Esse processo consiste na separação dos materiais, sendo que o inservível é triturado várias vezes até ser reduzido a pó de borracha, o aço removido por meio de eletroímã, e o nylon ficar retido nas peneiras.

A utilização do pó de borracha, substituindo os polímeros, pode ocorrer na confecção de vários novos produtos, como:

- pisos;

- mantas;

- pavimento asfáltico;

- amortecedores;

- tapetes;

- buchas para eixos de caminhões e ônibus;

- saltos e solas de sapatos;

- tiras para indústrias de estofados;

- colas e adesivos;

- cobrir áreas de lazer e áreas de esporte; entre outros.

No processo produtivo, a reciclagem da borracha pode desenvolver um insumo regenerado por menos da metade do custo da borracha natural ou sintética, além de 
economizar energia, de poupar o petróleo e de melhorar as propriedades de materiais confeccionados com borracha.

\subsubsection{Engenharia Civil}

$\mathrm{Na}$ engenharia civil, várias soluções criativas são encontradas como barreiras em acostamento de estradas, quebra-mar, obstáculos para trânsito, recifes artificiais para criadouro de peixes, playgrounds, elementos de construção em parques, contenção nas margens de rios para evitar desmoronamento, controle de erosão, estabilização de manta impermeável em aterros sanitários, entre outros.

$\mathrm{Na}$ última década na Coréia, a maior parte dos pneus inservíveis foi utilizada na área da construção civil para controle de erosão.

Com o intuito de resolver o déficit habitacional, alguns municípios americanos, em Dakota do Sul utilizam placas pré-moldadas confeccionadas com resíduos de borracha, provenientes do processo de recauchutagem de pneus, misturados à argamassa, em substituição à areia. Essas placas são fixadas em pilares de concreto, também pré-moldados.

Trata-se de uma técnica simples e de baixo custo, por meio da qual a municipalidade edifica casas pré-moldadas com cinqüenta metros quadrados, e instalações elétrica e hidráulica, além de isolamento térmico com placas de isopor.

Quanto ao acabamento, fica a critério do morador, que poderá revestir o teto e as paredes com madeira, ou aplicar nestes uma camada de cimento, com posterior aplicação de pintura.

Na Holanda, desde o início do século XX, a empresa Vredestein Rubber Resources, especializada em reciclagem de borracha, vem obtendo avanços nos processos de reciclagem 
de pneus, sendo que a partir de 1980 tem produzido três tipos de borracha a saber: butílica recuperada, natural triturada e natural recuperada.

Esses produtos são utilizados na confecção de câmaras de ar, na composição interna de cabos de telecomunicações, no sistema de sustentação interna de pneus, inseridos no pavimento asfáltico, na confecção de mobiliário para jardins, de equipamentos na área médica e de materiais esportivos.

\subsubsection{Regeneração da Borracha}

A regeneração da borracha envolve a separação da borracha vulcanizada dos demais componentes e a sua digestão com vapor e produtos químicos, cujo produto é refinado em moinhos até a obtenção de uma manta uniforme ou ainda extrusado para obtenção de material granulado.

Destina-se a produtos como tapetes, protetores, solados, saltos de botas de borracha para rodinhos, percintas para fabricação de móveis estofados e outros produtos em menor escala.

No Município de Itupeva, no Estado de São Paulo, existe uma empresa que recicla a borracha de pneus inservíveis por meio de processo de desvulcanização com capacidade de produção de 1700 pneus / hora, equivalendo a um processamento de 90 toneladas / dia.

\subsubsection{Geração de Energia}

$\mathrm{Na}$ geração de energia, os pneus são queimados em fornos protegidos para otimizar a queima, sendo que em outros países sua queima já é uma realidade em fábricas de cimento, e de papel e celulose. 
No caso das fábricas de cimento, a reciclagem se dá por meio da utilização do pneu inservível como combustível, processo que dependerá do tipo de tecnologia e do tamanho do forno

Para tanto, o pneu poderá ser utilizado por inteiro ou na forma de combustível do pneu, o TDF (Tyred Diesel Fuel), considerando que ambos não produzem efeito ambiental adverso ou baixa qualidade de execução e de produto final.

Nos Estados Unidos, assim como na Europa e no Japão, o pneu vem sendo amplamente utilizado como combustível auxiliar em fábricas de cimento, sendo que:

- Estados Unidos: possui sete fábricas que se utilizam de TDF como combustível auxiliar, as quais estão localizadas nos Estados da Califórnia, Arizona, Ohio, e Oregon, e outras oito fábricas que utilizam o mesmo combustível em caráter experimental localizadas nos Estados de Oregon, Washington, Texas, e Carolina do Norte;

- Europa: existem duas fábricas que utilizam pneus inservíveis, sendo uma na Alemanha e outra na Inglaterra:

- Japão: utilizam em quatro fábricas de cimento tanto pneus inservíveis como o TDF. Essas fábricas estão localizadas em Sumitomo, Onada, Chichibu e Osaka.

No que diz respeito às fábricas de papel, também constituem um campo para a reciclagem de pneus inservíveis, em face da possibilidade de utilização do TDF, como combustível suplementar devido ao alto valor calorífico inerente e ao baixo teor de misturas, que o TDF possue.

Contudo, se faz necessária a remoção do metal contido no TDF, o que representa uma desvantagem em relação ao custo do carvão como combustível.

A esse fato somam-se:

- A necessidade de modificações para a permissão de emissões de ar para teste; 
- O custo do transporte face à localização das fábricas;

- E a confiabilidade no fornecimento desse combustível.

Existem oito fábricas de papel e celulose, nos Estados Unidos que utilizam TDF, a saber: duas em Wisconsin; duas na Geórgia; duas no Oregon; uma em Maine; e outra em Washington.

Segundo Lund (1993), o uso do TDF, tanto para fábricas de cimento, quanto de papel e celulose é atrativo. Porém, no caso das fábricas de papel e celulose, a sua utilização onera a produção, em razão de requerer que o ferro seja removido desse combustível.

\subsubsection{Pavimento Asfáltico}

No asfalto modificado com borracha, a reciclagem ocorre por meio da incorporação desses materiais em pedaços ou em pó.

Esse processo possibilita dobrar a vida útil do pavimento, face à borracha conferir ao pavimento maiores propriedades de elasticidade ante mudanças de temperaturas. (D’ALMEIDA; SENA, 2000).

Desde os anos 60, os Estados Unidos vêm adicionando borracha ao pavimento asfáltico. Calcula-se que dessa época até 1993, nesse tipo de tecnologia, já foram utilizados, aproximadamente, 2 milhões de pneus.

Essa tecnologia, segundo Tchobanoglous, Theisen e Eliassen (1993), pode ser executada por meio de dois processos, a saber:

- Processo seco: a borracha do pneu é triturada e utilizada em substituição ao agregado;

- Processo úmido: a borracha do pneu é triturada e incorporada ao asfalto à temperatura de $204^{\circ} \mathrm{C}$, formando uma liga química, denominada asfalto borracha. 
Essa tecnologia, se utilizada pelo processo úmido, tem como vantagem melhorar o desempenho do pavimento asfáltico retardando o aparecimento de trincas, ou selando as existentes. (BERTOLLO, et al., 1999).

\subsubsection{Pirólise}

A Europa vem desenvolvendo o processo de pirólise, também conhecido como destilação destrutiva, desde o final do século IXX.

Esse processo consiste na quebra de cadeias químicas orgânicas por aquecimento, por meio da degradação térmica pela ausência de oxigênio, e é utilizado para transformar pneus pela utilização de seus elementos químicos em outros produtos como: gás, óleo e aço.

A maioria dos processos de pirólise são redutivos, segundo Lund (1993), pois é introduzido gás hidrogênio, visando produzir uma atmosfera reduzida que hidrogeniza os pneus, resultando na produção de um gás de sulfato de hidrogênio, e na conseqüente redução do conteúdo de enxofre de óleo, gás, entre outros.

O óleo é utilizado na indústria química em substituição ao petróleo.

O gás produzido é consumido na própria empresa, quando da produção de óleo e carvão, permanecendo no processo. Ao ser gerado, o gás aquece a caldeira onde se dá a pirólise de outros pneus inservíveis, que gerarão mais gás, que retornará a caldeira para reaquecê-la.

Nessa solução, a energia liberada pela combustão, quer original, ou modificada dos pneus inservíveis é convertida em eletricidade ou vapor.

Essa técnica é indicada para locais onde exista a geração de grandes quantidades destes materiais, uma vez que caldeiras e incineradores que utilizam esses resíduos precisam 
de um estoque contínuo desse material. Por esse motivo, antes desta solução ser adotada, deve ser avaliado o seu custo-benefício.

Nos Estados Unidos, na cidade de Metro, no Oregon, a maioria dos pneus recuperados eram recapeados ou recauchutados, sendo que os resíduos resultantes desse processo eram:

- Processados nas micro-plaquetas apropriadas para o TDF, combustível derivado de pneus;

- Ou processados secundariamente para uso em pavimento;

- Ou em produtos pré-moldados;

- Ou, ainda, em um estoque líquido que, misturado com óleo, era utilizado como combustível industrial, ou marinho, em caldeiras.

No Estado de Maine, nos Estados Unidos, nos anos 80, adotaram a pirólise como tecnologia para obtenção de óleo, no processo de reciclagem dos pneus inservíveis.

Dessa forma, reciclaram cerca de 80 mil pneus / dia, o que corresponde a aproximadamente 400 toneladas desses inservíveis, em que para cada $100 \mathrm{Kg}$. de pneus obteve-se cerca de $52 \mathrm{Kg}$. de óleo.

Apesar do pneu quando queimado inteiro, ou triturado possuir um poder calorífico maior do que o carvão, ele não é utilizado em algumas cidades americanas, em razão do "negro de fumo" gerado em sua combustão, o que obriga a um controle rigoroso do processo, por meio da utilização de filtros que retenham a parte sólida (fuligem) e também a gasosa.

Mesmo com esses resultados, atualmente, as unidades comerciais americanas que operacionalizam a pirólise nos Estados Unidos são uma em Washington, por meio período, e outra na Pensilvânia.

No Brasil, a Associação Nacional de Indústria de Pneus, ANIP, em parceria com a Petrobrás, estão desenvolvendo um projeto de reciclagem de unidades descartadas obtendo óleo combustível por meio da pirólise. (LIMA, 2000). 


\section{NOVOS PROCEDIMENTOS E TECNOLOGIAS DE REDUÇÃO / REUTILIZAÇÃO / RECICLAGEM DE PNEUS}

\subsection{Experiências em Gerenciamento de Pneus Inservíveis}

Os países desenvolvidos vêm implementando uma extensa gama de medidas para a atenuação do impacto ambiental originado pela deposição dos pneus inservíveis no meio ambiente. De acordo com a EPA apud Cimino e Badochi (2002), em alguns países como os Estados Unidos, Japão e Coréia, a reciclagem de pneus aumentou muito, devido ao uso como fonte de energia, pavimentação asfáltica e na transformação em outros produtos.

Nenhum país produz mais pneus inservíveis como os Estados Unidos, onde se calcula que a produção esteja em 285 milhões de pneus ao ano, aproximadamente $4,7 \times 10^{6}$ toneladas, o que fornece um valor per capita de aproximadamente um pneu por habitante.

Dessa quantidade, separando os recauchutados, os não utilizados somam 188 milhões, os quais são enviados para aterros ou depositados ilegalmente.

Por causa dos riscos ambientais foram criadas leis no âmbito estadual e federal, em quarenta e quatro Estados, regulamentando a disposição, armazenamento e processamento dos pneus inservíveis, com o oferecimento de incentivos para novas alternativas e usos.

Além disso, a legislação americana deu aos estados o direito de cobrar multas bem elevadas. Na Califórnia, anteriormente, era cobrada apenas uma multa e o infrator respondia a um processo pelo dano causado; hoje as multas são altíssimas, chegando a U\$ 10.000 violação, além de detenção para o infrator. 
Ainda segundo a EPA apud Cimino e Badochi (2002), a partir de 1999 o Estado de Ohio alterou os procedimentos referentes à disposição de pneus inservíveis, pois desejava conhecer o destino de 9 milhões de pneus inservíveis, dos quais 12 milhões de unidades são geradas anualmente. Para tal realizou-se um cadastramento das empresas que coletavam esses resíduos, resultando no registro de 92 empresas coletoras, com uma frota total de 1.200 veículos.

Com base nesse levantamento obtiveram a informação de que o maior volume desses resíduos era destinado a reutilização do inservível, que triturado era aplicado como cascalho na execução de aterros subterrâneos.

Foi permitida, também, a implantação de 24 galpões para a armazenagem desses inservíveis, sendo que, em 1996, por meio da agência estadual da EPA, localizada nesse estado, foi promovida uma limpeza em oito lixões, de onde foram retirados 2,2 milhões de pneus inservíveis.

Nos anos seguintes, continuaram executando essas limpezas, sendo que em 1999 foram removidos de sete lixões 6 milhões de pneus inservíveis.

Esse programa exclui os pneus utilizados na agricultura e é subsidiado por uma taxa de U\$ 0,50, incluída no valor de cada pneu comercializado.

Nos estados do Arizona, Oklahoma e Colorado forneceram-se incentivos, tais crédito para redução de impostos, por meio da reciclagem, e oferecendo compensações financeiras para os que operam com reciclagem no processamento de energia.

O Colorado, ainda, apresenta regras sobre resíduos de pneus, criando um fundo de desenvolvimento para fornecer o reembolso parcial aos processadores desses resíduos e aos que produzem com matéria-prima de resíduo de pneu reciclado. 
Em Toronto e em Detroit é possível observar os diversos usos criativos dos pneus inservíveis. Foi iniciada uma campanha de conscientização, por meio de uma exposição de trabalhos elaborados com pneus inservíveis, junto com líderes e organizações.

No estado de Kentucky está sendo testado o programa Amnesty de reaproveitamento de pneus inservíveis. Trata-se de um programa de entrega voluntária dos pneus inservíveis pela população e empresários, em galpões destinados a armazenagem, em troca de bônus em função da quantidade encaminhada. Cabe aos recicladores coletar, transportar e processar esses resíduos sem ônus de aquisição.

As mudanças propostas nas legislações ambientais do estado do Arkansas beneficiaram aqueles que armazenavam muito resíduo sólido principalmente os que dispunham de um volume elevado de pneus inservíveis inteiros ou processados.

Segundo a EPA apud Cimino e Badochi (2002), a Comissão de Controle da Poluição pro Ecologia, (PC\&E), do Arkansas está estudando a possibilidade de conceder subsídio financeiro aos bairros, em função do número dos pneus que conseguirem armazenar em ótimas condições de estocagem. O PC\&E considera, também, outras propostas como emendas a sua legislação, em favor do reaproveitamento e reciclagem de pneus. Tais propostas deverão incluir o aumento do volume de pneus que poderão ser armazenados nos seus centros de coleta, com a criação de um sistema de monitoramento do volume desses pneus.

Essas medidas, quanto ao gerenciamento dos resíduos provenientes de pneus inservíveis, constituem-se alternativas viáveis para o nosso país, e sua adoção pode mitigar esse problema já em curto e médio prazos. 


\subsection{Redução na Fonte}

A Michelin Tyred Corporation vem desenvolvendo um método, visando a incorporar na fabricação de novos pneus $10 \%$ de borracha proveniente de pneus inservíveis. Caso esta tecnologia seja aprovada, resultará no reaproveitamento de aproximadamente 30 milhões de pneus inservíveis, representando uma economia de matéria-prima.

\subsection{Reutilização}

Em Minesota um projeto uniu o poder público e a iniciativa privada, por meio da Agência Associados RCM, usando refugos de pneus para reforma e recapeamento de vias e ampliação do sistema habitacional.

Em uma via pavimentada, construída anteriormente, sobre um pântano razoavelmente, profundo, que tinha sofrido recalque de cerca de $1,60 \mathrm{~m}$ em algumas áreas, A RCM reconstruiu três quadras desta via, após o rompimento de trechos ocorridos em 1997, usando micro-plaquetas de pneus inservíveis. Devido a eficiência sobre o solo macio, depois de um ano foi possível observar que a nova pavimentação suportou quatro mudanças de estação, inclusive sobrevivendo ao forte inverno de Minesota.

A RCM continua a monitorar essa via e outras construções para prevenir a ocorrência de rachaduras.

Os construtores crêem ser viável a continuidade da exploração dessa tecnologia, e de modo a aprimorá-la com o passar do tempo, face considerarem as micro-plaquetas de pneus como a melhor solução de engenharia, em termos de assentamentos de solo, destinado a leito de vias. 
Na Pensilvânia são gerados, anualmente, 12 milhões de pneus inservíveis. Em razão desse volume, o Departamento Público de Recreação da Pensilvânia e a Secretaria de Proteção Ambiental criaram ações de incentivo e cinco programas de concessões para projetos de aplicação desses inservíveis em áreas recreacionais públicas, bem como em reciclagem, por meio da criação de mercados para esses produtos, visando à utilização na forma de:

- Combustível,

- pisos de quadras esportivas e

- inserção em pavimento asfáltico.

\subsection{Reciclagem}

De acordo com a EPA apud Cimino e Badochi (2002), as indústrias NRI de Toronto, por meio da reciclagem realizada nas fábricas de Michigan, ajudou a população de Detroit a reutilizar os pneus inservíveis em playgrounds locais.

Além disso, no estado de Michigan, essas indústrias construíram o piso de uma quadra de basquete, utilizando o pneu inservível processado. Essa empresa, por entender que a pesquisa é que introduz o mercado ao crescimento, pesquisou o uso do pó de borracha, proveniente da reciclagem de pneus inservíveis, para utilização como complemento ao solo.

Através dessa pesquisa, foi verificado que o pó de borracha é um dos componentes inorgânicos mais eficientes do solo, superando as propriedades da areia e da lama de serragem. Essa técnica, além de melhorar solos deficientes em zinco, ou com estruturas pobres, ou com pouca permeabilidade, não é onerosa e é bastante durável. 
O Comitê de Conservação da Pensilvânia recebeu U\$ 50000 para reurbanizar o parque estadual, localizado em Pittsburgh, usando material inovador extraído do processamento de pneus inservíveis.

Os passeios do parque receberam pisos executados com pó de borracha processado, provenientes de pneus inservíveis estocados em diversos galpões do estado, bem como foram confeccionados totens de sinalização e outros equipamentos produzidos com o mesmo material. Com base nesse projeto, foi previsto que serão utilizadas cerca de 40 toneladas desses resíduos inservíveis.

No Brasil, segundo informes obtidos do MMA (2002), em cumprimento ao estabelecido pela Resolução CONAMA n, 258/99, a Associação Nacional de Indústrias de Pneus, ANIP, tinha nessa data uma meta de colocar em funcionamento três centrais de coleta de pneus inservíveis no território nacional, sendo uma em João Pessoa/PB, e duas no estado de São Paulo, em Jundiaí e Sorocaba, bem como de, em paralelo, realizar uma Campanha de Conscientização no território nacional, para que a população entregue os seus pneus ao fim de sua vida útil. Visando ao atendimento às quantidades estabelecidas por essa resolução, a ANIP estimou que nesse ano o volume seria de 7,5 milhões de pneus inservíveis, e que para 2003 a quantidade coletada passaria a 15,5 milhões desses inservíveis.

No Brasil, na cidade de Curitiba, foram realizadas experiências na área da construção civil, visando a redução dos custos, durabilidade, e agilidade de sua execução.

Com isso, foi desenvolvido um bloco intertravado, denominado ISOPET, feito de concreto leve, utilizando garrafas plásticas inteiras recicladas com adição de EPS, isopor, e resíduos de pneus.

Esses blocos podem ser posicionados tanto na horizontal quanto na vertical, e por meio de encaixes laterais, do tipo macho e fêmea, é feito o intertravamento entre os blocos, os 
quais necessitam de argamassa somente na primeira fiada, sendo que as demais são encaixadas.

As formas de moldagem de vergas, contra - vergas e cintas de amarração são substituídas por canaletas existentes nos blocos, e para acabamento das paredes se necessita, apenas, de aplicação de argamassa colante de finalização.

A areia está se tornando escassa em Curitiba e esse tipo de tecnologia possibilita a redução de sua extração de recursos naturais, bem como a redução do consumo de energia humana e mecânica, revertendo em custo final mais baixo, assim como em melhor qualidade e produtividade, dentro do princípio de racionalização da construção, além de possuir aspecto termo-acústico.

Esse material foi empregado para a construção da Unidade do Conhecimento, que consiste num protótipo, no qual por meio da utilização de materiais alternativos, objetivou-se reduzir custos, melhorar aspectos termos-acústicos e agilizar a construção, com o aproveitamento de espuma de poliestireno expandido (isopor), resíduos de pneus, e garrafas plásticas, associado a minimização dos problemas ambientais gerados por esses inservíveis, principalmente, no que diz respeito aos pneus.

De acordo com o IPCT (2002), no Laboratório de Tecnologia Ambiental, da Universidade Federal de Minas Gerais, a Professora Rachel Monteiro Lago, baseado no modelo de tecnologia utilizada no Arkansas para desvulcanização, e após dois anos de pesquisas, desenvolveu um processo similar de desvulcanização da borracha, encontrando uma alternativa para esse passivo ambiental a baixo custo e com controle da emissão de poluentes como gás carbônico e dióxido de enxofre. O material resultante dessa tecnologia é um material polimérico, fluído, que pode ser utilizado como graxa, asfalto de maior elasticidade e durabilidade, combustível, plásticos, óleo, pneus novos, e aditivos de outros polímeros. 
No município de Turmalina, no Vale do Jequitinhonha, a Companhia de Saneamento de Minas Gerais, Copasa, está construindo uma barragem no Ribeirão Santo Antonio utilizando Sistema Eco-Estrutural Pneu. Trata-se de tecnologia desenvolvida e patenteada pelo Engenheiro Mecânico Nísio de Souza Armani, por meio da qual os pneus inservíveis são dispostos em camadas ou intercalados em determinados espaçamentos, formando colunas que são preenchidas com outros materiais, como cimento, pedras e entulho grosso.

Nesse sistema destinado a construção civil os pneus inservíveis funcionam como elemento estrutural, na recuperação de grandes áreas degradadas, formando pequenas barreiras, que posteriormente serão revegetadas. Aplica-se na construção de barragens, aterros, muros de arrimo e contenção, silos subterrâneos, alicerces, escadaria, entre outros.

Comparando esse sistema com projetos que utilizam gabião-caixa, constata-se uma vantagem em termos de custo por $\mathrm{m}^{3}$, uma vez que, o processo convencional custa $\mathrm{R} \$ 115,00$, e o sistema proposto sai a $\mathrm{R} \$ 30,00 \mathrm{o} \mathrm{m}^{3}$.

Também experiências de inserção de borracha triturada no pavimento asfáltico, proveniente de recapagem de pneus, têm sido desenvolvidas no território brasileiro, como por exemplo, no Rio Grande do Sul, e a aplicação dessa tecnologia tem sido utilizada em estradas.

Na cidade de Santos, a Prodesan S.A., empresa de economia mista do Município, vem desenvolvendo desde os meados de 1999 esse processo, aplicando esse tipo de tecnologia nas vias públicas, com o objetivo de:

- dar início a estudos que permitam uma destinação adequada aos pneus inservíveis, sem comprometer o meio ambiente e com a possibilidade de redução de custos;

- contribuir para a obtenção de um processo de descarte adequado a um resíduo de difícil solução;

- aproveitar novas oportunidades de mercado em função das necessidades das indústrias darem destino adequado às carcaças desses inservíveis. 
As conclusões a que chegaram foram as seguintes:

- quanto mais regulares forem as partículas, melhor será o resultado;

- a mistura composta de partículas mais finas apresenta maior durabilidade do que se forem utilizadas partículas maiores, que causam total colapso, requerendo a execução de recapeamento;

- a mistura com borracha mantém por mais tempo a temperatura do que na massa referência;

- a trabalhabilidade do produto não é afetada, ficando a massa com uma consistência mais macia e

- os trechos de vias executados com partículas mais finas, após transcorrido mais de um ano de sua aplicação, apresentam as mesmas características de um trecho executado com a massa padrão.

No município de Santa Cruz, no Rio Grande do Sul, o Secretario de Habitação, Engenheiro Leandro Agostinho Kroth, desenvolveu painéis pré-moldados de argamassa e pneu triturado para aplicação em habitação popular de $40 \mathrm{~m}^{2}$, construídas em regime de mutirão.

Esses painéis podem ser rebocados com cimento, para depois receberem aplicação de madeira ou azulejos.

As vantagens dessa tecnologia são:

- aos custos, esse sistema ficou em $\mathrm{R} \$ 3.700,00$, contra $\mathrm{R} \$ 10.500,00$ do sistema convencional;

- quanto ao prazo construída por esse sistema, ser executada em 8 dias.

Nesse município já existem 120 casas construídas por esse sistema.

Percebe-se, assim, que é muito grande o potencial representado pela utilização de pneus inservíveis nas mais diferentes aplicações, e são inúmeras possibilidades desse resíduo 
sofrer uma deposição coerente em relação ao meio ambiente, propiciando ainda emprego e renda para o setor responsável por sua transformação. 


\section{POLÍMEROS}

\subsection{Conceitos Gerais sobre Polímeros.}

O advento dos polímeros se deu posteriormente à revolução industrial, iniciada no século XIX, e trouxe à sociedade moderna enormes benefícios e facilidades.

Constantemente são colocados no mercado mundial novos produtos fabricados a partir de polímeros recém descobertos, com distintas propriedades e características.

De acordo com Chatfield (1962), as principais propriedades dos polímeros dependem da natureza das moléculas constituintes e da força de ligação entre elas.

As propriedades físicas dos polímeros são governadas pela estrutura e tamanho das macromoléculas que determinam as forças intermoleculares.

Os polímeros são substâncias químicas de alto peso molecular obtidos pela reação denominada polimerização, através da qual unidades estruturais de baixo peso molecular, denominadas monômeros, são unidas por ligações covalentes para formar as macromoléculas. (FAZENDA, 1993). As reações de polimerização mais importantes na obtenção de polímeros para uso na construção civil são as reações de policondensação e adição de monômeros insaturados. 


\subsubsection{Polimerização por condensação}

A polimerização por condensação ocorre por etapas e, na maioria das vezes, através da reação entre grupos funcionais diferentes. $\mathrm{Na}$ tabela 7.1 podem ser observados alguns polímeros importantes obtidos por este processo de polimerização. (FAZENDA, 1993).

Tabela 7.1 - Polímeros obtidos por reações de policondensação

\begin{tabular}{ll}
\hline \multicolumn{1}{c}{ Polímero } & \multicolumn{1}{c}{ Reação } \\
\hline Poliésteres & Poliácidos + Poliálcoois \\
Poliamidas & Poliácidos + Poliamidas \\
Uréicas & Uréia + Formol \\
Melamínicas & Melamina + Formol \\
Policarbonatos & Bisfenol A + Fosgeno \\
Poliuretanos & Poliisocianatos + Polióis \\
Epóxi & Bisfenol + Epicloridrina \\
Fenólicas & Fenóis + Formol \\
\hline
\end{tabular}

Fonte: FAZENDA, 1993

\subsubsection{Polimerização por adição}

A polimerização por adição também pode ser chamada polimerização em cadeia, sendo caracterizada pela adição de um monômero a uma espécie química ativada, a qual pode ser um monômero ativado ou uma cadeia polimérica em crescimento. Esse mecanismo de polimerização deve ser acelerado pela aplicação de luz, calor, pressão ou de um catalisador ou iniciador, pois, normalmente, não é uma reação espontânea.

De acordo com Van Vlach (1970), nesse mecanismo de polimerização os pontos de reação do monômero é decorrente da ruptura de duplas ligações e formação de duas ligações 
simples, sem formação de subprodutos. Assim, a regra geral para a polimerização por adição é que o monômero deve possuir pelo menos uma dupla ligação.

\subsubsection{Tipos de Cadeia Poliméricas}

Segundo Mano (1985), os polímeros podem ter suas cadeias sem ramificações, denominados polímeros lineares, ou podem apresentar ramificações, sendo que o grau de complexidade das ramificações pode levar a formação dos chamados polímeros reticulados ou polímeros com ligações cruzadas, também conhecidos como polímeros tridimensionais.

As diferentes conformações dos polímeros acarretam propriedades distintas no produto. Os ramos laterais dificultam a aproximação entre as cadeias poliméricas, diminuindo as interações moleculares, o que ocasiona a "plastificação" do polímero.

A formação de retículos pelas ligações cruzadas entre moléculas dificulta o deslizamento entre cadeias, aumentando a resistência mecânica e tornando o polímero infusível e insolúvel. (MANO, 1985).

Os polímeros lineares ou ramificados, que sofrem fusão por aquecimento e solidificação por resfriamento, são classificados em termoplásticos. Os polímeros que com aquecimento da estrutura tridimensional, reticulada, com ligações cruzadas, tornando-se fixos, insolúveis e infusíveis são chamados termorrígidos. (ALFREY; GURNEE, 1971).

\subsection{Resina Poliuretana (PU)}

A tecnologia das poliuretanas depende principalmente das propriedades e reatividade do radical isocianato $(-\mathrm{N}=\mathrm{C}=\mathrm{O})$. Esse polímero consiste num grupo de átomos extremamente reativos com o hidrogênio ativo de diversas substâncias como as aminas, grupos hidroxilas, 
ácidos carboxílicos, água etc. Basicamente, os poliuretanos consistem de dois componentes, um isocianato e um poliol.

Os poliuretanos são caracterizados pelo tipo de isocianato empregado. Sistemas poliuretanos alifáticos são baseados em isocianatos alifáticos, como por exemplo, o HDI (Hexametileno diisocianato) e IPDI (Diisocianato de isoforona). Sistemas Poliuretanos aromáticos são constituídos por isocianatos aromáticos, por exemplo, o MDI (Diisocianato Difenilmetano) e o TDI (Diisocianato de Tolileno). Os poliuretanos alifáticos são mais caros, mas são os que mais resistem aos efeitos da radiação ultravioleta, além de apresentar maior estabilidade na cor. Os poliuretanos aromáticas apresentam menor custo e resistência à radiação ultravioleta.

Os poliuretanos a base de dois componentes reativos são preparados pela mistura dos componentes isocianato e poliol, antes da aplicação no substrato. Após a mistura os componentes isocianato e poliol, reagem imediatamente, resultando num aumento contínuo da viscosidade até a gelificação, tendo, portanto um limitado tempo de processamento (pot-life). Ao componente poliol são adicionados os demais aditivos, como solvente, catalisadores, pigmento, cargas, aglutinantes, desumidificantes, promotores de fluidez etc, que devem ser inertes e secos. O componente poliol reage à temperatura ambiente com MDI polimérico ou poliisocianatos derivados do HDI, IPDI, TDI etc., como o aduto com trimetilol propano, biuretos, poliisocianuratos etc.

Dependendo das matérias-primas escolhidas e de suas proporções, os polímeros podem variar do macio e flexível ao duro e quebradiço. O aumento do teor de hidroxilas e da funcionalidade do poliol resulta em polimeros mais duros, porém quebradiços, com alto teor de ligações cruzadas e elevada resistência química. Por outro lado, o uso de polióis com baixo teor de hidroxilas e funcionalidade igual ou pouco superior a dois resulta em polimeros mais 
macios e flexíveis. O tipo e teor de extensor de cadeia, que junto com o isocianato dão origem aos segmentos rígidos, têm grande influência nas propriedades finais do polímero.

Os PU's podem ser obtidos por processos em uma etapa, no qual todas as matérias primas são misturadas simultaneamente ou processos em duas etapas, em que se faz a reação prévia do poliol, normalmente com excesso de isocianato, formando um prepolímero com terminação NCO. O teor de NCO livre do prepolímero é dado pela relação isocianato/poliol $(\mathrm{NCO} / \mathrm{OH})$ utilizada. Quando a relação $\mathrm{NCO} / \mathrm{OH}$ é muito superior ao dobro da estequiométrica, o produto resultante, denominado semi- ou quasi-prepolímero, possui grande excesso de isocianato livre não reagido, que aumenta a sua toxidade e sofre restrições em muitas aplicações, principalmente com os isocianatos mais voláteis. Na segunda etapa do processo ocorre a formação dos poliuretanos e poliuretanos/uréias de alto peso molecular pela reação dos prepolímeros terminados em NCO com dióis, diaminas, ou umidade do ar; e com os agentes de cura mais o restante do poliol, no caso dos quasi-prepolímeros.

\subsection{Resina Poliuretana Derivada do Óleo de Mamona}

Araújo (1992) menciona que a resina poliuretana constitui um material preparado por espécies quimicamente ativas contendo o grupo-NCO com polióis funcionalmente ativos, resultando em polímeros com diferentes características e com excelentes propriedades, apresentando aplicações amplas, sendo materiais favoráveis sob vários pontos de vista, tais como :

- propriedades reológicas (viscosidade, fluidez, tixotropia, comportamento em variação de temperatura );

- tensões superficiais, umedecimento (poder umectante) e penetração capilar;

- tempo máximo e mínimo de processamento; 
- endurecimento e cura; e, principalmente,

- economia

Assim como para outros polímeros, as propriedades dos vários tipos de poliuretanas dependem de sua massa molecular, grau de entrecruzamento, forças intermoleculares, rigidez dos segmentos da cadeia e cristalinidade. Uma propriedade importante das poliuretanas é a versatilidade quanto à variação de suas estruturas. (ARAÚJO, 1992).

Em 1983, o Laboratório de Química Analítica e Tecnologia de Polímeros (LQATP) iniciou no Instituto de Química (IQ-USP) a pesquisa e desenvolvimento de polióis para poliuretanas, cujo objetivo principal foi desenvolver materiais para aplicações em telecomunicações, o que permitiu adquirir conhecimento na área de síntese de intermediários para resinas poliuretanas.

A resina poliuretana derivada do óleo de mamona possui a vantagem de ser um material obtido a partir de recurso natural e renovável. Já a poliuretana derivada da indústria petroquímica possui a matéria prima para sua produção nos compostos derivados do petróleo, que são recursos esgotáveis, além de serem prejudiciais à saúde.

As poliuretanas são sempre mencionadas como exemplos de materiais que combinam alta resistência mecânica com elevado grau de estiramento antes da ruptura $(\%$ de alongamento). Esta combinação de propriedades básicas das poliuretanas leva à combinação de enormes resistências ao impacto e abrasão, além de excelente resistência à maioria dos líquidos orgânicos na forma de óleos e fluídos. (ARAÚJO, 1992, p.10).

A versatilidade de propriedades apresentada pelas poliuretanas é explicada devido à estrutura química simplificada de uma resina típica representada conceitualmente na figura 7.1: 


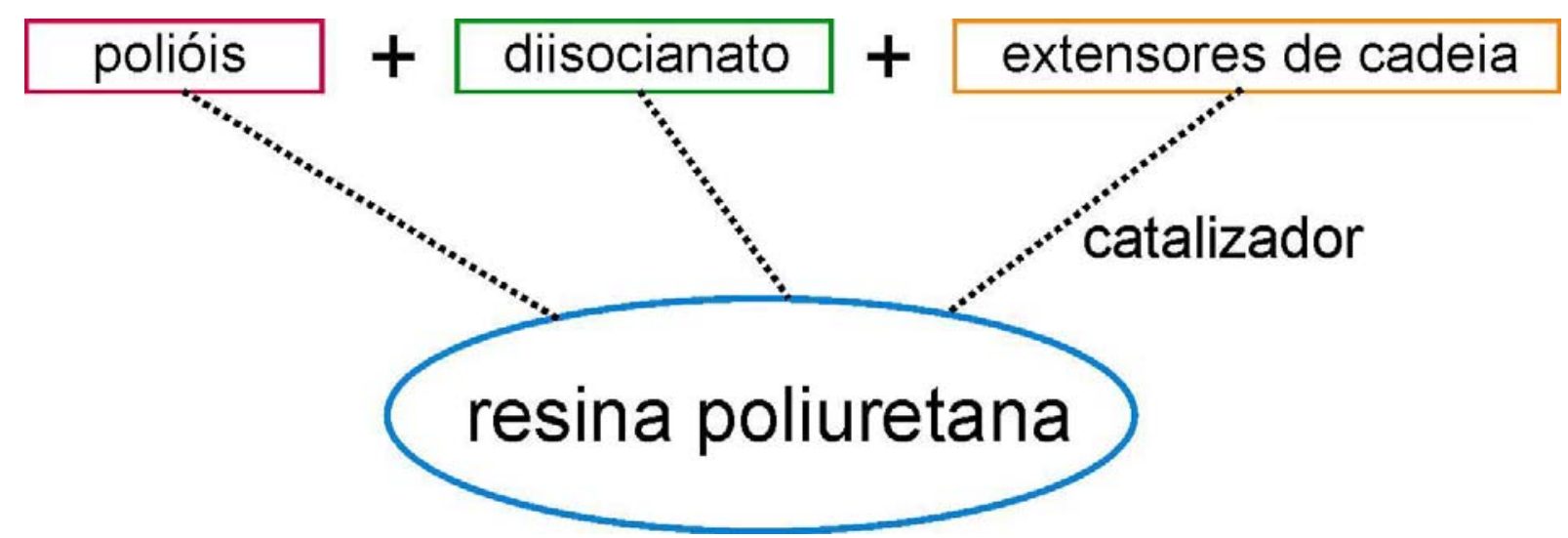

Figura 7.1 - Esquema de um processo conhecido para preparação de poliuretanas Fonte: ARAÚJO, 1992

Essa figura mostra o bloqueio linear que ocorre no processo de síntese do polímero, destacando-se na estrutura básica dos três tipos de intermediários de síntese: o poliól, diisocianato e extensores de cadeia. Desta forma, as propriedades do polímero, tais como a flexibilidade, rigidez, interpenetração de segmento, força intercadeia e entrecruzamento molecular são explicadas a partir do balanceamento desses intermediários para poliuretanas (ARAÚJO, 1992).

Ainda acordo com Araújo (1992), existem duas rotas básicas para a síntese das poliuretanas, a rota de processo de uma única etapa, apresentada na figura 7.1, e a rota do prepolímero, representada na figura 7.2: 


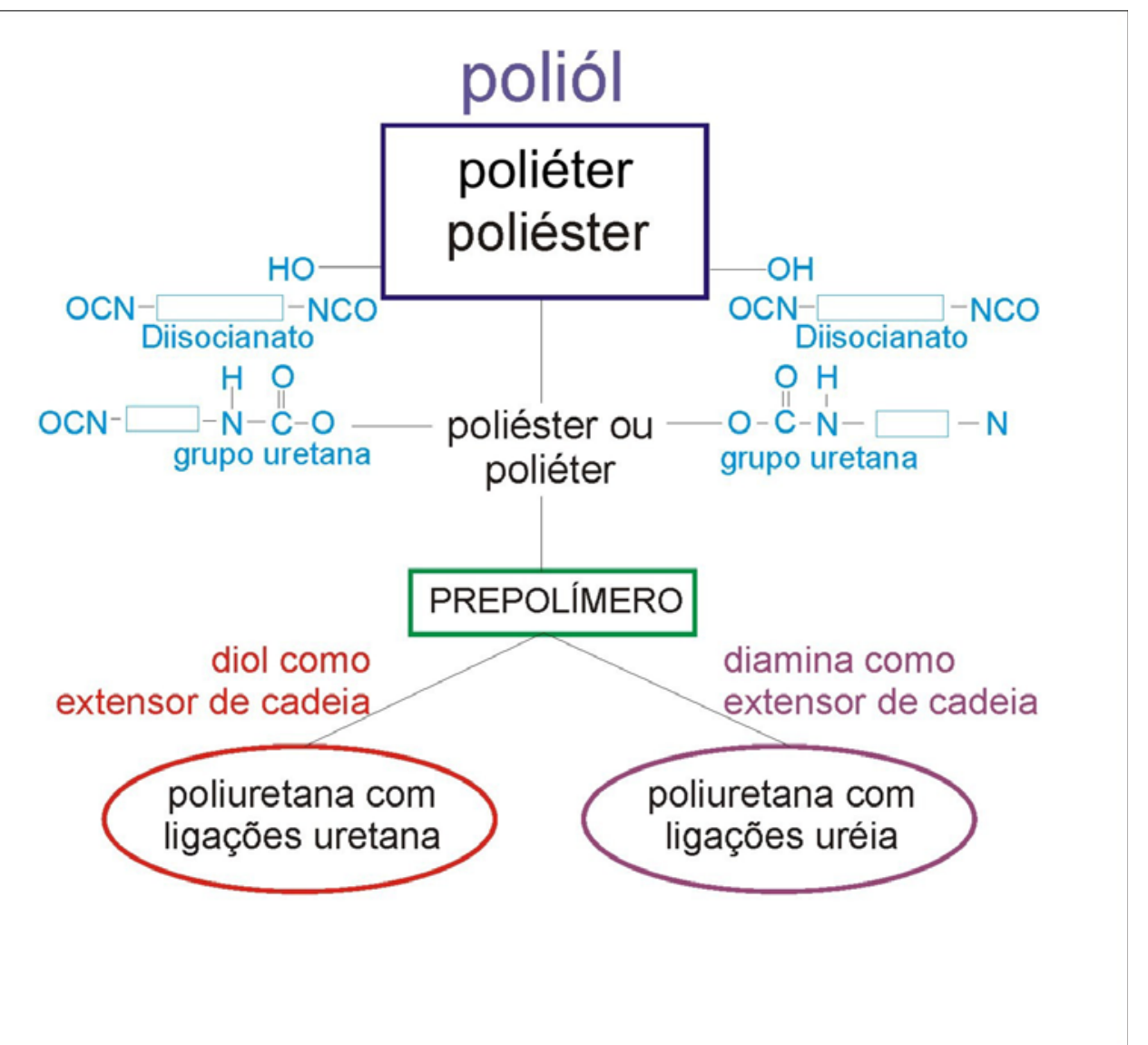

Figura 7.2 - Rota de síntese para a formação do pré-polímero poliuretana elastomérica Fonte: ARAÚJO, 1992

A reação de polimerização ocorre pela mistura a frio do poliól (a base de mamona) com o prepolímero (isocianato). Essa reação é que conduz a policondensação Uretana. Podese não só aumentar ou diminuir a percentagem de poliól, que irá definir maior ou menor dureza do poliól, além da velocidade da reação. Se necessário, emprega-se um catalisador adequado para aumentar a velocidade de polimerização. Normalmente, a polimerização completa das resinas poliuretanas verifica-se, aproximadamente, num intervalo médio de 90 à 120 minutos para cada tipo de resina poliuretana, com catalisador, e sem catalisador e com a reação ocorrendo a quente. 
Através de procedimentos experimentais, Araújo (1992) verificou a estabilidade térmica das poliuretanas entre 215 e $340^{\circ} \mathrm{C}$. Pelos termogramas dos ensaios, pode-se notar que até $220^{\circ} \mathrm{C}$ ocorre uma pequena perda de massa.

Também foi verificado por Araújo (1992) que as propriedades mecânicas das resinas poliuretana de origem vegetal estudada variam em função das proporções entre o prépolímero, responsável pelos sítios rígidos, e o poliol. Assim, as resinas com maior proporção de pré-polímero apresentam maior rigidez, maiores tensões de ruptura e menor flexibilidade.

Os sistemas que possuem diisocianatos aromáticos disfuncionais sofrem descoloração sob a ação da luz devido a sua aromaticidade.

\section{4 Óleo de Mamona}

A mamona (Ricinus communis L.) pertence à família Euphorbiaceae, que engloba vasto número de tipos de plantas nativas da região tropical. É uma planta do tipo arbusto, com diversas colorações de caule, folhas e racemos (cachos), podendo ou não possuir cera no caule e pecíolo. Os frutos, em geral, possuem pontas e, em alguns casos, são inermes. As sementes apresentam-se com diferentes tamanhos, formatos e grande variedade de coloração.

O óleo de mamona ou de rícino, extraído pela prensagem das sementes, contém $90 \%$ de ácido graxo ricinoléico, que confere ao óleo características singulares, possibilitando ampla gama de utilização industrial, tornando a cultura da mamoneira importante potencial econômico e estratégico para o País.

A torta de mamona é muito utilizada como adubo orgânico possuindo, também, efeito nematicida, mas não se presta à alimentação de animais. 
O óleo de mamona é uma fonte quase pura do ácido graxo ricinoléico, cujas propriedades e estrutura da cadeia carbônica conferem propriedades singulares ao óleo de mamona.

A cadeia carbônica do ácido graxo ricinoléico proporciona sítios em que são realizadas reações químicas, com obtenção de gama variada de derivados pela modificação da estrutura da cadeia carbônica. São mencionadas cerca de quatrocentas aplicações do óleo de mamona, a maioria na formulação de produtos biodegradáveis, geralmente invisíveis aos leigos.

A aplicação industrial de derivados de óleo de mamona se verifica em diferentes setores produtivos, e se constitui em um material estratégico, até imprescindível para alguns tipos de utilizações, tais como na indústria aeronáutica e automobilística.

O óleo de mamona é definido por Araújo (1992) como um triglicéride natural de amplas aplicações industriais, não comestível, e sua estrutura pode ser observada na Figura 7.3. O óleo de mamona age quimicamente como um triol na síntese das poliuretanas, ou seja, apresenta três agrupamentos - $\mathrm{OH}$ secundários (não terminais), sendo, portanto, pouco reativo em relação aos grupos - NCO.

O óleo de mamona tem como componente majoritário o ácido 12-hidroxioleico (ácido ricinoleico) esterificado com glicerina (ANDRÉ, 1921 apud ARAÚJO, 1992). Possui um sítio de instauração (HILDITH, 1947 apud ARAÚJO, 1992), ou dupla ligação olefínica, entre os carbonos 9 e 10 do ácido ricinoleico, e uma hidroxilano carbono 12. São os três sítios de ataque químico que conferem ao óleo de mamona a excepcional versatilidade como matéria prima oleoquímica. Esta propriedade torna o óleo de mamona um produto potencial do ponto de vista tecnológico. (ARAÚJO, 1992). 


\section{ESTRUTURA QUÍMICA DO ÁCIDO RICINOLÉICO (ÓLEO DE MAMONA)}

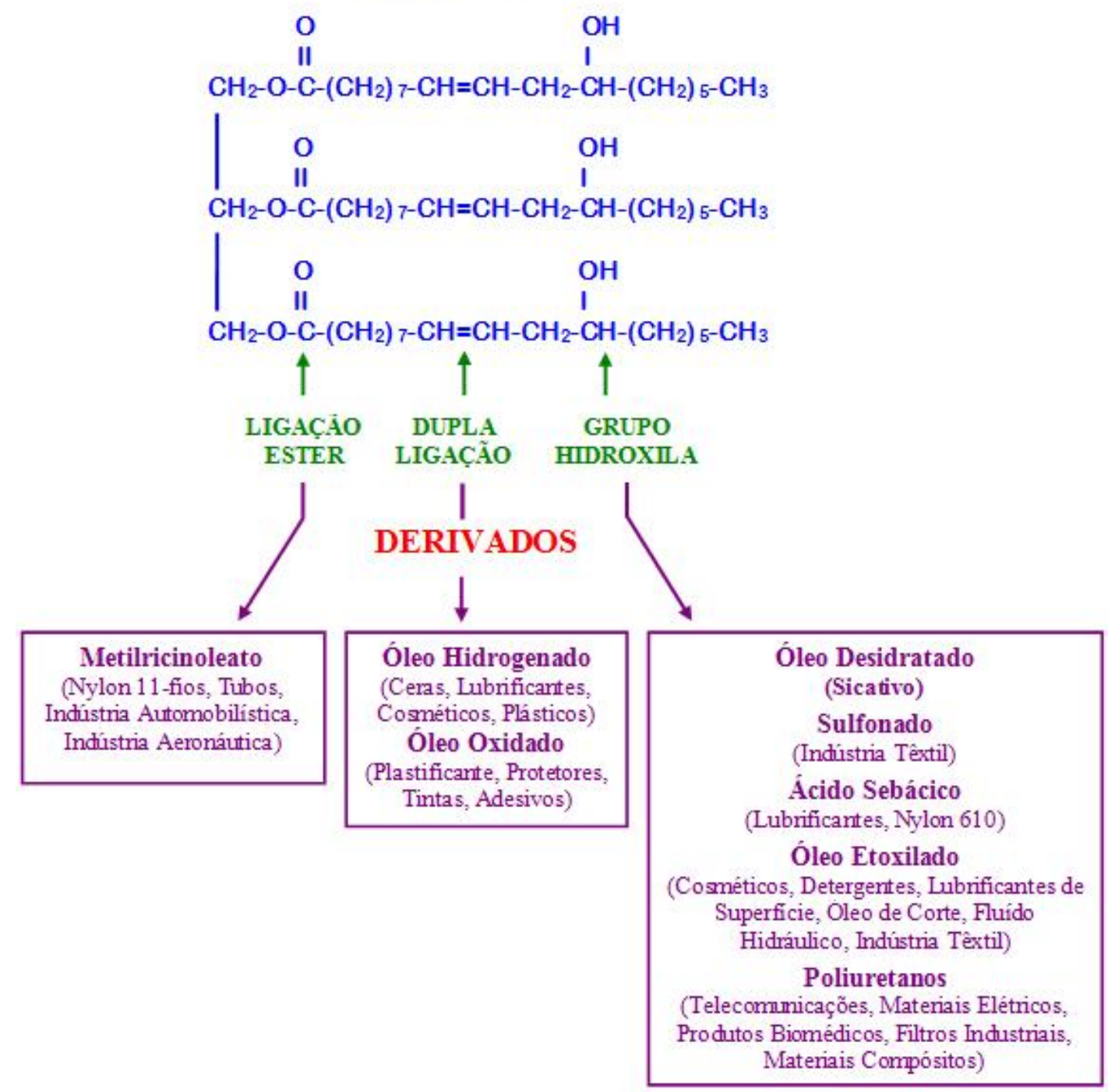

Figura 7.3 - Estrutura do óleo de mamona mostrando seus principais pontos de modificações estruturais 
Na Figura 7.4 temos um fluxograma do processo de extração do óleo de mamona e seus vários derivados.

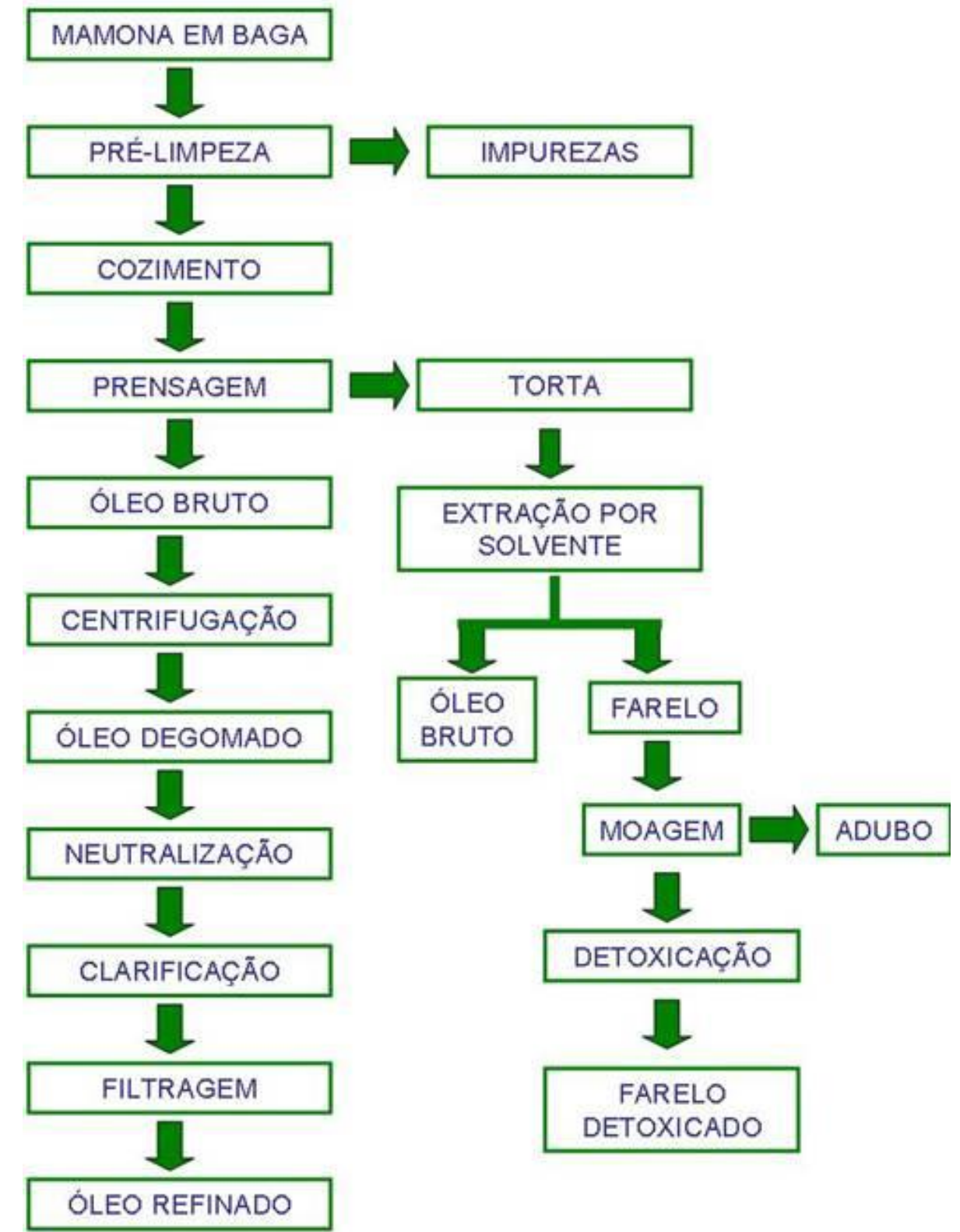

Figura 7.4 - Fluxograma do processo de extração do óleo de mamona Fonte: IAC - http:// www.iac.sp.gov.br

A extração do óleo de mamona, conforme se pode verificar das figuras 7.4 e 7.5 , não apresenta dificuldades, sendo que até um médio ou mesmo pequeno produtor rural pode reunir as condições para exploração deste importante insumo agroindustrial, gerando emprego e renda para o setor. 


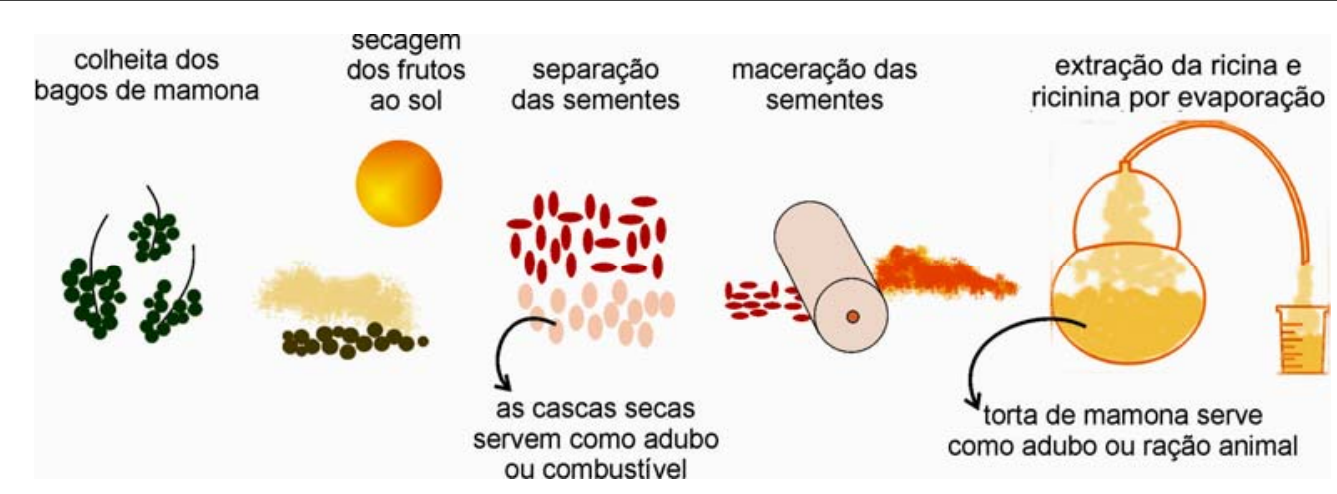

Figura 7.5 - Processo representativo de extração do óleo de mamona
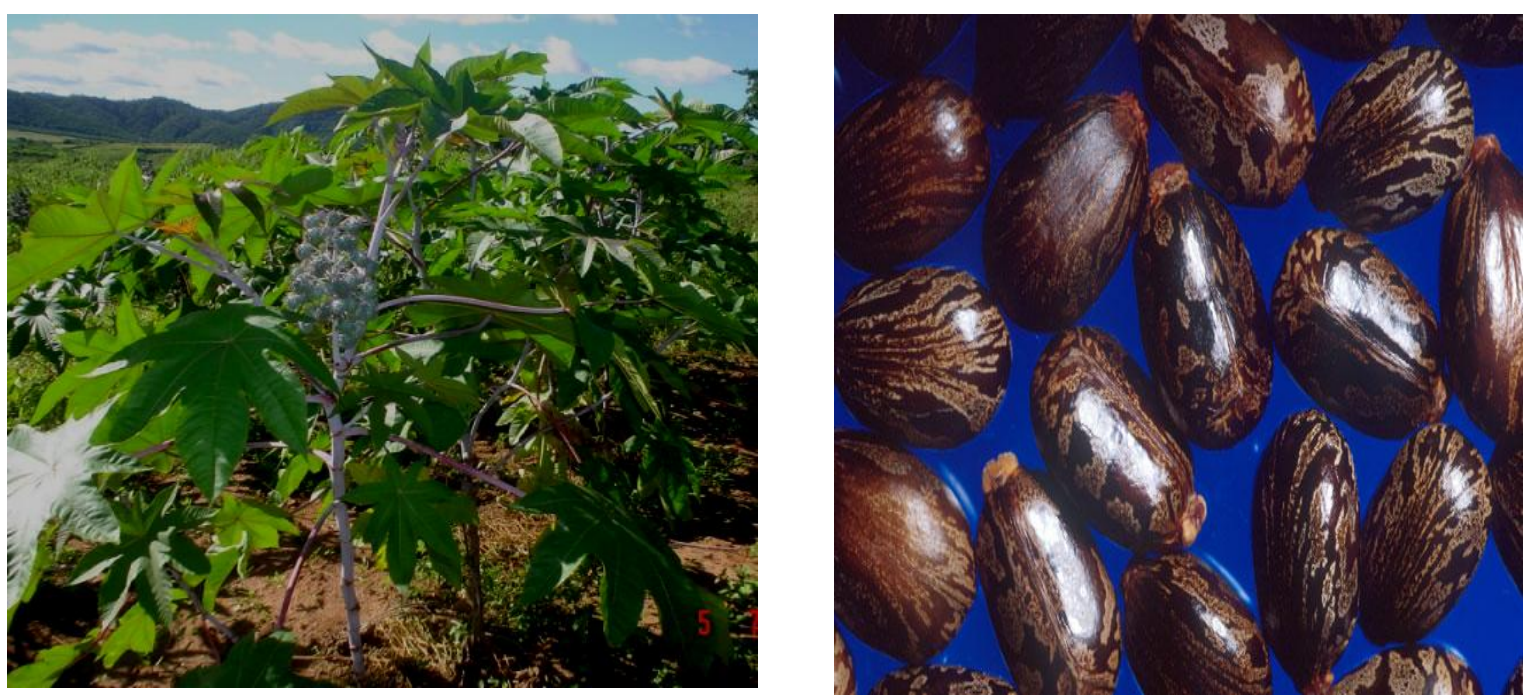

Figura 7.6 - Folhas, fruto e semente da mamona

\subsection{Utilização de resina poliuretana de óleo de mamona em Compósitos}

A utilização da resina poliuretana originária do óleo de mamona vem sendo muito utilizada em várias áreas da construção civil. Godoy (2007) desenvolveu um compósito a base de madeira de reflorestamento e resina PU para a fabricação de isoladores elétricos híbridos, e os estudos com cruzetas de madeira mostraram que este material apresenta excelente desempenho em ensaios de nível básico de isolamento.

Wiedman (2002), desenvolveu um processo de produção para a fabricação de peças de mobiliário e telhas de cobertura a partir de compósito com fibra extraída do fruto do coqueiro (Cocos nucifera) combinada a resina poliuretana. 
Schultz (2005), produziu um painel de configuração sanduíche com o núcleo em compósito polimérico, constituído pela aglomeração de resíduos diversos numa matriz de resina poliuretana vegetal.

Milanese (2008), desenvolveu compósito a base de fibras naturais e de vidro aglomeradas com poliuretana, visando o reforço nas ligações de estruturas de madeira laminada.

Mendes (2002), desenvolveu compósito a base de grafite e resina poliuretana, para aplicações eletroanalíticas. A resina utilizada foi bi-componente e pode ser facilmente misturada ao grafite por simples maceração. A dureza do compósito resultante, permitiu sua usinabilidade e construção do eletrodo com diferentes geometrias.

Altafim et al. (2000), promoveram a execução de isoladores poliméricos com resina poliuretana derivada do óleo de mamona e cargas minerais.

Campos e Lahr (2004), desenvolveram chapas de madeira MDF, com fibras de pinus aglomeradas com resina poliuretana de óleo de mamona e apresentaram resultados muito interessantes, pois foram obtidos resultados físicos e mecânicos semelhantes a painéis de madeira para uso estrutural na construção civil.

Mothé e Araújo (2004), estudaram o comportamento térmico e o mecanismo de decomposição térmica de compósitos de poliuretano nas proporções de: 5, 10 e 20\%(p/p) de fibra de curauá. A incorporação de fibra nos compósitos de PU com curauá provocou um aumento no módulo de Young e uma diminuição na deformação na ruptura.

Silva (2003) procedeu a aglomeração de fibras vegetais de sisal e de coco com resina poliuretana derivada do óleo de mamona.

Lapo e Beraldo (2008), um compósito com bambu laminado e colado com resina PU a base de óleo de mamona, a qual revelou excelentes qualidades como adesivo. 


\section{MATERIAIS E MÉTODO}

Neste capítulo estão descritos os procedimentos experimentais adotados na caracterização dos materiais e os ensaios efetuados, desde a etapa preliminar, onde se determinou as propriedades do compósito, a partir de misturas fazendo variar a relação entre resíduo de borracha $\mathrm{x}$ resina $\mathrm{PU}$, até os resultados finais, obtidos a partir do compósito considerado como o mais adequado para a consecução de produtos potencialmente utilizáveis na construção civil.

Estão constados aqui os ensaios que foram considerados mais adequados para a caracterização do compósito em estudo, e ao longo do trabalho, a partir da experiência acumulada através das análises efetuadas, pode-se ir desenvolvendo dispositivos e métodos de ensaios sem os quais seria impossível chegar-se a resultados representativos das propriedades do compósito.

Foi feita uma extensa varredura das características mais importantes que um novo material deva atender na sua introdução ao mercado, na forma de diferentes produtos. Para isso, baseou-se em ensaios rotineiros aplicáveis a materiais borrachosos e elastoméricos, procurando-se abranger a investigação do maior número possível de propriedades. 


\subsection{Borracha}

O estudo prévio da composição granulométrica mais adequada para a constituição do compósito foi procedido como forma de obter a máxima compacidade das partículas de borracha, segundo suas diferentes dimensões, determinadas pelo processamento de moagem dos pneus inservíveis na usina recicladora ${ }^{3}$.

Neste processamento industrial, as partículas são separadas granulometricamente segundo as dimensões de peneiras que diferem da serie normal adotada para agregados utilizados em concreto. Estas partículas se apresentam segundo dimensões caracterizadas como P5, P10, P20 e P30, que equivalem, respectivamente, aos "meshes" das aberturas das malhas de peneiras adotados comercialmente. As Figuras 8.1 a 8.5 apresentam as particularidades de uma usina recicladora de pneus.

Em função das facilidades propiciadas pelos equipamentos disponíveis no Laboratório de Construção Civil da EESC - USP e nos do laboratório do INTEP $^{4}$, foi procedido o peneiramento das frações granulométricas recebidas da usina recicladora, de maneira a melhor classificar as amostras, segundo a série normal de peneiras constante da NBR 7217.

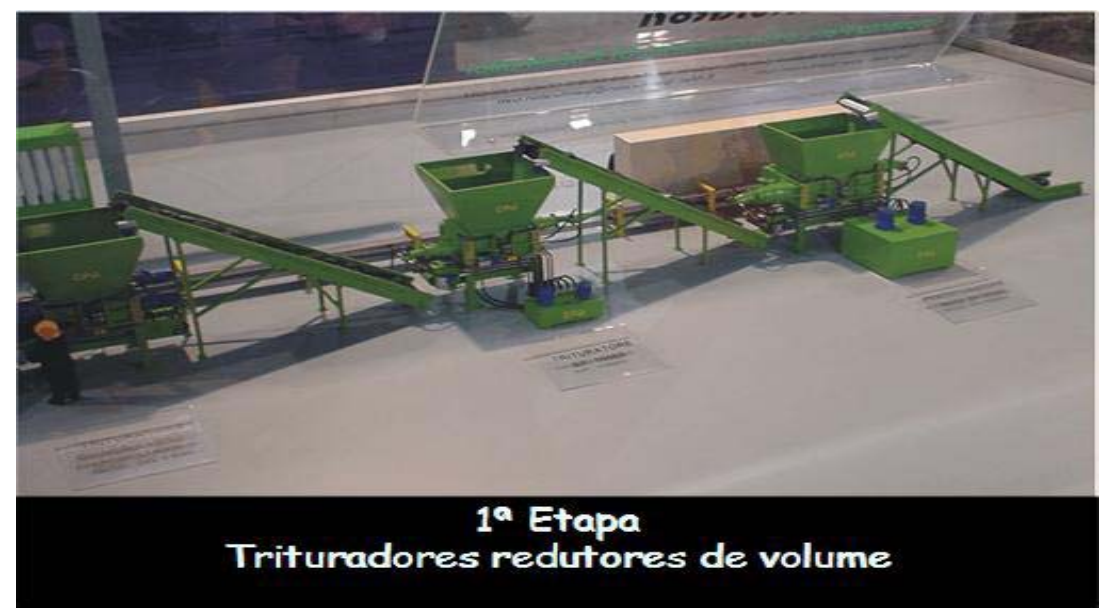

Figura 8.1 - Maquete de usina de reciclagem obtida do catálogo do fabricante (trituradores de mandíbulas) ${ }^{5}$.

\footnotetext{
${ }_{4}^{3}$ Usina de Processamento pertencente ao Grupo BALBO, localizada em Cravinhos - SP

${ }^{4}$ INTEP- Instituto Tecnológico de Estudos e Pesquisas de São José do Rio Preto - SP, ligado às Faculdades Integradas Dom Pedro II, de São José do Rio Preto - SP.

5 Em razão das grandes dimensões do equipamento industrial, apresentaram-se fotos da maquete da linha de produção.
} 


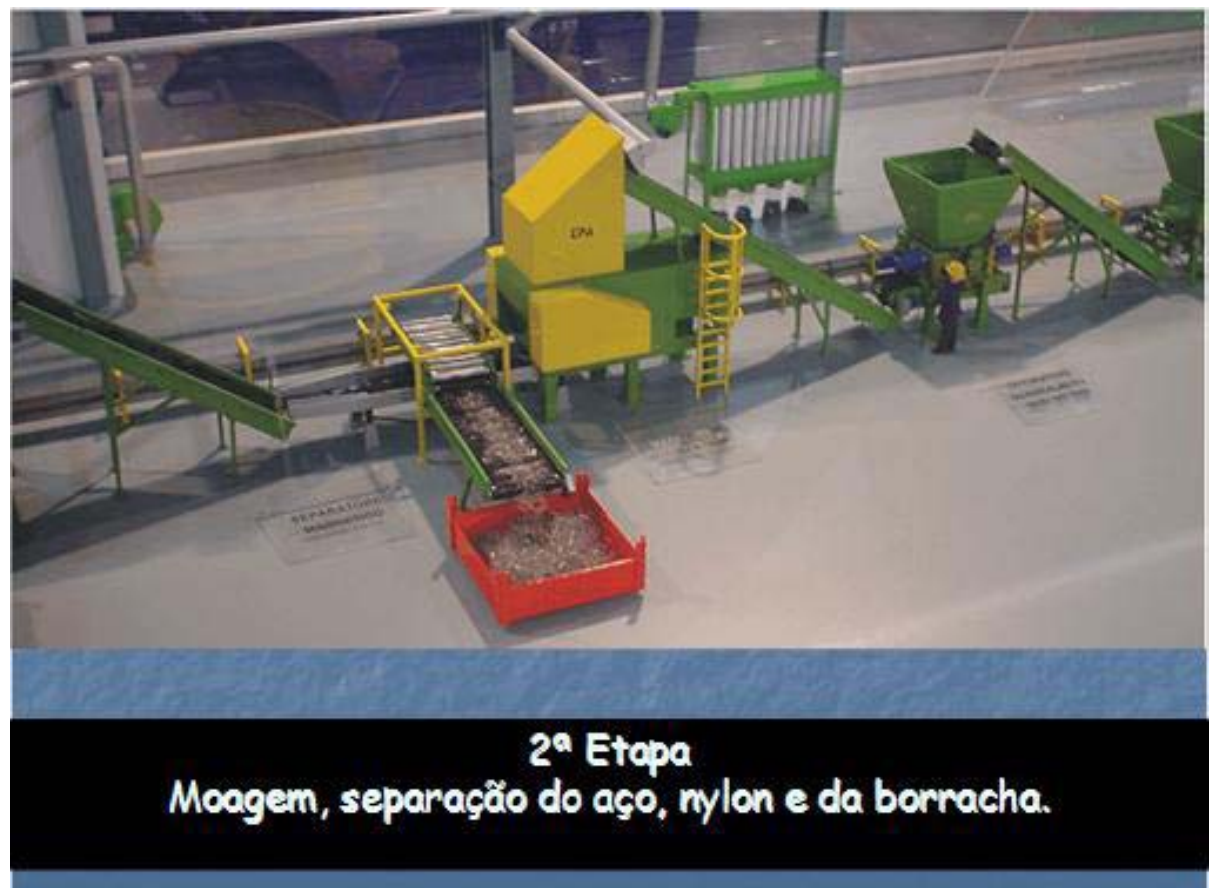

Figura 8.2 - Maquete de usina de reciclagem obtida do catálogo do fabricante (etapa de separação dos constituintes do pneu).

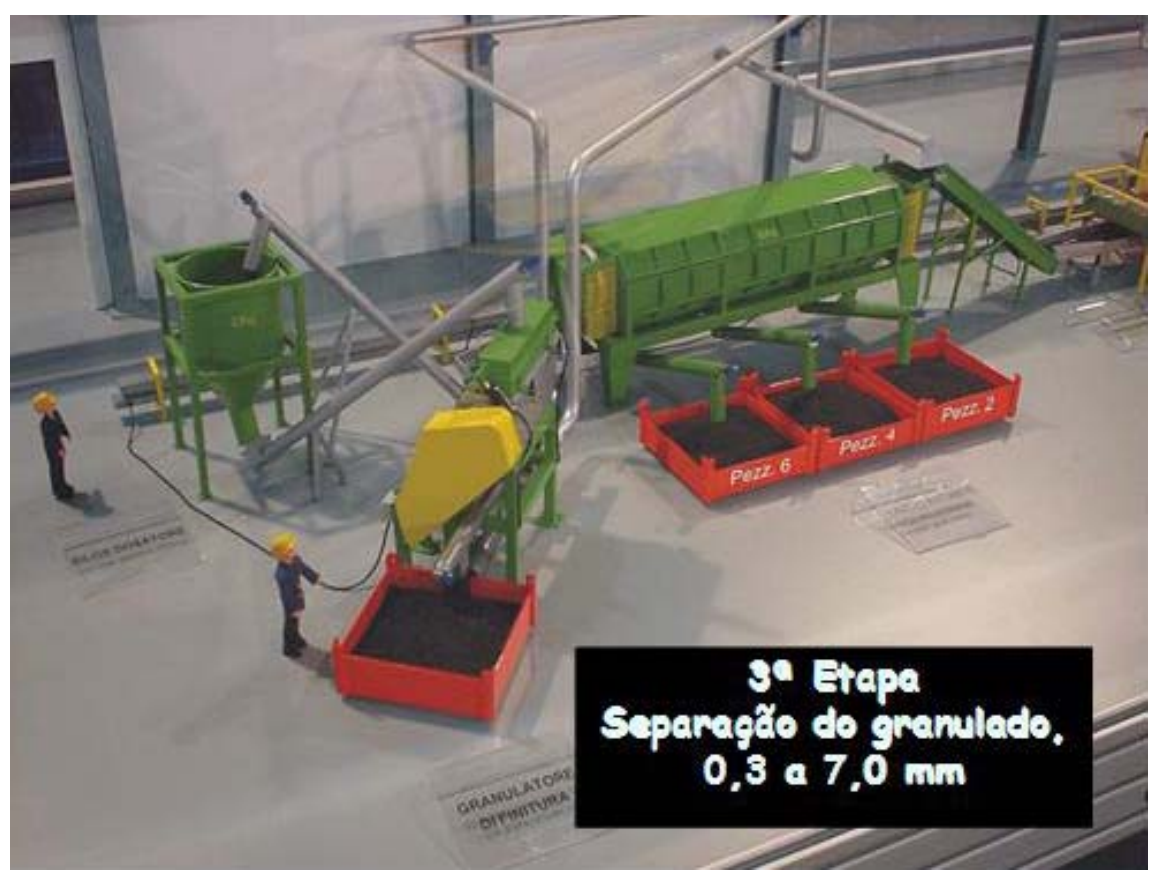

Figura 8.3 - Maquete de usina de reciclagem obtida do catálogo do fabricante (peneiradores) 


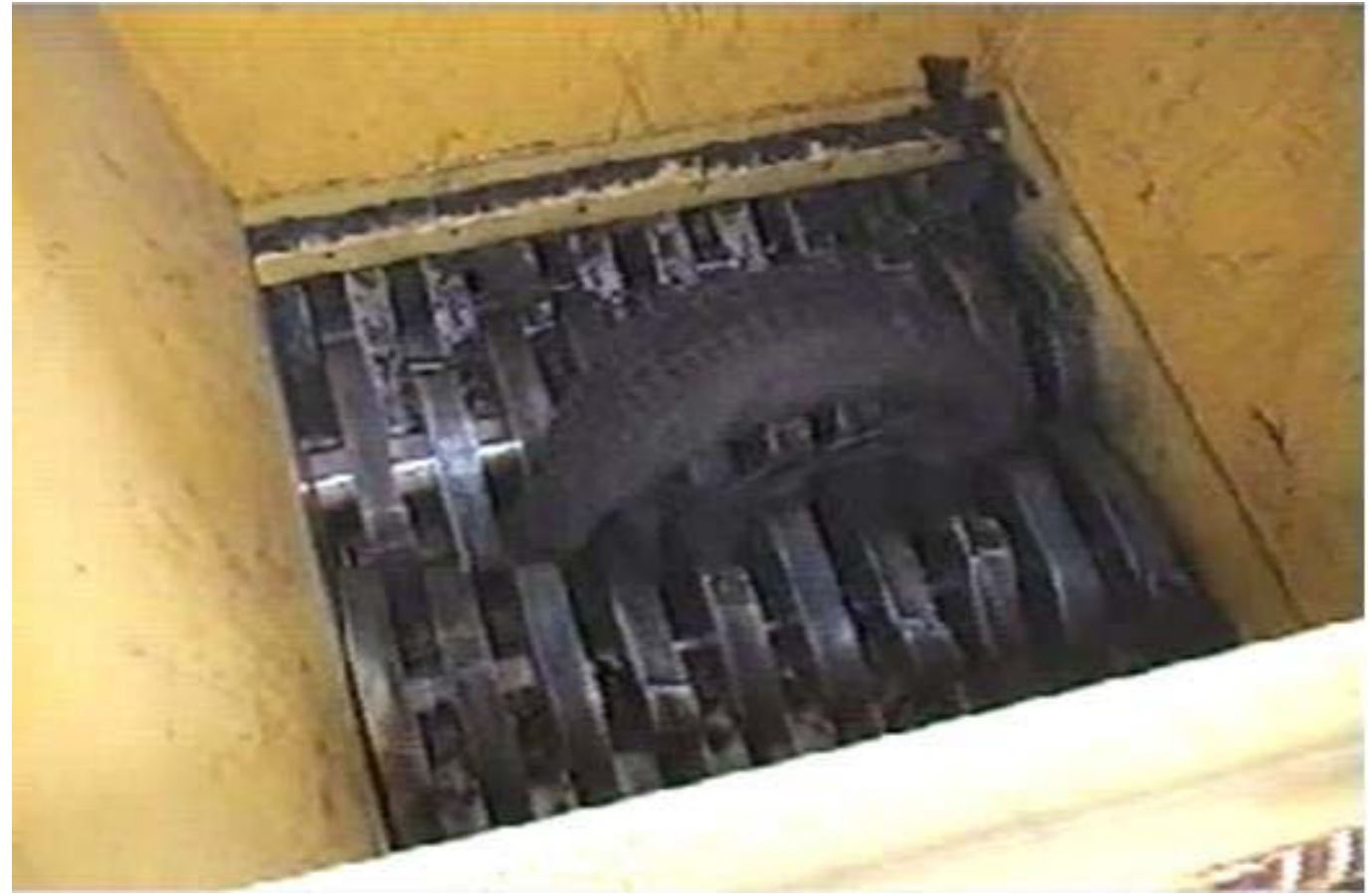

Figura 8.4 - Moenda da usina de reciclagem EcoBalbo (trituradores de mandíbulas) foto do autor

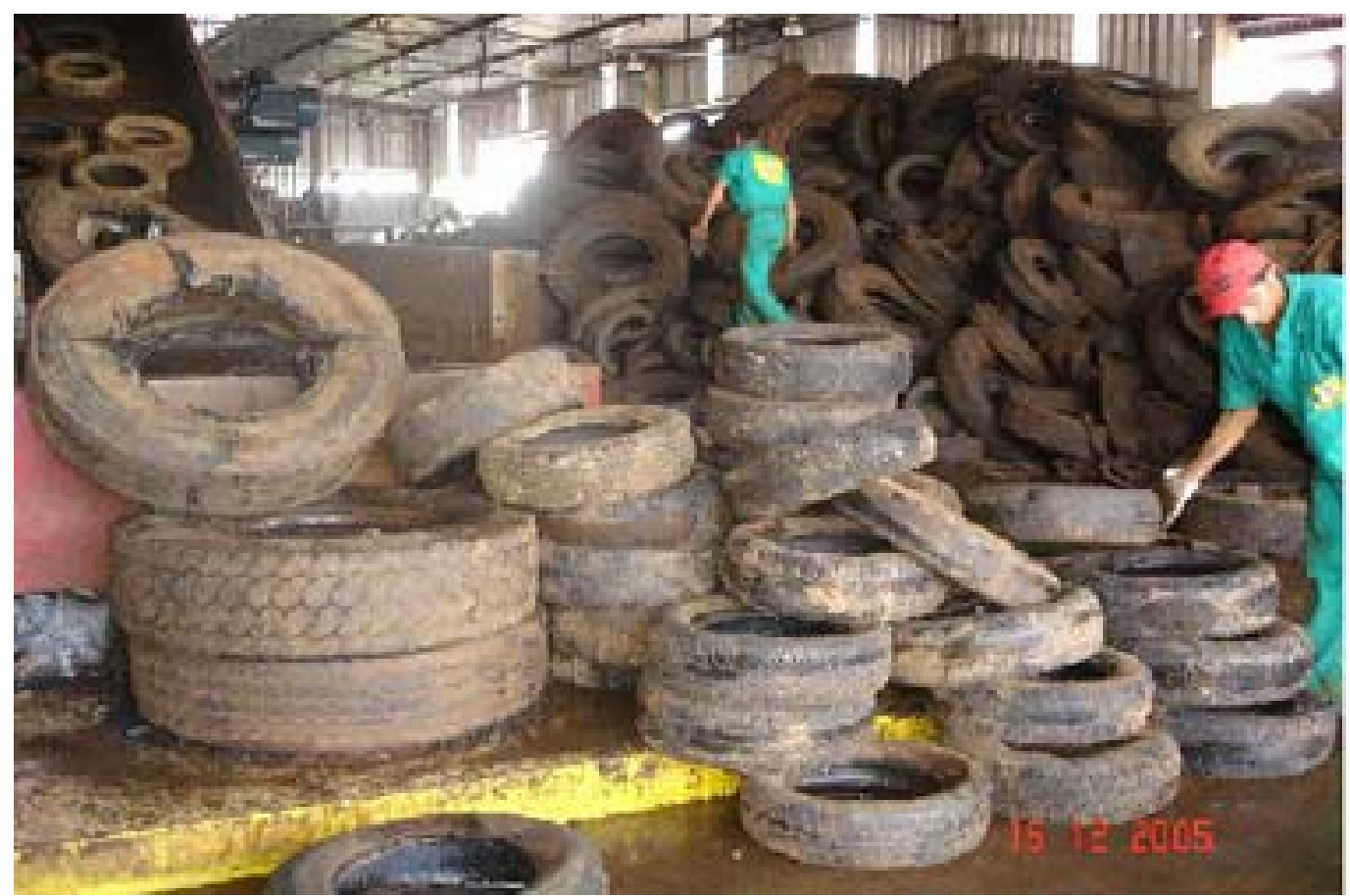

Figura 8.5 - Entrada dos pneus na moenda, depois da retirada dos talões (EcoBalbo) foto do autor 
Na Figura 8.6 são apresentadas as partículas de pneus triturados nas diferentes granulometrias segundo o processo industrial de moagem dos pneus inservíveis. É comum se observar a presença de pequenos pedaços de fibras de nylon e de fibras de aço, que não foram separadas após o processo de moagem. As fibras de nylon são retiradas mediante aplicação de ar em fluxo ascendente, e as fibras de aço separadas por meio de um eletroímã disposto sobre a correia transportadora.
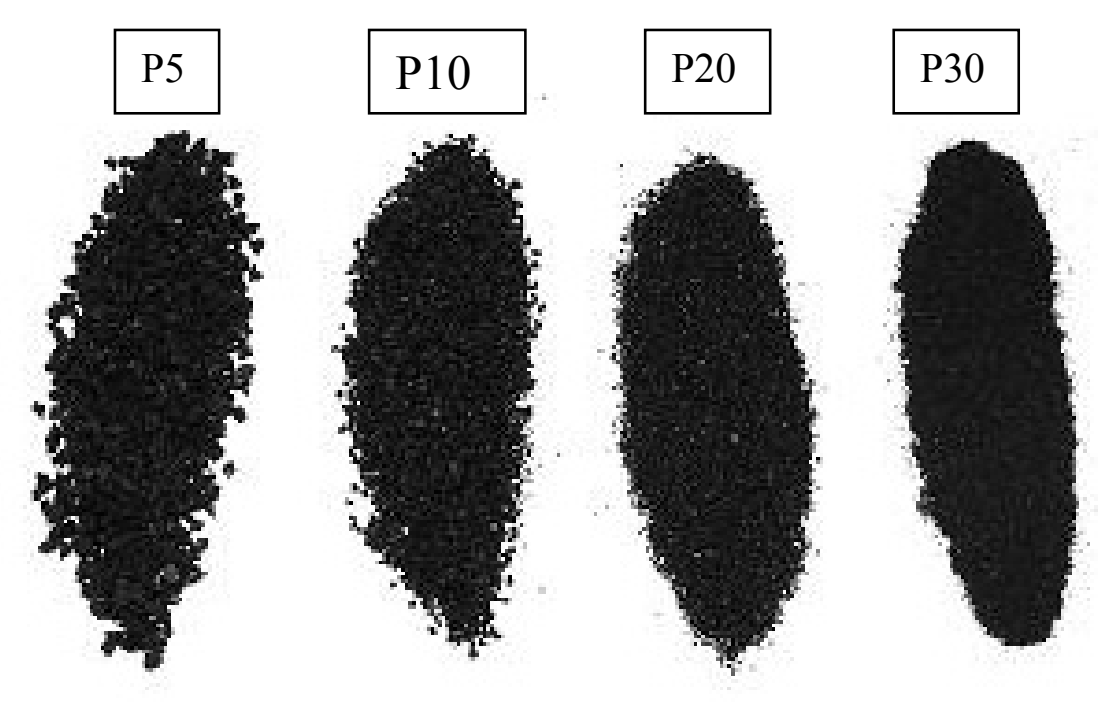

Figura 8.6 - Partículas moídas de borracha de pneu, constituindo as quatro amostras obtidas da usina de reciclagem

\subsection{Resina Poliuretana}

Foi adotada a resina poliuretana derivada do óleo de mamona para a constituição do compósito contendo partículas de borracha de pneus inservíveis por ser este um material obtido a partir de recurso natural e renovável e apresentar propriedades adequadas para a formação do compósito em estudo.

A Figura 8.7 apresenta folhas, frutos e sementes da mamona e os dois constituintes da resina poliuretana. 

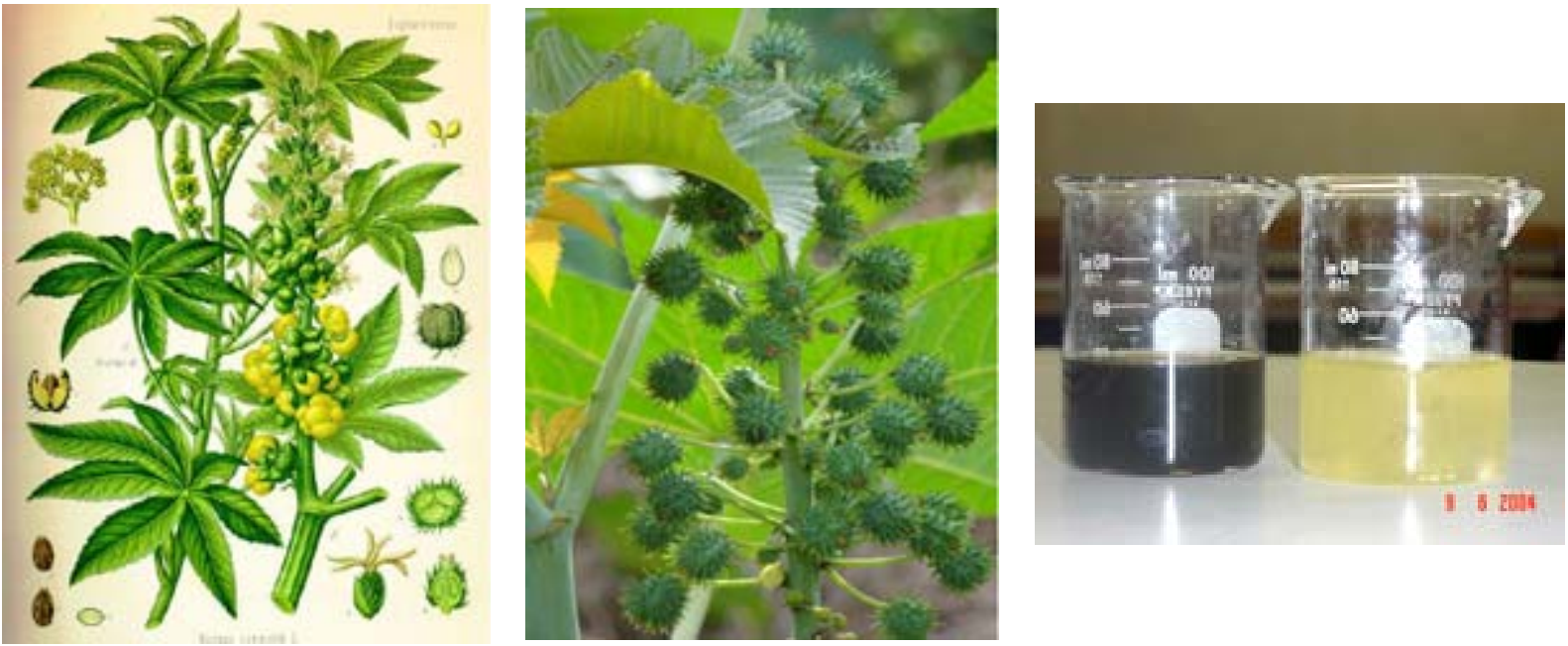

Figura 8.7 - Planta Mamona (Ricinus communis), Pré-polímero e Poliol que compõem a resina poliuretana de origem vegetal

A Figura 8.8 representa a mistura dos dois constituintes da resina, que podem ser misturados em diferentes proporções, e cuja homogeneidade da mistura é fundamental para o bom desempenho da resina como aglomerante no compósito.

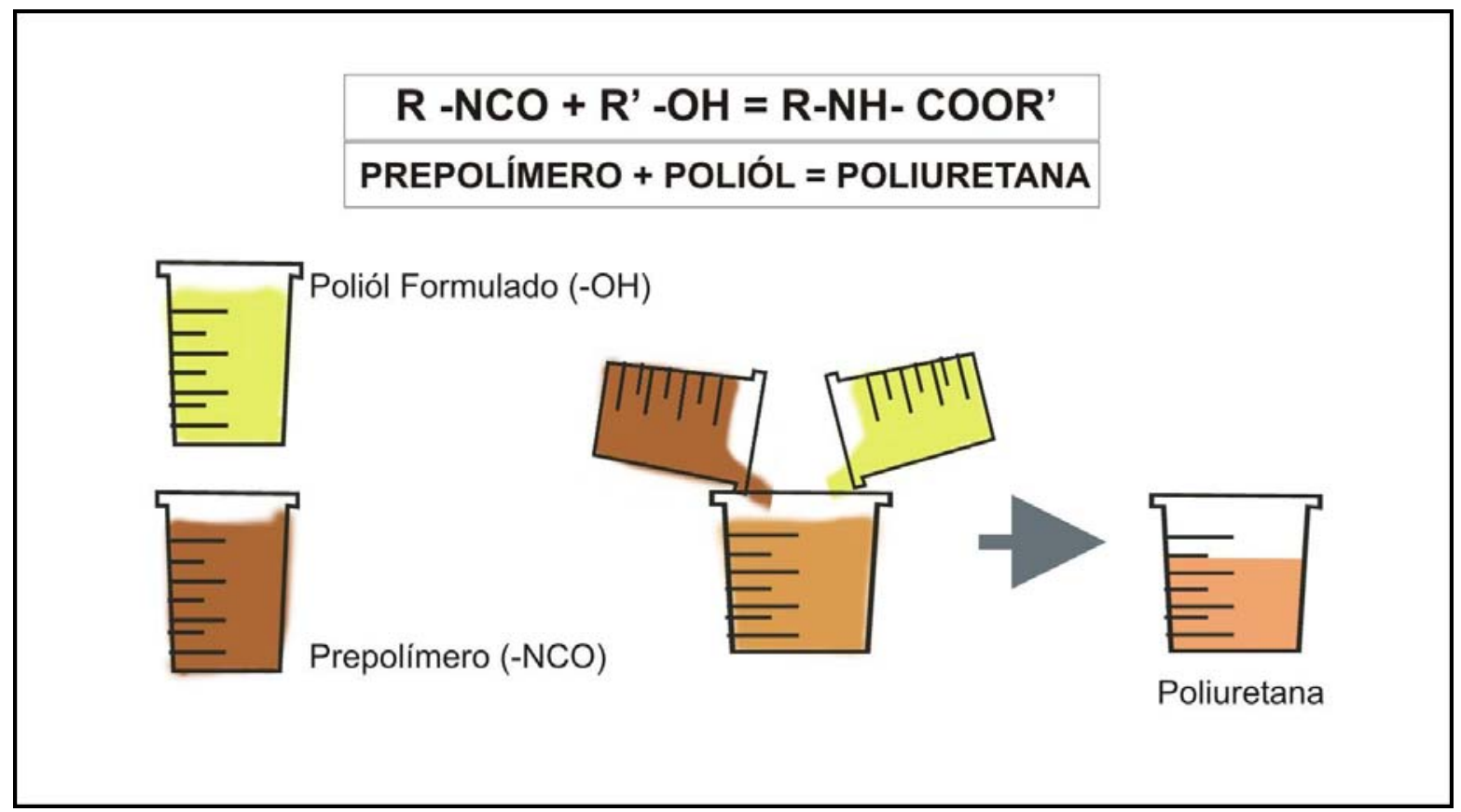

Figura 8.8 - Representação da formulação da resina para sua aplicação 


\subsubsection{Propriedades da Resina PU}

\subsubsection{Determinação da Densidade da Resina Polimerizada}

Este ensaio foi realizado no Instituto de Tecnologia e Pesquisa - INTEP em conformidade com a ASTM D792 - Density and Specific Gravity (Relative Density) of Plastics by Displacement.

Por se tratar de um material que não absorve água, a densidade foi obtida através da relação da massa e do volume de corpos-de-prova regulares feitos com a resina. A massa foi obtida em balança com precisão de $0,001 \mathrm{~g}$ e o volume, através de paquímetro com precisão de $0,01 \mathrm{~mm}$. A densidade, portanto, é o quociente da massa $(\mathrm{g})$ pelo volume $\left(\mathrm{cm}^{3}\right)$.

\subsubsection{Determinação da Resistência à Abrasão da Resina $P U$}

Este ensaio foi realizado no Departamento de Geotecnia - SGS, na Escola de Engenharia de São Carlos, de acordo com a BS 812. Trata-se de uma mesa giratória, movida por motor elétrico, e onde são colocados e fixados, em sua superfície, os corpos de prova, dois por seção, conforme pode ser visto na Figura 8.9. Enquanto a mesa gira, ela vai recebendo, ininterruptamente, uma quantia de areia segundo uma granulometria determinada, que vai formando uma película por onde o corpo de prova vai passar. $\mathrm{O}$ atrito entre corpo de prova e a areia faz com que o primeiro se desgaste. O ensaio está concluído quando a mesa completa um determinado número de rotações. Para se avaliar a resistência à abrasão, o corpo de prova é pesado antes e depois do ensaio. A partir dos valores obtidos, calcula-se o desgaste do corpo de prova em porcentagem. 

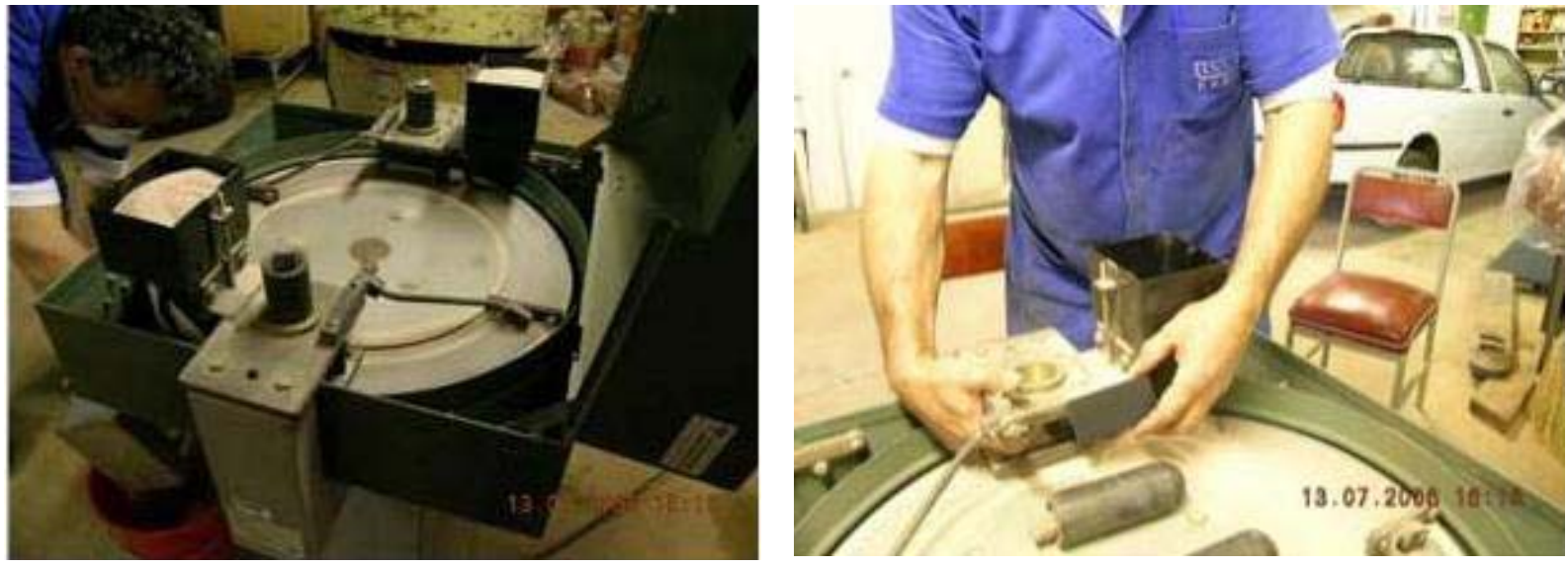

Figura 8.9 - Ensaio de desgaste à abrasão

Para a realização deste ensaio, foram moldados 4 corpos de prova de resina, com dimensões de $90 \mathrm{~cm}$ x $50 \mathrm{~cm} \times 2 \mathrm{~cm}$, além do preparo de uma areia com partículas de diâmetro entre $0,850 \mathrm{~mm}$ e $0,300 \mathrm{~mm}$, contendo pelo menos, $75 \%$ do total de partículas entre 0,600 mm e 0,425 mm.O número de revoluções do disco foi de 500 voltas.

\subsubsection{Ensaio de Tração}

Este ensaio foi realizado no Instituto de Química de São Carlos, no laboratório do Grupo de Química Analítica e Tecnologia de Polímeros, em conformidade com a ASTM D 638M for Tensile Properties of Plastics. Para a execução do ensaio são confeccionadas placas de resina com aproximadamente $3 \mathrm{~mm}$ de espessura e, a partir destas, recortados os corpos de prova com as dimensões especificadas na norma, com o uso de um molde metálico.

Para a moldagem das placas, o pré-polímero e o poliól foram pesados segundo o traço $1: 2$, respectivamente, e misturados manualmente por 3 minutos. Logo após, a mistura é submetida ao vácuo por 10 minutos, para se eliminar todo o ar incorporado, evitando a formação de bolhas. Só então, é despejado nas formas, previamente untadas vaselina.

Obtidos os corpos de prova, são tomadas as medidas de sua espessura e largura na região central, solicitada à tração, para o cálculo da área inicial. 
O ensaio consiste em solicitar à tração o corpo de prova, até o rompimento da seção estreita, e a Figura 8.10 ilustra o equipamento. A prensa registra a deformação causada pela aplicação da força de tração até a ruptura.

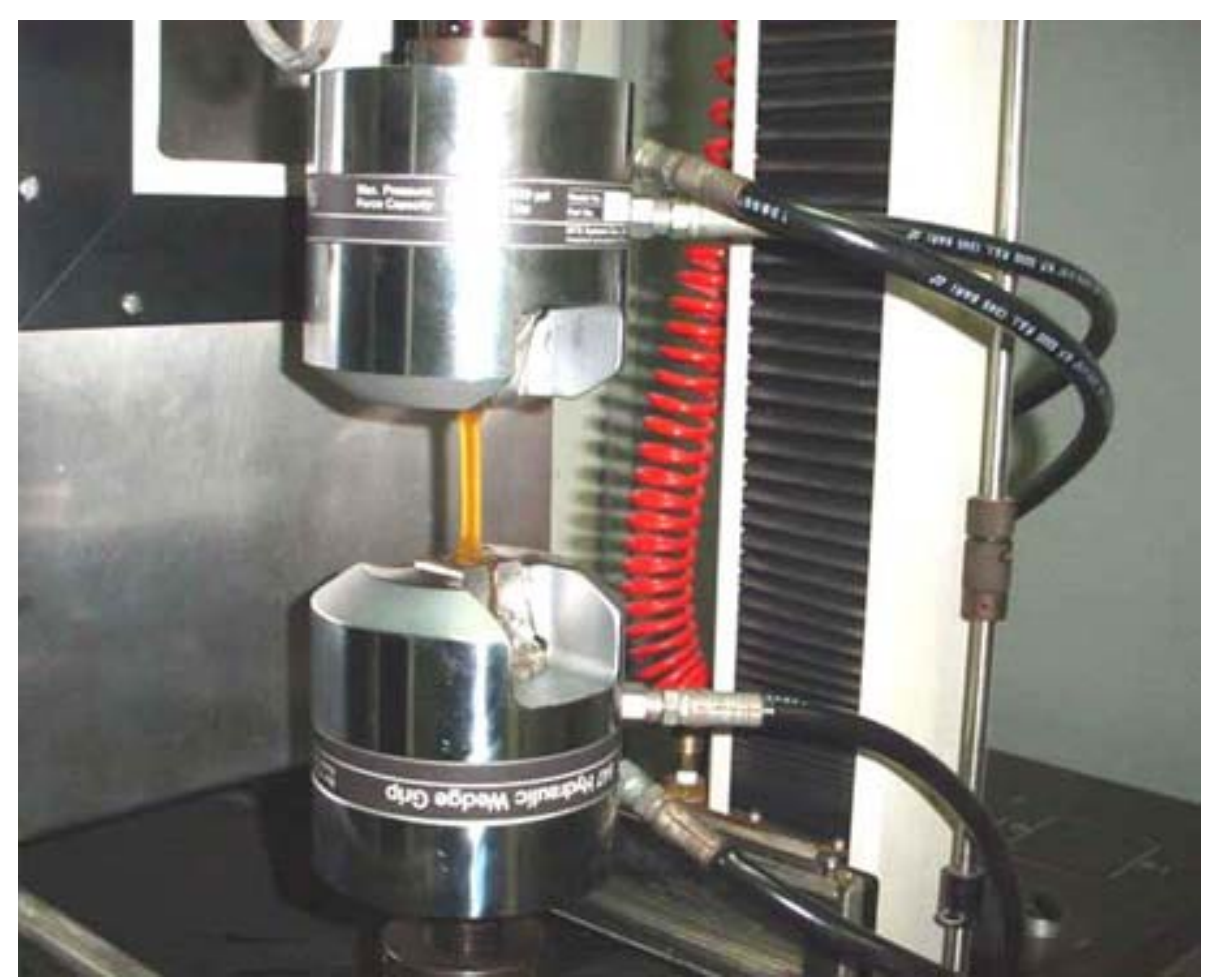

Figura 8.10 - Ensaio de tração em equipamento do GQATP- IQSC

As propriedades mecânicas obtidas são:

a) Resistência à tração $(\mathrm{MPa})$ : é obtida pela divisão da máxima força aplicada $(\mathrm{N})$ pela área inicial da seção transversal (mm2). O valor máximo da força se da quando ocorre a ruptura do corpo de prova na região de escoamento.

b) Alongamento na ruptura (\%): representa o aumento percentual do comprimento da peça sob tração, no momento da ruptura.

c) Módulo de elasticidade (MPa): é o quociente entre a tensão aplicada e a deformação, dentro do limite elástico, em que toda a deformação é reversível e proporcional a tensão. 


\subsubsection{Ensaio de Compressão}

Este ensaio foi realizado no Instituto de Química de São Carlos, no laboratório do Grupo de Química Analítica e Tecnologia de Polímeros, em conformidade com a ASTM D 695M for Compressive Properties of Rigid Plastics [Metric]. Para a execução do ensaio são confeccionados corpos de prova cilíndricos com $25 \mathrm{~mm}$ de diâmetro e $50 \mathrm{~mm}$ de altura.

O ensaio consiste em solicitar à compressão os corpos de prova, até o seu rompimento, que pode ser visível ou não, no caso de um rompimento interno. $\mathrm{O}$ equipamento registra a deformação causada pela aplicação da força. Na figura 8.11 esta constando o equipamento utilizado e o corpo de prova submetido à compressão.
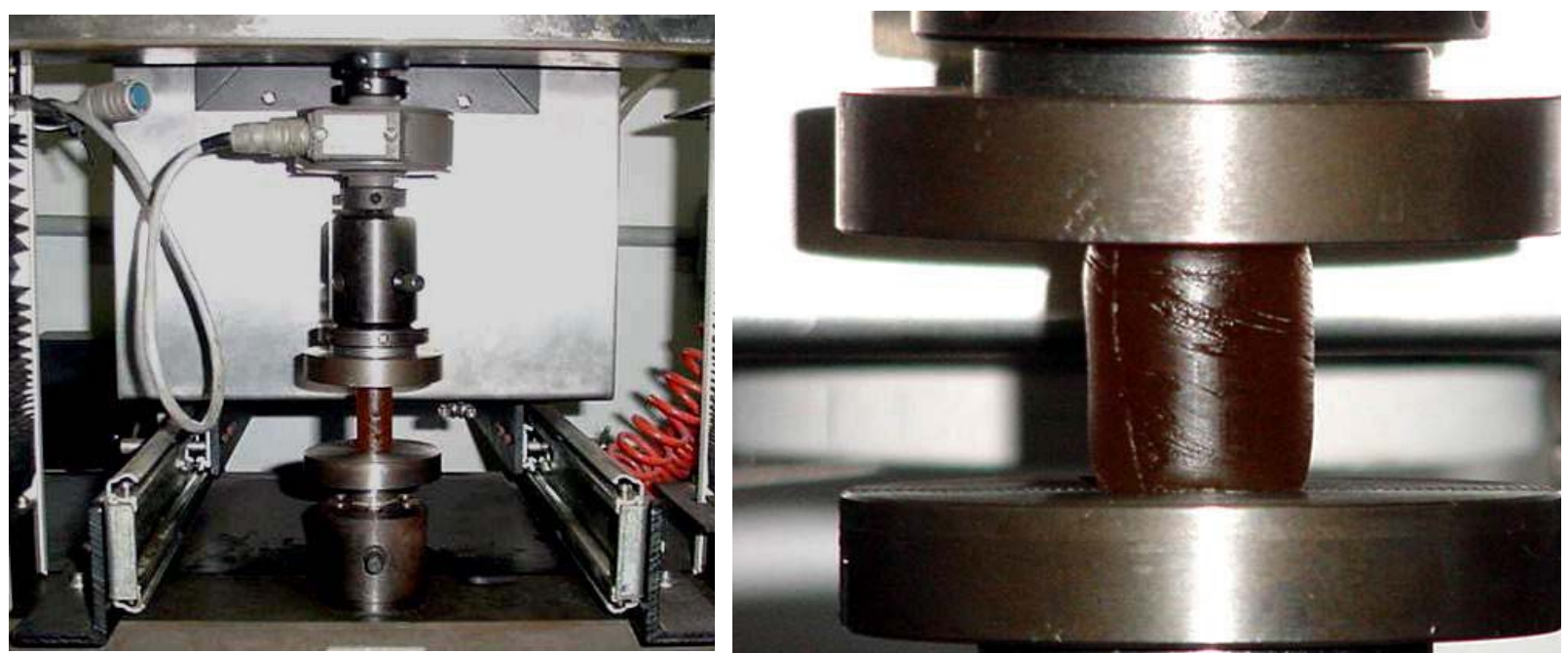

Figura 8.11 - Ensaio de compressão axial da resina poliuretana utilizada como aglomerante do compósito

As propriedades mecânicas obtidas são:

a) Resistência à compressão $(\mathrm{MPa})$ : é obtida pela divisão da máxima força aplicada (N) pela área inicial da seção transversal $\left(\mathrm{mm}^{2}\right)$. O valor máximo da força se dá quando ocorre a ruptura do corpo-de-prova. 
b) Diminuição na ruptura (\%): representa a diminuição percentual do comprimento da peça sob compressão, no momento da ruptura.

c) Módulo de elasticidade (Pa): é o quociente entre a tensão aplicada e a deformação, dentro do limite elástico, em que toda a deformação é reversível e proporcional a tensão.

\subsubsection{Ensaio de Resistência ao Intemperismo Artificial}

Este ensaio foi realizado no Laboratório de Construção Civil da Escola de Engenharia de São Carlos, em conformidade com a ASTM G 154 Operating Light and Water-Exposure Apparatus (Fluorescent UV-Condensation Type) for Exposure of Nonmetalic Materials, em equipamento desenvolvido pelo Prof. Osny Pellegrino Ferreira. O procedimento consiste na exposição acelerada do material sob análise em laboratório, onde os agentes degradantes (luz, calor e umidade) são controlados de maneira que simulem o ambiente natural. Entretanto, devido a esses fatores ambientais agirem na atmosfera de modo aleatório e imprevisível, não se pode esperar que o ensaio em laboratório reproduza fielmente as variações das intempéries naturais. Porém, as exposições em laboratório permitem explorações comparativas entre os corpos de prova submetidos ao intemperismo e os que não sofreram ataque.

Basicamente o aparelho de laboratório para o ensaio de intemperismo artificial é composto de oito lâmpadas de radiação ultravioleta, sistema de aspersão de água, controles de temperatura e umidade, controle de programação do ciclo e suporte dos corpos-de-prova. Estas partes são acopladas em uma câmara, permitindo que o pesquisador tenha a facilidade de operação dos controles de ajuste, colocação e troca dos corpos de prova e na manutenção do equipamento. 
São moldadas placas de resina poliuretana, com dimensões de $30 \times 7 \times 0,3 \mathrm{~cm}$, e colocadas no suporte de alumínio existente na câmara, de modo a sofrerem ciclos alternados de quatro horas de radiação ultravioleta e quatro horas de vapor de água sob temperatura controlada. Este suporte permite que o fluxo de vapor d'água transcorra pela superfície das placas e que a radiação ultravioleta incida sobre as mesmas.

Segundo a norma, as placas dispostas na área de exposição à radiação devem ser rotacionadas diariamente, de modo a atenuar as diferenças de radiação nesta área. $\mathrm{O}$ sentido de rotação adotado pode ser observado na figura 8.12.

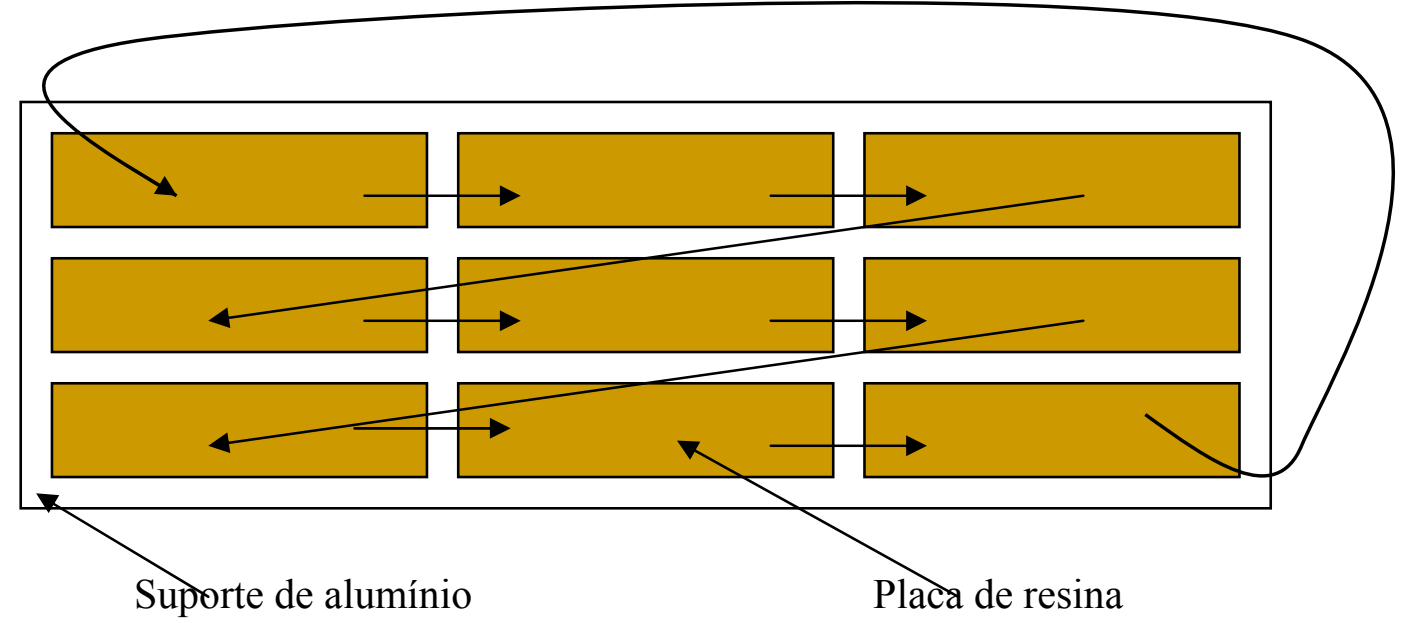

Figura 8.12 - Sentido da rotação das placas de resina no ensaio de intemperismo artificial

As placas ficam expostas ao intemperismo por um número de horas compatíveis. Após este tempo, são recortados os corpos-de-prova com o uso do molde, conforme a ASTM D 638M e, posteriormente, submetidos aos ensaios mecânicos e de dureza.

\subsubsection{Ensaio de Dureza}

Para o teste de dureza, realizado no Instituto de Química de São Carlos, no laboratório do Grupo de Química Analítica e Tecnologia de Polímeros, foi utilizado um durômetro 
Wultest, com ponta de prova para a escala Shore “A”, Modelo MP-2. Os ensaios de dureza, nas amostras de elastômeros PU, são feitos sempre na temperatura ambiente, seguindo-se o procedimento descrito pela norma ASTM D2240 Rubber Property - Durometer Hardness. Para cada tipo de amostra, é realizado o teste aplicando-se o durômetro em cinco pedaços diferentes, considerando-se o valor médio. Na Figura 8.13 é apresentado o equipamento utilizado neste ensaio.

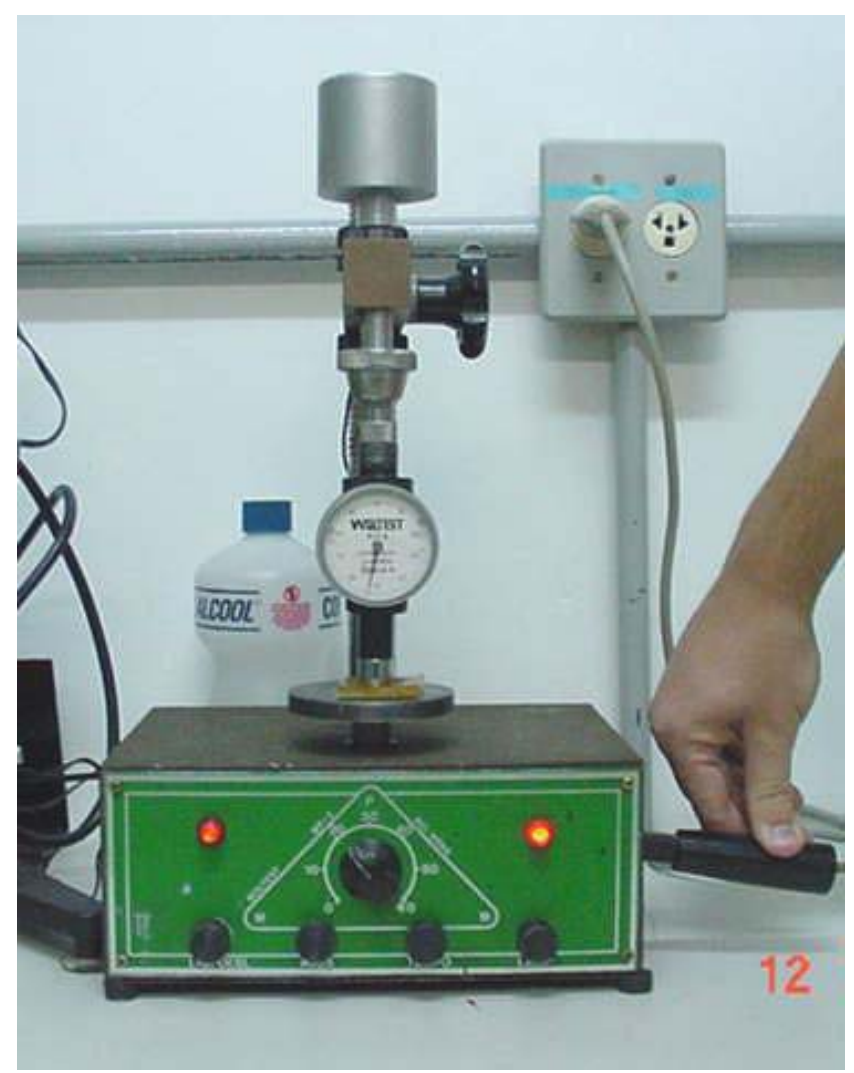

Figura 8.13 - Ensaio de dureza da resina PU

Os resultados dos ensaios de tração, compressão e dureza, para a avaliação das características da resina PU estão constando do capítulo 9, incluindo a sua perda de resistência após a resina ser submetida ao intemperismo artificial. 


\subsection{Compósito de PU e Borracha}

Os ensaios inicialmente realizados foram procedidos à temperatura ambiente. Posteriormente, foi observado que a polimerização obtida com elevação da temperatura possibilitava uma aceleração da cura e, por conseguinte liberação mais rápida das fôrmas utilizadas para a moldagem dos corpos de prova produzidos com o compósito.

Conforme foi referida anteriormente, no Capítulo 7 a opção pelo compósito utilizando a resina PU como aglomerante se justifica como uma forma alternativa de aproveitamento dos resíduos de pneus inservíveis aos métodos de regeneração existentes e que se baseiam na desvulcanização da borracha a partir da utilização de solventes orgânicos concomitante à aplicação de pressão e calor.

Estes métodos, além de consumirem uma quantidade significativa de energia calorífica para o aquecimento exigido pelo processo, acarretam uma considerável poluição do meio ambiente, pela liberação de materiais voláteis na atmosfera.

A utilização de PU de origem vegetal, ao contrário, representa a possibilidade de baixo consumo energético e a eliminação de riscos ambientais na constituição de compósitos a partir de resíduos de pneus inservíveis.

Para produção do compósito proposto neste trabalho foi utilizado o dispositivo desenvolvido para aquecimento das fôrmas metálicas, com capacidade para elevação de temperatura da temperatura até $300^{\circ} \mathrm{C}$.

A mistura da resina PU com as partículas de borracha foi procedida manualmente, iniciando-se com a mistura dos dois componentes da resina segundo a relação $1: 2 \mathrm{em}$ massa (pré-polímero : poliol). A Figura 8.14 apresenta a mistura resina x borracha e sua colocação no molde. 

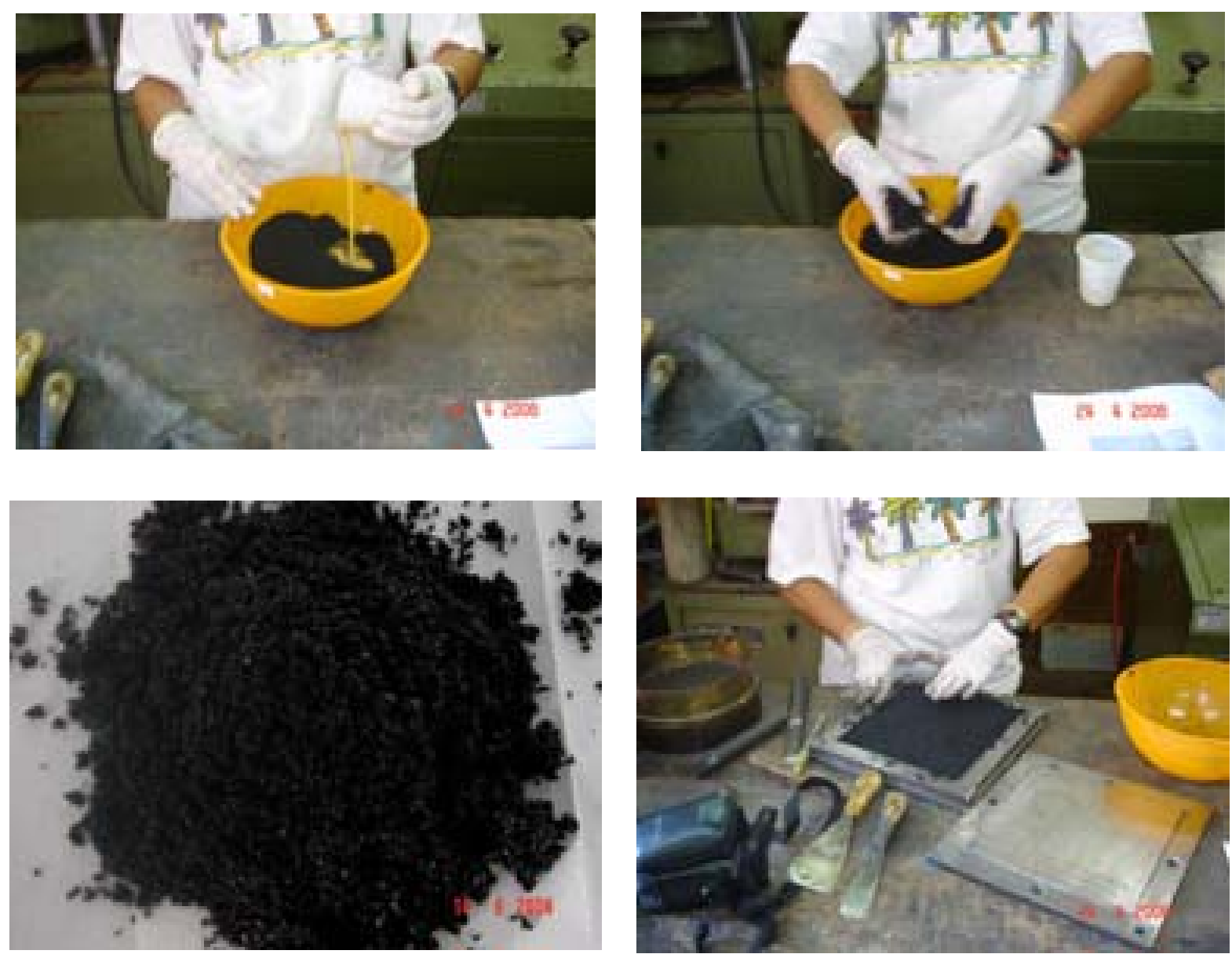

Figura 8.14 - Seqüência da mistura de partículas de borracha e a resina PU, e sua moldagem na fôrma metálica

Além da necessidade de incremento de temperatura, a aplicação de compressão no molde é uma exigência para obtenção do compósito. Para isso foi desenvolvido um dispositivo adaptável à prensa existente no INTEP, e que permitiu o aumento de temperatura, concomitante ao controle da pressão.

A Figura 8.15 apresenta a prensa com o dispositivo instalado, onde o incremento da temperatura foi conseguido com a liberação de calor gerado por uma resistência elétrica, comandada por um controlador de temperatura ligado a um termopar, instalado entre as faces do prato da prensa. 


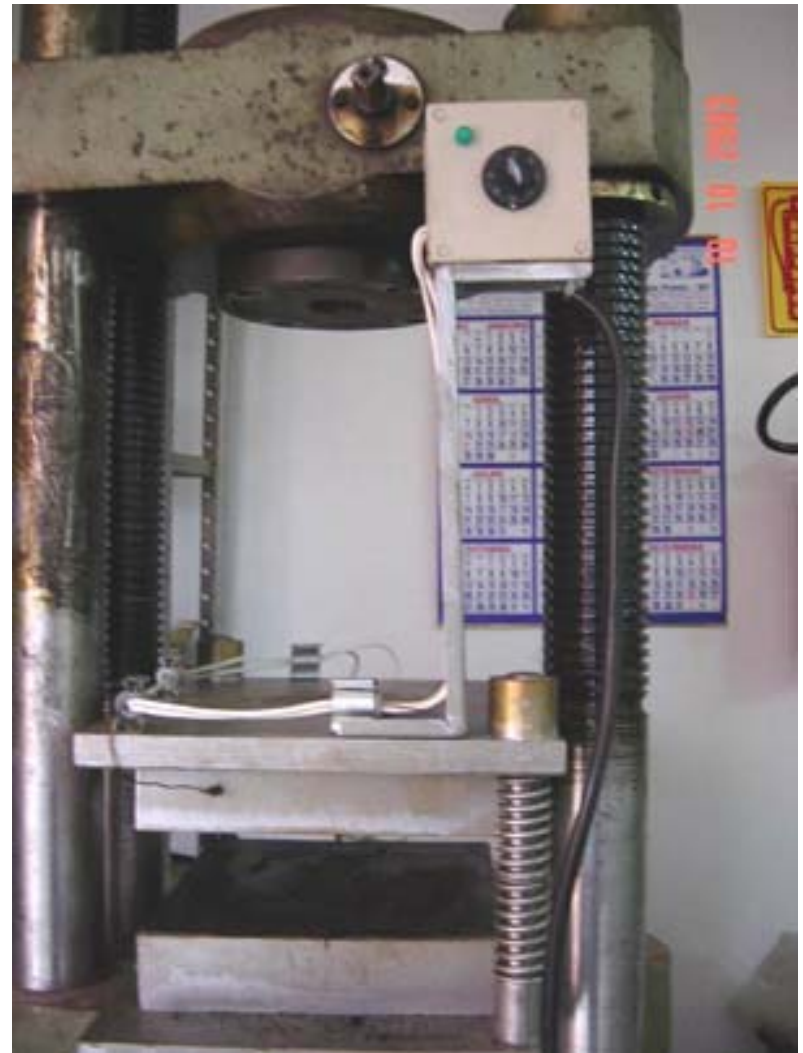

Figura 8.15 - Dispositivo de aquecimento da fôrma, acoplado à prensa

\subsubsection{Ensaios dos Compósitos de Resina PU e Borracha}

\subsubsection{Microscopia Eletrônica de Varredura (MEV)}

As fotomicrografias de MEV foram realizadas no IQSC, obtidas em um equipamento LEO (modelo 440) com detector OXFORD, operando com feixe de elétrons de $20 \mathrm{kV}$. As amostras foram recobertas com $20 \mathrm{~mm}$ de ouro em um metalizador Coating System BALTEC MED 020 e mantidas em dessecador até o momento de análise. As primeiras moldagens do compósito borracha x PU foram observadas através do MEV, como uma forma de analisar a interação partícula de borracha e resina, especialmente da zona de interfaciamento: partícula de borracha x resina PU, onde a adesão entre ambas é fundamental para a obtenção de um compósito com propriedades adequadas. 
As imagens obtidas, variando-se as relações entre resina e partículas de borracha, e também a temperatura, durante a etapa de moldagem, possibilitou eleger as melhores formulações e o processo de moldagem mais adequado.

O ensaio de MEV permitiu a avaliação dos diferentes compósitos investigados, tornando possível uma melhor análise da microestrutura interna do compósito (ligação resina/borracha). Assim, pode-se definir as proporções resina PU/Borracha mais adequadas ao compósito em estudo. A execução dos ensaios mecânicos que se seguiram ficou restrita aos compósitos considerados os mais viáveis, em termos de desempenho.

As imagens obtidas, variando-se as relações entre resina e partículas de borracha, e também a variação de temperatura, durante a etapa de moldagem, possibilitou eleger as melhores formulações e o processo de moldagem mais adequado para o compósito em estudo.

\subsubsection{Ensaio de compressão}

Este ensaio foi realizado no Instituto de Química de São Carlos, no laboratório do Grupo de Química Analítica e Tecnologia de Polímeros. Os corpos de prova moldados dessa maneira puderam ter sua densidade variada em função da quantidade de material (borracha + resina) previamente lançada no interior de cada inserto da fôrma. Foram construídos diferentes moldes para a produção de corpos de prova necessários aos ensaios mecânicos. Para a determinação da resistência à compressão foi desenvolvida uma fôrma cilíndrica contendo vários insertos, de modo que o material era colocado em seu interior e em seguida compactado segundo uma pressão determinada, concomitante ao aumento de temperatura do molde. 
A Figura 8.16 apresenta a fôrma adotada para a moldagem dos corpos de prova ensaiados à compressão e determinação do seu módulo de deformação, conforme a ASTM D $695 \mathrm{M}$.
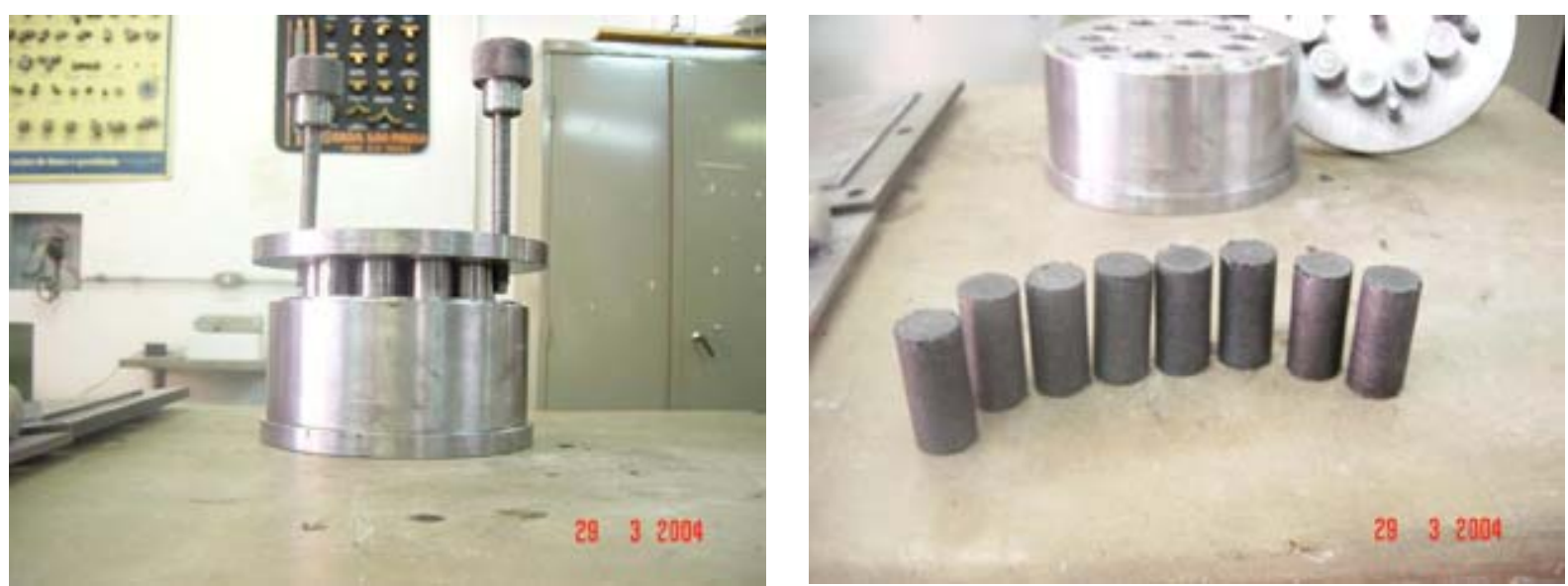

Figura 8.16 - Forma cilíndrica e corpos de prova do ensaio à compressão

O dispositivo constante da Figura 8.16 permite a moldagem de corpos de prova cilíndricos nas dimensões de $25 \mathrm{~mm}$ de diâmetro e altura de $50 \mathrm{~mm}$, com a densidade do compósito determinada mediante o controle do volume de material colocado em cada orifício.

Para evitar a aderência do material nas faces da fôrma aplicou-se pó de grafite, e em seguida a fôrma era aquecida para acelerar a polimerização da resina PU, após o que os corpos de prova eram retirados, removendo-se a tampa e a parte inferior.

A Figura 8.17 apresenta o ensaio realizado com o equipamento localizado no IQSC, Laboratório do Grupo de Tecnologia de Polímeros. 


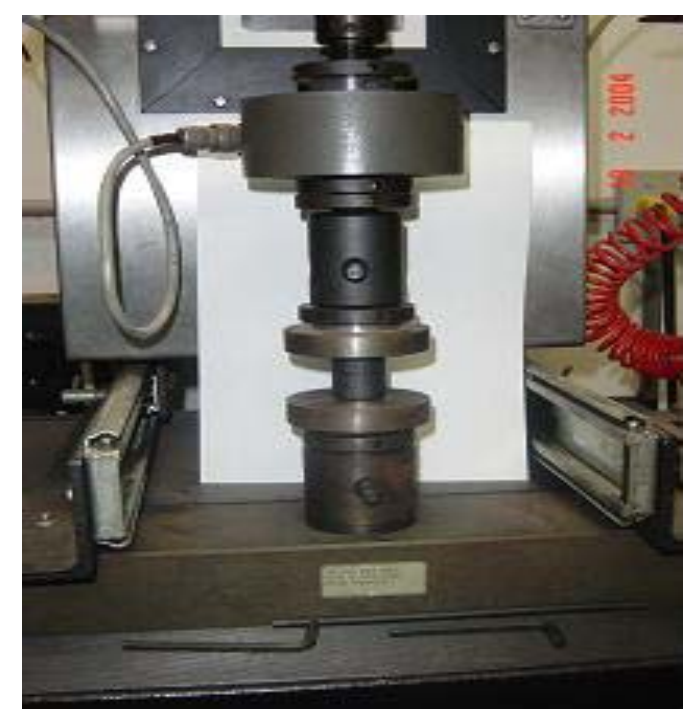

Figura 8.17 - Corpo de prova sendo ensaiado à compressão axial

\subsubsection{Ensaio de Tração}

Este ensaio foi realizado no Instituto de Química de São Carlos, no laboratório do Grupo de Química Analítica e Tecnologia de Polímeros. Para a execução dos ensaios de determinação da resistência à tração foi também necessário o desenvolvimento de moldes metálicos com a possibilidade de comprimir o material introduzido na fôrma, concomitante ao seu aquecimento.

Foi elaborada, inicialmente, a moldagem de placas planas e que foram posteriormente cortadas segundo a conformação de gravatas. Este método não surtiu bons resultados, o que levou a optar-se por fôrmas metálicas de modo a que a "gravata" já era moldada diretamente e com a conformação final, eliminado a necessidade de corte.

A Figura 8.18 apresenta o dispositivo e os corpos de prova moldados para realização dos ensaios à tração segundo a ASTM D 638M. 

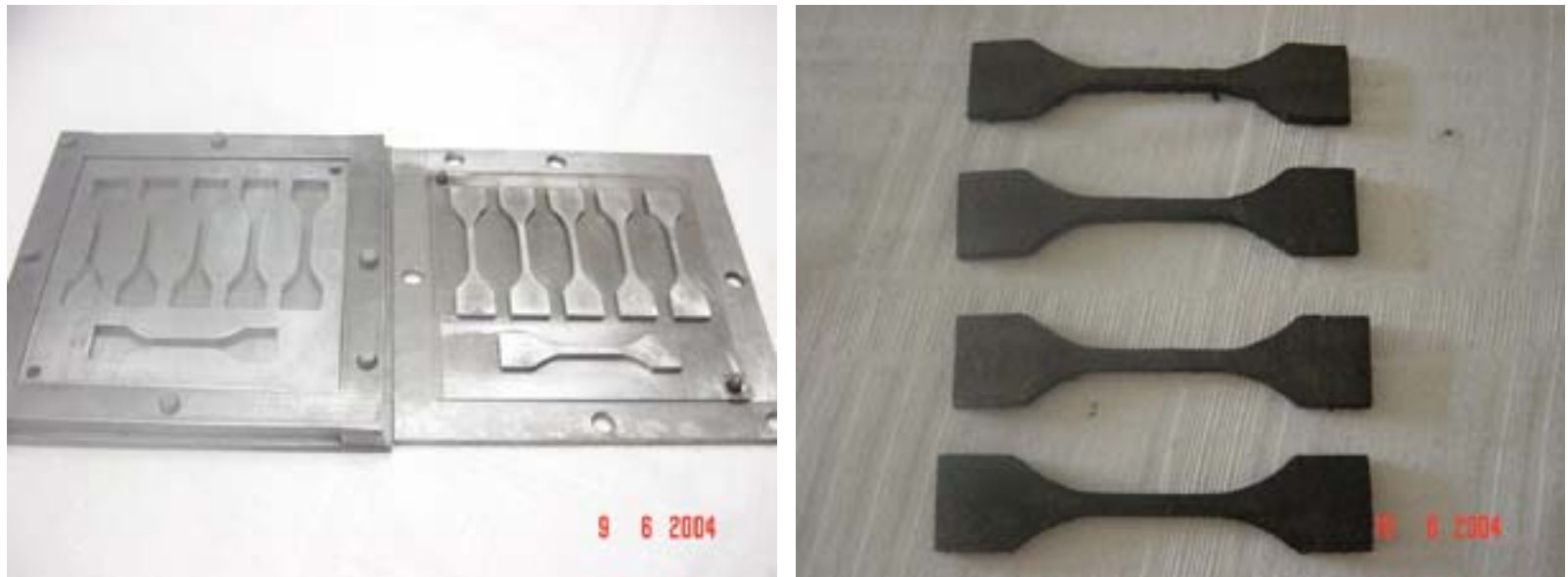

Figura 8.18 - Fôrma utilizada para moldagem do corpo de prova do ensaio à tração e gravatas utilizadas no ensaio

A Figura 8.19 mostra a garra da máquina de ensaio no momento da ruptura de um corpo de prova, à tração.

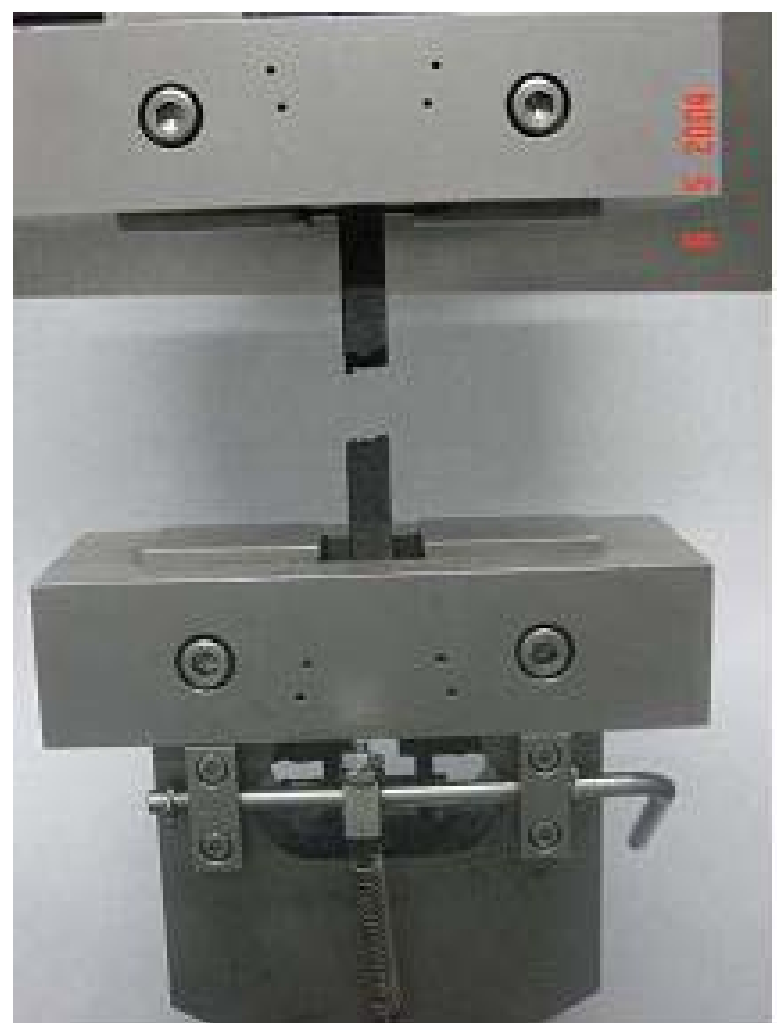

Figura 8.19 - Garras do equipamento e corpo de prova rompido à tração

Os valores de ruptura à tração obtidos nos ensaios inicialmente realizados, com base em corpos de prova de dimensões reduzidas concordes com ASTM D 638 M, não propiciaram 
bons resultados em razão da seção transversal recomendada aos corpos de prova utilizados para materiais poliméricos.

O que se fez, então, foi dobrar as dimensões dos corpos de prova, conseguindo-se assim uma maior seção transversal e menor variabilidade dos resultados.

\subsubsection{Ensaio de Rasgamento}

Este ensaio foi realizado com o intuito de melhor analisar a aderência das partículas de borracha à resina PU. Estes testes foram efetuados no DEMA, UFSCar, segundo as normas ASTM D624-00 e 1- "Standard test Method for tear Strenght of conventional vulcanized rubber and thermoplastic elastomers" e D1004-94a (2003) - "Standard test Method for initial tear resistance of plastic film and sheeting”.

Os corpos de prova foram obtidos a partir de placas dos compósitos, por meio de dispositivo de corte com a forma adequada. A Figura 8.20 apresenta o dispositivo de ensaio e o corpo de prova.
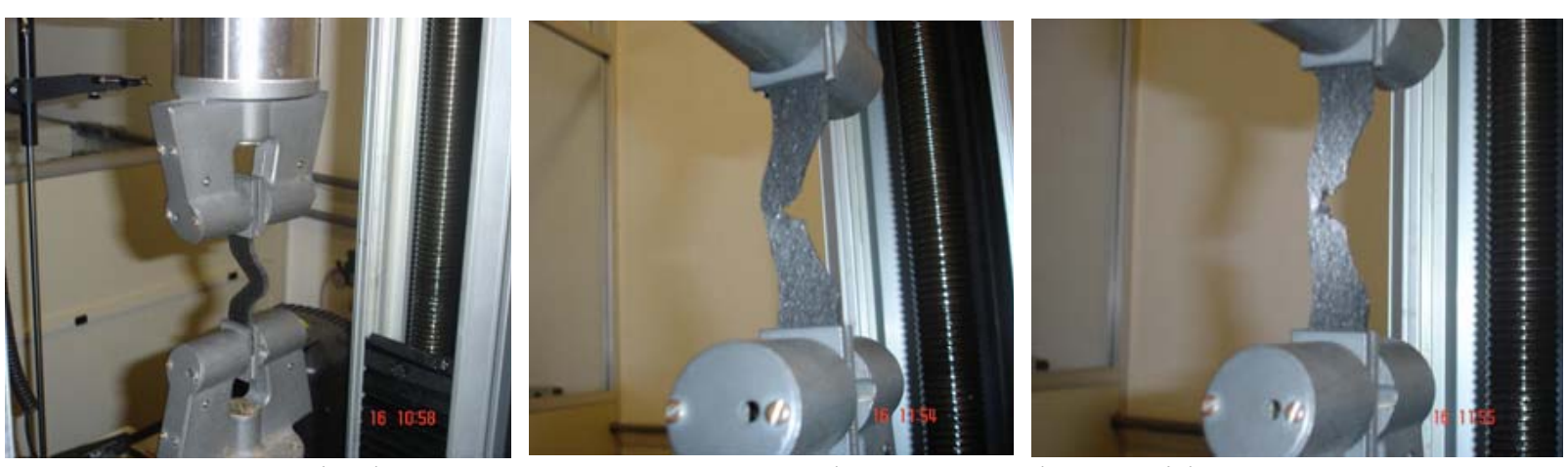

Figura 8.20 - Ensaio de rasgamento com o corpo de prova sendo rompido

\subsubsection{Resistência ao Fogo}

Estes testes foram efetuados no DEMA, UFSCar. A borracha é um material que apresenta uma inflamabilidade significativa quando exposta ao calor intenso. Esta propriedade 
constitui-se como um dos fatores negativos à sua utilização em determinadas condições de exposição a altas temperaturas. O ensaio de inflamabilidade foi realizado de acordo com a norma UL - 94, horizontal, e o resultado obtido esta constando do Capítulo 9.

\subsubsection{Determinação da Resistência à Abrasão}

A norma ASTM D5963-04 "Standard Test Method for Rubber Property - Abrasion Resistance (Rotary Drum Abrader)” permite a determinação da resistência à abrasão de borrachas e elastômeros em geral variando o diâmetro do disco, sendo que o material abrasivo é constituído por uma lixa de gramatura padrão adequada. Este ensaio, todavia, não foi possível de ser realizado, o que levou a buscar outra alternativa para esta avaliação.

Assim, foi verificada a resistência à abrasão do compósito com base no ensaio realizado inicialmente com a resina PU, utilizando o aparelho constante da norma BS 812, disponível no Departamento de Geotecnia da EESC - USP.

Na Figura 8.21 apresenta-se o corpo de prova preparado com a placa de compósito colada a uma chapa de madeira. Enquanto o disco de desgaste gira, ele vai recebendo, ininterruptamente, uma quantia de areia segundo uma granulometria determinada, que vai formando uma película por onde o corpo de prova vai se atritar, acarretando o desgaste. O ensaio está concluído quando a mesa completa um determinado número de rotações. Para se avaliar a resistência à abrasão, o corpo de prova é pesado antes e depois do ensaio. A partir dos valores obtidos, calcula-se o desgaste do corpo de prova em porcentagem. A figura a seguir, mostram detalhes dos exemplares submetidos ao ensaio. 

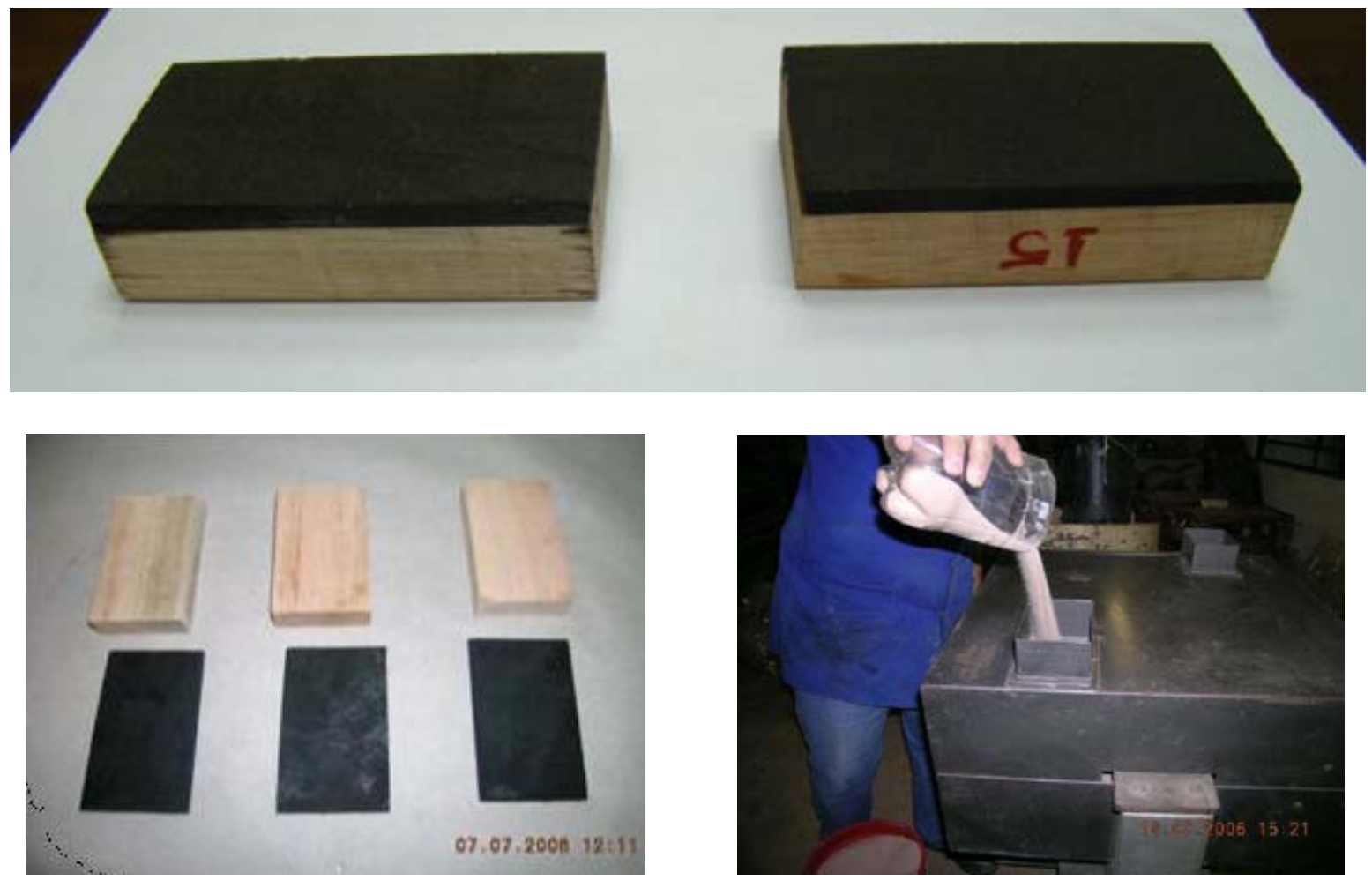

Figura 8.21 - Ensaio de desgaste à abrasão

\subsubsection{Ensaio de Resistência ao Intemperismo Artificial}

Este ensaio é realizado em conformidade com a ASTM G 154 Operating Light and Water-Exposure Apparatus (Fluorescent UV-Condensation Type) for Exposure of Nonmetalic Materials. Foi adotado mesmo procedimento utilizado para Resina PU, o qual consiste na exposição acelerada do material sob analise em laboratório, onde os agentes degradantes (luz, calor e umidade) são controlados de maneira que simulem o ambiente natural. Entretanto, devido a esses fatores ambientais agirem na atmosfera de modo aleatório e imprevisível, não se pode esperar que o ensaio em laboratório reproduza fielmente as variações das intempéries naturais. Porém, as exposições em laboratório permitem explorações comparativas entre os corpos de prova submetidos ao intemperismo e os que não sofreram ataque.

O aparelho de laboratório para o ensaio de intemperismo artificial é composto de oito lâmpadas de radiação ultravioleta, sistema de aspersão de água, controles de temperatura e 
umidade, controle de programação do ciclo e suporte dos corpos-de-prova. Estas partes são acopladas em uma câmara, permitindo que o pesquisador tenha a facilidade de operação dos controles de ajuste, colocação e troca dos corpos de prova e na manutenção do equipamento.

Foram moldadas placas de resina poliuretana, com dimensões de $30 \times 7 \times 0,3 \mathrm{~cm}$, e colocadas no suporte de alumínio existente na câmara, de modo a sofrerem ciclos alternados de quatro horas de radiação ultravioleta e quatro horas de vapor de água sob temperatura controlada. Este suporte permite que o fluxo de vapor d'água fique em contato com a superfície das placas e que a radiação ultravioleta incida sobre as mesmas.

Segundo a norma, as placas dispostas na área de exposição à radiação devem ser rotacionadas diariamente, de modo a atenuar as diferenças de radiação nesta área. $\mathrm{O}$ sentido de rotação adotado pode ser observado na figura 8.22.

As placas ficam expostas ao intemperismo pelo tempo que se considerou conveniente. A Figura 8.22 apresenta a câmara de intemperismo empregada no ensaio.
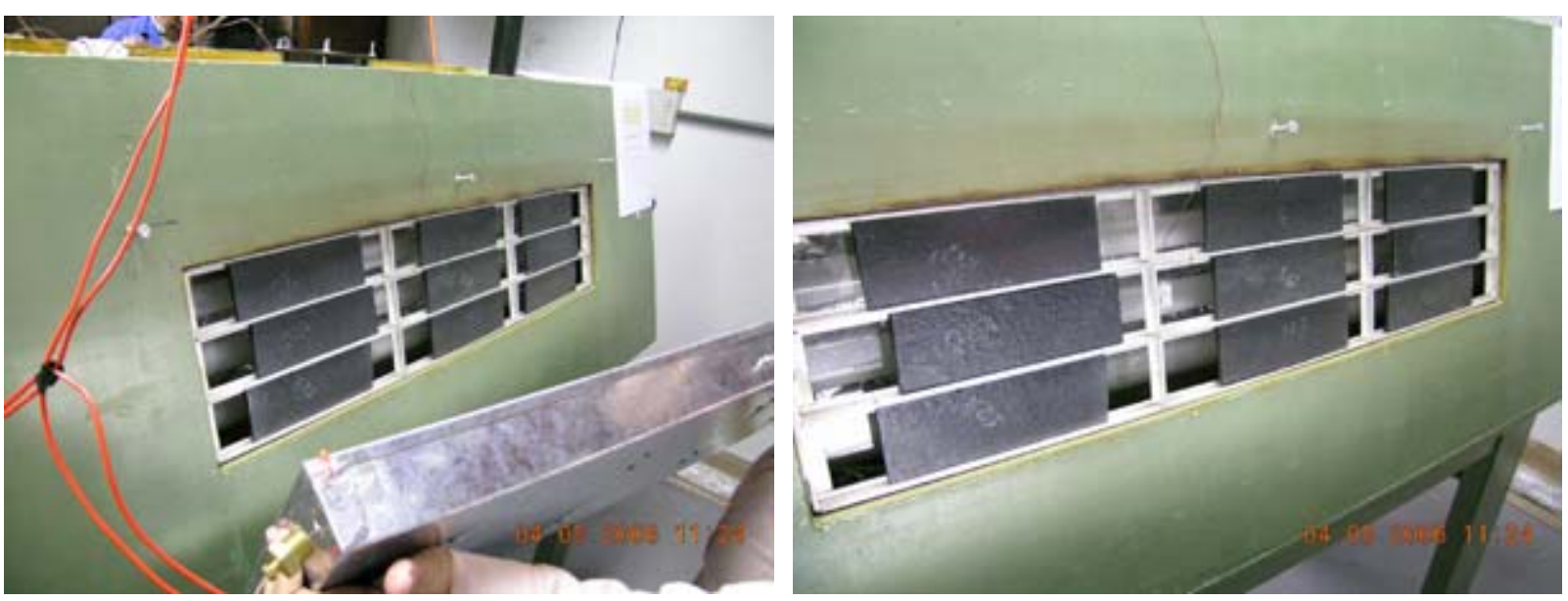

Figura 8.22 - Câmara de raios UV com os corpos de prova colocados 


\subsubsection{Ensaio de Dureza}

Estes testes foram efetuados no Instituto de Química de São Carlos, no laboratório do Grupo de Química Analítica e Tecnologia de Polímeros.

Este ensaio foi realizado utilizando o mesmo equipamento adotado para a avaliação da dureza da resina PU, no traço 1 (pré-polímero) : 2 (poliol), sempre à temperatura ambiente, segundo a ASTM D 2240-9 7 for Rubber Property- Durometer Hardeness.

\subsubsection{Determinação da Densidade}

Este ensaio foi realizado segundo a ASTM D 792 - Density and Specific Gravity (Relative Density) of Plastics by Displacement, com os mesmos procedimentos adotados para a resina $\mathrm{PU}$, realizados anteriormente.

A densidade foi obtida através da relação entre massa e volume dos corpos de prova, por meio de uma balança com precisão de $0,001 \mathrm{~g}$ e através de paquímetro com precisão de 0,01mm, para determinação das suas dimensões.

\subsubsection{Análise Dinâmico Mecânica (DMA)}

A análise dinâmico mecânica (DMA), realizada nos compósitos ensaiados, permite determinar inúmeros parâmetros correspondentes às propriedades mecânicas, elásticas e plásticas, e a temperatura de máximo pico do compósito (Tan $\delta$ ou $\mathrm{Tg}$, que corresponde a temperatura de transição vítrea do material).

O equipamento utilizado para esta análise pertence ao IQSC - USP, e consistiu de um DMA 983 acoplado a um termoanalizador TGA 2100 (TA Instruments), sendo o ensaio 
conduzido no modo de flexão, com freqüência fixa de $1 \mathrm{~Hz}$, e deformação compatível, de modo a não ultrapassar sua região de viscoelasticidade linear, e razão de aquecimento de $5^{\circ} \mathrm{C} / \mathrm{min}$. com ensaios sub-ambientes $\left(-80\right.$ à $50^{\circ} \mathrm{C}$ ) utilizando um LNCA (Liquid Nitrogen Cooling System), também da TA Instruments ${ }^{6}$.

Para estes ensaios de DMA, os corpos de prova foram retirados da própria placa do compósito produzido, após serem submetidos à prensagem e calor, com as dimensões de 250 $\mathrm{mm}$ x $250 \mathrm{~mm}$. Após a polimerização das placas, os corpos de prova foram cortados nas dimensões de $70 \mathrm{~mm}$ x 13mm x 5mm, conforme se pode ver nas Figura. 8.23 e 8.24.
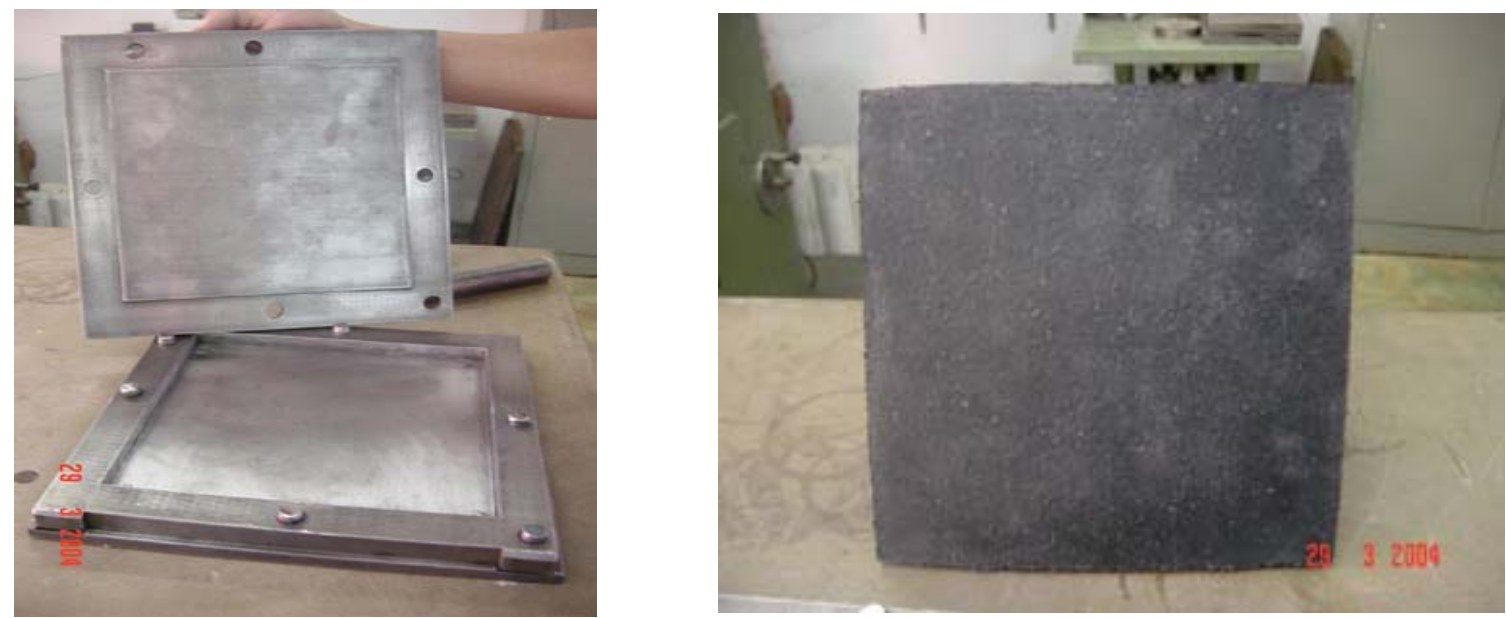

Figura 8.23 - Fôrma da placa recém moldada do compósito
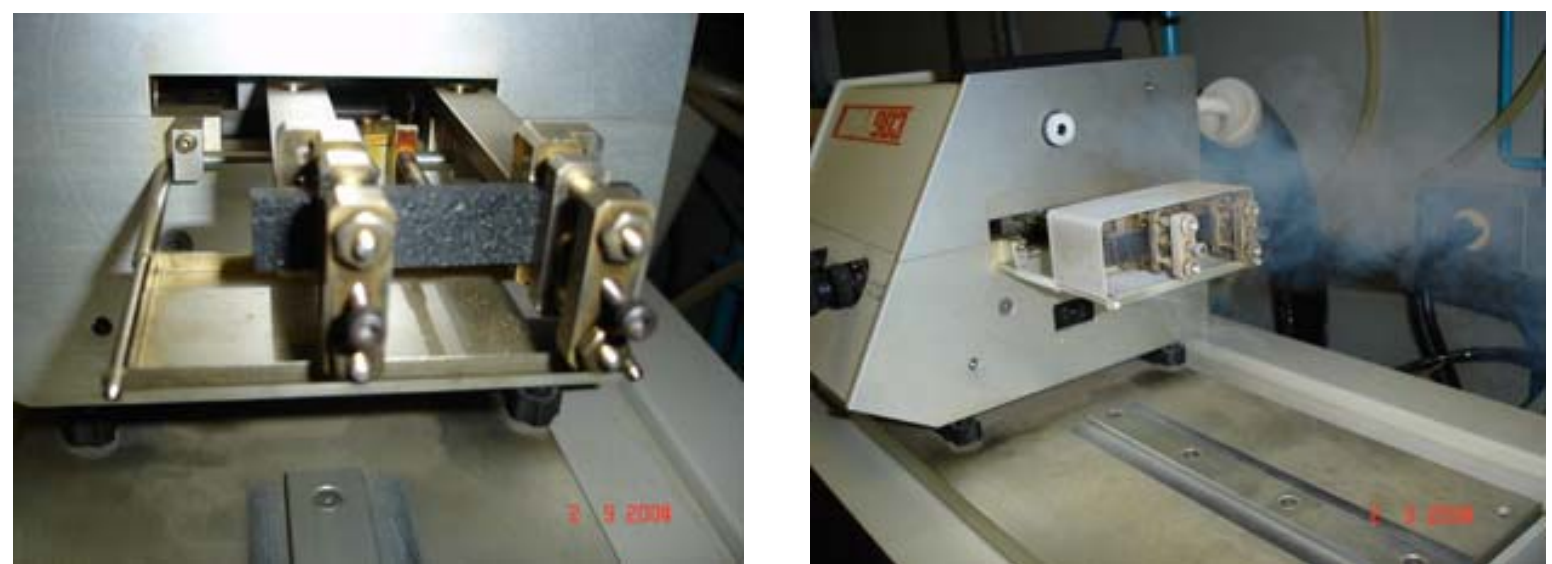

Figura 8.24 - Corpo de prova submetido a ensaio de DMA, mostrando a injeção de $\mathrm{N}_{2}$ para resfriamento a $-80^{\circ} \mathrm{C}$

\footnotetext{
${ }^{6}$ TA Instruments - Fabricante de equipamentos para termo-análises.
} 
O ensaio de DMA é conduzido por flexão (HATAKEYAMA; QUINN, 1994). Com ele se permite a análise de materiais, com possibilidade de determinar parâmetros como o módulo de elasticidade de armazenamento (E'), as propriedades elásticas, o módulo de elasticidade de Perda (E'), as propriedades Plásticas, e a temperatura de transição vítrea do compósito $(\tan \delta)$.

Neste trabalho promoveu-se o resfriamento dos corpos de prova a uma temperatura de $-80^{\circ} \mathrm{C}$, com nitrogênio líquido, e depois o aquecimento até $50^{\circ} \mathrm{C}$, com rampa de $5^{\circ} \mathrm{C}$ por minuto, para determinação da temperatura de transição vítrea.

A Figura 8.24 mostra detalhe do equipamento, com o corpo de prova preso nas hastes que vibram na freqüência e amplitude especificada para o ensaio.

No Capítulo 9 são apresentadas as curvas encontradas para os compósitos analisados.

\subsubsection{Termogravimetria (TG)}

A técnica de TG foi utilizada para avaliar a estabilidade e a decomposição térmica dos compósitos obtidos, da borracha e da resina poliuretana pura, em função da perda de massa, quando submetidas a uma variação de temperatura.

Estes testes foram efetuados no Instituto de Química de São Carlos, no laboratório do Grupo de Química Analítica e Tecnologia de Polímeros.

Foi utilizado um analisador termogravimétrico TA Instruments, modelo SDT, e o ensaio realizado em um módulo simultâneo TG-DTA da TA Instruments, modelo Q600, na faixa de temperatura de 25 a $1000{ }^{\circ} \mathrm{C}$, com massas de amostra de $10 \mathrm{mg}$, sob atmosfera dinâmica de ar (vazão de $100 \mathrm{~mL} \mathrm{~min}^{-1}$ ) e razão de aquecimento de $10^{\circ} \mathrm{C} \mathrm{min}^{-1}$.

Na Figura 8.25 se pode observar a seqüência realizada para analise TG 

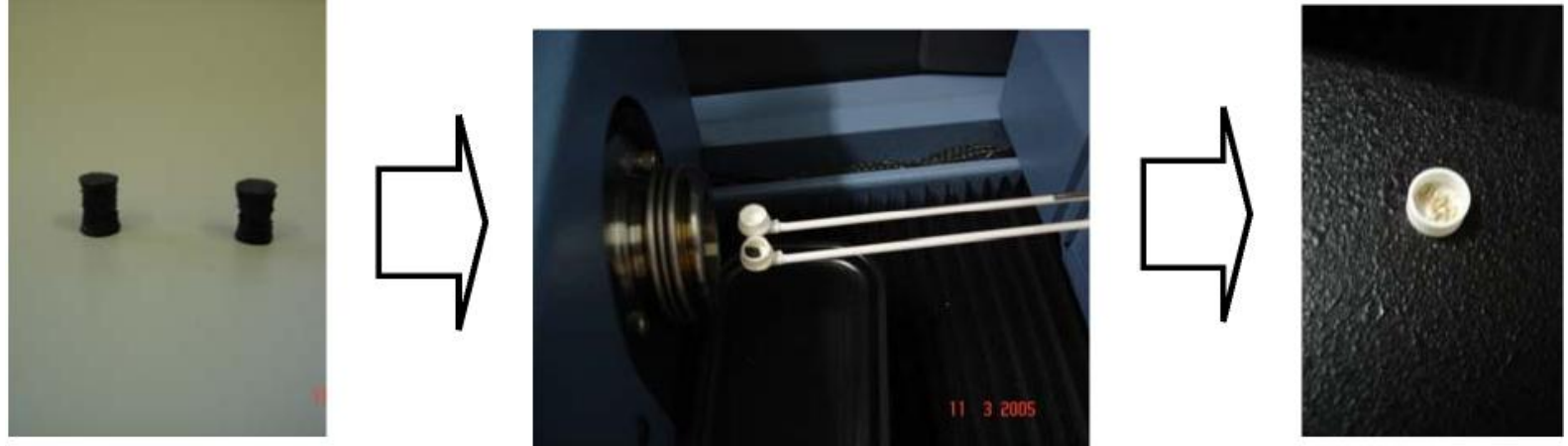

Figura 8.25 - Corpo de prova para ensaio de TG e resíduo final

Os resíduos obtidos nos ensaios termogravimétricos realizados com a borracha foram caracterizados por espectroscopia na região do infravermelho como sendo sulfato de zinco, o qual está relacionado com a oxidação do enxofre, presente na composição da borracha após a queima do resíduo (negro de fumo). Na Figura 8.26 está colocada a preparação das amostras ensaiadas no equipamento pertencente ao Instituto de Química de São Carlos - USP. Os espectros de absorção na região do infravermelho foram feitos em pastilhas de $\mathrm{KBr}$ em um Espectrofotômetro de infravermelho Nicolet Modelo 5SXC-FTIR com resolução de $4 \mathrm{~cm}^{-1}$.
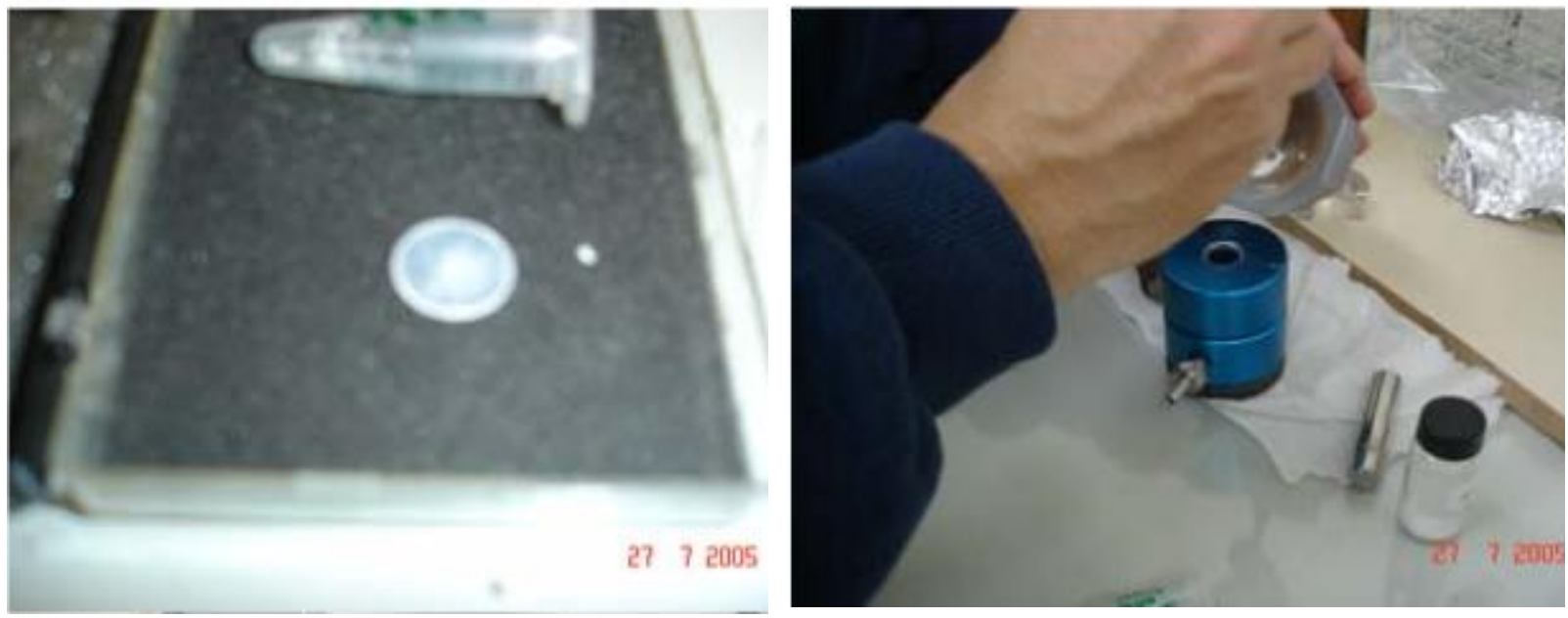

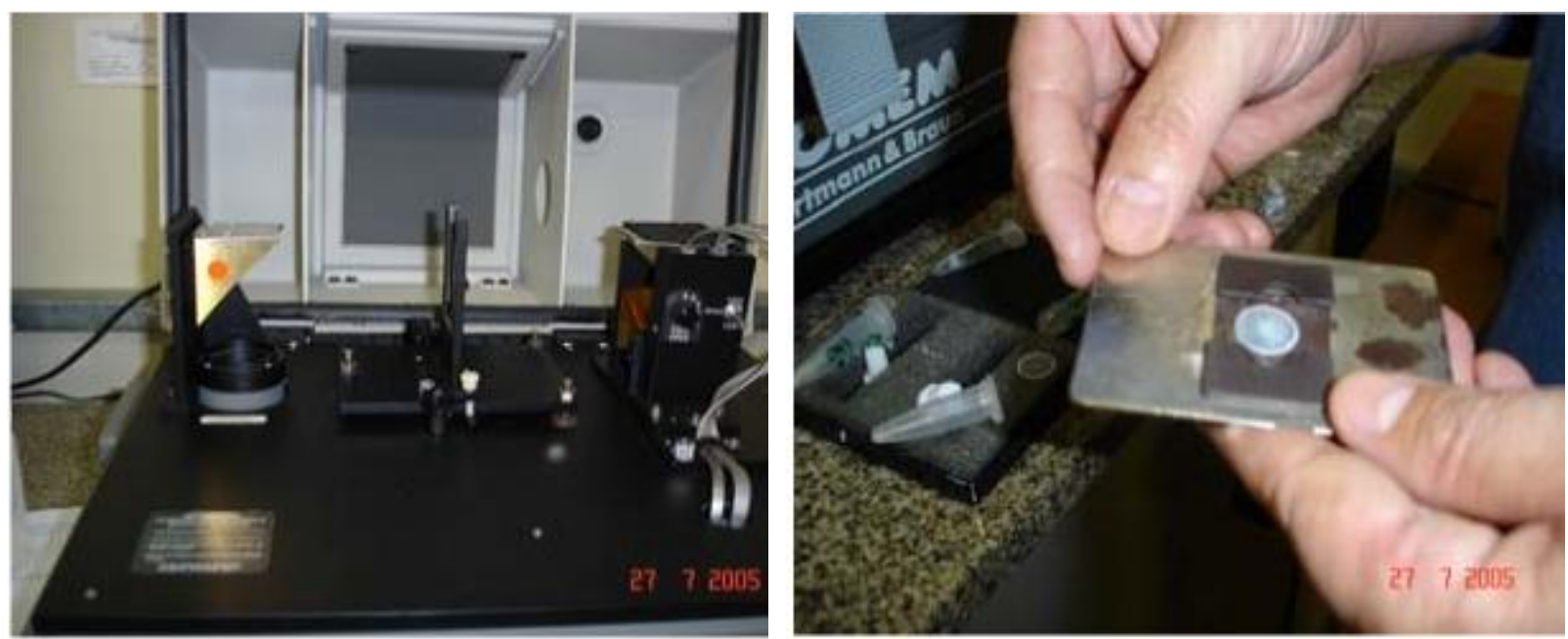

Figura 8.26 - Equipamento e preparação dos corpos de prova utilizados no ensaio infravermelho

\subsubsection{Resistência ao Impacto - Ensaio Charpy}

Componentes ou elementos, quaisquer que sejam suas aplicação, sempre estão sujeitos a esforços estáticos e/ou dinâmicos que podem resultar danos, levando o material a falhas prematuras. O carregamento dinâmico, ou por impacto, tem particular importância de ser analisado, pois, sob elevadas taxas de deformação, a fratura do material pode ocorrer de modo preferencialmente frágil.

Estes testes foram efetuados no Departamento de Materiais da EESC - USP, e para a determinação da resistência ao impacto pelo método Charpy foram utilizados corpos de prova com dimensões de $60 \mathrm{~mm}$ de comprimento, $13 \mathrm{~mm}$ de largura e $4 \mathrm{~mm}$ de espessura. Nos corpos de prova foi feito entalhe em V (2 mm de profundidade, $45^{\circ}$ e corda de $0,25 \mathrm{~mm}$ ), e foram resfriados à $-50^{\circ} \mathrm{C}$ por meio de imersão controlada em nitrogênio líquido e álcool.

Apesar da sua grande aplicabilidade, deve-se ter em mente que o ensaio de impacto não fornece parâmetros absolutos do material. Os resultados obtidos devem ser aplicados considerando-se a dimensão e geometria do corpo de prova utilizado. Os resultados do ensaio de impacto Charpy são apresentados em $\mathrm{kj} / \mathrm{m}^{2}$. 
O ensaio foi realizado em uma máquina de impacto modelo PSd 50/15 - Heckert, e a figura 8.27 apresenta a preparação das amostras resfriadas com nitrogênio líquido, em uma caixa plástica, para possibilitar a execução do ensaio.
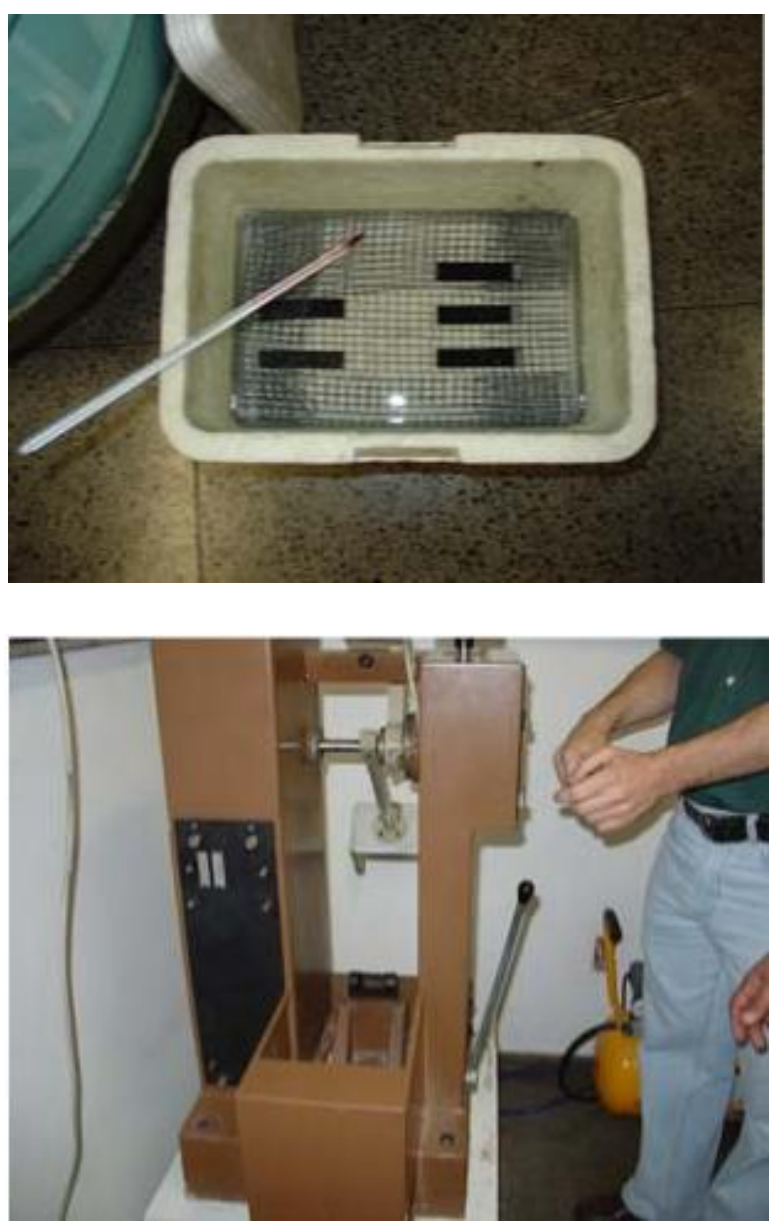

Figura 8.27 - Preparação das amostras em N2 e detalhes do equipamento de ensaio

O deslocamento do pêndulo acarreta a ruptura do corpo de prova, expondo sua seção transversal a uma condição interessante, pois além do equipamento acusar a energia despendida, fica possível visualizar a distribuição das partículas de borracha. A figura 8.28 apresenta a seção de um corpo de prova, onde se pode observar as partículas de borracha cortadas, denotando sua boa aderência a resina PU. 


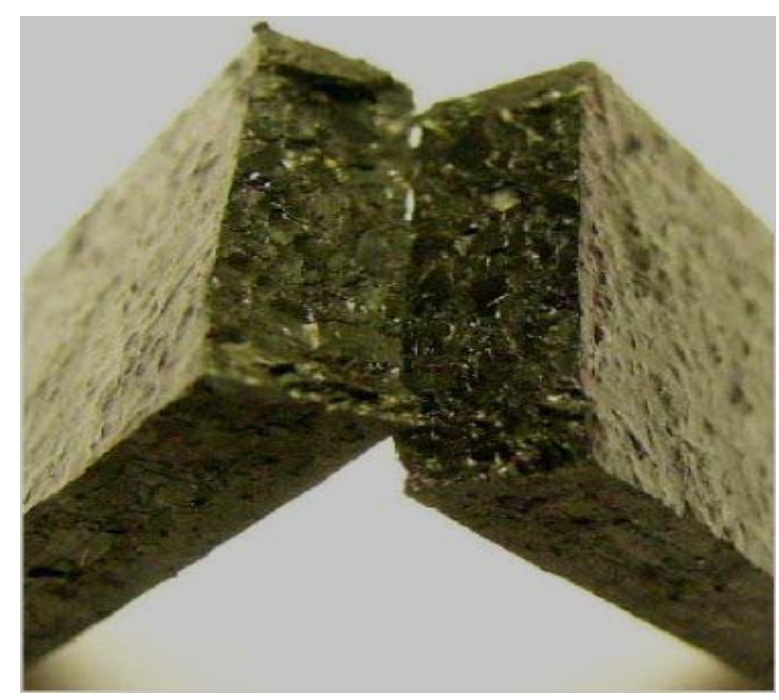

Figura 8.28 - Seção de ruptura de um corpo de prova submetido ao ensaio Charpy

\subsubsection{Ensaio de Resistividade Elétrica}

Este ensaio foi executado no Departamento de Eletricidade da EESC - USP, e possibilita a determinação da capacidade de isolamento às cargas elétricas, de um material que se queira determinar a resistividade elétrica. Para esta avaliação se adota o procedimento do ensaio elétrico preconizado segundo os parâmetros constantes da NBR 6936: Técnicas de ensaios elétricos em alta tensão.

Utilizaram-se três corpos de provas com diâmetro de $10 \mathrm{~cm}$ e aproximadamente $2 \mathrm{~mm}$ de espessura.

Outro parâmetro, também importante, consiste na determinação da rigidez dielétrica em um campo elétrico máximo que o material suporta. O ensaio elétrico para determinação da rigidez elétrica é normalmente adotado do tipo tempo curto, em que se aumenta a tensão elétrica aplicada a partir do zero, com taxa uniforme em 10 e 20 segundos, em média.

O esquema da montagem para medição da rigidez dielétrica consiste de um equipamento de rigidez dielétrica (transformador regulável com indicador de corrente de fuga), eletrodo superior, eletrodo inferior, corpo de prova, cuba de vidro com óleo isolante de 
transformador, e as condições de temperatura e umidade relativa devem ser da ordem de $28,1^{\circ}$ C e $62 \%$ respectivamente. A Figura 8.29 apresenta o corpo de prova e o aparelho para medir resistividade deste corpo de prova, e os resultados estão constando do capítulo 9.
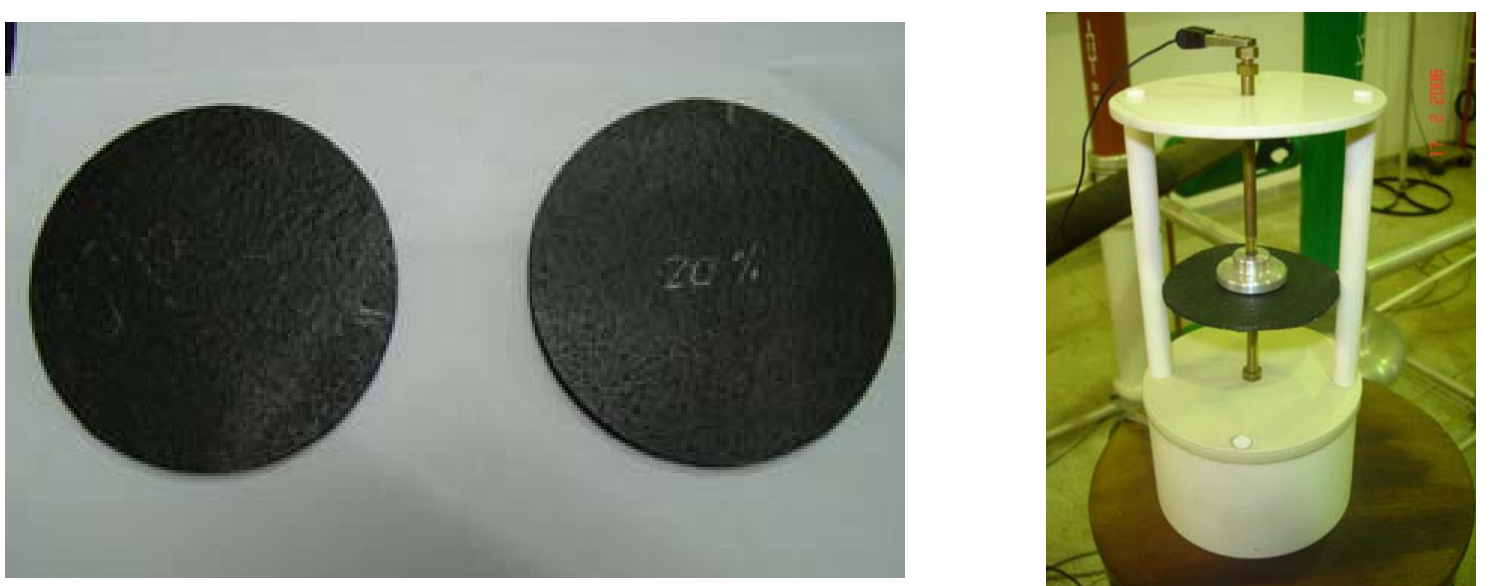

Figura 8.29 - Amostras ensaiadas e aparelho para medir resistividade do corpo

\subsubsection{Ensaio de Resistência aos Raios Ultra-Violeta}

Este ensaio foi realizado de forma análoga ao executado com a resina PU, todavia substituiu-se os ensaios mecânicos à tração por ensaios de DMA, avaliando-se as amostras novas e as demais, submetidas ao envelhecimento acelerado na câmara de UV.

A opção pelo ensaio de DMA pode ser justificada em razão de que possibilita uma avaliação muito mais acurada de desempenho do material compósito do que no caso de ensaios mecânicos, em escala macroscópica.

Através do DMA torna-se possível avaliar a degradação dos diferentes compósitos desenvolvidos neste trabalho, e ainda, simular o seu desempenho sob ação de variações de temperatura, pela alternância de freqüência e amplitude.

Estas condições permitem que, através da análise da fluência do material, se determine o seu desempenho a um prazo estendido. Dessa forma se pode, comparando os materiais em 
estudo, com materiais já conhecidos, avaliar as propriedades dos primeiros, tal como se procede com os ensaios de envelhecimento acelerados.

\subsubsection{Fluência do compósito (Creep -DMA)}

O ensaio de DMA permite a avaliação da deformabilidade dos polimeros quando estes são submetidos a um carregamento, variando-se a temperatura e a freqüência da aplicação da carga. A determinação da fluência dos polímeros permite avaliar seu comportamento quando submetidos à ação de uma carga constante em que o módulo de elasticidade tende a decrescer com o tempo. As Figuras 8.30 e 8.31 apresentam as curvas de um polímero submetido ao ensaio.

Isto ocorre porque o polímero sob carga tende a sofrer um rearranjo na sua estrutura molecular de maneira a minimizar as tensões localizadas neste ponto onde ocorre a aplicação da carga.

Resumindo, o estudo da fluência com o emprego do DMA permite explorar as propriedades, a longo prazo, do material obtendo o seu comportamento sob influencia da carga e do tempo considerados.

O creep estuda a particularidade do material submetido a uma carga constante por um período de tempo à uma temperatura desejada. Essa medida é muito interessante pois quantificará o decréscimo da eslaticidade do material. Obtendo as curvas master do material pode-se avaliar, com propriedade, o módulo de elasticidade durante vários anos de uso e assim determinar o prazo de validade do mesmo e o momento em que deverá ser substituído.

A curva master pode ser usada por exemplo para determinar o tempo ou a freqüência com a qual uma mangueira de borracha leva para romper após obter um determinado valor em 
sua compliance. O tempo que ela leva para obter a compliance critica, a uma dada temperatura pode ser facilmente estabelecido por meio da curva master. ${ }^{7}$

Curvas masters são obtidas mediante a interpolação de resultados dos ensaios dos corpos de prova submetidos à variação de parâmetros como o módulo de perda e de armazenamento, por efeito da variação de temperatura ao longo do ensaio. Conforme Figura 8.30 por meio de uma temperatura de referência constrói-se a curva máster do polimero.

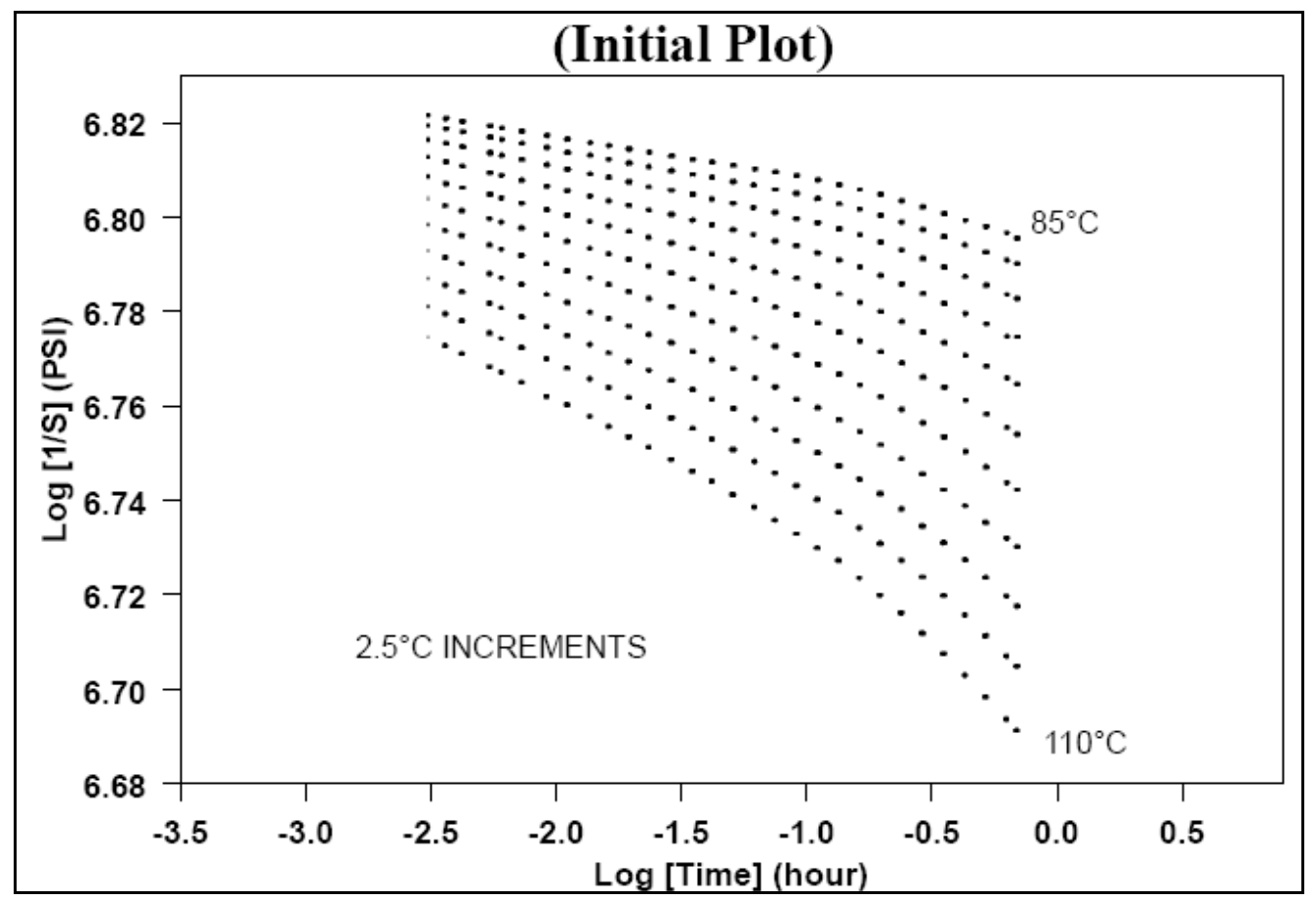

Figura 8.30 - Curvas de um polímero submetido ao ensaio DMA

\footnotetext{
${ }^{7}$ Catálogo da TA Instruments, Inc.’Thermal Analisis Technical Literature (Theory \& Applications)”
} 


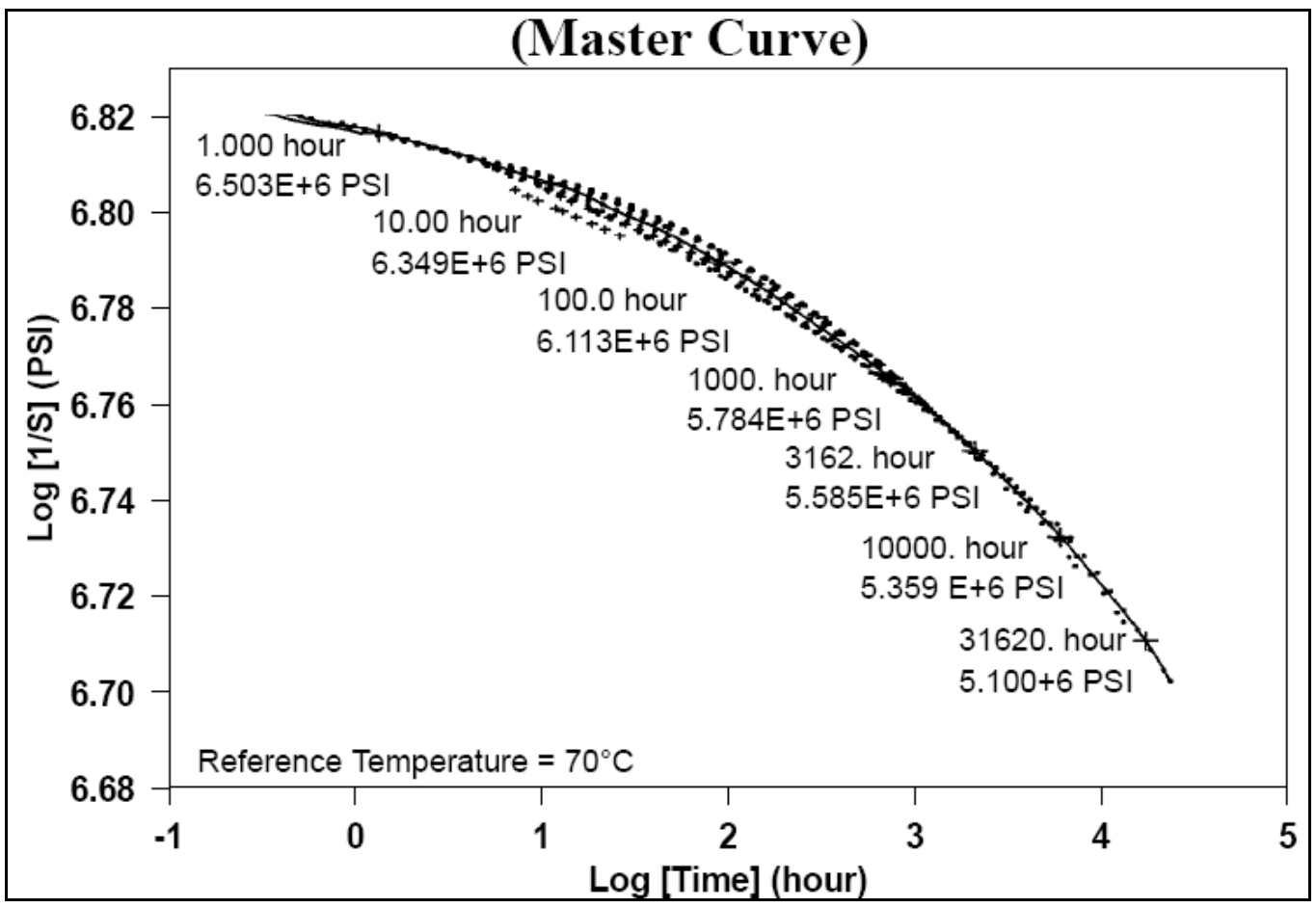

Figura 8.31 - Exemplo da construção da curva máster

Fonte: TA instruments Therminal Analysis \& Rheology

\subsubsection{Equação de Arrhenius (Viscoelasticidade do Material)}

A equação de Arrhenius, constante na Figura 8.32, é usada para descrever a viscoelasticidade do material e para obter a energia de ativação relacionado a transição vítria.

Ea $=$ energia de ativação 


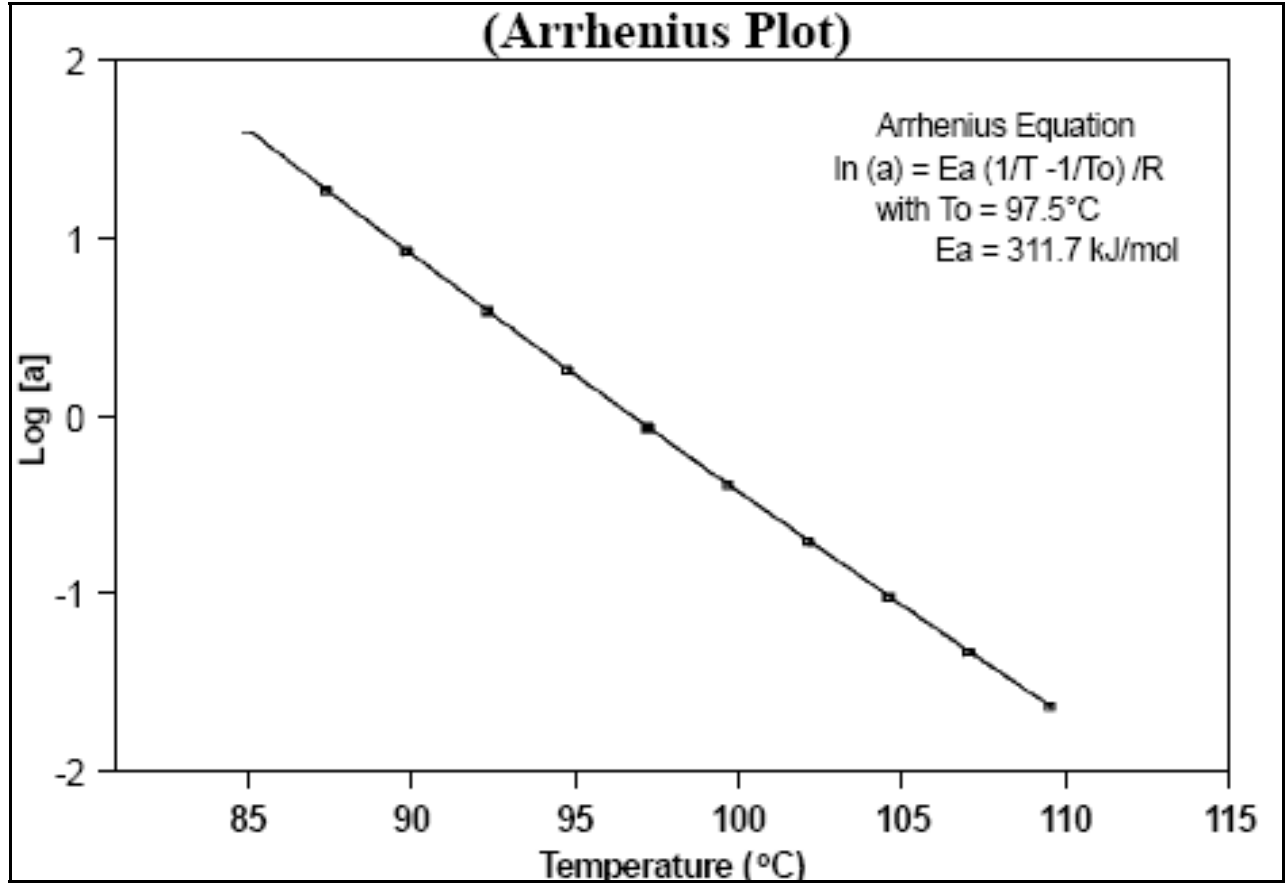

Figura 8.32 - Curva relativa a Equação de Arrhenius

\subsubsection{Equação de Williams-Landel-Ferry (WLF)}

A equação WLF correlaciona as propriedades de viscosidade dos materiais amorfos que estão entre a $\operatorname{Tg}$ (temperatura de transição vítrea) e aproximadamente $100-150^{\circ} \mathrm{C}$ acima da Tg. A Figura 8.33 apresenta a curva segundo a equação de WLF.

Para temperaturas com $150^{\circ} \mathrm{C}$ acima da $\mathrm{Tg}$, os efeitos sobre a fluência são insignificantes e a equação de Arrhenius melhor descreve a viscosidade dos materiais. A Figura 8.34 representa genericamente a curva correspondente aos intervalos onde valem as equações citadas 


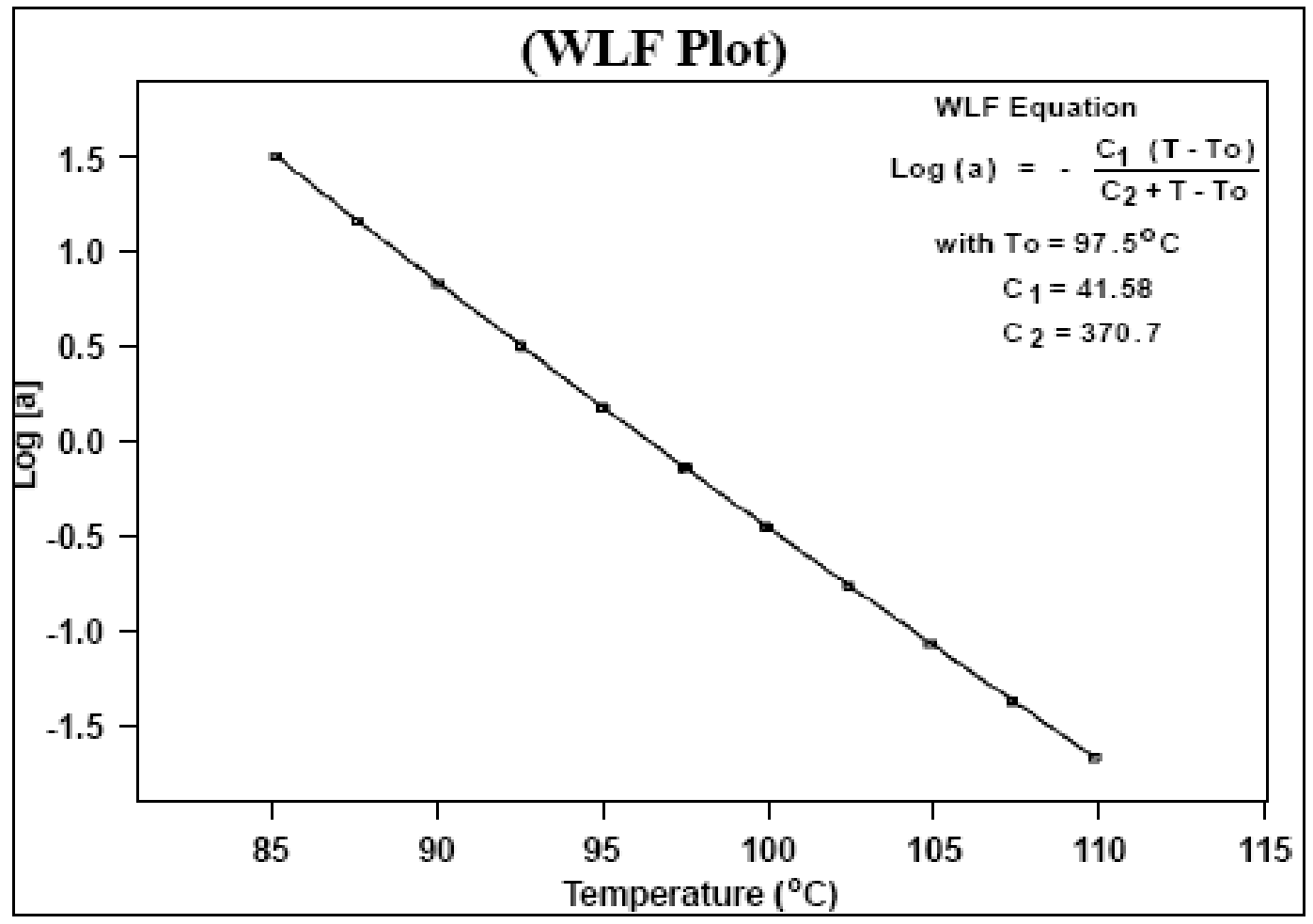

Figura 8.33 - Curva relativa a Equação de Williams-Landel-Ferry (WLF)

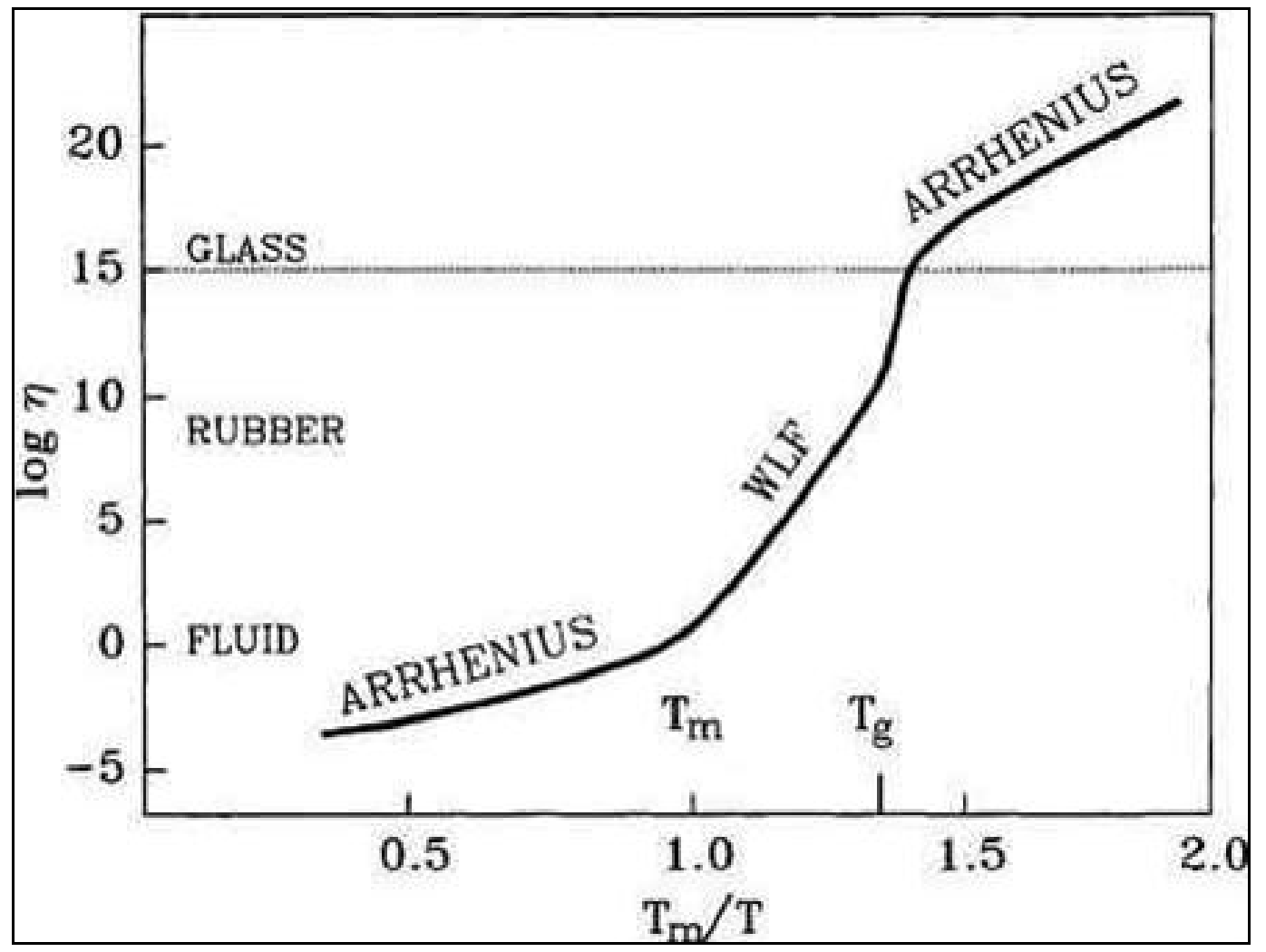

Figura 8.34 - Representa os intervalos onde valem as equações de Arrhenius e WLF 


\subsubsection{Ensaio de Propriedades Térmicas}

Os ensaios para caracterização das propriedades térmicas dos compósitos foram realizados no Laboratório de Propriedades Térmicas do Departamento de Engenharia de Materiais, Universidade Federal de São Carlos (DEMa-UFSCar) e foram seguidas as prescrições da norma DIN 51046, Parte II.

Foi utilizado o Método do Fio Quente Paralelo, que é um método direto, absoluto e não estacionário de determinação da condutividade térmica de um material. Este método foi utilizado pela primeira vez no Brasil por Santos apud Cimino e Badochi (2002), que introduziu um método de regressão não linear, determinando simultaneamente calor específico, condutividade térmica e difusividade térmica, considerando todos os pontos do transiente térmico.

O método, esquematizado na Figura 8.35, apresenta como fonte de calor um fio aquecido (Khantal A - resistividade 6,49 Ohms), elevando a sua temperatura devido à passagem de corrente elétrica por ele. A partir deste aquecimento há uma liberação de calor em quantidade constante, ao longo do tempo e por unidade de comprimento, que estabelece isotermas circulares no material.

Com um termopar (Cromel - Alumel) ligado a um registrador gráfico é possível medir a variação de temperatura obtida, determinando-se a condutividade térmica, a difusividade térmica e o calor específico do material. 


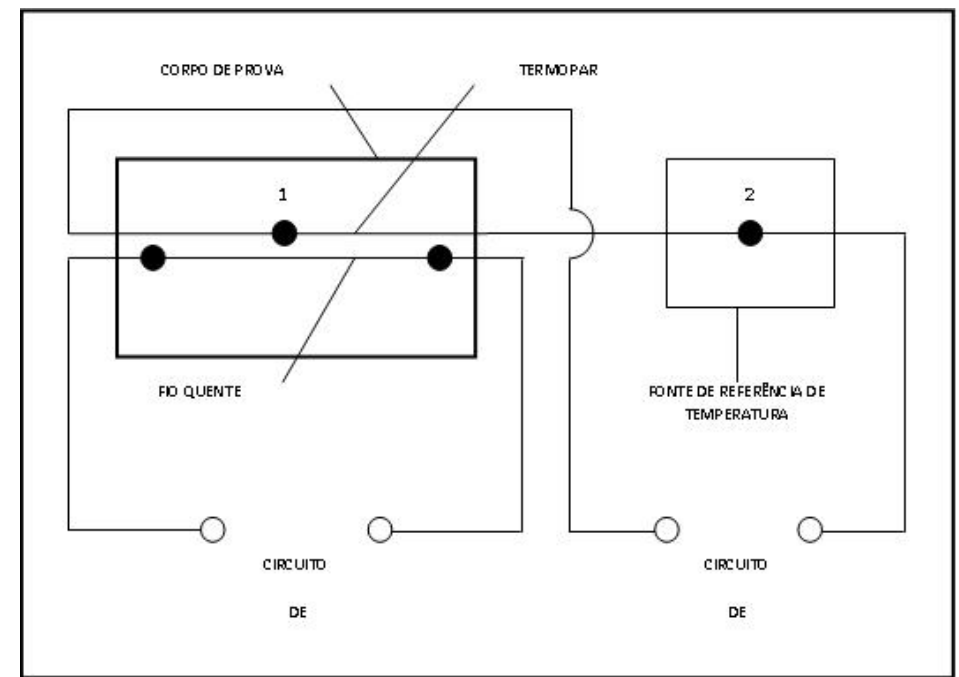

Figura 8.35 - Arranjo experimental com dispositivos utilizados no ensaio.

A Figura 8.36 apresenta o corpo de prova submetido ao ensaio, composto de duas partes, as quais devem ser colocadas sobrepostas, envolvendo os fios ligados aos dispositivos.

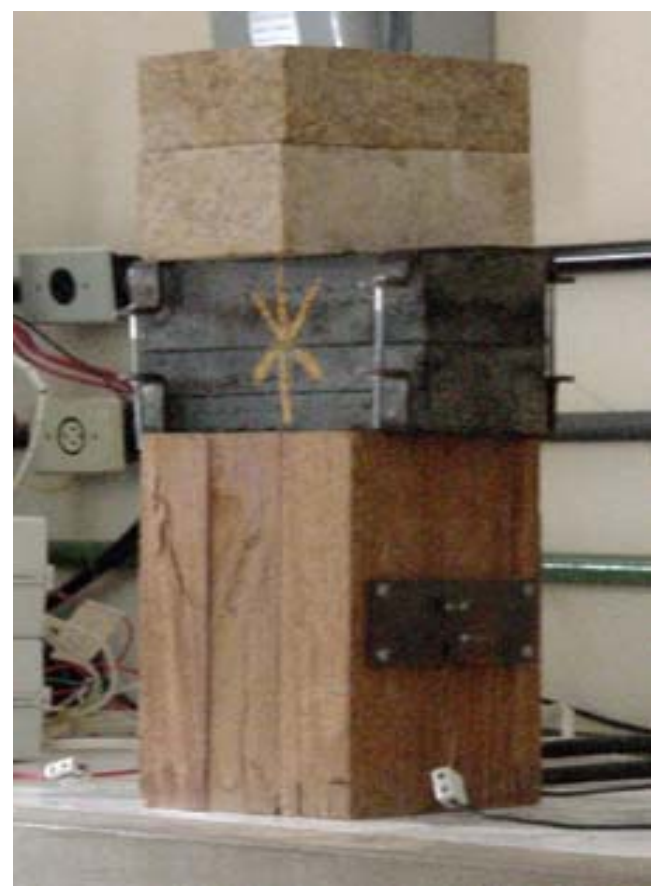

Figura 8.36 - Corpo de prova submetido ao ensaio. 


\section{CARACTERIZAÇÃO DOS MATERIAIS}

Neste capítulo estão apresentados os resultados e conclusões parciais dos ensaios efetuados para a caracterização dos materiais pesquisados neste trabalho.

\subsection{Resultados obtidos para a resina $\mathrm{PU}$}

\subsubsection{Ensaio de Determinação da Densidade}

A densidade da resina polimerizada foi determinada com base na ASTM D792 Density and Specific Gravity (Relative Density) of Plastics by Displacement.

\begin{tabular}{lc}
\hline Resina PU & Densidade" $9 "\left(\mathbf{g} / \mathrm{cm}^{\mathbf{3}}\right)$ \\
\hline $2: 1$ (poliol : prépolimero) & 1,05 \\
\hline
\end{tabular}

\subsubsection{Ensaio de Tração e intemperismo}

Este ensaio foi realizado com os corpos de prova mantidos no ambiente normal, em laboratório, e aqueles submetidos ao ensaio de resistência ao intemperismo. Foram considerados 5 corpos-de-prova de cada traço, dando origem aos gráficos das Figura 9.1 e 9.2. A partir deles, obteve-se os dados apresentados na Tabela 9.1. 
Neste ensaio avaliaram-se os seguintes corpos de prova:

- Corpos de prova com traço 2 (poliól) : 1 (pré-polímero), mantidos no laboratório, em ambiente normal.

- Corpos de prova com traço 2 (poliól) : 1 (pré-polímero), submetidos à câmara de intemperismo artificial durante 1000 horas, em ciclos de 4 horas de radiação UV e 4 horas de nebulização, alternadamente.

Os resultados obtidos são mostrados a seguir:

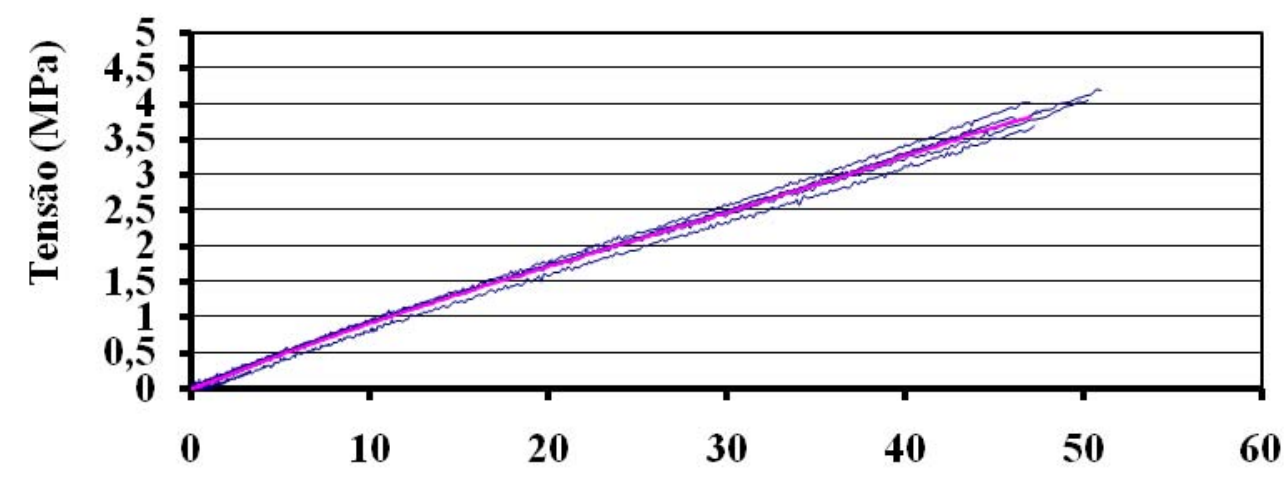

Deformação $(\%)$

Figura 9.1 - Tensão de ruptura e deformação das amostras mantidas em ambiente normal 


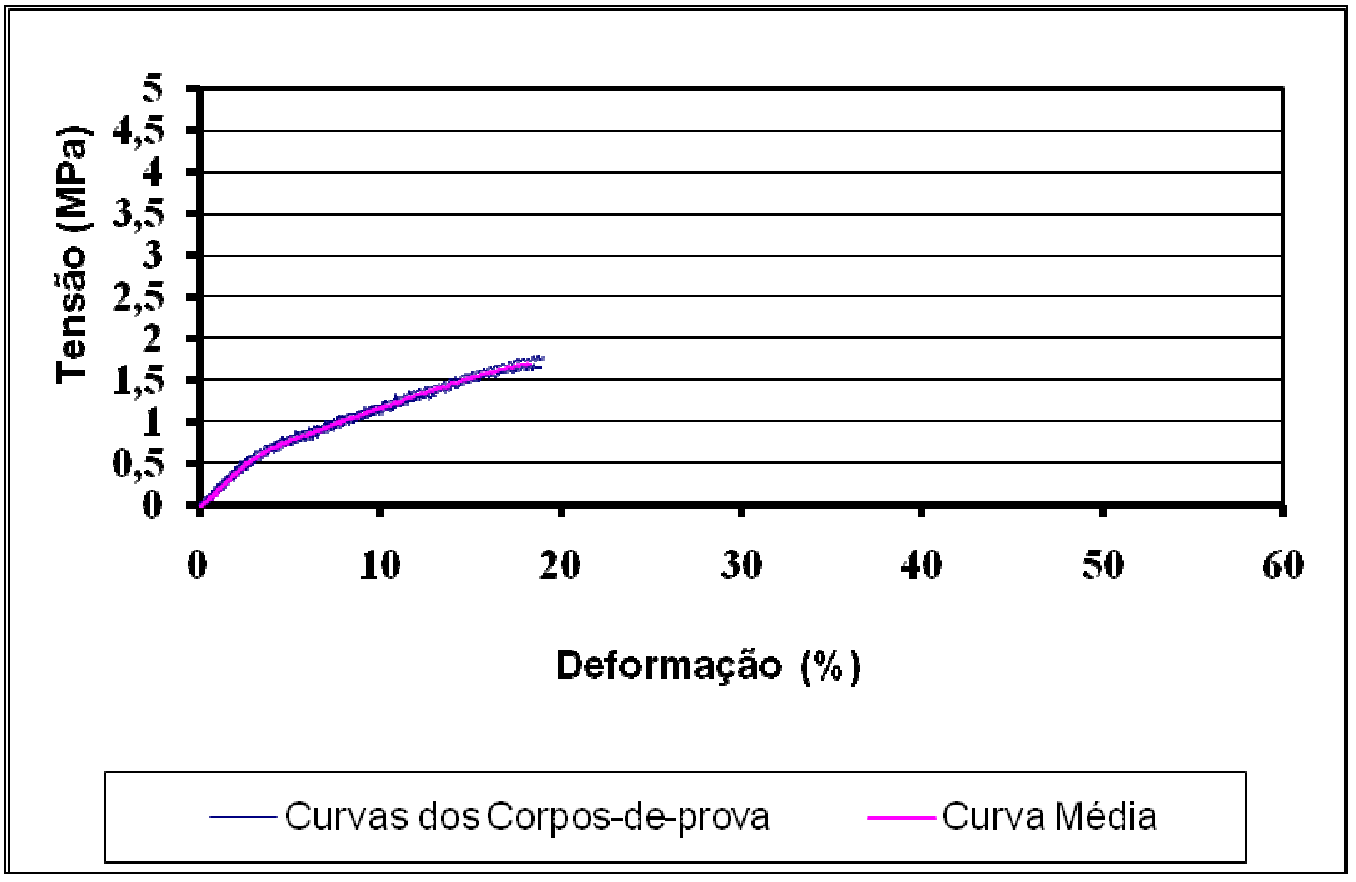

Figura 9.2 - Tensão de ruptura e deformação das amostras mantidas na câmara de intemperismo (radiação ultravioleta) por 1000 horas

Tabela 9.1 - Resultados do ensaio de resistência ao intemperismo artificial

\begin{tabular}{|c|c|c|c|c|}
\hline \multicolumn{4}{|c|}{ Tração } & \multirow{2}{*}{$\begin{array}{lr}\text { Módulo de } \\
\text { Elasticidade (MPa) }\end{array}$} \\
\hline Amostras & & Tensão (MPa) & Deformação (\%) & \\
\hline \multicolumn{5}{|l|}{ Resina PU } \\
\hline \multirow[t]{6}{*}{ 2:1 } & & 3,98 & 49,5 & 9,64 \\
\hline & & 3,97 & 49,5 & 9,63 \\
\hline & & 3,99 & 49,4 & 9,65 \\
\hline & Média & 3,98 & 49,47 & 9,64 \\
\hline & Desvio padrão & 0,01 & $\overline{0,06}$ & 0,01 \\
\hline & $\mathrm{CV}$ & 0,0025 & 0,0012 & 0,0010 \\
\hline
\end{tabular}

Pode-se observar das figuras 9.1 e 9.2 um decréscimo significativo, superior a 50\%, na capacidade de alongamento à tração nos corpos de prova submetidos à câmara de intemperismo, sem que ocorresse aparente perda de resistência à tração, revelando que a radiação UV acarretou alteração da reologia do polímero. 


\subsubsection{Ensaio de Compressão}

Este ensaio foi realizado submetendo-se 5 corpos de provas com traço 2(poliól) : 1 (pré-polímero), em massa, no ambiente normal em laboratório.

Os resultados obtidos são mostrados na Tabela 9.2 e Figura 9.3.

Tabela 9.2 - Resultados do ensaio compressão

\begin{tabular}{cllll}
\hline \multirow{2}{*}{$\begin{array}{c}\text { Compressão } \\
\text { Restras }\end{array}$} & Tensão (MPa) & Deformação (\%) & $\begin{array}{l}\text { Módulo } \\
\text { Elasticidade (MPa) }\end{array}$ \\
\hline $\mathbf{2 : 1}$ & & & \\
& & 14,18 & 69,14 & 1,21 \\
& 14,15 & 69,1 & 1,19 \\
& 14,20 & 69,16 & 1,23 \\
\hline & Média & 14,18 & 69,13 & 1,21 \\
\hline & Desvio padrão & 0,03 & 0,03 & 0,02 \\
\hline
\end{tabular}

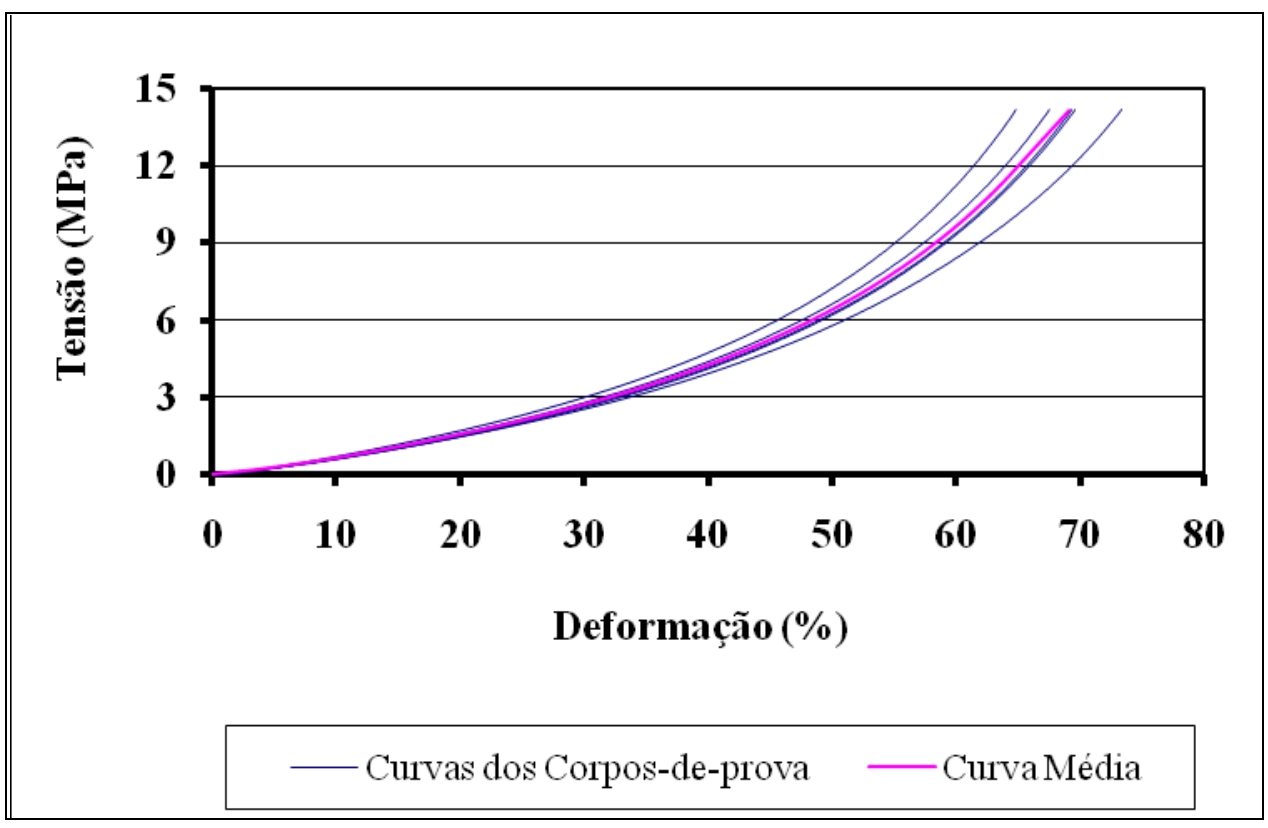

Figura 9.3 - Tensão de ruptura e deformação dos corpos de prova 
Os corpos de prova submetidos ao ensaio de compressão não foram mantidos na câmara de intemperismo em razão de sua conformação prismática impedir uma exposição homogênea de sua superfície aos raios UV.

\subsubsection{Ensaio de Dureza}

O valor obtido encontra-se próximo daqueles apresentados por plásticos de engenharia, utilizados na construção civil, sejam eles a base de poliuretano mineral, polipropileno, teflon, etc.

Na Tabela 9.3 estão os valores médios da dureza encontrados para corpos de prova mantidos no ambiente normal, em laboratório, e para outros submetidos à câmara de intemperismo.

Tabela 9.3 - Valores médios de dureza na escala Shore A

\begin{tabular}{ll}
\hline Amostra: & Dureza na Escala Shore "A" \\
2 (poliól) : 1 (pré-polímero) & \\
\hline Ambiente normal & 71 \\
\hline Intemperismo artificial & 74 \\
\hline
\end{tabular}

Os corpos de prova que ficaram expostos a radiação UV tiveram aumento da dureza, semelhante ao ocorrido com os corpos de prova submetidos ao ensaio de tração, os quais perderam parte de sua capacidade de alongamento.

\subsubsection{Ensaio de Abrasão}

As amostras apresentaram desgastes menor que $1 \%$ para 500 ciclos e $1 \mathrm{Kg}$ de carga. 


\subsection{Resultados obtidos com o compósito resina PU e borracha}

A seguir estão os resultados encontrados para os diferentes compósitos, a partir da melhor composição granulométrica obtida para as partículas de borracha, a proporção de mistura com a resina PU, e de desempenho satisfatório com vistas à utilização deste material em estudo na construção civil.

\subsubsection{Distribuição granulométrica}

A Tabela 9.4 apresenta as porcentagens retidas em cada peneira, após a mistura destas frações granulométricas, em quantidades iguais, conforme são comercializadas pela usina de Cravinhos - SP.

Tabela 9.4 - Graduação das partículas segundo seus diâmetros comerciais

\begin{tabular}{lcccccc}
\hline & \multicolumn{6}{c}{ Granulometria (\%) retida acumulada nas peneiras } \\
\cline { 2 - 6 } $\begin{array}{l}\text { Tamanhos comerciais das } \\
\text { partículas de borracha } \\
\text { (medidas em mm) }\end{array}$ & $\mathbf{4 , 8}$ & $\mathbf{2 , 4}$ & $\mathbf{1 , 2}$ & $\mathbf{0 , 6}$ & $\mathbf{0 , 3}$ & $\mathbf{0 , 1 5}$ \\
\hline & 0,0 & 57,5 & 98,9 & 99,7 & 99,8 & 99,9 \\
P05 & 0,0 & 0,0 & 68,3 & 99,4 & 99,6 & 99,9 \\
P10 & 0,0 & 0,0 & 2,7 & 59,4 & 87,4 & 97,6 \\
P20 & 0,0 & 0,0 & 0,0 & 1,7 & 54,6 & 90,6 \\
P30 & & & & & &
\end{tabular}

As curvas de distribuição granulométrica da mistura das partículas de borracha, segundo as dimensões anteriormente citadas, foram consideradas dentro dos limites 
estabelecidos na NBR $7211^{8}$, em relação à zona 3 e zona 4. As Figuras 9.4 e 9.5 apresentam as curvas segundo os respectivos limites.

Isto foi feito visando se ter um ponto de partida para uma análise da compacidade mais adequada para o compósito em estudo. Na Tabela 9.5 e Figuras 9.4 e 9.5 estão constados, respectivamente, os valores percentuais dos limites granulométricos estabelecidos em norma, e as curvas representativas da distribuição granulométrica decorrente da mistura das diferentes graduações comerciais das partículas de borracha fornecidas pela usina.

Tabela 9.5 - Porcentagens retidas nas peneiras da serie normal, das amostras misturadas em quantidades iguais

\begin{tabular}{cccccc}
\hline Peneira & \multirow{2}{*}{ \# P30 } & \# P20 & \# P10 & \# P5 & $\begin{array}{c}\text { Mistura das } \\
\text { Amostras } \\
\text { P5, P10, P20 } \\
\text { e P30 }\end{array}$ \\
\hline \# (mm) & \% Retida & \% Retida & \% Retida & \% Retida & $\begin{array}{c}\text { \% Retida } \\
9,5\end{array}$ \\
6,3 & 0 & 0 & 0 & 0 & 0 \\
4,8 & 0 & 0 & 0 & 0 & 0 \\
2,4 & 0 & 0 & 0 & 0 & 0 \\
1,2 & 0 & 0 & 20 & 34 & 14 \\
0,6 & 0 & 82 & 75 & 63 & 35 \\
0,3 & 65 & 16 & 5 & 3 & 23 \\
0,15 & 30 & 2 & 0 & 0 & 20 \\
\hline Fundo & 5 & 0 & 0 & 0 & 8 \\
\hline Soma & $\mathbf{1 0 0}$ & $\mathbf{1 0 0}$ & $\mathbf{1 0 0}$ & 100 & $\mathbf{1 0 0}$ \\
\hline
\end{tabular}

\footnotetext{
${ }^{8}$ A nova norma NBR/NM 7211 teve seus limites granulométricos alterados, porém se manteve a distribuição anterior, para a análise segundo o Método de Ruthfuchs.
} 


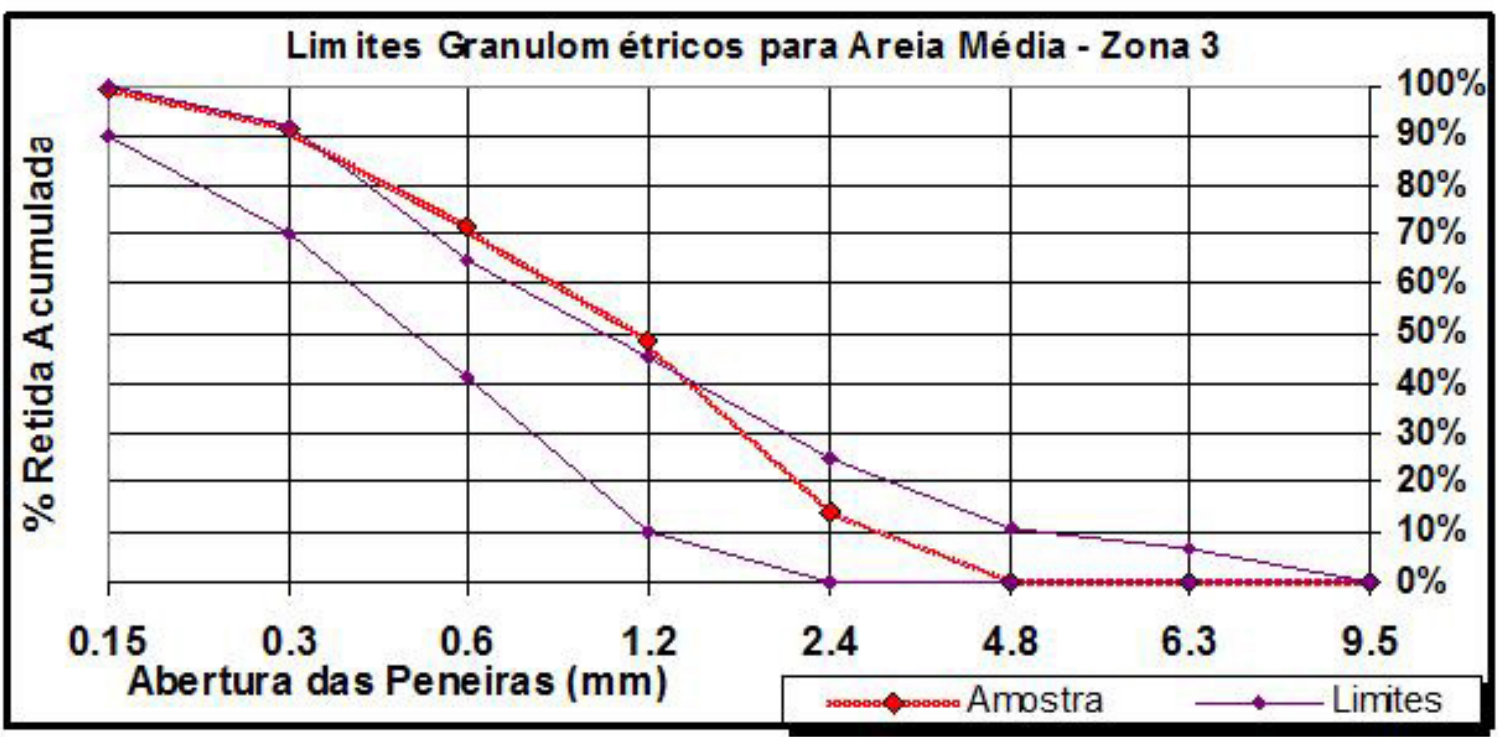

Figura 9.4 - Curva da mistura das quatro granulometrias, segundo a zona 3

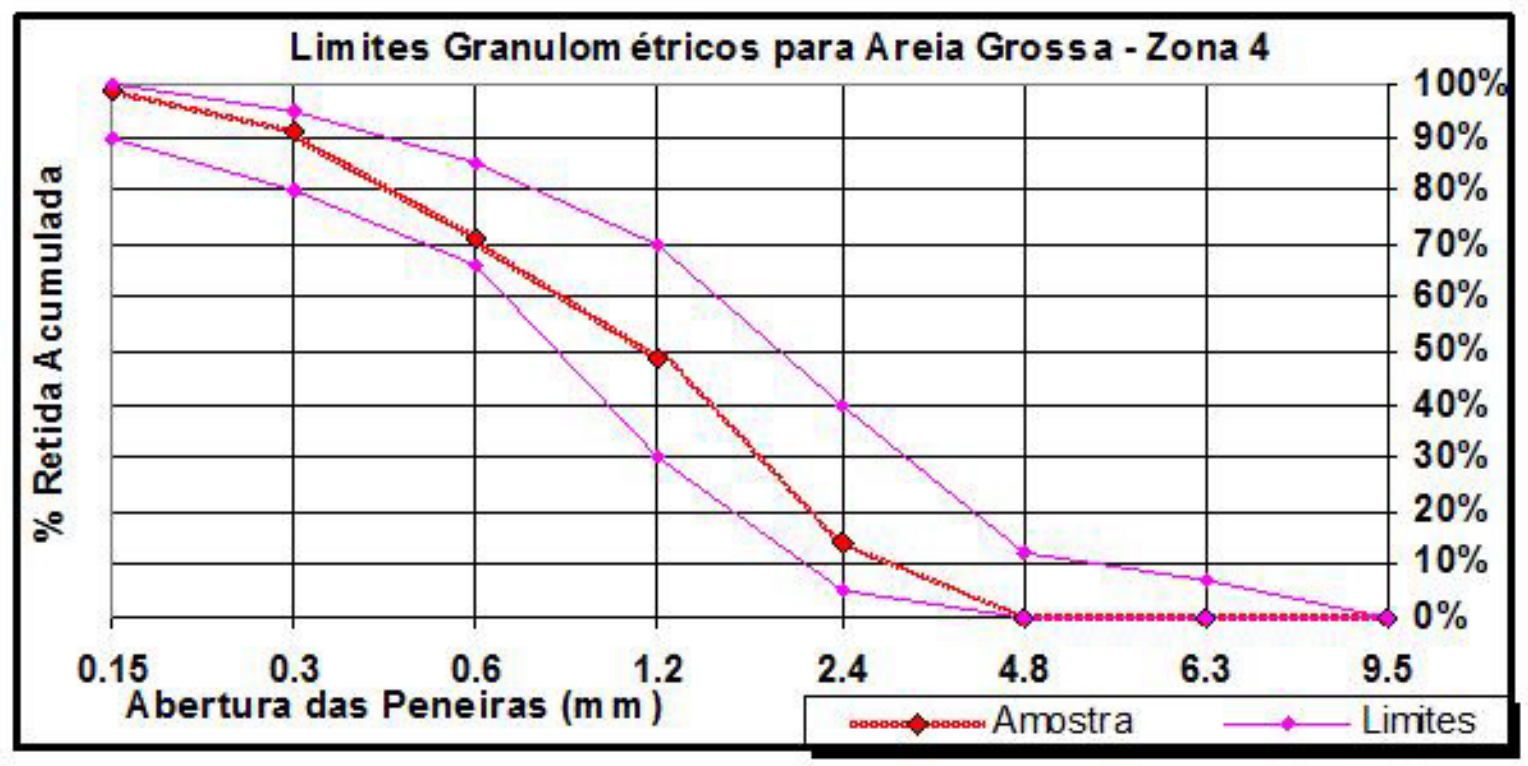

Figura 9.5 - Curva representativa da mistura das quatro granulometrias, segundo a zona 4

A partir da curva média, nas zonas 3 e 4, foi determinada a composição granulométrica de maior compacidade, empregando-se para isso o Método de Ruthfuchs ${ }^{9}$ adotado na área de engenharia de solos e pavimentação, e que se mostrou adequado para a determinação da composição granulométrica das partículas de borracha. Foram consideradas,

\footnotetext{
${ }^{9}$ SENÇO, W. Manual de técnicas de pavimentação. 2. ed. São Paulo: Pini, 2008. v. 1. p. 282.
} 
a partir desse método, duas composições granulométricas, caracterizadas como Zona 3 e Zona 4.

As Figuras 9.6 e 9.7 apresentam os valores obtidos pelo Método de Ruthfuchs, a partir do qual foram determinados os porcentuais mais adequados das partículas de borracha visando à constituição do compósito. Este método permitiu encontrar a distribuição granulométrica com a maior compacidade nas composições consideradas, o que otimizou a quantidade de resina PU como aglomerante, contribuindo para diminuir o custo do compósito.

Na Figura 9.6 consta-se o gráfico para a determinação dos porcentuais de cada graduação comercial para a curva média da zona 3, e na Figura 9.7 apresenta-se igualmente para a curva média da zona 4.

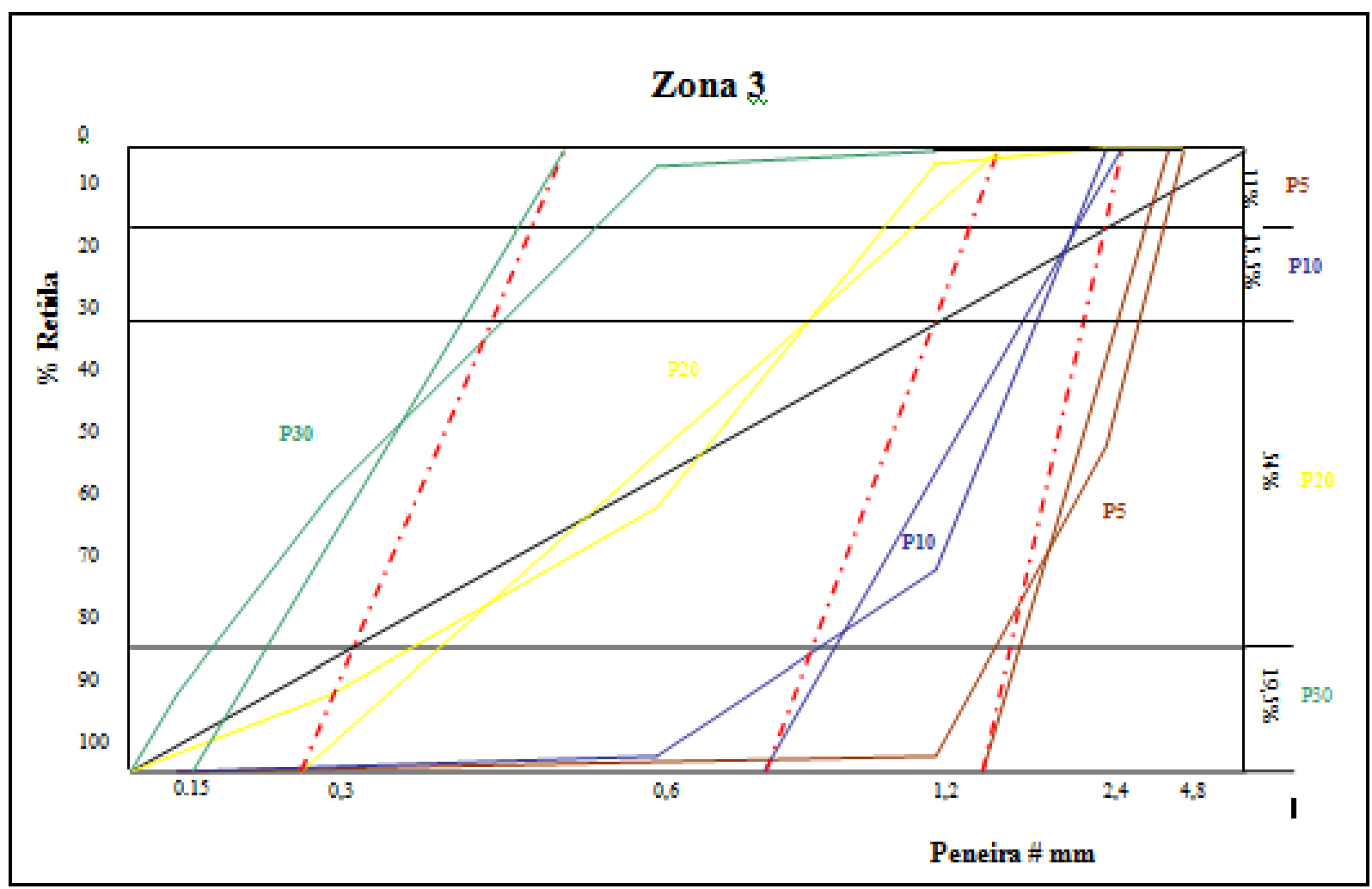

Figura 9.6 - Curvas para determinação das frações das amostras segundo a curva média da zona 3 


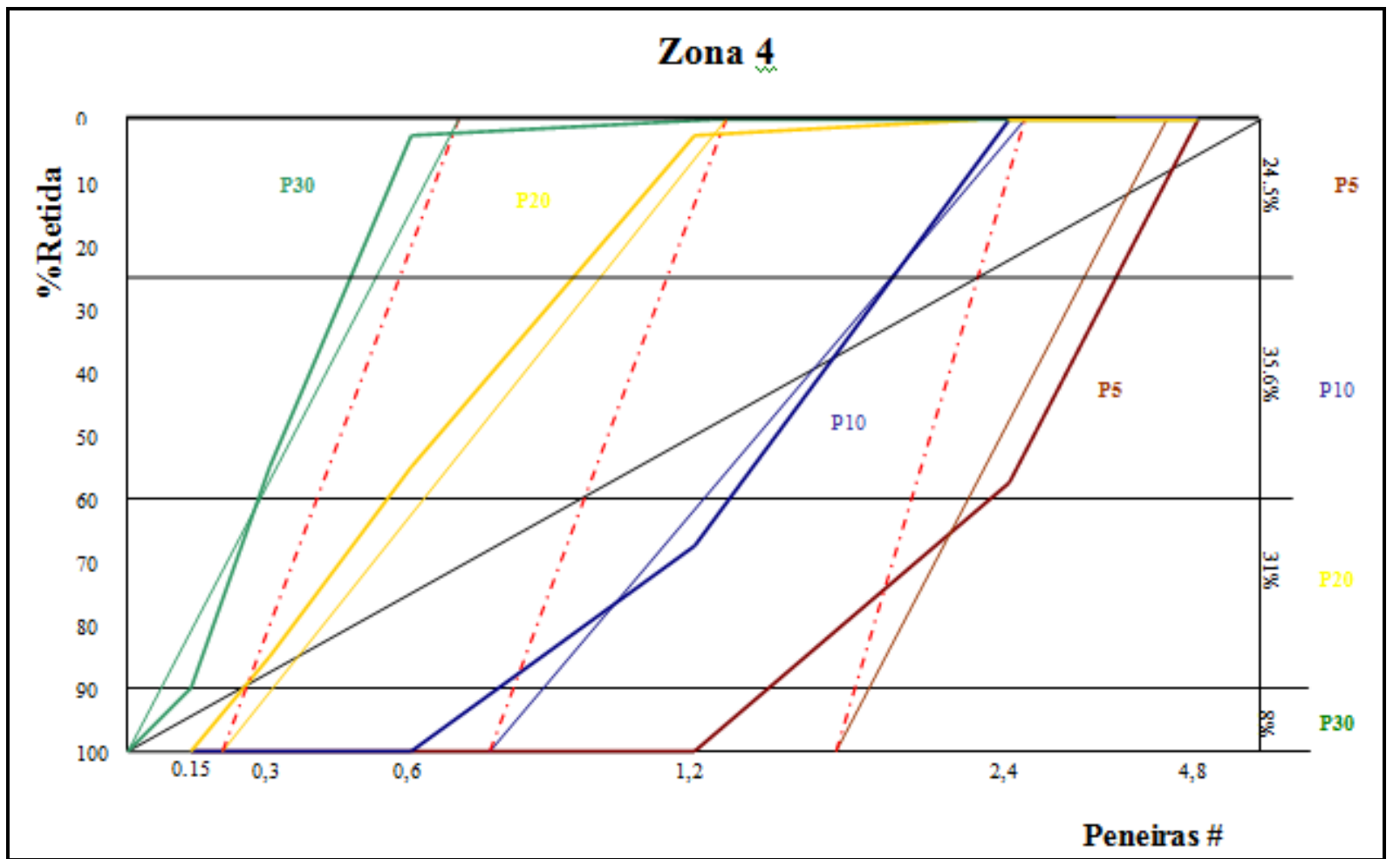

Figura 9.7 - Curvas para determinação das frações das amostras segundo a curva média da zona 4

\subsubsection{Microscopia eletrônica de varredura (MEV)}

Para o ensaio de microscopia eletrônica de varredura (MEV) as amostras dos compósitos, após a prensagem e polimerização da resina poliuretanica sob ação facultativa de calor, foram crio-fraturadas em nitrogênio líquido, técnica adotável no caso de materiais multifásicos.

Este procedimento tornou possível uma melhor detecção da morfologia interna dos compósitos segundo as distintas proporções borracha x polímero, podendo-se perceber claramente seus detalhes estruturais nas regiões de interface entre partículas de borracha e a resina poliuretana usada como aglomerante.

O imbricamento entre as partículas de borracha de diferentes tamanhos possibilita a melhor compacidade, a qual pode ser avaliada pela análise das micrografias constantes das figuras a seguir. (elétrons secundários). 


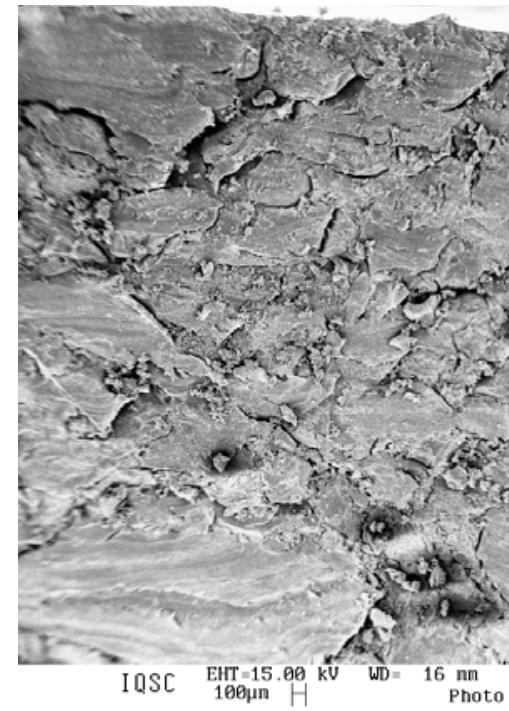

ZONA 3 15\%, sem poliol, com forma fria, $\rho=1,16(58 \mathrm{x})$

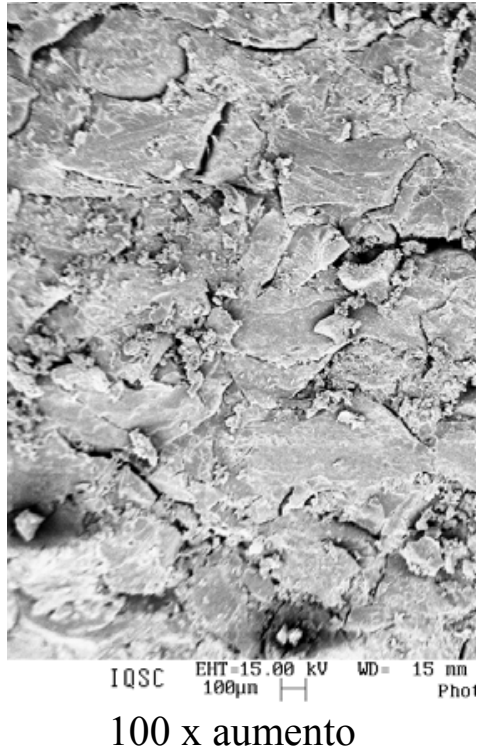

$100 \mathrm{x}$ aumento

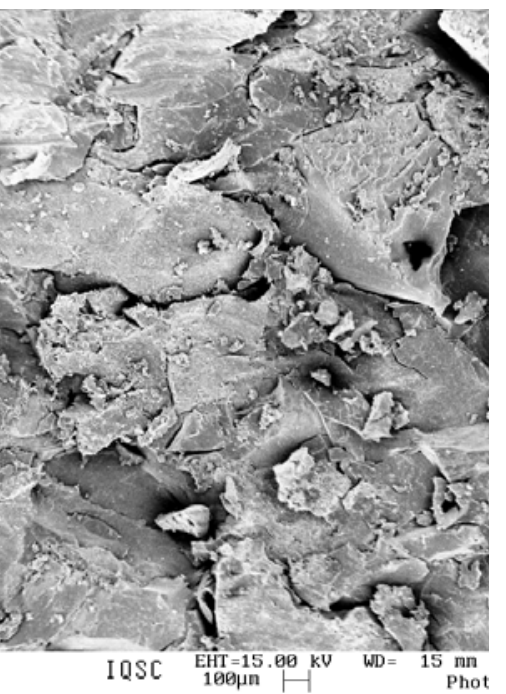

$100 \mathrm{x}$ aumento
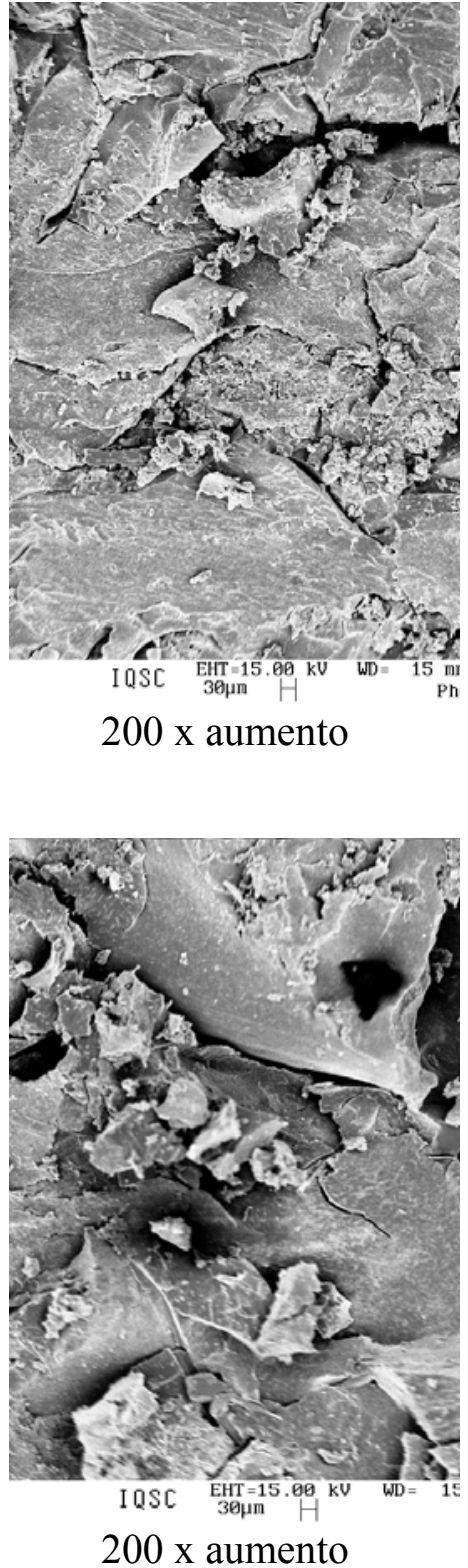

Zona 3 15\%, sem poliol, fôrma fria $\rho=1,06(59 x)$

Figura 9.8 - Imagens em diferentes ampliações da seção fraturada do compósito, com 15\% de resina, moldado a frio e densidades de $1,16 \mathrm{~g} / \mathrm{cm} 3$ e de $1,06 \mathrm{~g} / \mathrm{cm}^{3}$

Durante a etapa inicial do trabalho foram promovidos estudos visando à determinação dos procedimentos mais satisfatórios para a produção do compósito, incluindo a distribuição granulométrica das partículas de borracha, o teor de resina mais adequado para a consolidação do compósito, e ainda outras condições relativamente à temperatura (normal ou com aquecimento) para a investigação do andamento da polimerização. 
Além destes parâmetros acima também foi investigada a interferência que uma prévia umectação das partículas de borracha, somente com aplicação de poliol, poderia trazer ao compósito.

A Figura 9.8 apresenta o compósito de granulometria na Zona 3, teor de resina de $15 \%$ em relação à borracha e a moldagem feita com a fôrma na temperatura ambiente.

A diferença entre ambas consiste na densidade do compósito $\left(1,06 \mathrm{~g} / \mathrm{cm}^{3}\right.$ e 1,16 $\mathrm{g} / \mathrm{cm}^{3}$ ), determinada em função da quantidade de material colocado nos insertos do molde cilíndrico e também da força aplicada para a compactação.

Os resultados obtidos nos corpos de prova de densidade de $1,16 \mathrm{~g} / \mathrm{cm}^{3}$ foram melhores, como se pode observar da Figura 9.8, pois se mostram com presença de menor número de vazios, com as partículas imbricadas (os espaços intergranulares maiores preenchidos com partículas menores).

Na Figura 9.9 estão os compósitos moldados com a fôrma aquecida (à quente, como se referiu), e também se pode verificar que o de densidade mais alta $\left(1,16 \mathrm{~g} / \mathrm{cm}^{3}\right)$ se apresenta com menor número de vazios internos, e com uma sensível melhoria de sua compacidade.

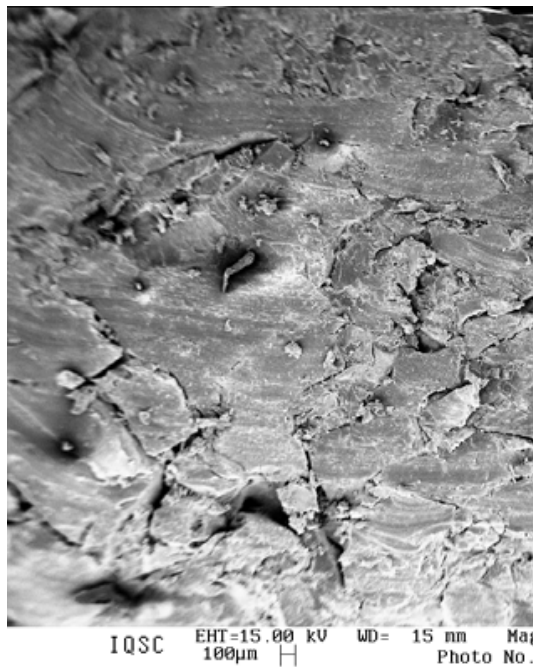

Zona 3 15\% com poliol fôrma à quente $\rho=1,06(60 x)$

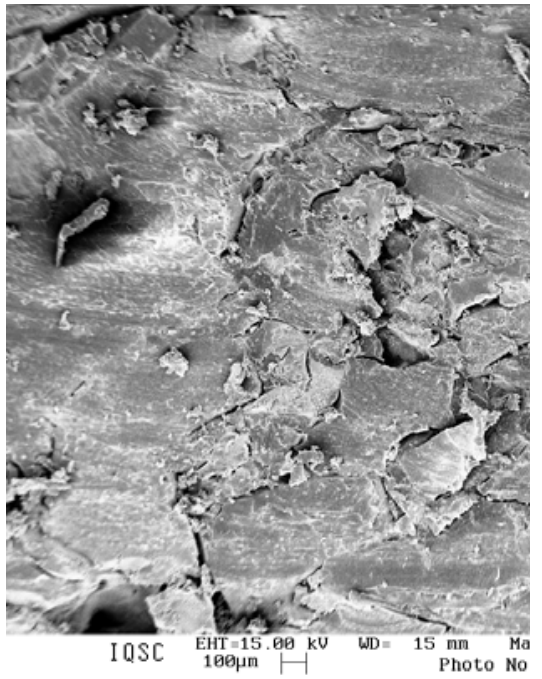

$100 \mathrm{x}$ aumento

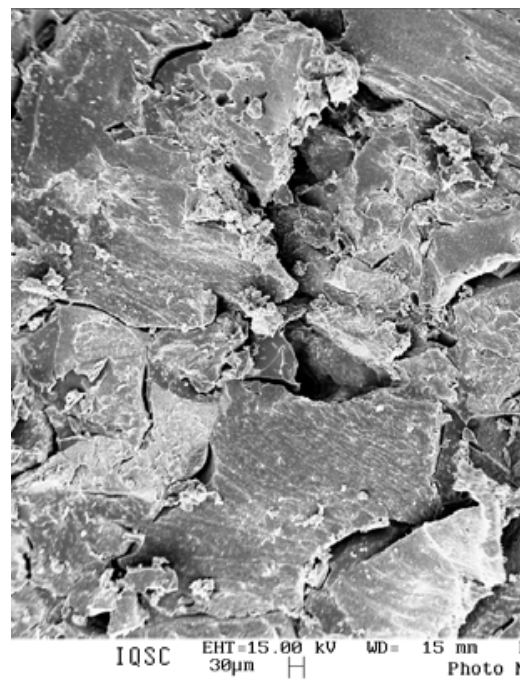

$200 \times$ aumento 


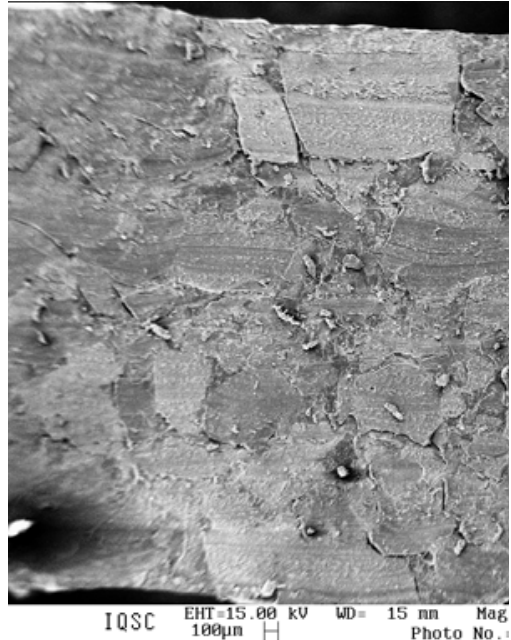

Zona 3 15\% com poliol forma à quente $\rho=1,16(60 \mathrm{x})$

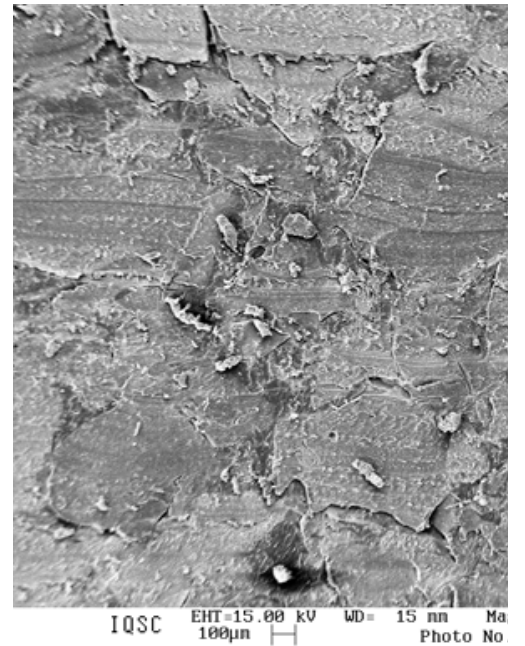

$100 \mathrm{x}$ aumento

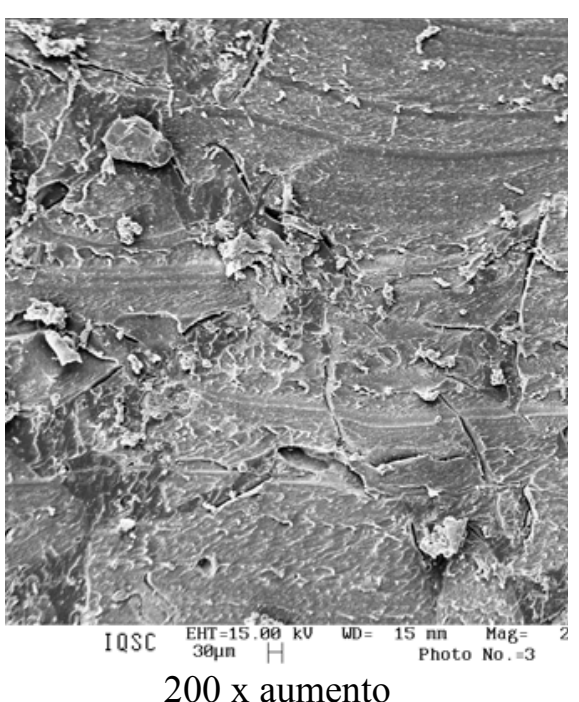

$200 \mathrm{x}$ aumento

Figura 9.9 - Imagens em diferentes ampliações da seção fraturada do compósito, com 15\% de resina, moldado à quente e densidades de $1,06 \mathrm{~g} / \mathrm{cm} 3$ e de $1,16 \mathrm{~g} / \mathrm{cm}^{3}$

A Figura 9.10 apresenta as imagens do compósito contendo 15\% de resina e densidade de $1,16 \mathrm{~g} / \mathrm{cm} 3$, quando se fez variar apenas a temperatura da fôrma durante a moldagem. A aplicação do calor $\left(60^{\circ} \mathrm{C}\right.$ a $\left.70^{\circ} \mathrm{C}\right)$ possibilita um aumento da velocidade de polimerização, o que é satisfatório quando se visa um processo industrial de produção e se faz necessária a liberação dos moldes no menor tempo possível.

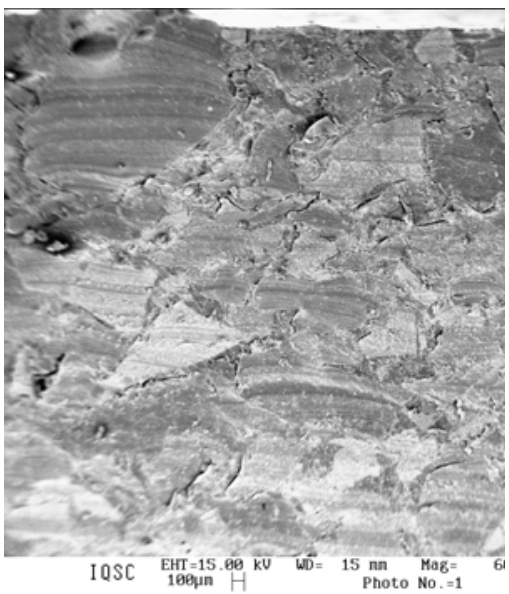

Zona 3 15\% com poliol forma fria $\rho=1,16(60 x)$

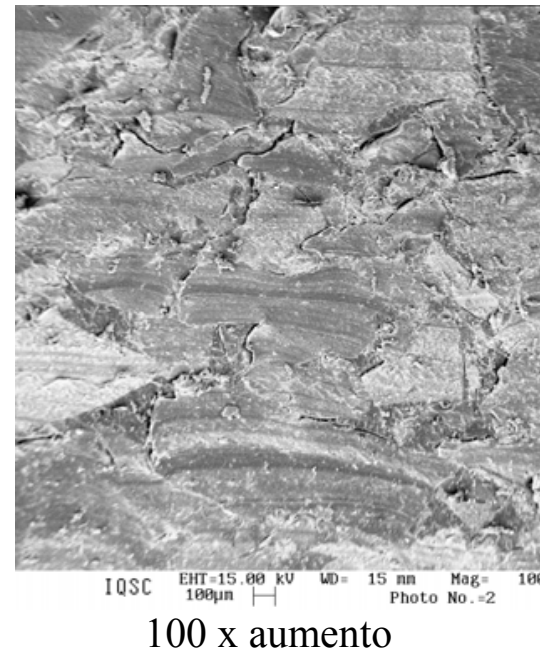

$100 \mathrm{x}$ aumento

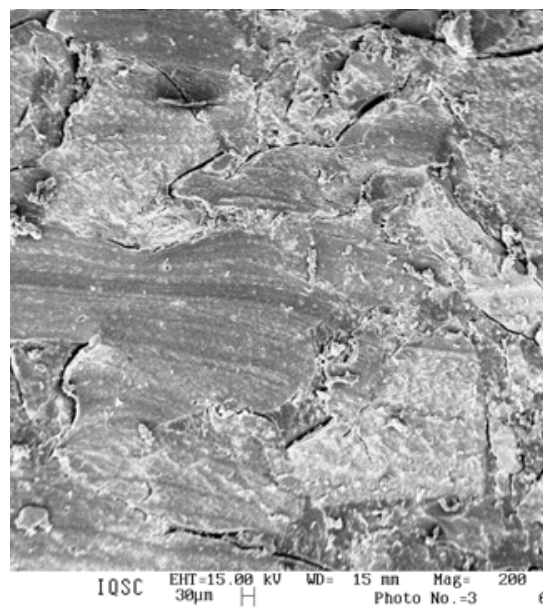

$200 \times$ aumento 


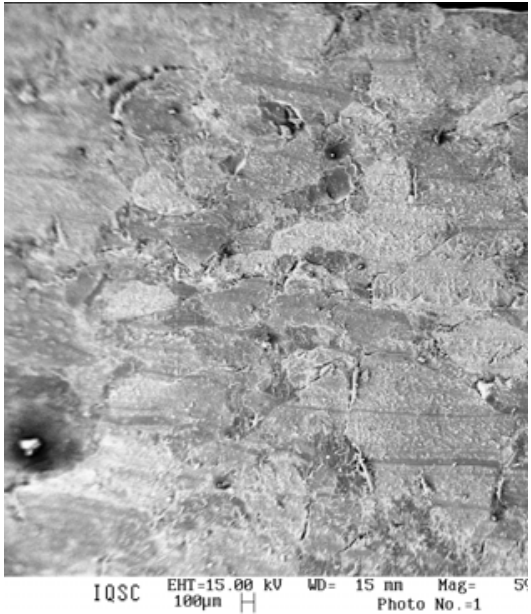

Zona 3 15\% com poliol

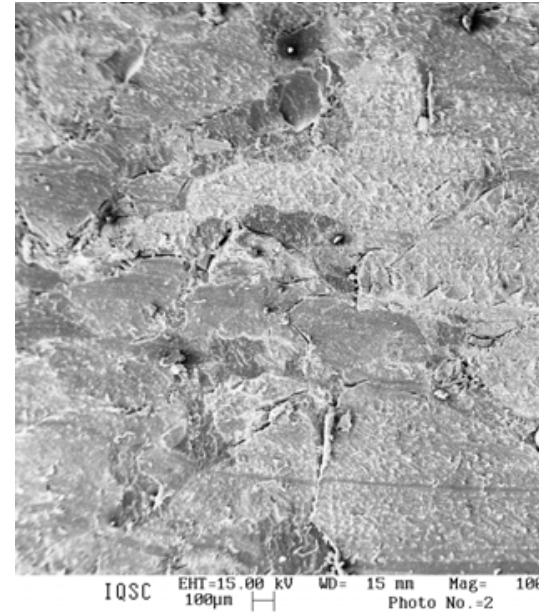

100x aumento

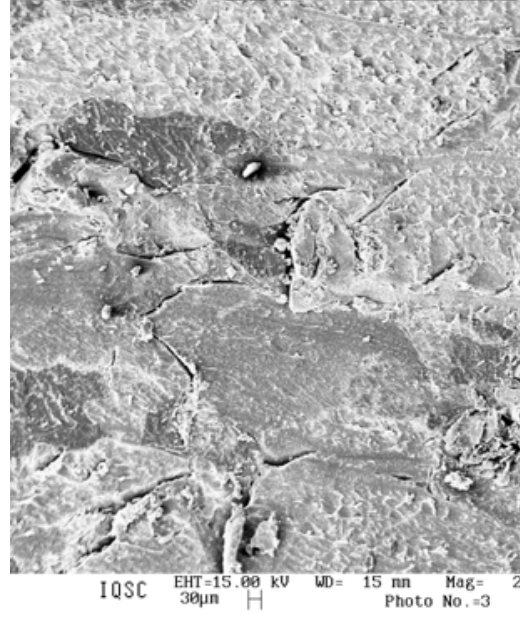

200x aumento forma quente $\rho=1,16(59 x)$

Figura 9.10 - Imagens em diferentes ampliações da seção fraturada do compósito, com 15\% de resina, moldado à quente e a frio, de mesma densidade $1,16 \mathrm{~g} / \mathrm{cm}^{3}$

As imagens constantes da Figura 9.10 constituem-se em uma das razões pelas quais se adotou a moldagem à quente, em fôrma aquecida, e a partir desses resultados iniciais foi possível o estabelecimento de um melhor juízo sobre os procedimentos a serem adotados no decorrer da pesquisa.

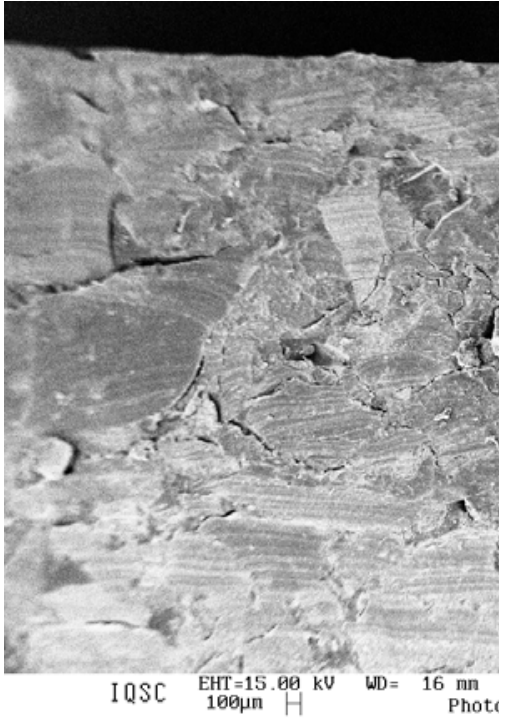

Zona 3 20\% sem poliol forma quente $\rho=1,16(57 x)$

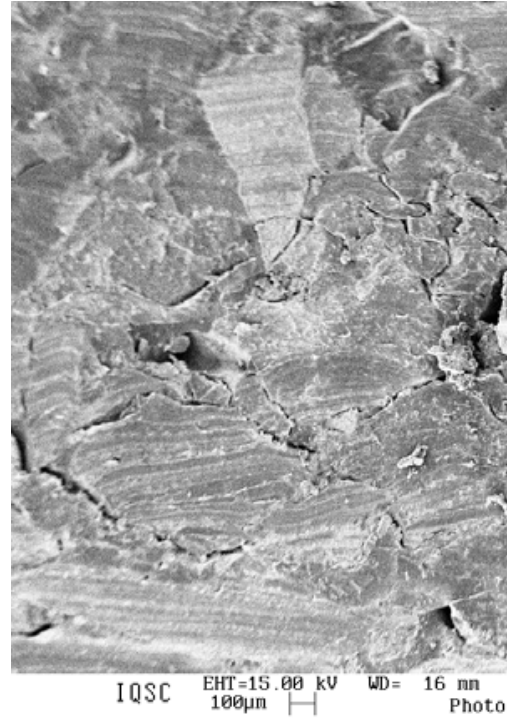

$100 \mathrm{x}$ aumento

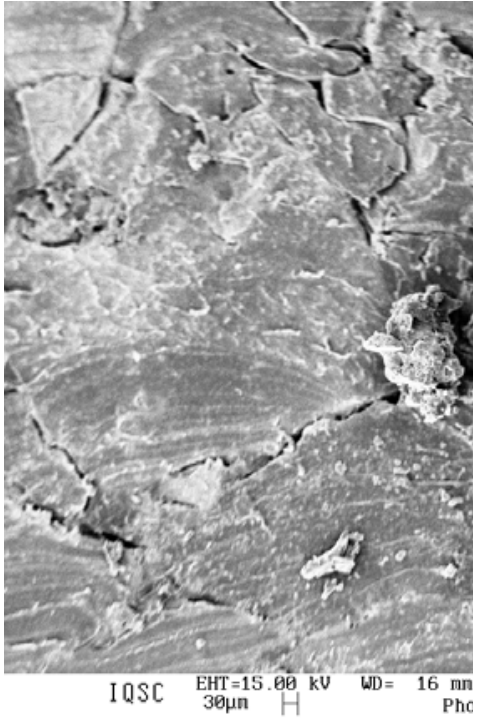

$200 \mathrm{x}$ aumento 


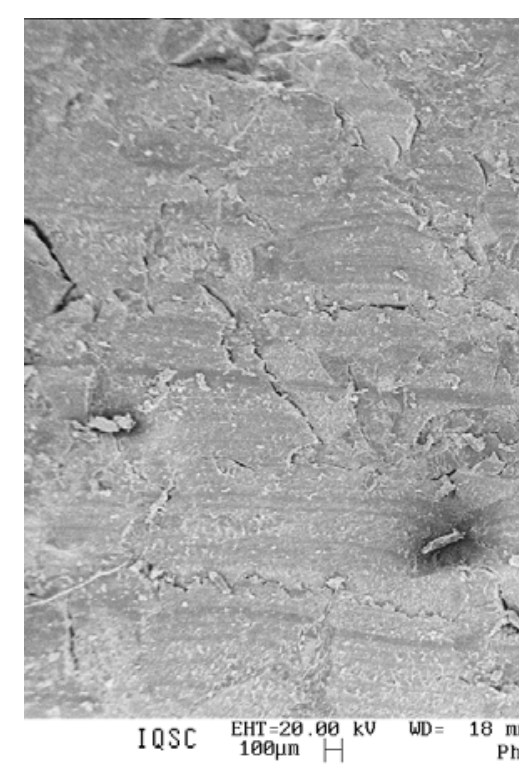

Zona 3 18\% sem poliol forma quente $\rho=1,16(62 x)$

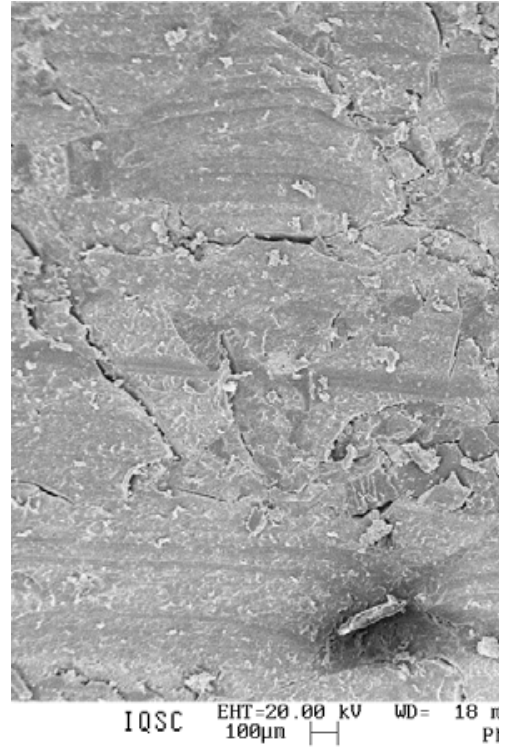

$100 \times$ aumento

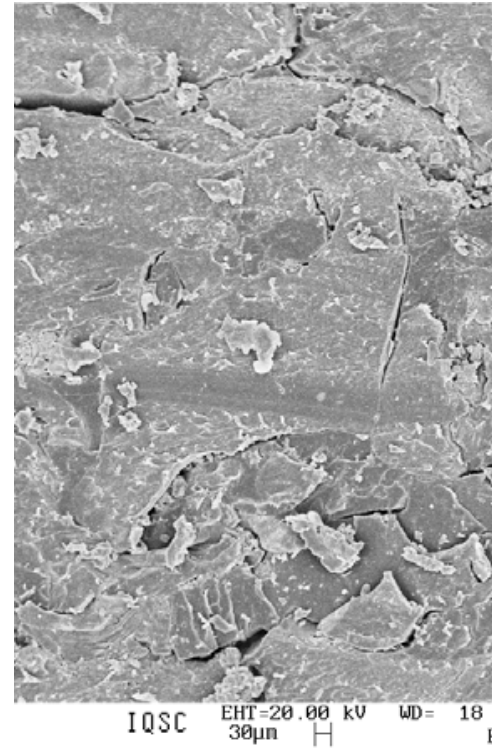

$200 \mathrm{x}$ aumento

Figura 9.11 - Imagens em diferentes ampliações da seção fraturada do compósito, com $20 \%$ e $18 \%$ de resina, moldado à quente, e de mesma densidade $1,16 \mathrm{~g} / \mathrm{cm}^{3}$

A Figura 9.11 apresenta as imagens do compósito contendo $18 \%$ e $20 \%$ de resina e densidade de $1,16 \mathrm{~g} / \mathrm{cm}^{3}$, e sem prévia umectação com o poliol.

Este ensaio permitiu comparar as diversas possibilidades de processamento do compósito variando a temperatura de polimerização e porcentagem de resina, mostrando a morfologia das amostras com os conteúdos de 12\%, 15\%, 18\% e 20\% de resina PU em relação às partículas de borracha.

O compósito com $18 \%$ de resina apresentou resultados mais satisfatórios conforme pode ser visto nas micrografias. Durante a etapa de moldagem dos corpos de prova foi verificado que este teor de resina é o mais satisfatório dentre os demais. 


\subsubsection{Ensaios Mecânicos dos Compósitos}

O ensaio de MEV permitiu a análise da microestrutura interna do compósito (ligação resina/borracha) e a definição das proporções resina/borracha para execução dos ensaios mecânicos realizados em seguida.

Para realização dos ensaios de compressão e de tração foram desenvolvidos moldes e dispositivos para a produção de corpos de prova, de maneira a se obter as características mais adequadas do compósito quando da determinação de suas propriedades mecânicas.

Para a avaliação da resistência à compressão foi desenvolvida uma fôrma cilíndrica contendo vários insertos, de modo a que determinada quantidade do material foi colocado em seu interior, suficiente para possibilitar a densidade de $1,16 \mathrm{~g} / \mathrm{cm}^{3}$, e em seguida compactado segundo uma pressão variando de 10 a $12 \mathrm{MPa}$, concomitante ao aumento de temperatura do molde.

\subsubsection{Ensaio de compressão dos compósitos}

Os corpos de prova puderam ter sua densidade variando em função da quantidade de material (borracha + resina) previamente lançada no interior de cada inserto existente no interior da fôrma, mas que foi mantida fixa em $1,16 \mathrm{~g} / \mathrm{cm}^{3}$.

$\mathrm{Na}$ Tabela 9.6 estão dispostos os valores médios dos corpos de prova que foram moldados na primeira etapa do trabalho, com teores de resina de $12 \%$ e $15 \%$, e a granulometria na zona 3 e zona 4, com o intuito de verificar as condições destes diferentes compósitos. 
Tabela 9.6 - Valores da resistência à compressão com teores de $12 \%$ e $15 \%$ de resina, com a granulometria da borracha segundo a zona 4

\begin{tabular}{|c|c|c|c|c|c|}
\hline \multicolumn{3}{|c|}{ Compressão } & \multicolumn{3}{|c|}{ Compressão } \\
\hline Z4 12\% PU & $\begin{array}{l}\text { Tensão } \\
(\mathrm{MPa})\end{array}$ & $\begin{array}{c}\text { Deformação } \\
(\%)\end{array}$ & Z4 15\% PU & $\begin{array}{l}\text { Tensão } \\
(\mathrm{MPa})\end{array}$ & $\begin{array}{c}\text { Deformação } \\
(\%)\end{array}$ \\
\hline 1 & 8 & 47 & 1 & 9 & 51 \\
\hline 2 & 7,5 & 43 & 2 & 9 & 51 \\
\hline 3 & 7,5 & 43 & 3 & 9,2 & 52 \\
\hline 4 & 7,4 & 43 & 4 & 9,1 & 53 \\
\hline 5 & 7,2 & 47 & 5 & 4,3 & 43 \\
\hline 6 & 7,1 & 47 & Média & 8,12 & 50 \\
\hline 7 & 6,3 & 45 & $\begin{array}{l}\text { Desvio } \\
\text { Padrão }\end{array}$ & 2,13705 & 4 \\
\hline 8 & 7,5 & 47 & C.V. & 0,26318 & 0,08 \\
\hline 9 & 7,5 & 47 & & & \\
\hline 10 & 8,4 & 47 & & & \\
\hline Média & 7,36 & 46,6 & & & \\
\hline $\begin{array}{l}\text { Desvio } \\
\text { Padrão }\end{array}$ & 0,55015 & $\mathbf{1 , 8 9 7 3 7}$ & & & \\
\hline C.V. & 0,07475 & 0,04072 & & & \\
\hline
\end{tabular}

Na Tabela 9.7 estão os valores estatísticos referentes ao compósito em duas diferentes composições granulométricas, Zona 3 e Zona 4, com teores de resina PU variando de $12 \%$ e $15 \%$. 
Tabela 9.7 - Valores estatísticos das resistências à compressão dos compósitos

\begin{tabular}{lccccc}
\hline Tensão (MPa) & $\begin{array}{c}\text { Teste } \\
\text { Estatístico }\end{array}$ & p-valor & $\begin{array}{c}\text { Deformação } \\
(\%)\end{array}$ & $\begin{array}{c}\text { Teste } \\
\text { Estatístico }\end{array}$ & p-valor \\
\hline \multirow{2}{*}{ z4-12\% e z4-15\% } & ANOVA & $0,6799(\mathrm{NS})$ & $\mathrm{z} 4-12 \%$ e $15 \%$ & ANOVA & $0,0113(\mathrm{~S})$ \\
& t de Student & $0,2612(\mathrm{NS})$ & & $\mathrm{t}$ de Student & $0,0335(\mathrm{~S})$ \\
$\mathrm{z} 3-12 \%$ e z4-12\% & ANOVA & $0,0004(\mathrm{~S})$ & $\mathrm{z} 3-12 \%$ e z4-12\% & ANOVA & $0,0874(\mathrm{NS})$ \\
& t de Student & $4,87 \mathrm{E}-8(\mathrm{~S})$ & & $\mathrm{t}$ de Student & $0,0428(\mathrm{~S})$ \\
$\mathrm{z} 3-15 \%$ e z4-15\% & ANOVA & $0,0016(\mathrm{~S})$ & $\mathrm{z} 3-12 \%$ e z4-12\% & ANOVA & $0,0008(\mathrm{~S})$ \\
& t de Student & $0,0218(\mathrm{~S})$ & & t de Student & $0,0143(\mathrm{~S})$ \\
\hline
\end{tabular}

$\mathrm{Na}$ avaliação analítica a hipótese de nulidade, que postula não haver diferença entre as dosagens, foi testada em todos os casos com nível de significância de 0,05. Para a Análise de Variância, ANOVA - técnica estatística que subdivide a variabilidade total de um conjunto de dados em seus componentes e estabelece se as médias de vários grupos são estatisticamente diferentes, entre as distintas dosagens, obteve-se diferença significativa entre as médias com p-valor (valor associado a uma estatística de teste que indica a probabilidade de um valor tão ou mais extremo que o observado, ocorrer apenas por acaso em varias repetições do experimento).

Na comparação da tensão, medida em MPa, as amostras da zona 4 com12\% e $15 \%$ de PU, os resultados obtidos foram de 0,6799 na ANOVA e de 0,2612 para o teste $t$ de Student, as diferenças não apresentaram significância. Na comparação da Deformação, medida em \%, as amostras da zona 4 com $12 \%$ e $15 \%$ de PU, os resultados obtidos foram de 0,0113 na ANOVA e de 0,0335 para o teste $t$ de Student, ambas significativas.

$\mathrm{Na}$ comparação da tensão, medida em $\mathrm{MPa}$, as amostras da zona 3 com $12 \%$ e zona 4 com $12 \%$ de PU, os resultados obtidos foram de 0,0004 na ANOVA e de $2,87 \times 10^{-8}$ para o teste $\mathrm{t}$ de Student, as diferenças foram significativas. Na comparação da Deformação, medida em porcentagem (\%), as amostras da zona 3 com $12 \%$ e zona 4 com $12 \%$ de PU, os resultados 
obtidos foram de 0,0874 na ANOVA que não apresentou significância, e de 0,0428 para o teste t de Student, que é significativa.

Na comparação da tensão, medida em MPa, as amostras da zona 3 com15\% e zona 4 com $15 \%$ de PU, os resultados obtidos foram de 0,0016 na ANOVA e de 0,0218 para o teste $\mathrm{t}$ de Student, e as diferenças tiveram significância. Na comparação da Deformação, medida em $\%$, as amostras da zona 3 com $15 \%$ e zona 4 com $15 \%$ de PU, os resultados obtidos foram de 0,0008 na ANOVA e de 0,0143 para o teste t de Student, ambas significativas.

O teste de compressão e tração da zona 3 e 4 foi realizado variando a porcentagem de resina PU (12\% e 15\%). No decorrer do ensaio notou-se que os corpos de prova da zona 3 comportaram-se mais adequadamente, e foi verificado também que os coeficientes de variação apresentaram menor dispersão.

Na Tabela 9.8 apresenta-se os resultados obtidos com compósitos enquadráveis na zona 3, que foi considerada de melhor homogeneidade, com a qual se variou os teores de resina PU em relação à borracha, de $12 \%, 15 \%, 18 \%$ e $20 \%$. 
Tabela 9.8 - Resistência à compressão dos compósitos com granulometria na zona3 e as porcentagens de resina PU utilizadas

\begin{tabular}{|c|c|c|c|c|c|c|c|c|}
\hline & Compres & io Z3 12\% & Compre & o Z3 15\% & Compres & o Z3 18\% & Compre & $10 \mathrm{Z3} \mathrm{20 \%}$ \\
\hline & $\begin{array}{l}\text { Tensão } \\
\text { (MPa) }\end{array}$ & $\begin{array}{l}\text { Deforma } \\
\text { ção }(\%)\end{array}$ & $\begin{array}{l}\text { Tensão } \\
\text { (MPa) }\end{array}$ & $\begin{array}{l}\text { Deforma } \\
\text { ção }(\%)\end{array}$ & $\begin{array}{l}\text { Tensão } \\
\text { (MPa) }\end{array}$ & $\begin{array}{l}\text { Deforma } \\
\text { ção }(\%)\end{array}$ & $\begin{array}{l}\text { Tensão } \\
(\mathrm{MPa})\end{array}$ & $\begin{array}{l}\text { Deforma } \\
\text { ção (\%) }\end{array}$ \\
\hline & 5,8000 & 4,70000 & 5,3000 & 43,0000 & 10,7800 & 58,0000 & 9,1300 & 54,0000 \\
\hline & 5,7000 & 4,70000 & 5,5000 & 43,0000 & 10,7200 & 57,0000 & 9,8800 & 55,0000 \\
\hline & 5,7000 & 4,70000 & 5,4000 & 43,0000 & 10,8900 & 59,0000 & 11,5400 & 58,0000 \\
\hline & 5,4000 & 4,70000 & 5,4000 & 43,0000 & 10,8300 & 59,0000 & 7,7600 & 52,0000 \\
\hline & 5,3000 & 4,70000 & 5,3000 & 45,0000 & 10,7600 & 59,0000 & 11,2700 & 58,0000 \\
\hline & 5,0000 & 4,70000 & 5,3000 & 45,0000 & 10,6800 & 56,0000 & 5,0800 & 45,0000 \\
\hline & 4,8000 & 4,60000 & 5,2000 & 45,0000 & 10,9100 & 59,0000 & 10,0600 & 56,0000 \\
\hline & 4,8000 & 4,60000 & 5,2000 & 45,0000 & 10,8900 & 59,0000 & & \\
\hline & 5,7000 & 4,70000 & 5,5000 & 45,0000 & 10,9200 & 59,0000 & & \\
\hline & & & & & 10,8600 & 57,0000 & & \\
\hline Média & 5,3556 & 46,7778 & 5,3444 & 44,1111 & 10,8200 & 58,3333 & 9,2457 & 54,0000 \\
\hline Desvio & 0,4035 & 0,4410 & 0,1130 & 1,0541 & 0,0886 & 1,1180 & 2,2361 & 4,5092 \\
\hline Padrão & & & & & & & & \\
\hline C.V. & 0,0753 & 0,0094 & 0,0212 & 0,0239 & 0,0082 & 0,0192 & 0,2419 & 0,0835 \\
\hline
\end{tabular}

$\mathrm{Na}$ análise descritiva da compressão, tensão e deformação, observou-se que a dosagem de $18 \%$ apresentou as médias da tensão e da deformação superior às demais e os coeficientes de variação foram de menor variabilidade. Por esta razão considerou-se o teor de resina de 18\%, em relação à borracha como sendo o melhor para os compósitos analisados.

Na Tabela 9.9 estão os resultados da análise estatística com relação à tensão, medida em MPa, nas amostras da zona 3 com as dosagens de 12\%, 15\%, 18\% e $20 \%$ de PU. Os resultados obtidos foram de $6,46 \times 10^{-14}$ na ANOVA, evidenciando a diferença significativa entre as médias. A comparação da dosagem de 18\% (concentração que apresentou melhores 
resultados), com as demais dosagens por meio do teste $\mathrm{t}$ de Student, as diferenças foram significativas para as dosagens de $12 \%$ e $15 \%$.

Tabela 9.9 - Resultados da análise estatística de tensão na zona 3, com os diferentes teores de resina

\begin{tabular}{lcc}
\hline \multicolumn{1}{c}{ Tensão (MPa) } & Teste Estatístico & p-valor \\
\hline z3-18\%;12\%;15\%;20\% & ANOVA & 6,46 E-14 (S) \\
z3-18\% e 12\% & t de Student & 9,74 E-10 (S) \\
z3-18\% e 15\% & t de Student & 5,13 E-24 (S) \\
z3-18\% e 20\% & t de Student & $0,0556(\mathrm{NS})$ \\
\hline
\end{tabular}

Na Tabela 9.10 estão colocados os resultados da análise estatística quanto à deformação, medida em porcentagem, das amostras da zona 3 com as dosagens de $12 \%, 15 \%$, $18 \%$ e $20 \%$ de PU. Os resultados obtidos foram de 5,82×10-15 na ANOVA, evidenciando a diferença significativa entre as médias. A comparação da dosagem de $18 \%$ (concentração que apresentou melhores resultados), com as demais dosagens por meio do teste $\mathrm{t}$ de Student, mostra que as diferenças foram significativas para as todas as dosagens.

Tabela 9.10 - Resultados da análise estatística de deformação na zona 3, com os diferentes teores de resina

\begin{tabular}{lcc}
\hline \multicolumn{1}{c}{ Tensão (MPa) } & Teste Estatístico & p-valor \\
\hline z3-18\%;12\%;15\%;20\% & ANOVA & 5,82 E-15 (S) \\
z3-18\% e 12\% & t de Student & 7,35 E-13 (S) \\
z3-18\% e 15\% & t de Student & 5,62 E-16 (S) \\
z3-18\% e 20\% & t de Student & $0,0233(\mathrm{~S})$ \\
\hline
\end{tabular}

A Figura 9.12 apresenta as curvas obtidas para uma amostra de pneu agrícola, que foi submetida aos esforços de tração e compressão, com o objetivo de avaliar o comportamento da borracha tal qual se encontra nos pneus comercializados, comparando com os resultados conseguidos nos compósitos em estudo. 
No eixo y consta a carga em Newtons e no eixo x o deslocamento em $\mathrm{cm}$. Fazendo-se a transformação das unidades para tensão x deformação específica, a tensão de ruptura da borracha de pneu de trator $^{10}$ ficou com valor médio de $8 \mathrm{MPa}$ e o módulo de elasticidade de 4 MPa, com um alongamento de $200 \%$.
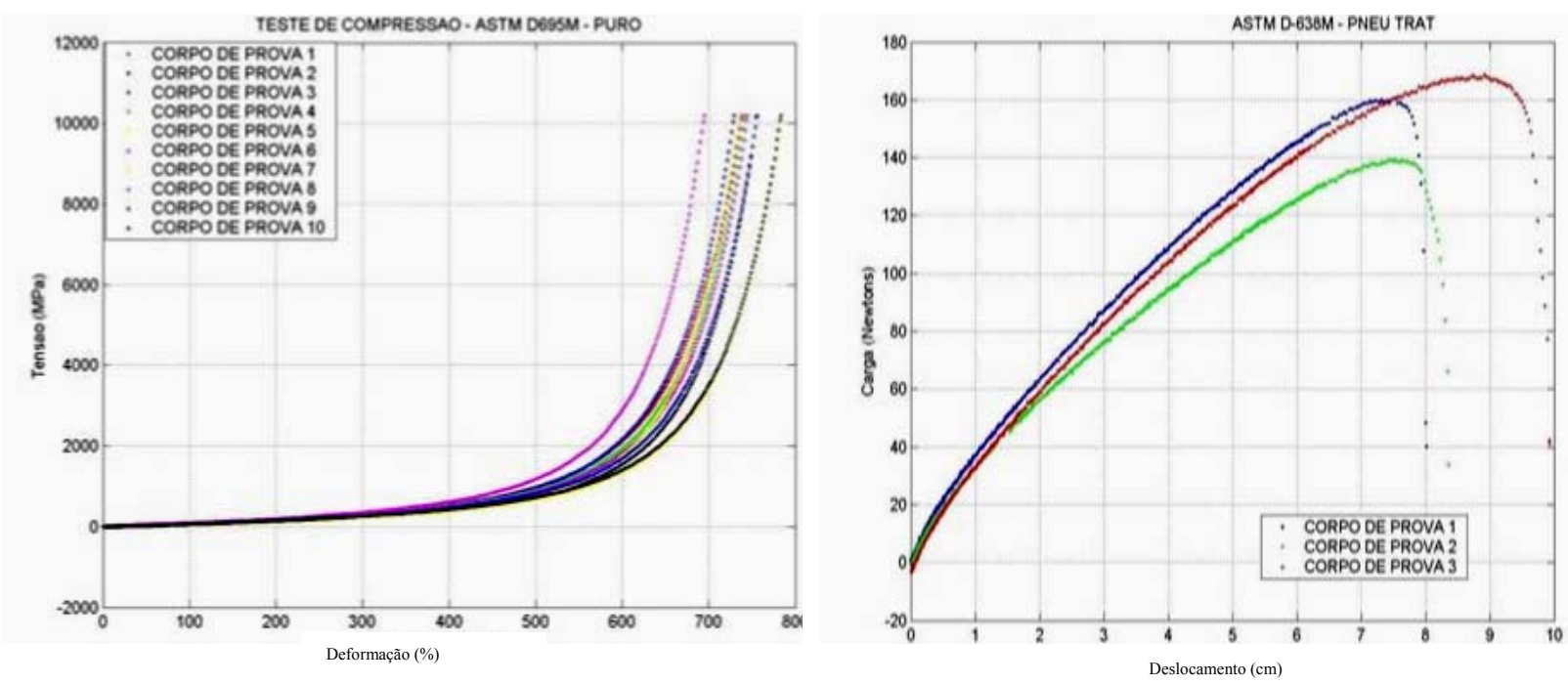

Figura 9.12 - Curvas representativas dos resultados dos ensaios de compressao e tração em amostra de pneu agrícola

\footnotetext{
${ }^{10}$ Foi considerada uma amostra de pneu agrícola para servir de referência aos compósitos em estudo. Isto se justifica em razão do pneu agrícola ter grande quantidade de borracha que pode ser removida da banda de rodagem.
} 


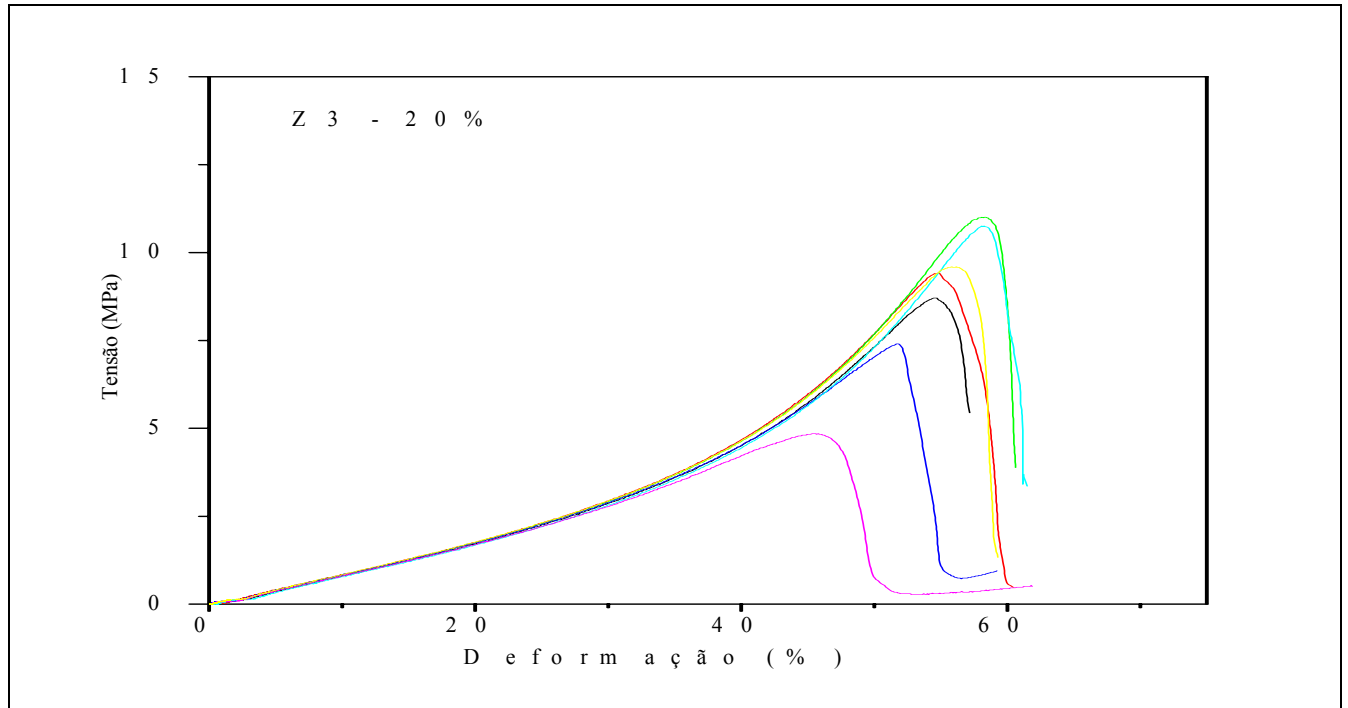

Figura 9.13 - Curva representativa do resultado do ensaio de compressão em compósito com teor de resina de $20 \%$

As Figuras 9.13 e 9.14 apresentam as resistências à compressão dos corpos de prova com $20 \%$ e $18 \%$ de teor de resina.

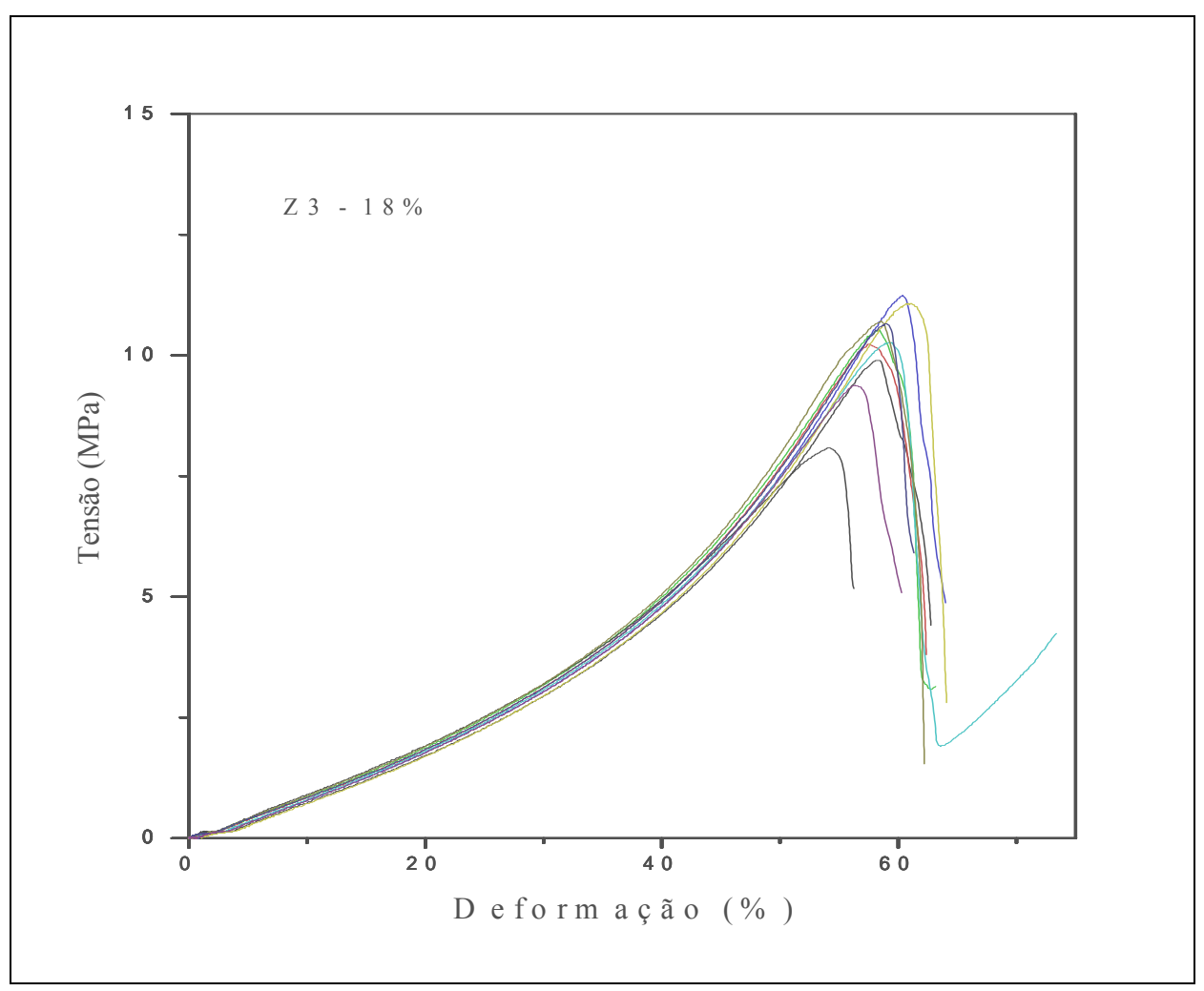

Figura 9.14 - Curva representativa do resultado do ensaio de compressão em compósito com teor de resina de $18 \%$ 
$\mathrm{Na}$ Figura 9.15 estão representadas as curvas obtidas para o compósito com composição granulométrica na zona 3 e teor de resina de $15 \%$ em relação ao conteúdo de borracha.

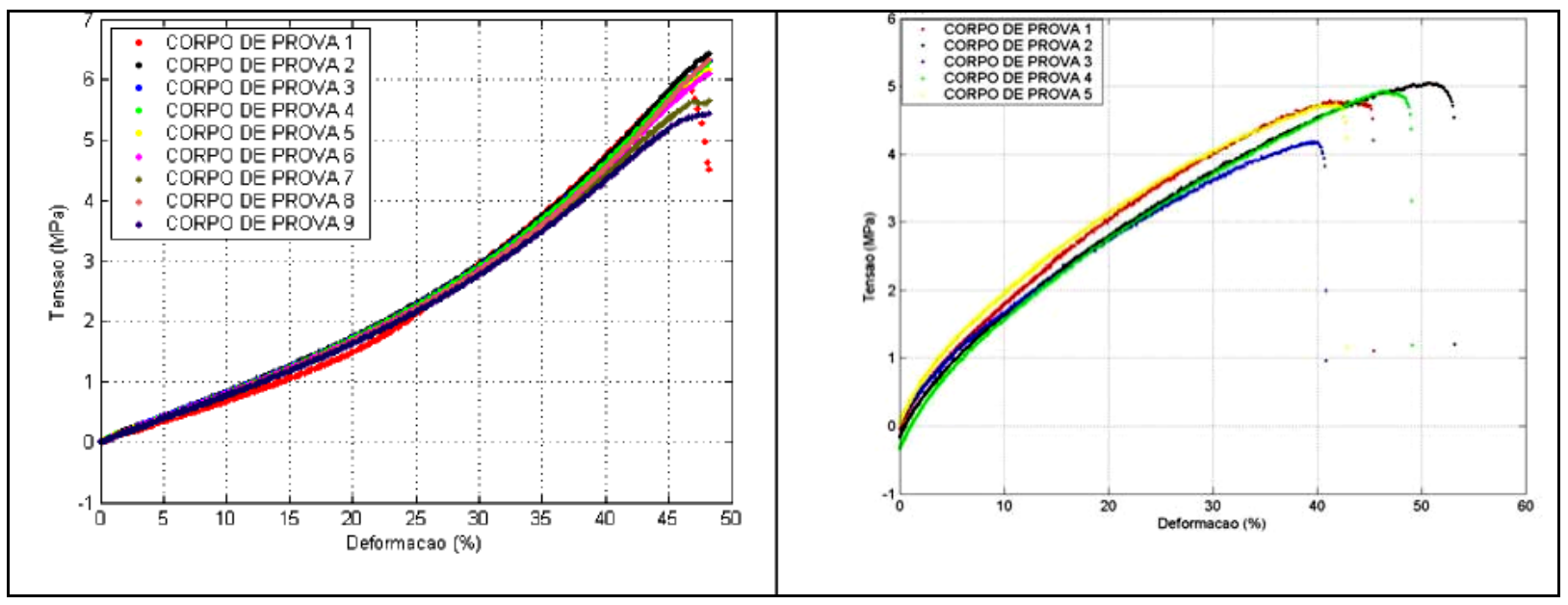

Figura 9.15 - Curvas representativas dos resultados dos ensaios de compressão e tração em compósito de granulometria na zona 3 e teor de resina $15 \%$

Na Figura 9.16 estão as curvas dos ensaios realizados com o compósito de teor de resina de $12 \%$, e composição granulométrica na zona 3.

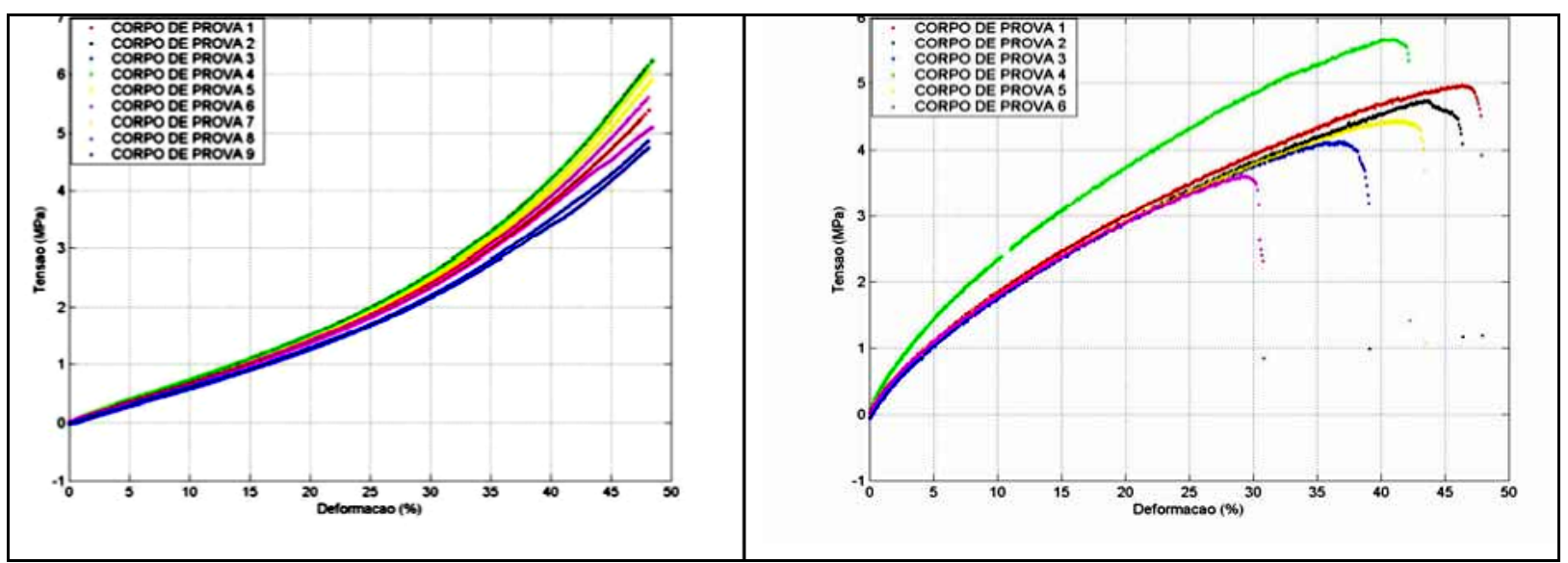

Figura 9.16 - Curvas representativas dos resultados dos ensaios de compressão e tração em compósito de granulometria na zona 3 e teor de resina $12 \%$

A Figura 9.17 apresenta as curvas dos ensaios realizados com o compósito de teor de resina de $15 \%$, e composição granulométrica na zona 4 . 


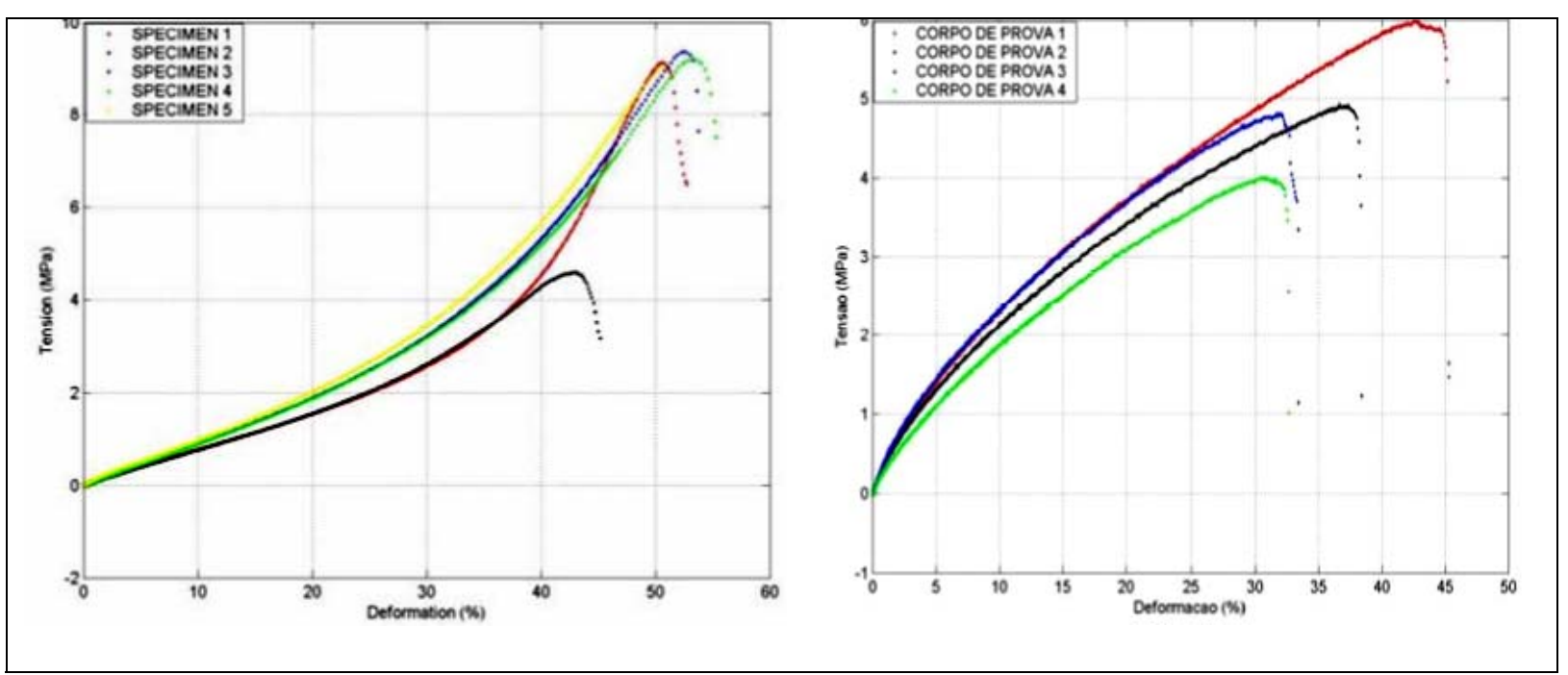

Figura9.17 - Curvas representativas dos resultados dos ensaios de compressão e tração em compósito de granulometria na zona 4 e teor de resina $15 \%$

A Figura 9.18 apresenta as curvas dos ensaios realizados com o compósito de teor de resina de $12 \%$, e composição granulométrica na zona 4 .

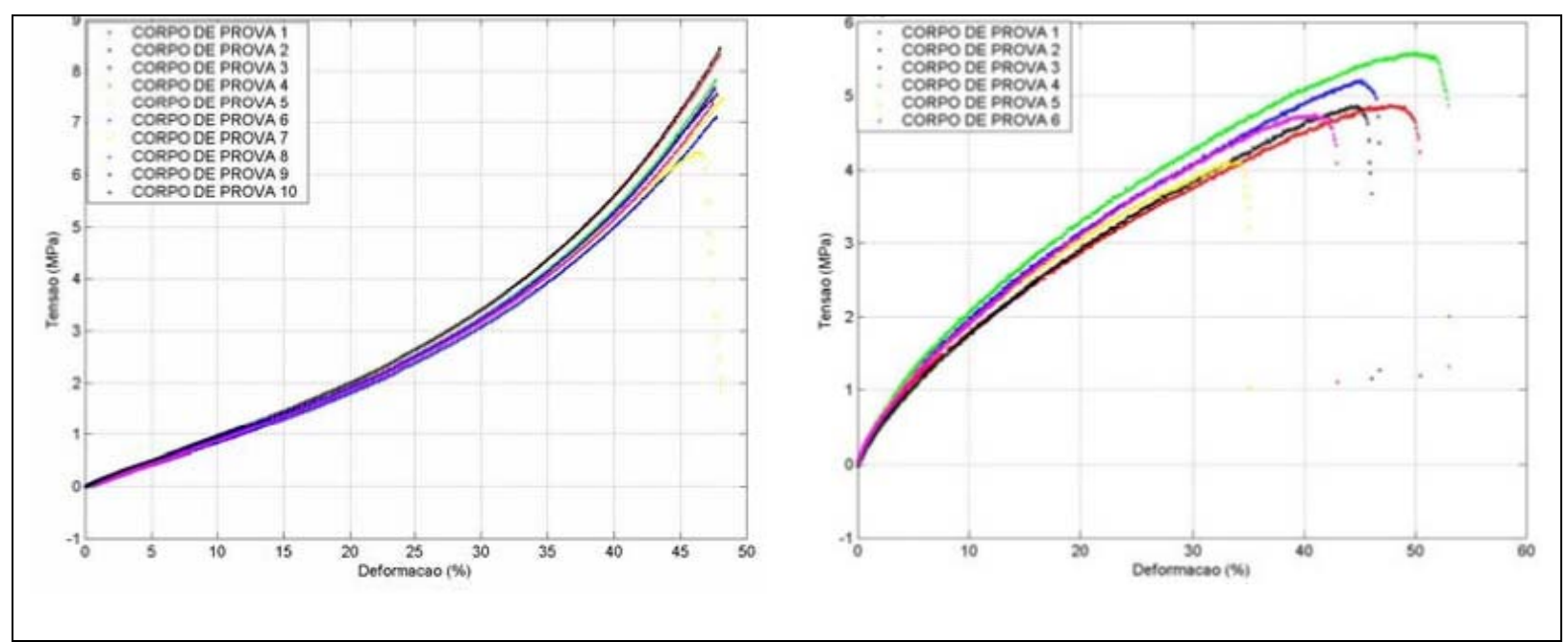

Figura 9.18 - Curvas representativas dos resultados dos ensaios de compressão e tração em compósito de granulometria na zona 4 e teor de resina $12 \%$

Pela análise às figuras anteriores pode-se constatar que os corpos de prova com distribuição granulométrica enquadrada na zona 3 foi os que apresentaram menor dispersão de resultados. 


\subsubsection{Ensaio de Tração}

Para a execução dos ensaios de determinação da resistência à tração foi também necessário o desenvolvimento de moldes metálicos com a possibilidade de comprimir o material introduzido na fôrma, concomitante ao seu aquecimento.

Os valores de ruptura à tração, obtidos nos ensaios inicialmente realizados com base em corpos de prova de dimensões reduzidas, conforme norma ASTM $638 \mathrm{M}$, apresentaram uma grande dispersão, função da pequena seção transversal na região onde ocorre a ruptura. Tratando-se de uma mistura de grãos de borracha com diferentes dimensões, a compacidade foi afetada durante a realização da moldagem pelo "efeito parede", comprometendo a melhor disposição dos grãos.

Isto foi solucionado com o aumento das dimensões do corpo de prova, o que ampliou a sua seção na região central, onde ocorre sua ruptura à tração.

Foram ensaiados os compósitos contendo $12 \%$ e $15 \%$ de resina PU em relação à massa de partículas de borracha segundo a zona 3 e zona 4, definidas anteriormente, e os seus resultados encontram-se nas Figuras 9.13, 9.14, 9.15 e 9.16.

Os compósitos com teores de resina de $18 \%$ e $20 \%$ foram ensaiados em outra máquina universal que aquela utilizada nos ensaios dos compósitos de $12 \%$ e $15 \%$, em razão da impossibilidade de uso do primeiro equipamento. $\mathrm{O}$ inconveniente deste segundo equipamento foi o não fornecimento da distribuição dos pontos relativos a carga e deslocamento, o que impossibilitou a composição dos gráficos tensão x deformação específica para os compósitos com teores de resina de $18 \%$ e $20 \%$ em relação à borracha.

$\mathrm{Na}$ Tabela 9.11 estão os valores médios obtidos nestes ensaios, com os corpos de prova apresentando uma maior dimensão em sua seção transversal central. 
Considerando os valores constantes da Tabela 9.11 pode-se verificar que o compósito com teor de resina de $18 \%$ apresentou resultados satisfatórios com relação ao coeficiente de variação e o desvio padrão, mesmo não sendo aquele com os valores de tensão à tração os mais altos.

Esta condição levou a considerar o compósito com teor de $18 \%$ de resina em relação à borracha como o de maior viabilidade. 
Tabela 9.11 - Valores dos ensaios de tração para os compósitos de 12\%, 15\%, 18\% e 20\%

\begin{tabular}{|c|c|c|c|c|}
\hline Amostras & Força Máx. (N) & Tensão (MPa) & $\begin{array}{c}\text { Mód. } \\
\text { Elasticidade } \\
(\mathrm{MPa}) \\
\end{array}$ & $\begin{array}{c}\text { Deformação } \\
\text { Específica (\%) }\end{array}$ \\
\hline \multirow[t]{2}{*}{$12 \%$} & $\begin{array}{l}8,03 \\
8,02\end{array}$ & $\begin{array}{l}1,53 \\
1,55\end{array}$ & $\begin{array}{l}6,30 \\
6,20\end{array}$ & $\begin{array}{l}50,40 \\
50,20\end{array}$ \\
\hline & 8,05 & 1,52 & 6,40 & 50,50 \\
\hline Média & 8,03 & 1,53 & 6,30 & 50,37 \\
\hline Desvio padrão & 0,02 & 0,02 & 0,10 & 0,15 \\
\hline $\mathrm{CV}$ & 0,0019 & 0,0100 & 0,0159 & 0,0030 \\
\hline \multirow[t]{2}{*}{$15 \%$} & $\begin{array}{l}7,99 \\
7,80\end{array}$ & $\begin{array}{l}1,67 \\
1,66\end{array}$ & $\begin{array}{l}5,90 \\
5,80\end{array}$ & $\begin{array}{l}59,30 \\
58,90\end{array}$ \\
\hline & 7,70 & 1,69 & 5,70 & 58,70 \\
\hline Média & 7,83 & 1,67 & 5,80 & 58,97 \\
\hline Desvio padrão & 0,15 & 0,02 & 0,10 & 0,31 \\
\hline $\mathrm{CV}$ & 0,0188 & 0,0091 & 0,0172 & 0,0052 \\
\hline \multirow[t]{2}{*}{$18 \%$} & $\begin{array}{l}8,81 \\
8,83\end{array}$ & $\begin{array}{l}1,79 \\
1,80\end{array}$ & $\begin{array}{l}6,14 \\
6,10\end{array}$ & $\begin{array}{l}58,70 \\
58,50\end{array}$ \\
\hline & 8,80 & 1,81 & 6,12 & 58,90 \\
\hline Média & 8,81 & 1,80 & 6,12 & 58,70 \\
\hline Desvio padrão & 0,02 & 0,01 & 0,02 & 0,20 \\
\hline $\mathbf{C V}$ & 0,0017 & 0,0056 & 0,0033 & 0,0034 \\
\hline \multirow[t]{2}{*}{$20 \%$} & $\begin{array}{c}10,00 \\
9,90\end{array}$ & $\begin{array}{l}1,98 \\
1,97\end{array}$ & $\begin{array}{l}7,16 \\
7,15\end{array}$ & $\begin{array}{l}58,90 \\
58,80\end{array}$ \\
\hline & 9,87 & 1,95 & 7,18 & 58,70 \\
\hline Média & 9,92 & 1,97 & 7,16 & 58,80 \\
\hline Desvio padrão & 0,07 & 0,02 & 0,02 & 0,10 \\
\hline $\mathrm{CV}$ & 0,0069 & 0,0078 & 0,0021 & 0,0017 \\
\hline
\end{tabular}




\subsection{Ensaio de Rasgamento}

O ensaio de Rasgamento (ASTM D624-00 e 1- Standard test method for tear strenght of conventional vulcanized rubber and thermoplastic elastomers e D1004-94a(2003) Standard test Method for initial tear resistance of plastic film and sheeting foi realizado com os compósitos variando os teores de resina de $12 \%, 15 \%$ e $18 \%$, não sendo executado o ensaio com $20 \%$ por este valor ser descartado considerando seu custo mais elevado em função da maior quantidade de resina utilizada. Os resultados encontram-se constando da Tabela 9.12 .

Tabela 9.12 - Valores encontrados para os compósitos, segundo a Norma ASTM D 624

\begin{tabular}{|c|c|c|}
\hline \multicolumn{2}{|c|}{ Amostras } & $\begin{array}{c}\text { Resistência ao rasgamento } \\
\qquad(\mathrm{N} / \mathrm{mm})\end{array}$ \\
\hline \multirow[t]{6}{*}{$12 \%$} & & 6,72 \\
\hline & & 6,70 \\
\hline & & 6,69 \\
\hline & Média & 6,70 \\
\hline & Desvio padrão & 0,02 \\
\hline & $\mathrm{CV}$ & 0,0023 \\
\hline \multirow[t]{6}{*}{$15 \%$} & & 7,13 \\
\hline & & 7,15 \\
\hline & & 7,14 \\
\hline & Média & 7,14 \\
\hline & Desvio padrão & 0,01 \\
\hline & $\mathrm{CV}$ & 0,0014 \\
\hline \multirow[t]{6}{*}{$18 \%$} & & 7,94 \\
\hline & & 7,93 \\
\hline & & 7,94 \\
\hline & Média & 7,94 \\
\hline & Desvio padrão & 0,01 \\
\hline & $\mathrm{CV}$ & 0,0007 \\
\hline
\end{tabular}


Os resultados obtidos no ensaio de rasgamento apresentam-se coerentes com o resultado obtido para o ensaio de tração, constante do item 9.2.3.2.

\subsection{Resistência ao Fogo}

O ensaio de Inflamabilidade foi realizado de acordo com a norma UL - 94, e sua finalidade foi a de verificar como os compósitos de resina PU e borracha reagem em relação ao fogo incidido horizontalmente.

É sabido que a borracha apresenta grande tendência à combustão sob ação de calor excessivo, condição que pode estar presente em um edifício sujeito a um incêndio.

Este ensaio foi realizado com os quatro tipos de compósitos em estudo, todos eles não puderam receber o grau HB.

Isto leva a crer que a utilização desses compósitos deva ser promovida no interior de edifícios segundo critérios de projeto que possibilitem a adequada proteção dos usuários.

\subsection{Ensaio de Dureza}

Este ensaio foi realizado utilizando um durômetro WULTEST com ponta de prova para escala SHORE “A”, sempre à temperatura ambiente, segundo a ASTM D 2240-9 7 for Rubber Property- Durometer Hardeness. Os valores obtidos com o compósito constam da Tabela 9.13, e não diferem substancialmente daqueles obtidos para os materiais borracha e resina PU, individualmente. 
Tabela 9.13 - Valores de dureza encontrados para o pneu e o compósito

\begin{tabular}{lc}
\hline \multicolumn{1}{c}{ Composto } & Dureza na Escala Shore “A” \\
\hline Pneu Integral & 73 \\
Borracha/Resina $12 \%, 15 \%, 18 \%$ e $20 \%$ & 75 \\
\hline
\end{tabular}

\subsection{Determinação da Densidade}

Este ensaio foi realizado segundo a ASTM D 792-Density and Specific Gravity (Relative Density) of Plastics by Displacement.

Por se tratar de um material com baixíssima absorção de água, a densidade foi obtida através da relação entre massa e volume de corpos de prova. A massa foi tomada em balança com precisão de $0,001 \mathrm{~g}$ e o volume, através de paquímetro com precisão de $0,01 \mathrm{~mm}$.

Tabela 9.14 - Valores de densidade encontrados para o pneu e o compósito

\begin{tabular}{|c|c|}
\hline Amostras & 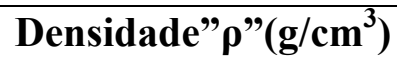 \\
\hline Borracha/Resina $12 \%, 15 \%, 18 \%$ e $20 \%$ & 1,16 \\
\hline Pneu Integral & 1,17 \\
\hline
\end{tabular}

\subsection{Análise Dinâmico Mecânica (DMA)}

Os gráficos constantes das Figuras 9.19, a seguir, apresentam os valores de E', E', e Tan $\delta$ para os dois materiais puros, ou seja, a borracha de pneu agrícola aleatoriamente considerado e a resina PU de origem vegetal, utilizada neste estudo como aglomerante. A variação do teor de resina PU em relação à borracha em 12\%, 15\%, 18\% e 20\% decorreu de ensaios preliminares para a fixação destes conteúdos, com base nos parâmetros de desempenho dos compósitos, e estão constando da Figura 9.20. 


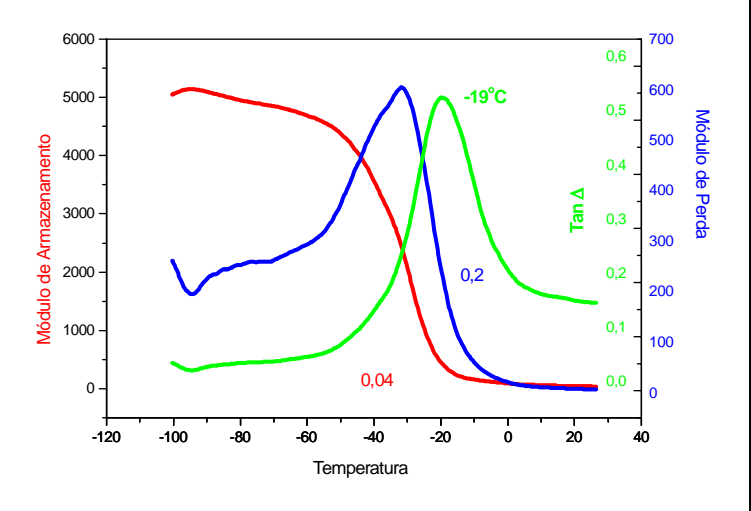

Figura 9.19a - Resultado da borracha de pneu

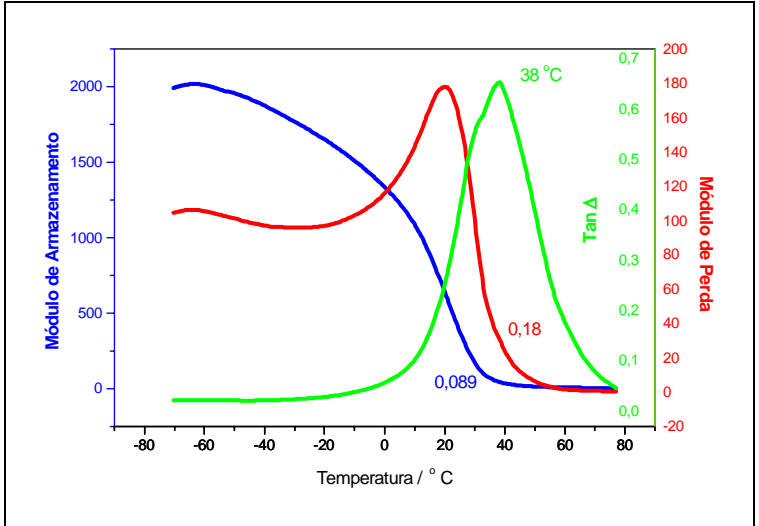

Figura 9.19b - Resultado da resina PU

Figura 9.19 - Curvas obtidas para o pneu e a resina PU

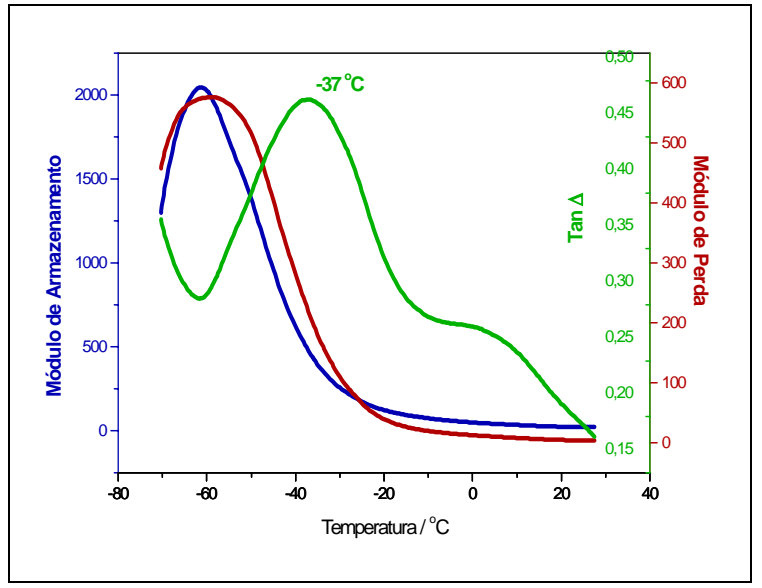

Figura 9.20a - Resultado do compósito com $12 \%$ de resina

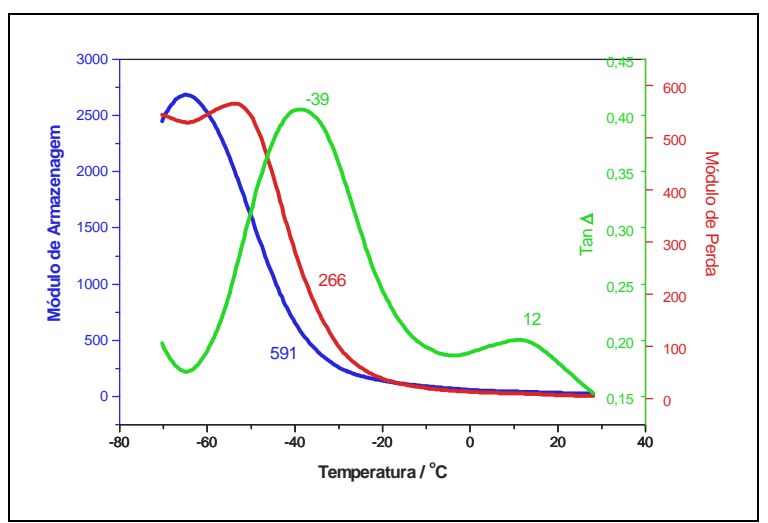

Figura 9.20c - Compósito com 18\% de resina

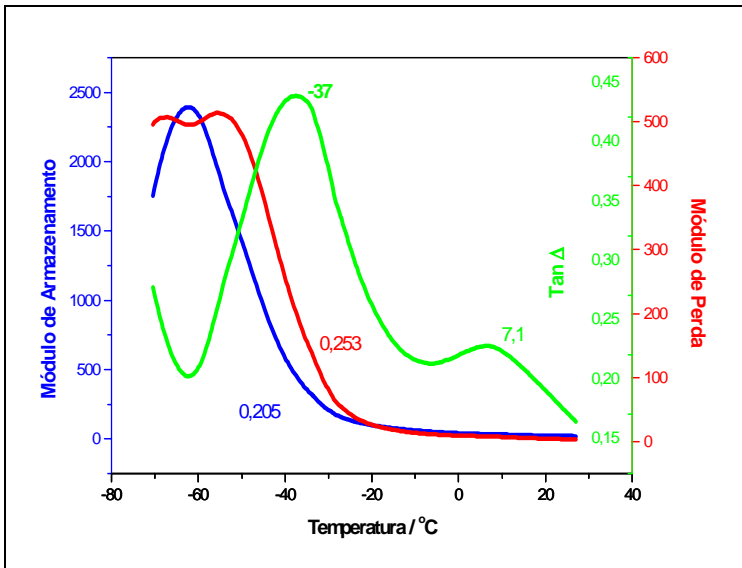

Figura 9.20b - Resultado do compósito com $15 \%$ de resina

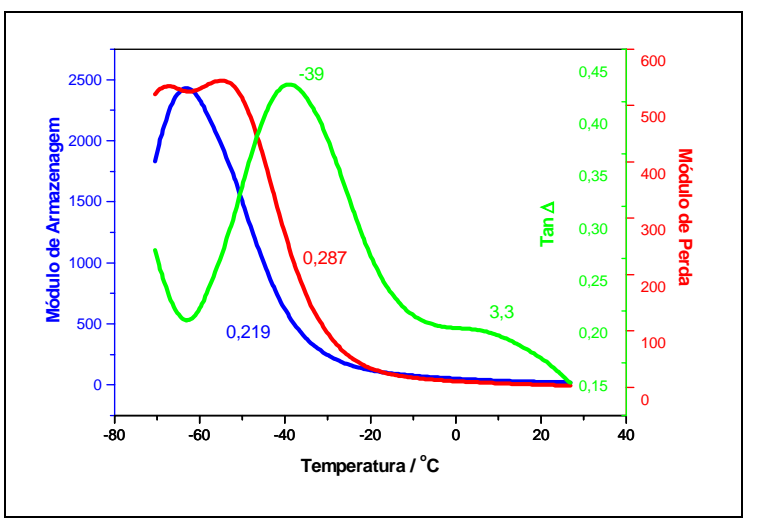

Figura 9.20d - Compósito com 20\% de resina

Figura 9.20 - Curvas obtidas para os compósitos com teores de resina de 12\%, 15\%, 18\% e de $20 \%$

A Tabela 9.15 apresenta os resultados obtidos para os materiais ensaiados, considerando que as partículas de borracha tiveram sua granulometria enquadrada conforme a Zona 3, definida anteriormente. 
Tabela 9.15 - Valores dos Módulos de elasticidade (E), de armazenamento (E'), e de perda (E') obtidos com os compósitos, a resina e o pneu

\begin{tabular}{cc}
\hline E'(MPa) novo & E'(MPa) novo \\
\hline 25,76 & 5,584 \\
30,07 & 6,646 \\
30,13 & 7,009 \\
28,02 & 6,43 \\
\hline
\end{tabular}

\begin{tabular}{|c|c|c|c|}
\hline $\operatorname{Amostra}\left(25^{\circ} \mathrm{C}\right)$ & $\begin{array}{l}\text { E' (Módulo de } \\
\text { Elast. de } \\
\text { Armazenamento } \\
\text { MPa) }\end{array}$ & $\begin{array}{l}\text { E" (Módulo de } \\
\text { Elast. de Perda } \\
\text { MPa) }\end{array}$ & $\operatorname{Tan} \delta\left({ }^{0} \mathrm{C}\right)$ \\
\hline Pneu Puro & 39,3 & 6,4 & -19 \\
\hline PU & 375,0 & 157,6 & 38 \\
\hline Compósito $12 \%(\mathrm{~m} / \mathrm{m})$ & 25,76 & 5,584 & -37 \\
\hline Compósito 15\% (m/m) & 30,07 & 6,646 & -37 \\
\hline Compósito 18\% (m/m) & 30,13 & 7,009 & -39 \\
\hline Compósito $20 \%(\mathrm{~m} / \mathrm{m})$ & 28,02 & 6,43 & -39 \\
\hline
\end{tabular}

Na tabela 9.15 estão apresentados os valores encontrados para Tan $\delta$, os módulos de armazenamento E' e perda dos compósitos E" de materiais puros (borracha e resina PU) e os compósitos com variação do teor de resina de $12 \% 15 \%$ 18\% e $20 \%$.

Na Figura 9.20 são apresentadas curvas do módulo de armazenamento, módulo de perda e Tan $\delta$ em função da variação da temperatura, nos compósitos borracha e resina poliuretanica nos diferentes teores de resina.

Na Figura 9.19a, a transição vítrea da borracha original do pneu ocorreu à temperatura de $-19^{\circ} \mathrm{C}$, na Figura $9.19 \mathrm{~b}$ a transição vítrea da resina poliuretana pura ocorreu a $38^{\circ} \mathrm{C} . \mathrm{Na}$ Figura 19.20 a temperatura de transição vítrea no compósito de borracha com resina PU de 
$18 \%$ e $20 \%$ seu valor reduziu-se para $-39^{\circ} \mathrm{C}$, e para os teores de $12 \%$ e $15 \%$ seu valor foi de $37^{\circ} \mathrm{C}$.

A resina poliuretana, embora esteja presente no compósito em quantidades que variam de $12 \%$ a 20\%, influência as propriedades mecânicas do compósito, e uma possível explicação para a diminuição da temperatura de transição vítrea pode estar na presença de vazios na interface borracha x PU. Falhas entre a resina PU e as partículas de borracha podem ocorrer em função de diferentes causas como por uma força de prensagem deficiente, incorporação de ar durante a mistura da resina com a borracha, descontinuidade do filme de resina que envolve as partículas de borracha.

\subsection{Termogravimetria (TG)}

Na Figura 9.21 são apresentadas as curvas termogravimétricas dos compósitos em diferentes composições (resina PU x borracha) e comparados com as amostras dos materiais puros como o pneu e resina PU, separadamente.

As curvas TG para os diferentes compósitos de borracha-resina poliuretana em presença do ar atmosférico apresentaram três etapas de decomposição térmica. Na Tabela 9.16 estão colocados os valores de TG dos compósitos e dos materiais puros (borracha e resina PU). A primeira etapa ocorreu uma perda de massa da ordem de $7 \%$ no intervalo de 110 a $320^{\circ} \mathrm{C}$, na segunda etapa ocorreu uma perda de massa da ordem de $53 \%$ no intervalo de 320 a $500^{\circ} \mathrm{C}$, e na terceira e última etapa ocorreu uma perda de massa da ordem de $35 \%$ no intervalo de temperatura 500 a $600^{\circ} \mathrm{C}$. Foi observado que quanto maior a percentagem de resina PU, maior a perda de massa na primeira etapa de decomposição térmica do compósito que ocorre entre 100 e $350^{\circ} \mathrm{C}$. 
Todos os compósitos apresentaram um resíduo da ordem de 5 a $6 \%$ na temperatura de $700^{\circ} \mathrm{C}$. Este resíduo foi caracterizado por espectroscopia na região do infravermelho como sendo sulfato de zinco que está relacionado com a oxidação do enxofre, presente na composição da borracha após a queima do resíduo (negro de fumo, material constituinte da borracha do pneu). Não se notaram diferenças significativas nos perfis e nos resultados individuais de cada grupo de amostras, em face da predominância de borracha nas três composições consideradas. As segunda e terceira perdas de massa, relacionadas à decomposição dos polímeros e a queima do resíduo (negro de fumo), respectivamente, apresentaram temperaturas e porcentagem de perda aproximada para todas as amostras de compósito.

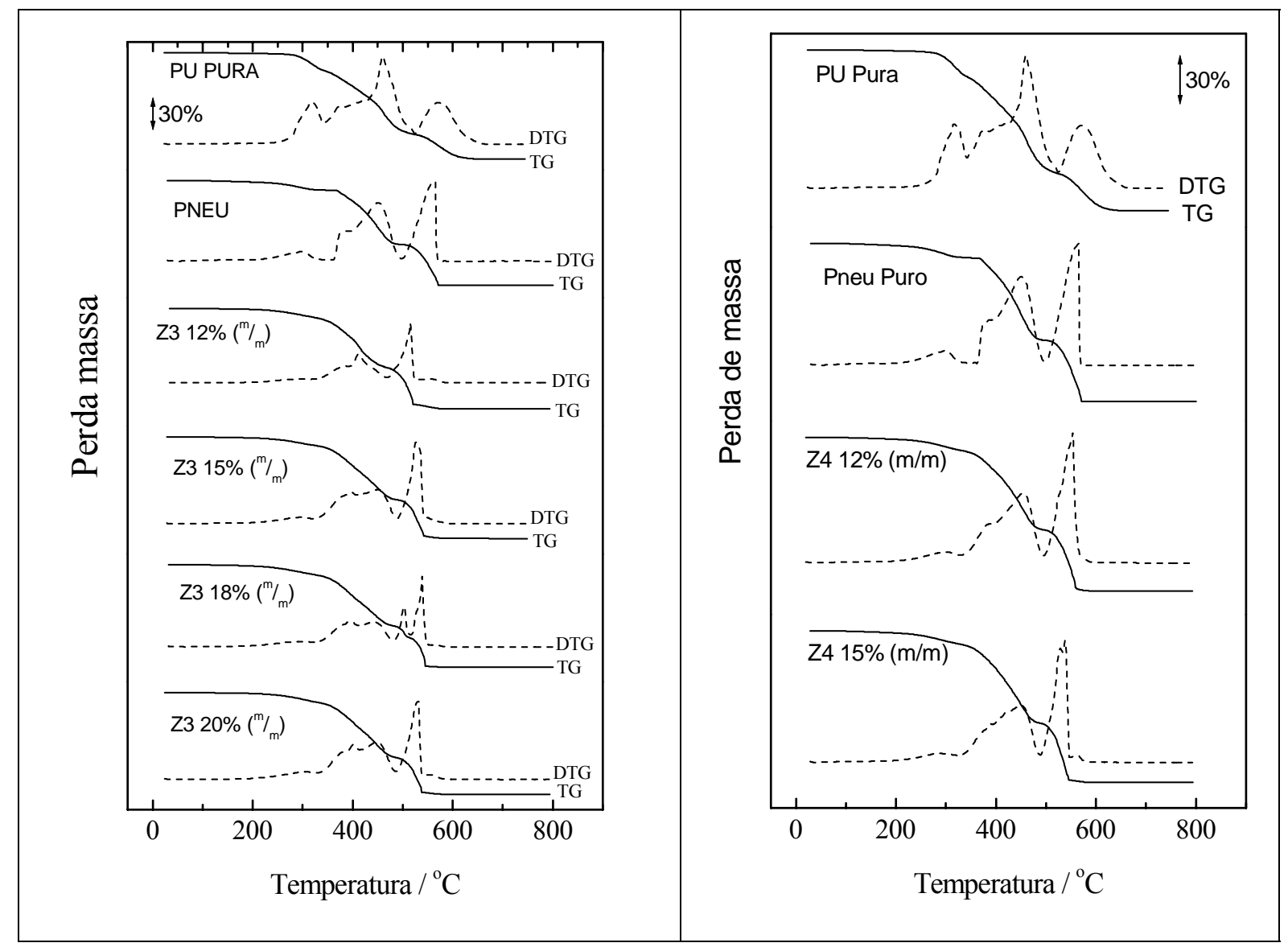

Figura 9.21 - Curva TG para o pneu puro, a resina poliuretana e dos compósitos com teores de resina em relação à borracha de: $12 \%, 15 \%, 18 \%$ e $20 \%$ para a zona 3 e $12 \%$ e $15 \%$ para a zona 4. (Razão de aquecimento de $10^{\circ} \mathrm{C} \mathrm{min}^{-1}$, fluxo de ar de $100 \mathrm{~mL} \mathrm{~min}^{-1}$ ). 
Tabela 9.16 - Valores obtidos no ensaio TG para os materiais puros e compósito segundo composição granulométrica nas zonas 3 e 4

\begin{tabular}{|c|c|c|c|c|c|c|c|c|}
\hline Amostra & $\begin{array}{c}1^{\mathrm{a}} \\
\text { Perda } \\
(\%)\end{array}$ & $\begin{array}{c}\text { Intervalo } \\
\left({ }^{\circ} \mathrm{C}\right)\end{array}$ & $\begin{array}{c}2^{\mathrm{a}} \\
\text { Perda } \\
(\%)\end{array}$ & $\begin{array}{c}\text { Intervalo } \\
\left({ }^{\circ} \mathbf{C}\right)\end{array}$ & $\begin{array}{c}3^{\mathrm{a}} \\
\text { Perda } \\
(\%)\end{array}$ & $\begin{array}{c}\text { Intervalo } \\
\left({ }^{\circ} \mathbf{C}\right)\end{array}$ & $\begin{array}{c}\text { Resíduo } \\
\mathbf{( \% )}\end{array}$ & $\begin{array}{c}\text { Temperatura } \\
\left({ }^{\circ} \mathbf{C}\right)\end{array}$ \\
\hline PU- Pura & 16,6 & $217-340$ & 60,2 & $340-525$ & 23,0 & $525-680$ & 0,0 & - \\
\hline Pneu & 8,5 & $55-350$ & 50,1 & $350-500$ & 39,0 & $500-600$ & 3,0 & 600 \\
\hline \multicolumn{9}{|l|}{ Z4 12\% - } \\
\hline 1,16 & 8,1 & $70-330$ & 49,3 & $330-495$ & 37,9 & $495-600$ & 4,7 & 600 \\
\hline \multicolumn{9}{|l|}{ Z4 15\% - } \\
\hline 1,16 & 7,8 & $55-320$ & 49,5 & $320-490$ & 36,7 & $490-600$ & 6,0 & 600 \\
\hline \multicolumn{9}{|l|}{ Z3 12\% - } \\
\hline 1,16 & 7,8 & $65-315$ & 47,7 & $315-470$ & 38,7 & $470-600$ & 5,7 & 600 \\
\hline \multicolumn{9}{|l|}{ Z3 15\% - } \\
\hline 1,16 & 7,7 & $70-320$ & 51,5 & $320-490$ & 36,2 & $490-700$ & 4,5 & 700 \\
\hline \multicolumn{9}{|l|}{ Z3 18\% - } \\
\hline 1,16 & 9,3 & $50-320$ & 48,3 & $320-480$ & 38,7 & $480-700$ & 3,8 & 700 \\
\hline \multicolumn{9}{|l|}{ Z3 20\% - } \\
\hline 1,16 & 9,2 & $70-330$ & 51,6 & $330-485$ & 34,7 & $485-600$ & 4,3 & 600 \\
\hline
\end{tabular}

\subsection{Caracterização do Resíduo por FT-IR}

Os resíduos obtidos nos ensaios termogravimétricos foram caracterizados por espectroscopia na região do infravermelho como sendo sulfato de zinco, que está relacionado com a oxidação do enxofre, presente na composição da borracha após a queima do resíduo (negro de fumo), constante da Figura 9.22. 


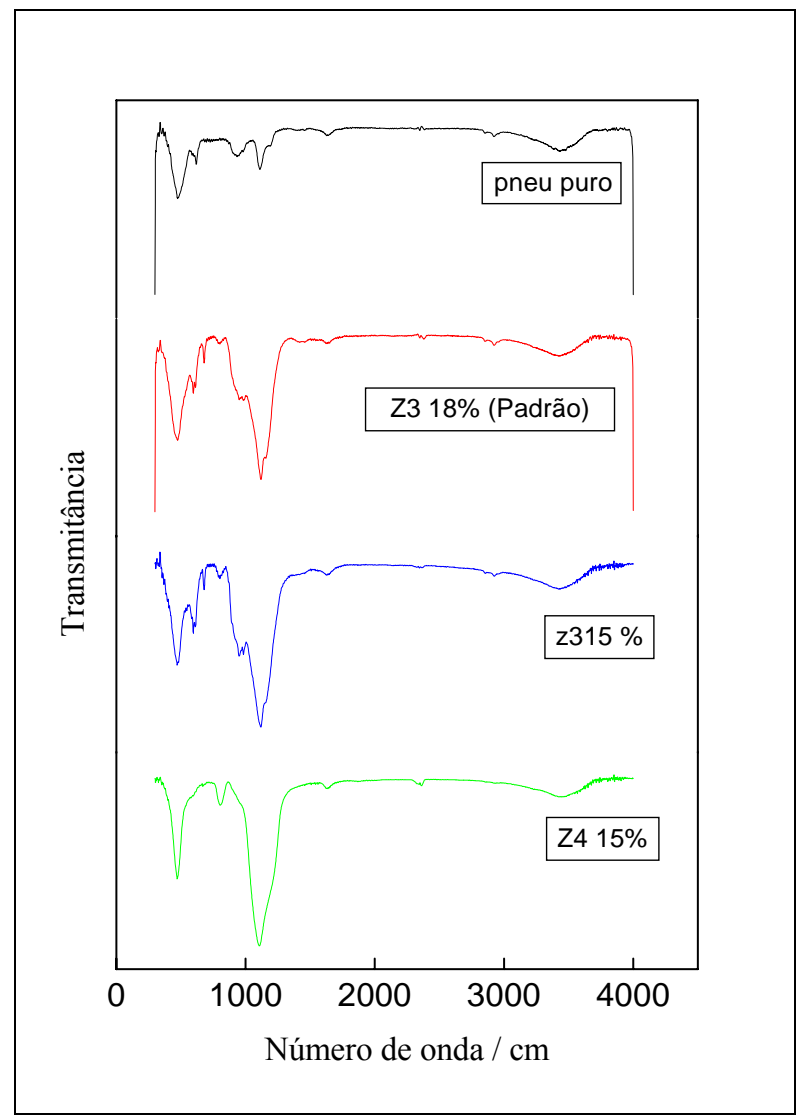

Figura 9.22 - Espectro na região do infravermelho dos resíduos dos diferentes compósitos obtidos a $800^{\circ} \mathrm{C}$ em atmosfera de ar

\subsection{Resistência ao Impacto-Ensaio Charpy}

Na Tabela 9.17 são apresentados os resultados do ensaio de Charpy, cujas seções transversais dos corpos de prova fraturados estão constando da Figura 9.23.

Estas seções que foram rompidas no ensaio tiveram sua superfície micrografada com o objetivo de melhor visualizar a fratura ocorrida nos corpos de prova. 


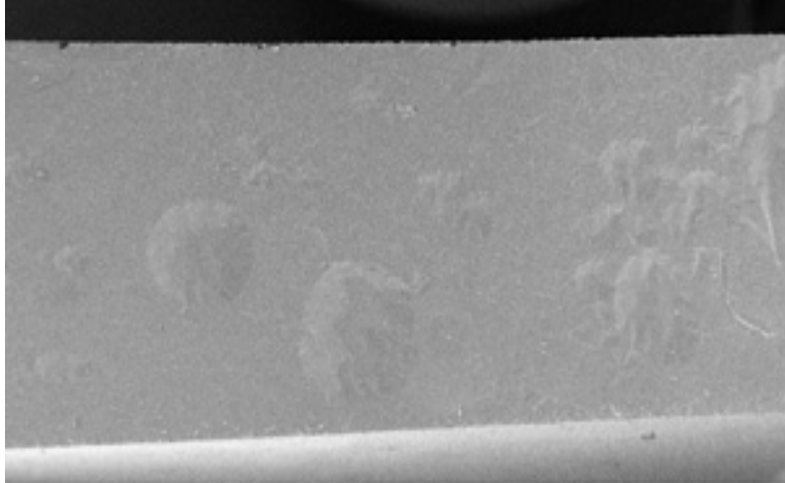

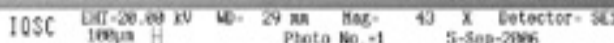

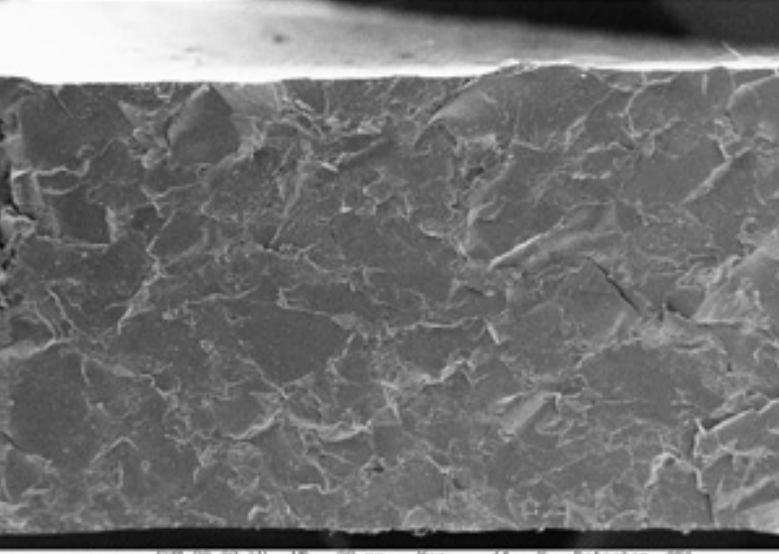

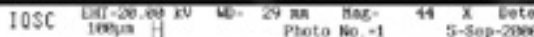
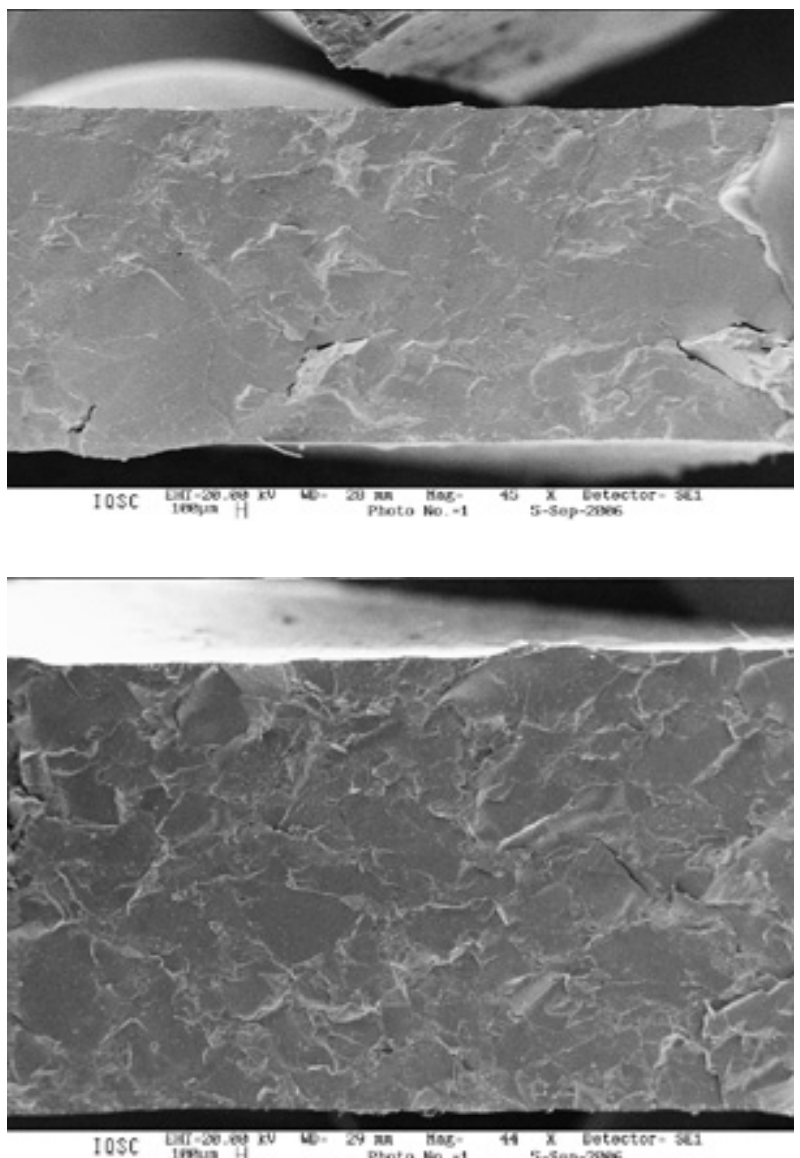

Figura 9.23 - Seções fraturadas dos corpos de prova submetidos ao ensaio Charpy

Tabela 9.17 - Resultados obtidos nos ensaio de impacto Charpy

\begin{tabular}{lccccc}
\hline Amostras & $\begin{array}{c}\mathbf{P - P u r o} \\
\left(\mathbf{K J} / \mathbf{m}^{2}\right)\end{array}$ & $\begin{array}{c}\mathbf{Z 3 - 1 2 \%} \\
\left.\mathbf{( K J} / \mathbf{m}^{2}\right)\end{array}$ & $\begin{array}{c}\mathbf{Z 3 - 1 5 \%} \\
\left(\mathbf{K J} / \mathbf{m}^{2}\right)\end{array}$ & $\begin{array}{c}\mathbf{Z 3 - 1 8 \%} \\
\left(\mathbf{K J} / \mathbf{m}^{2}\right)\end{array}$ & $\begin{array}{c}\mathbf{Z 3 - 2 0 \%} \\
\left(\mathbf{K J} / \mathbf{m}^{2}\right)\end{array}$ \\
& 2,39 & 3,47 & 3,71 & 3,66 & 3,6 \\
& 2,42 & 3,95 & 4,05 & 4,01 & 3,98 \\
& 2,23 & 3,79 & 4,06 & 4,17 & 3,97 \\
& 2,37 & 3,4 & 3,84 & 3,96 & 3,81 \\
& 2,34 & 3,64 & 3,9 & 3,93 & 3,8 \\
& 2,57 & 3,53 & 3,61 & 4,05 & 4,1 \\
\hline Média & 2,39 & 3,63 & 3,86 & 3,96 & 3,88 \\
\hline Desvio padrão & 0,111 & 0,208 & 0,181 & 0,171 & 0,177 \\
\hline C.V. & 0,0464 & 0,0573 & 0,0469 & 0,0432 & 0,0456
\end{tabular}


As análises descritivas e analíticas foram calculadas para o ensaio do impacto Charpy. $\mathrm{Na}$ analise descritiva calculou-se a média, desvio-padrão e coeficiente de variação, e nesta análise a dosagem que menos variou foi a de $18 \%$

Tabela 9.18 - Análise estatística dos resultados do Ensaio Charpy

\begin{tabular}{lcc}
\hline \multicolumn{1}{c}{ Comparações } & Teste Estatístico & Charpy (p-valor) \\
\hline z3-18\%;12\%;15\%;20\% & ANOVA & $0,0322(\mathrm{~S})$ \\
z3-18\% e 12\% & t de student & $0,0063(\mathrm{~S})$ \\
z3-18\% e $15 \%$ & t de student & 0,1699 (NS) \\
z3-18\% e 20\% & t de student & 0,2038 (NS) \\
\hline
\end{tabular}

$\mathrm{Na}$ avaliação analítica a hipóteses de nulidade, que postula não haver diferença entre as dosagens, foi testada em todos os casos com nível de significância de 0,05. Para a Análise de Variância, ANOVA - técnica estatística que subdivide a variabilidade total de um conjunto de dados em seus componentes e estabelece se as médias de vários grupos são estatisticamente diferentes, entre as distintas dosagens obteve-se diferença significativa entre as médias com p-valor (valor associado a uma estatística de teste que indica a probabilidade de um valor tão ou mais extremo que o observado, ocorrer apenas por acaso em varias repetições do experimento) foi de 0,0322 .

$\mathrm{Na}$ aplicação do teste $\mathrm{t}$ de student, quando comparou-se todas as dosagens, e segundo a Tabela 9.18, obteve-se diferença significativa entre as médias de Z3-18\% e Z3-12\%, com pvalor 0,0063 ; entre as médias na Z3-18\% e Z3-15\% obteve-se diferença não significativa, com p-valor 0,1699; entre as médias Z3-18\% e Z3-20\% obteve-se também diferença não significativa, com p-valor 0,2038 .

As condições acima verificadas demonstram que o compósito com 18\% de resina PU em relação à borracha não apresenta variação significativa entre o de teores de $15 \%$ e $20 \%$, mas tem diferença com relação ao teor de resina de $12 \%$. 


\subsection{Ensaio de Resistividade Elétrica}

\subsubsection{Rigidez Dielétrica}

A rigidez dielétrica corresponde a um campo elétrico máximo que o material suporta quando submetido a uma determinada tensão. Na Tabela 9.19 estão apresentados os valores obtidos para diferentes materiais e na Tabela 9.20 os resultados encontrados para os compósitos com teores de resina de $12 \%, 15 \%$ e $18 \%$.

Tabela 9.19 - Valores obtidos para diferentes materiais conhecidos

\begin{tabular}{lcc}
\hline \multicolumn{1}{c}{ Tipo de Material } & Constante dielétrica " $\boldsymbol{~}$ & Rigidez dielétrica V/mm \\
\hline Ar & 1 & 3000 \\
Baquelite & 5 & 21000 \\
Vidro & 6 & 35000 \\
Mica & 5 & 60000 \\
Óleo & 4 & 10000 \\
Papel & 2,5 & 20000 \\
Borracha & 3 & 25000 \\
Teflon & 2 & 60000 \\
\hline
\end{tabular}

Fonte: http://www.dsee.fee.unicamp.br/ sato/ET515/node15.htm. Acesso em: jul./2008 
Tabela 9.20 - Resultados dos ensaios elétricos realizados nos compósitos

\begin{tabular}{|c|c|c|c|}
\hline Amostras & Espessura (mm) & $\begin{array}{l}\text { Tensão de Ruptura } \\
\text { (kV) }\end{array}$ & $\begin{array}{c}\text { Rigidez Dielétrica } \\
(\mathrm{kV} / \mathbf{m m})\end{array}$ \\
\hline \multirow[t]{6}{*}{$12 \%$} & 2,6500 & 3,1800 & 1,2000 \\
\hline & 2,6500 & 3,1200 & 1,1774 \\
\hline & 2,6500 & 3,1500 & 1,1887 \\
\hline & Média & 3,1500 & 1,1887 \\
\hline & Desvio padrão & 0,0300 & 0,0113 \\
\hline & C.V. & 0,0095 & 0,0095 \\
\hline \multirow[t]{6}{*}{$15 \%$} & 2,6600 & 4,2500 & 1,5977 \\
\hline & 2,6600 & 4,3000 & 1,6165 \\
\hline & 2,6600 & 4,2600 & 1,6015 \\
\hline & Média & 4,2700 & 1,6053 \\
\hline & Desvio padrão & 0,0265 & 0,0099 \\
\hline & C.V. & 0,0062 & 0,0062 \\
\hline \multirow[t]{6}{*}{$18 \%$} & 2,6800 & 4,5800 & 1,7090 \\
\hline & 2,6800 & 4,6100 & 1,7201 \\
\hline & 2,6800 & 4,5900 & 1,7127 \\
\hline & Média & 4,5933 & 1,7139 \\
\hline & Desvio padrão & 0,0153 & 0,0057 \\
\hline & C.V. & 0,0033 & 0,0033 \\
\hline
\end{tabular}

A princípio imaginou-se que o compósito apresentaria boa capacidade de isolamento às cargas elétricas por ser a borracha um material de elevada resistividade elétrica. Todavia essa condição não se concretizou na prática em razão de que no compósito estão presentes, além das partículas de borracha e resina PU, fragmentos de fibras de aço e de fibras de nylon, e as primeiras tendem a permitir a transmissão de carga elétrica conforme possam estar distribuídas ao longo da seção transversal do compósito.

Como foi constatado neste ensaio, na Tabela 9.19, a rigidez dielétrica da borracha é de $25 \mathrm{kV} / \mathrm{mm}$, e os valores obtidos para os compósitos de $12 \%, 15 \%$ e $18 \%$ foram de 1,19 $\mathrm{kV} / \mathrm{mm}, 1,60 \mathrm{kV} / \mathrm{mm}$ e $1,71 \mathrm{kV} / \mathrm{mm}$, respectivamente. 
Estes valores não invalidam a utilização dos compósitos de borracha e resina PU, pelo contrário, possibilitam a descarga de eletricidade estática, condição requerida em placas de revestimento de pisos, por exemplo.

\subsection{Desempenho do Compósito com Relação à Durabilidade}

\subsubsection{Ensaio de Abrasão}

Este ensaio foi realizado com a intenção de avaliar as propriedades do compósito quando submetido ao desgaste por abrasão.

Conforme foi referido anteriormente no Capítulo 8, não foi possível realizar o ensaio preconizado na ASTM, o que levou a utilização de ensaio adaptando a Norma BS 812.

O comportamento de materiais comercializados como a placa de borracha utilizada no revestimento de pisos e também uma placa de porcelanato e uma placa de cerâmica esmaltada com resistência a abrasão PEI 5, foram analisados para servir de referência ao compósito em estudo.

Na Tabela 9.21 estão os valores obtidos no ensaio, no qual são determinadas as massas inicial e final dos corpos de prova, cuja diferença percentual vai indicar a resistência ao desgaste do material ensaiado. 
Tabela 9.21 - Valores obtidos no ensaio de abrasão, utilizando areia de diâmetro variando de $0,1 \mathrm{~mm}$ a $0,6 \mathrm{~mm}$

\begin{tabular}{lccc}
\hline Compósito & Massa inicial do c.p. & Massa final & $\begin{array}{c}\text { Ciclos/Carga } \\
\text { Aplicada }\end{array}$ \\
\hline Compósito 20\% & 71,65 & 71,56 & $1000 / 2 \mathrm{~kg}$ \\
Compósito 20\% & 68,4 & 68,27 & $1000 / 2 \mathrm{~kg}$ \\
Compósito 18\% & 75,57 & 75,44 & $1000 / 2 \mathrm{~kg}$ \\
Compósito 18\% & 80,86 & 80,54 & $1000 / 2 \mathrm{~kg}$ \\
Compósito 15\% & 81,26 & 81,19 & $1000 / 2 \mathrm{~kg}$ \\
Compósito 15\% & 80,84 & 80,77 & $1000 / 2 \mathrm{~kg}$ \\
Compósito 12\% & 79,97 & 79,94 & $1000 / 2 \mathrm{~kg}$ \\
Compósito 12\% & 73,3 & 73,27 & $1000 / 2 \mathrm{~kg}$ \\
Piso & 61,35 & 61,32 & $1000 / 2 \mathrm{~kg}$ \\
Piso & 53,62 & 53,58 & $1000 / 2 \mathrm{~kg}$ \\
PEI 5 & 91,5 & 81,07 & $500 / 2 \mathrm{~kg} *$ \\
PEI 5 & 92,23 & 81,41 & $500 / 2 \mathrm{~kg} *$ \\
Porcelanato & 104,72 & 103,3 & $500 / 2 \mathrm{~kg} *$ \\
Porcelanato & 106,59 & 105,62 & $500 / 2 \mathrm{~kg} *$ \\
\hline
\end{tabular}

Tabela 9.22 - Análise dos resultados obtidos

\begin{tabular}{ccccc}
\hline Amostra & Massa inicial & Massa final & $\begin{array}{c}\text { Perda Massa } \\
(\%)\end{array}$ & Valor Médio \\
\hline \multirow{2}{*}{$\mathbf{1 2 \%}$} & 73,3000 & 73,2700 & 0,041 & \\
& 79,9700 & 79,9400 & 0,037 & 0,039 \\
$\mathbf{1 5 \%}$ & 81,2600 & 81,1900 & 0,086 & \\
& 80,8400 & 80,7700 & 0,087 & 0,0865 \\
$\mathbf{1 8 \%}$ & 80,8600 & 80,8400 & 0,025 & \\
& 75,5700 & 75,5400 & 0,04 & \\
$\mathbf{2 0 \%}$ & 71,6500 & 71,5600 & 0,126 & 0,158 \\
& 68,4000 & 68,2700 & 0,19 & \\
PISO & 61,3500 & 61,3200 & 0,05 & 0,062 \\
& 53,6200 & 53,5800 & 0,074 & 11,56 \\
\multirow{2}{*}{ PEI 5 } & 91,5000 & 81,0700 & 11,39 & \\
& 92,2300 & 81,4100 & 11,73 & 1,18 \\
\hline
\end{tabular}


Pela análise dos dados relativos à Tabela 9.22 pode-se verificar que os compósitos constituídos de borracha e resina PU apresentaram um bom desempenho com relação ao piso comercial de borracha, com 1000 ciclos e carga de 2,0 kg, especialmente o de $18 \%$ de teor de resina, que foi o de melhor resultado.

Os pisos de material cerâmico e porcelanato apresentaram desgaste mais pronunciado que os de borracha, mesmo tendo sido submetidos à metade do número de ciclos.

\subsubsection{Ensaio de Resistência ao Intemperismo (Raios Ultra-Violeta)}

O objetivo deste ensaio foi o de avaliar o desempenho do compósito quando submetido ao intemperismo, especialmente aos raios UV.

Os corpos de prova mantidos na câmara de envelhecimento acelerado foram ensaiados por meio da técnica do DMA, e comparados com aqueles corpos de prova deixados no ambiente normal, em laboratório.

Este ensaio mostrou-se satisfatório para a detecção dos efeitos ocasionados aos corpos de prova, pois após 2000 horas na câmara pode-se avaliar em maior profundidade as suas propriedades mecânicas.

A Figura 9.24 apresenta o gráfico DMA do compósito com teor de resina de 12\%, antes e depois de ser submetido à câmara de envelhecimento. A Figura 9.25 apresenta o gráfico DMA do compósito com teor de resina de $15 \%$, antes e depois de ser submetido à câmara de envelhecimento. A Figura 9.26 apresenta o gráfico DMA do compósito com teor de resina de $18 \%$, antes e depois de ser submetido à câmara de envelhecimento. A Figura 9.27 apresenta o gráfico DMA do compósito com teor de resina de $20 \%$, antes e depois de ser submetido à câmara de envelhecimento. 
A Tabela 9.23 apresenta os valores de transição vítrea dos compósitos antes e depois de serem sujeitos a câmara de intemperismo.

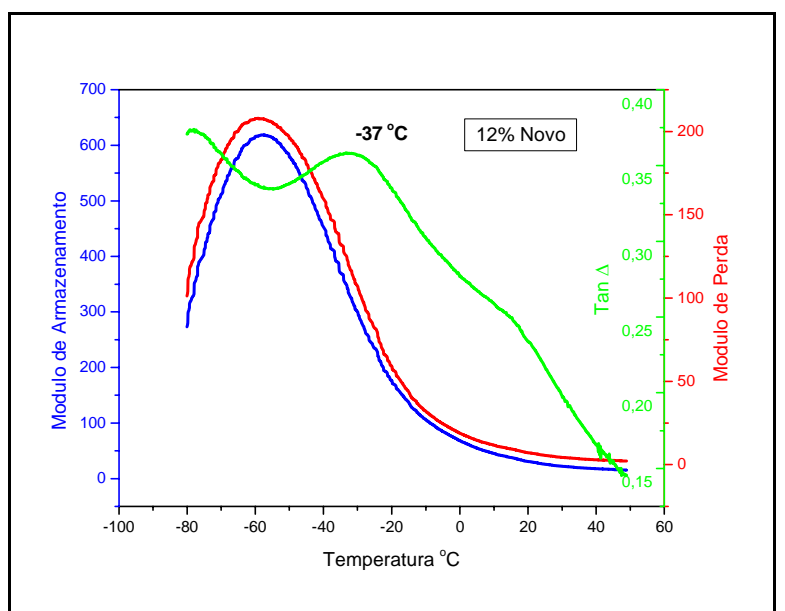

Figura 9.24 a - Compósito com teor $12 \%$ em ambiente normal

Figura 9.24 - Compósito com teor 12\%

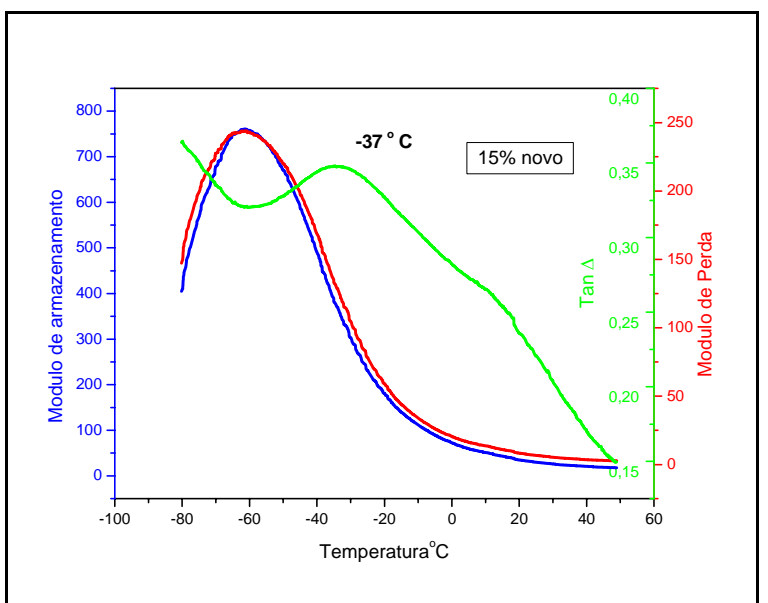

Figura 9.25 a: Compósito com teor $15 \%$ em ambiente normal

Figura 9.25 - Compósito com teor 15\%

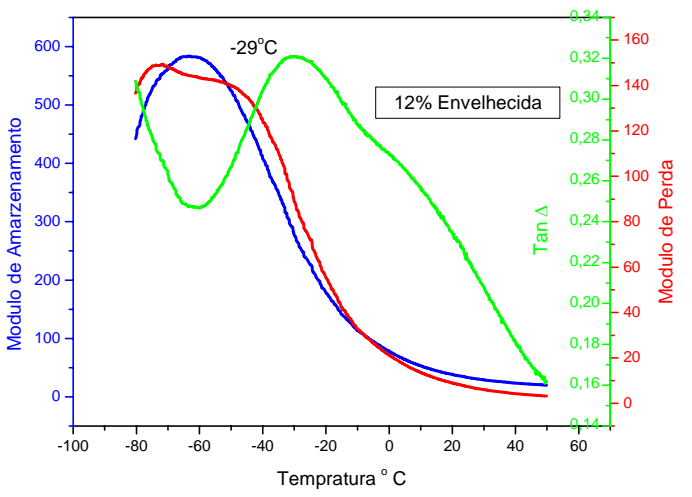

Figura 9.24 b - Compósito com teor $12 \%$ submetido ao intemperismo artificial

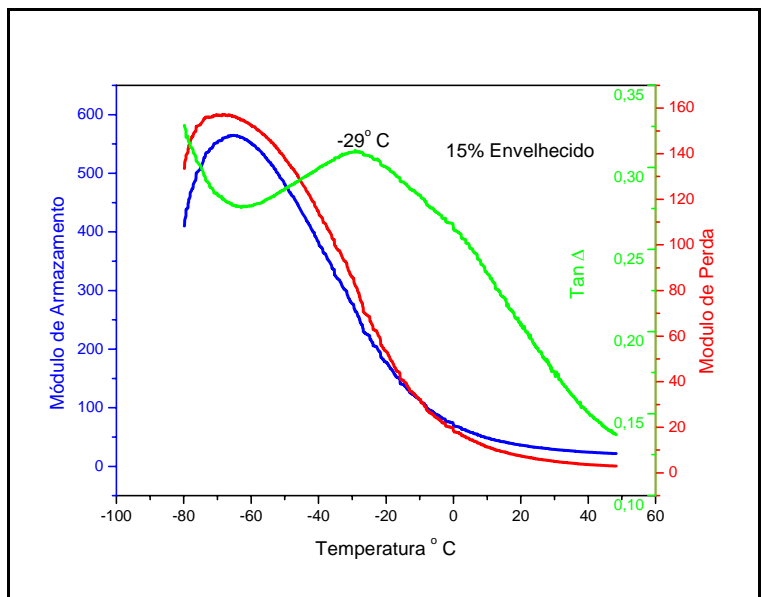

Figura 9.25 b - Compósito com teor $15 \%$ submetido ao intemperismo artificial 


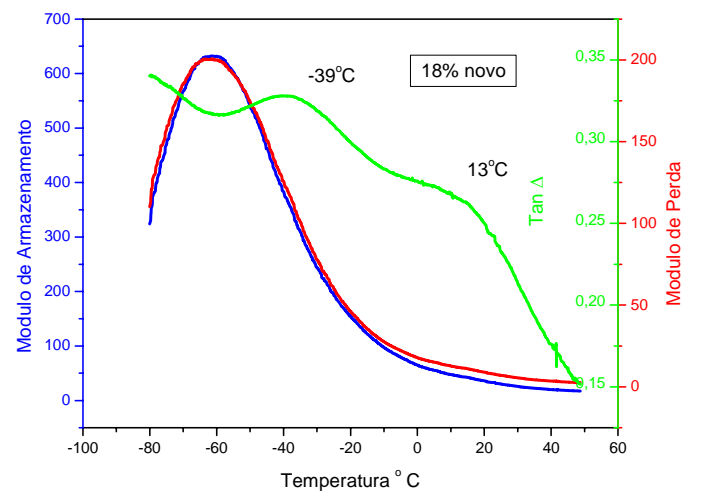

Figura 9.26 a - Compósito com teor $18 \%$ em ambiente normal

Figura 9.26 - Compósito com teor 18\%

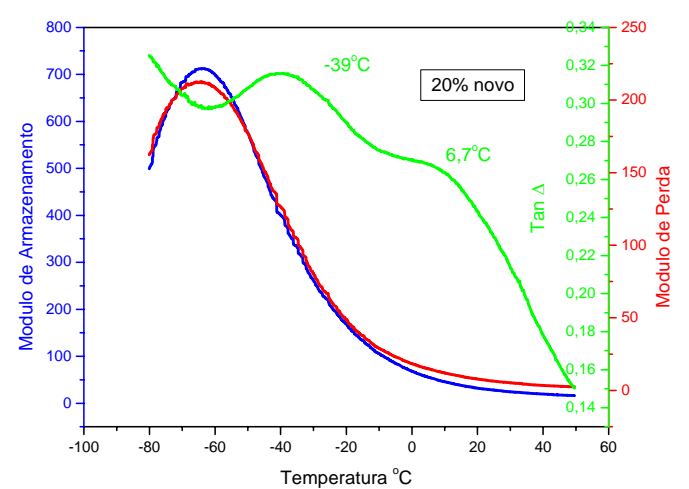

Figura 9.27 a - Compósito com teor $20 \%$ em ambiente normal

Figura 9.27 - Compósito com teor 20\%

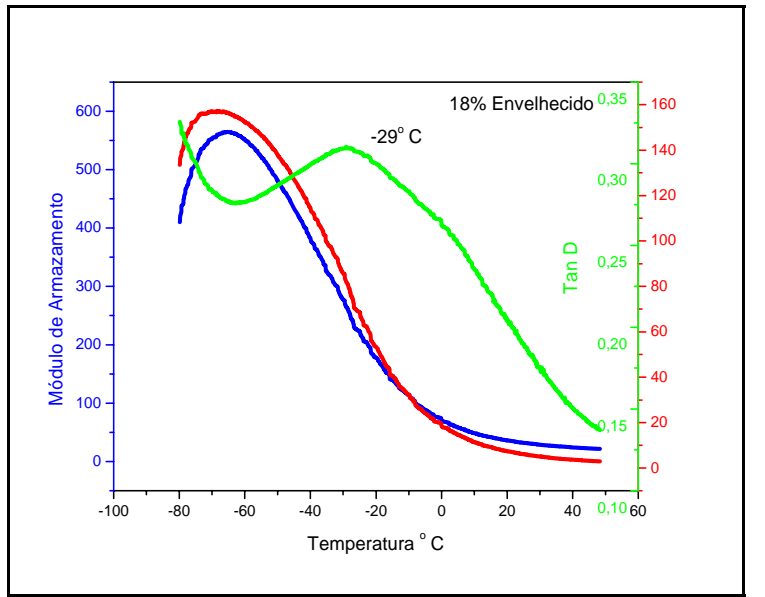

Figura 9.26 b - Compósito com teor $18 \%$ submetido ao intemperismo artificial

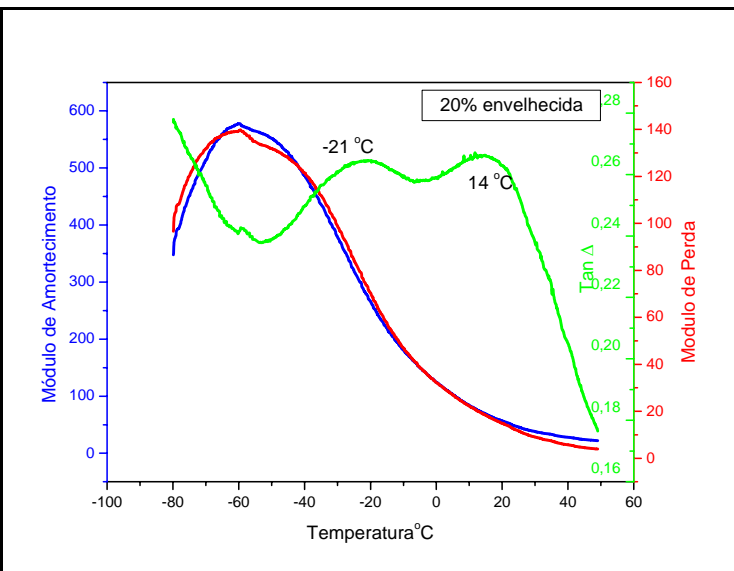

Figura 9.27 b - Compósito com teor $20 \%$ submetido ao intemperismo artificial

Tabela 9.23 - Valores de transição vítrea dos compósitos antes e depois de serem sujeitos a câmara de intemperismo

\begin{tabular}{ccccccc}
\hline Amostra & Tan $\delta$ & E'(MPa) & E'(MPa) & $\begin{array}{c}\text { Envelhecida } \\
\text { Tan } \delta\end{array}$ & E'(MPa) & E’(MPa) \\
\hline $12 \%$ & -37 & 410,6 & 146,1 & -29 & 265,4 & 85,10 \\
$15 \%$ & -37 & 424,6 & 147,4 & -29 & 270,1 & 79,85 \\
$18 \%$ & -39 & 370,2 & 121,4 & -29 & 264,2 & 81,89 \\
$20 \%$ & -39 & 392,8 & 124,1 & -21 & 277,1 & 73,29 \\
\hline
\end{tabular}




\begin{tabular}{ccccccc}
\hline $\begin{array}{c}\text { Amostras } \\
\mathbf{2 5}^{\mathbf{}} \mathbf{C}\end{array}$ & $\begin{array}{c}\text { E'(MPa) } \\
\text { Novo }\end{array}$ & $\begin{array}{c}\text { E'(MPa) } \\
\text { Novo }\end{array}$ & $\begin{array}{c}\text { E'(MPa) } \\
\text { env }\end{array}$ & $\begin{array}{c}\text { E”(MPa) } \\
\text { env }\end{array}$ & \% E' & \% E' \\
\hline $12 \%$ & 25,76 & 5,584 & 33,14 & 7,33 & 28,65 & 31,3 \\
$15 \%$ & 30,07 & 6,646 & 32,08 & 6,05 & 6,68 & 8,97 \\
$18 \%$ & 30,13 & 7,009 & 32,18 & 6,11 & 6,8 & 12,8 \\
$20 \%$ & 28,02 & 6,43 & 46,01 & 11,65 & 64,2 & 81,2 \\
\hline
\end{tabular}

O aumento da temperatura de transição vítrea ocorrida nos compósitos após o envelhecimento sob a radiação UV significa um decréscimo na elasticidade do polímero. Almeida e Ferreira (2006) também constataram um aumento da temperatura de transição vítrea com a resina poliuretana de origem vegetal após ser submetida à ação de raios UV.

Os compósitos com maior teor de resina PU tendem a sofrer um incremento no valor de Tan $\delta$, em decorrência da resina ser mais susceptível à ação do intemperismo.

\subsubsection{Fluência - CREEP (Curvas Master)}

Fluência é definida como a deformação permanente, dependente do tempo e da temperatura, quando o material é submetido à uma carga constante.

Este fator muitas vezes limita o tempo de vida de um determinado componente ou estrutura. Os fatores que afetam a fluência são a temperatura, modulo de elasticidade e tamanho dos grãos.

O comportamento mecânico ou dinâmico-mecânico de materiais poliméricos, os quais não obedecem somente à Lei de Hooke e também não se enquadram somente na Lei de Newton, por apresentarem comportamento mecânico intermediário ao elástico e ao viscoso, é chamado de viscoelástico. 
Para ensaios de fluência (creep) esses materiais apresentam uma variação em sua viscoelasticidade em função do tempo. Essa curva é expressa em função do log $(\text { compliance })^{11}$ por log do tempo.

Sujeitando o material a ser analisado por meio do ensaio de DMA, a diferentes temperaturas, se consegue determinar mediante curvas iniciais para cada temperatura, a curva Máster com esta determina-se a previsão da vida útil deste material em função do decaimento do módulo de elasticidade.

O compósito em estudo foi comparado com o neoprene visando estabelecimento de relação de uso para sua utilização em aparelho de apoio

Comparando com o neoprene observa-se que o compósito apresenta ao longo do tempo um decréscimo do módulo de elasticidade. Também foi observado que o módulo de elasticidade do neoprene é menor que o módulo do compósito em estudo.

Nos itens a, b, c, d e e da Figura 9.28 estão apresentadas as curvas máster do neoprene utilizado como referência, e dos compósitos com teores de resina de $12 \%, 15 \%, 18 \%$ e $20 \%$, respectivamente.

\footnotetext{
${ }^{11} \mathrm{O}$ inverso da Compliance corresponde ao módulo de elasticidade longitudinal (E).
} 


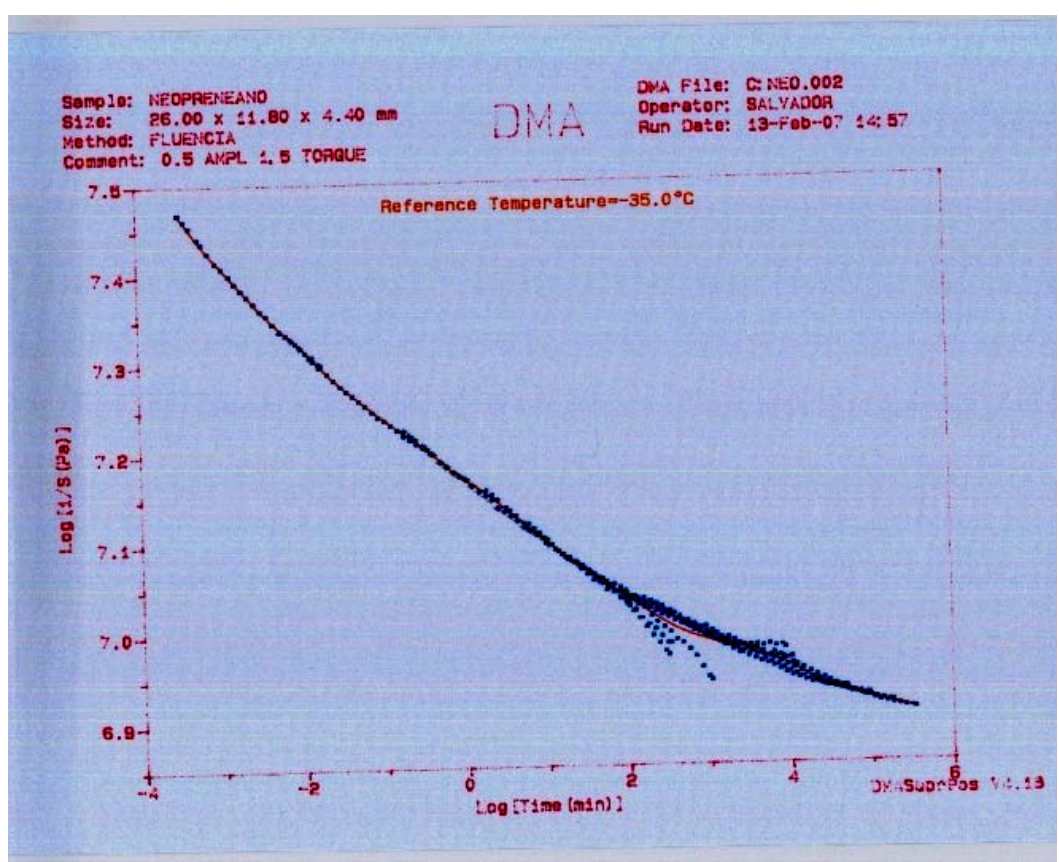

a) Neoprene

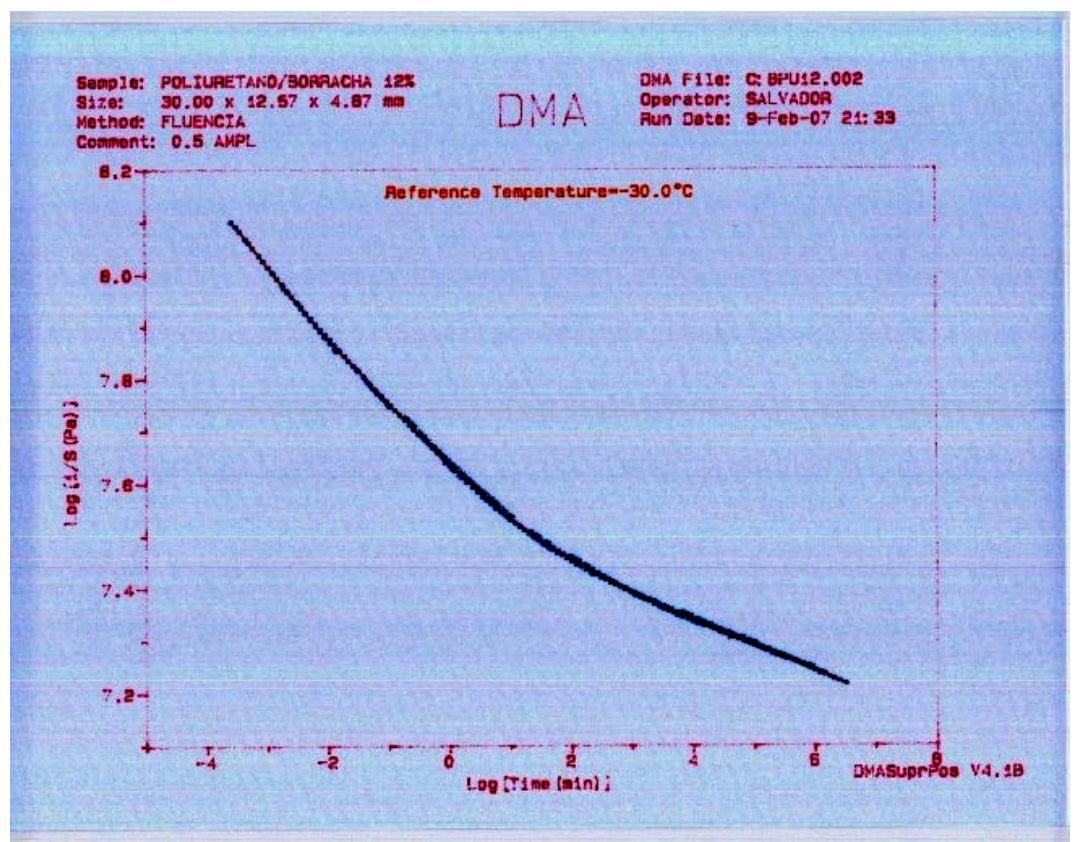

b) Compósito com $12 \%$ 


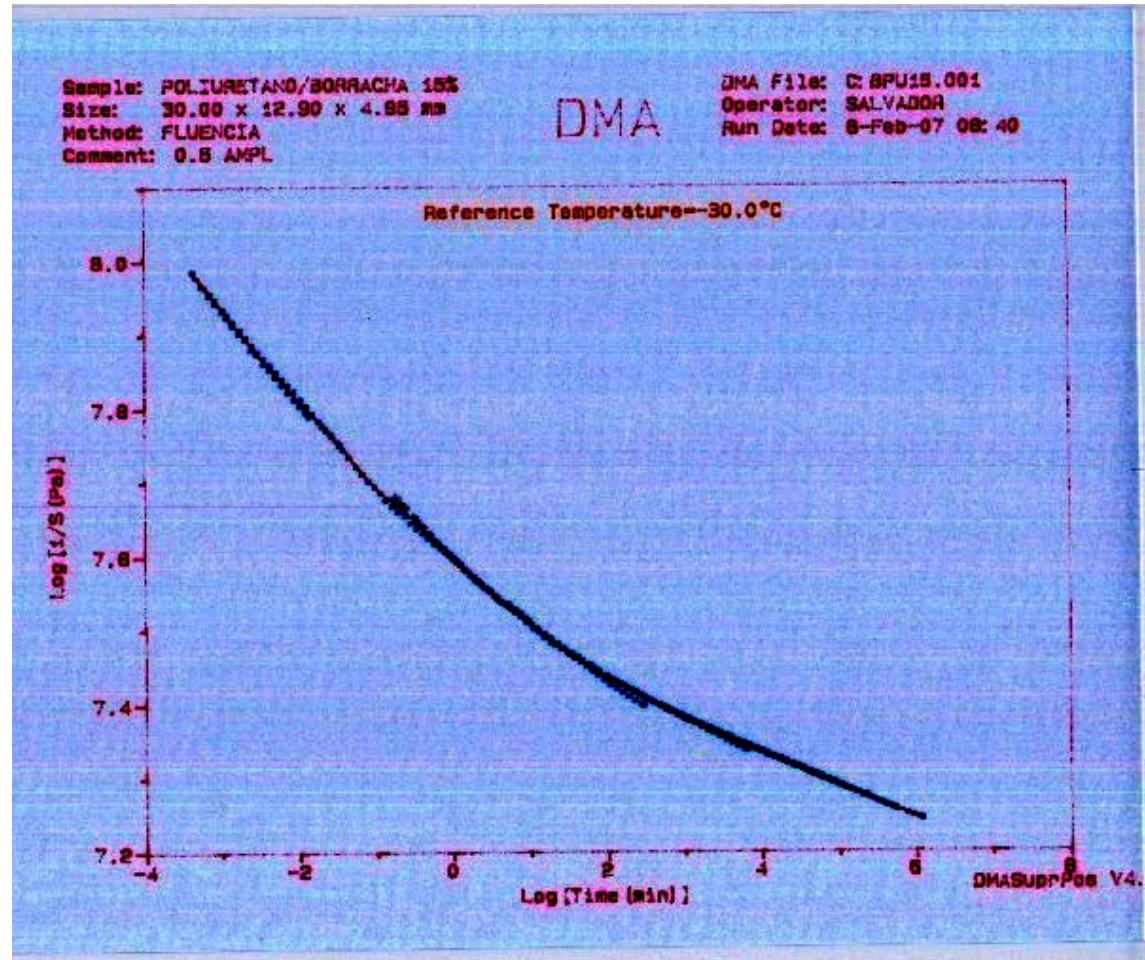

c) Compósito com $15 \%$

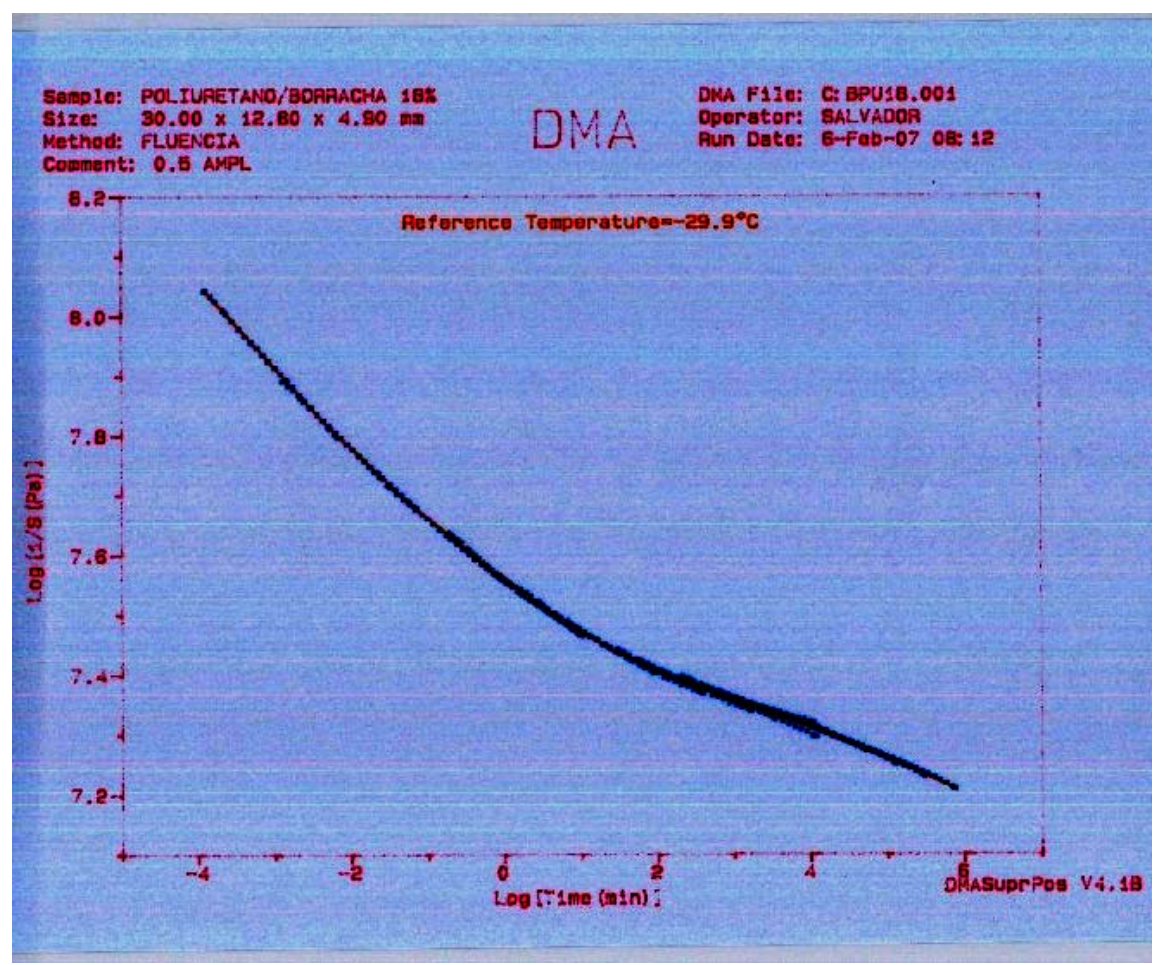

d) Compósito com $18 \%$ 


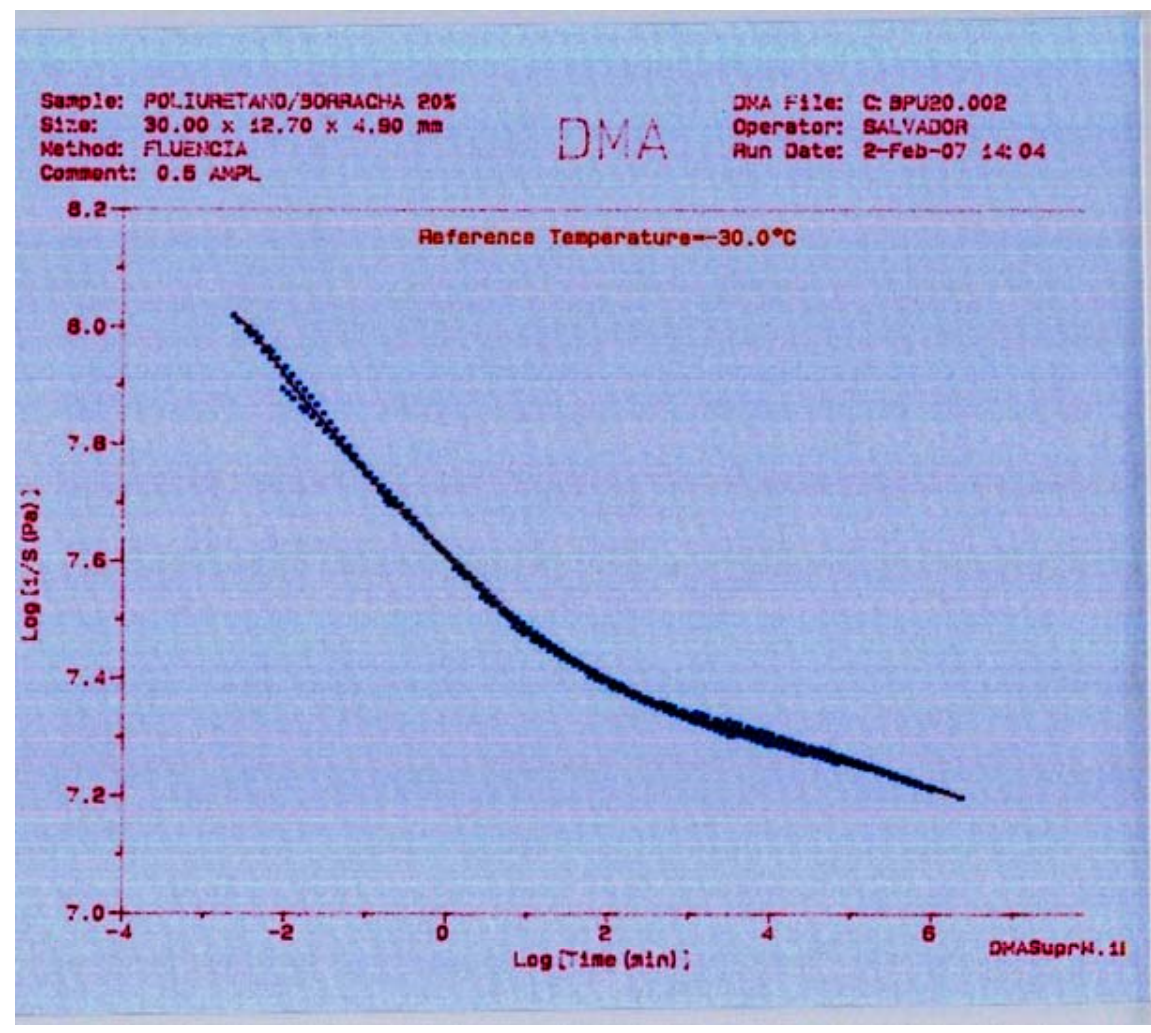

e) Compósito com $20 \%$

Figura 9.28 - Curvas Master do Neoprene e dos compósitos

Tabela 9.24 - Parâmetros retirados das curvas constantes da Figura 9.28.

\begin{tabular}{ccccc}
\hline Material & $\log (\mathbf{t}) \mathbf{m i n}$ & $\log (\mathbf{E}) \mathbf{P a}$ & $\mathbf{E}(\mathbf{M P a})$ & $\begin{array}{c}\text { Decaimento } \\
(\mathbf{\%})\end{array}$ \\
\hline \multirow{2}{*}{ Neoprene } & -2 & 7,33 & 21,38 & \\
& 0 & 7,19 & 15,49 & \\
& 2 & 7,05 & 11,22 & $\mathbf{2 7 , 5 7}$ \\
\hline $12 \%$ & -2 & 7,85 & 70,79 & \\
& 0 & 7,61 & 40,74 & $\mathbf{3 0 , 8 3}$ \\
\hline $15 \%$ & 2 & 7,45 & 28,18 & \\
& -2 & 7,8 & 63,09 & $\mathbf{2 7 , 5 6}$ \\
\hline $18 \%$ & 0 & 7,59 & 38,90 & \\
& 2 & 7,45 & 28,18 & $\mathbf{2 7 , 5 6}$ \\
\hline $20 \%$ & -2 & 7,79 & 61,66 & \\
& 0 & 7,59 & 38,90 & $\mathbf{3 5 , 4 4}$ \\
\hline
\end{tabular}


$\mathrm{Na}$ Tabela 9.25 tem-se os valores do decaimento do módulo de Elasticidade dos materiais, de onde se conclui que o comportamento do compósito a base de borracha e resina PU apresenta semelhança com o neoprene utilizado como referência, quando os teores de resina são de $15 \%$ e $18 \%$.

\subsubsection{Equação de Arrhenius}

A equação de Arrhenius fornece a relação entre energia de ativação e a velocidade de reação química entre duas substâncias e pode, por analogia, pode ser considerada para a compreensão dos fenômenos que ocorrem na região de transição vítrea de polímeros amorfos, os quais variam de um comportamento típico de material rígido para o de material elastomérico, com a variação da temperatura.

Quanto maior a temperatura mais facilmente a reação será capaz de ultrapassar a energia de ativação. Para que ocorra a reação e ultrapasse a energia de ativação, a temperatura, orientação e energia das moléculas devem ser substanciais; e esta equação controla a soma de todos estes parametros.

Resumidamente, aumentando-se a temperatura vai-se aumentar a velocidade da relaxaçãodo polímero, resultante dos movimentos da cadeia polimérica e que irá depender de fatores como a composição do polímero, do seu grau de reticulação e de cristalinidade.

Nos compósitos desenvolvidos a borracha não pode ser considerada como carga, pois está presente numa quantidade que varia de $80 \%$ a $88 \%$ em relação à resina poliuretana, fazendo com que a resina tenha uma mínima interferência sobre o comportamento dinâmicomecânico típico de polímeros amorfos e semicristalinos em função da temperatura.

Os intens a, b, c, d, e e constantes da Figura 9.29 expressam graficamente, para Neoprene e compósito borracha e resina PU nos diferentes teores, a equação de Arrhenius. 


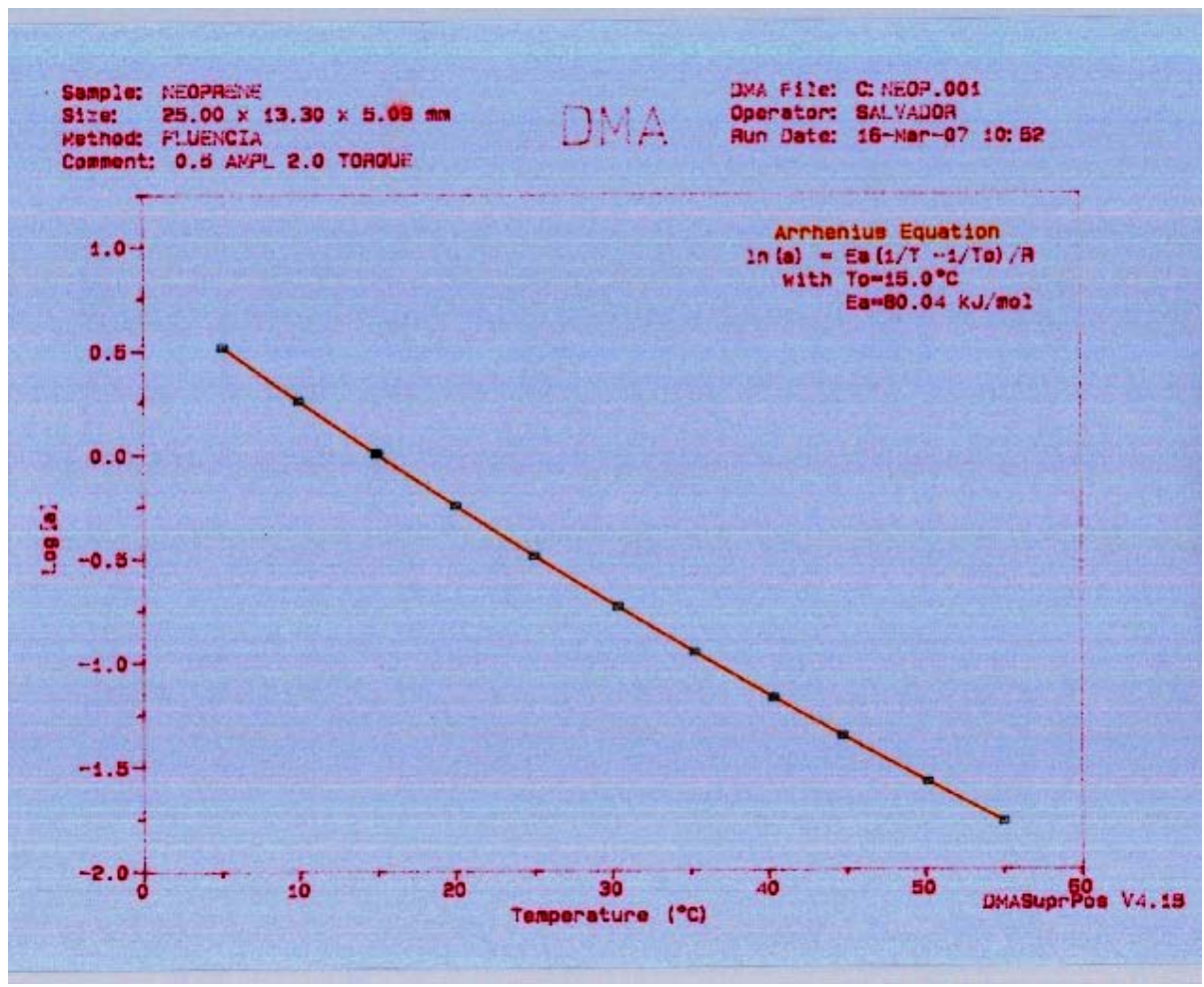

a) Neoprene

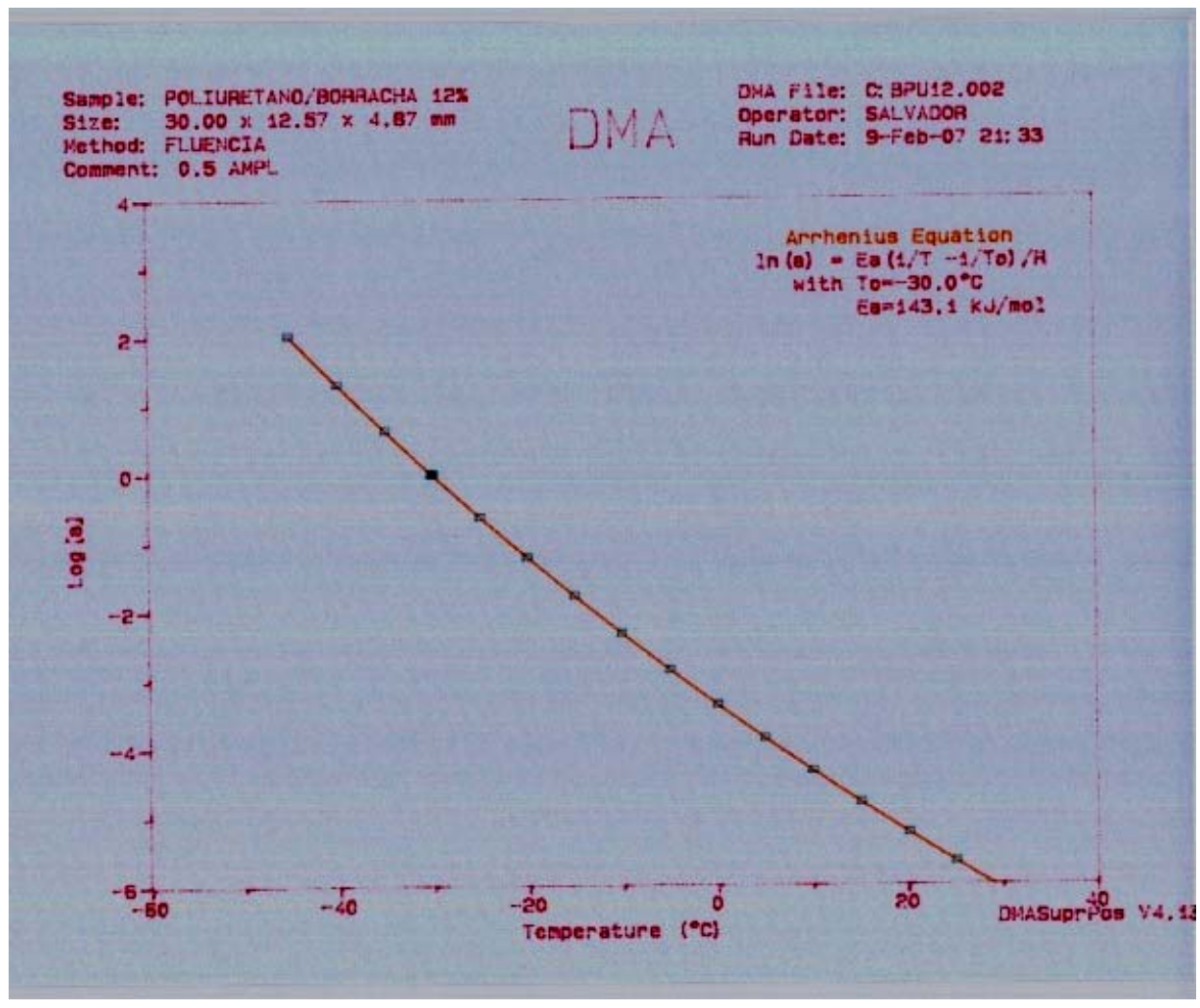

b) Compósito com $12 \%$ 


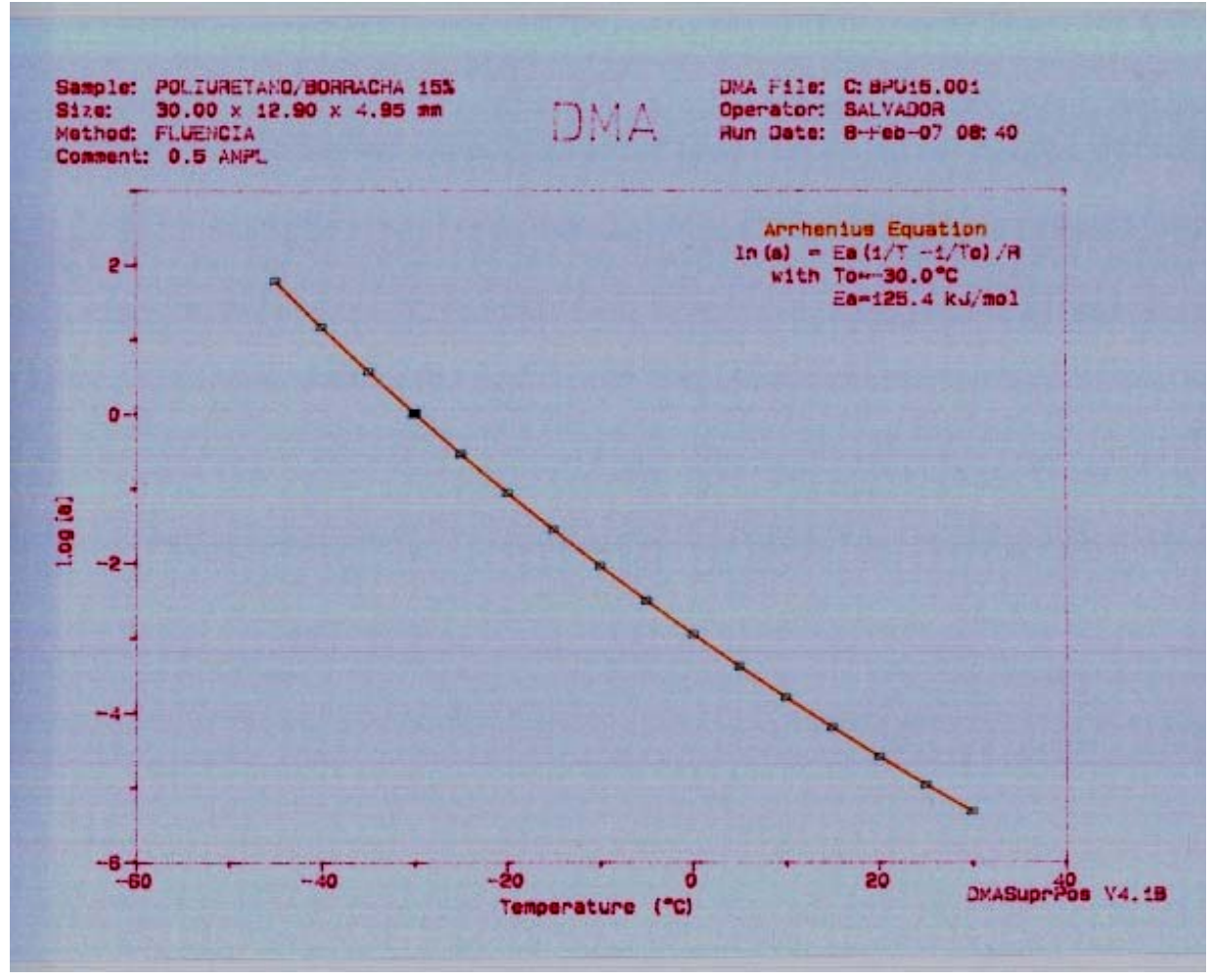

c) Compósito com $15 \%$

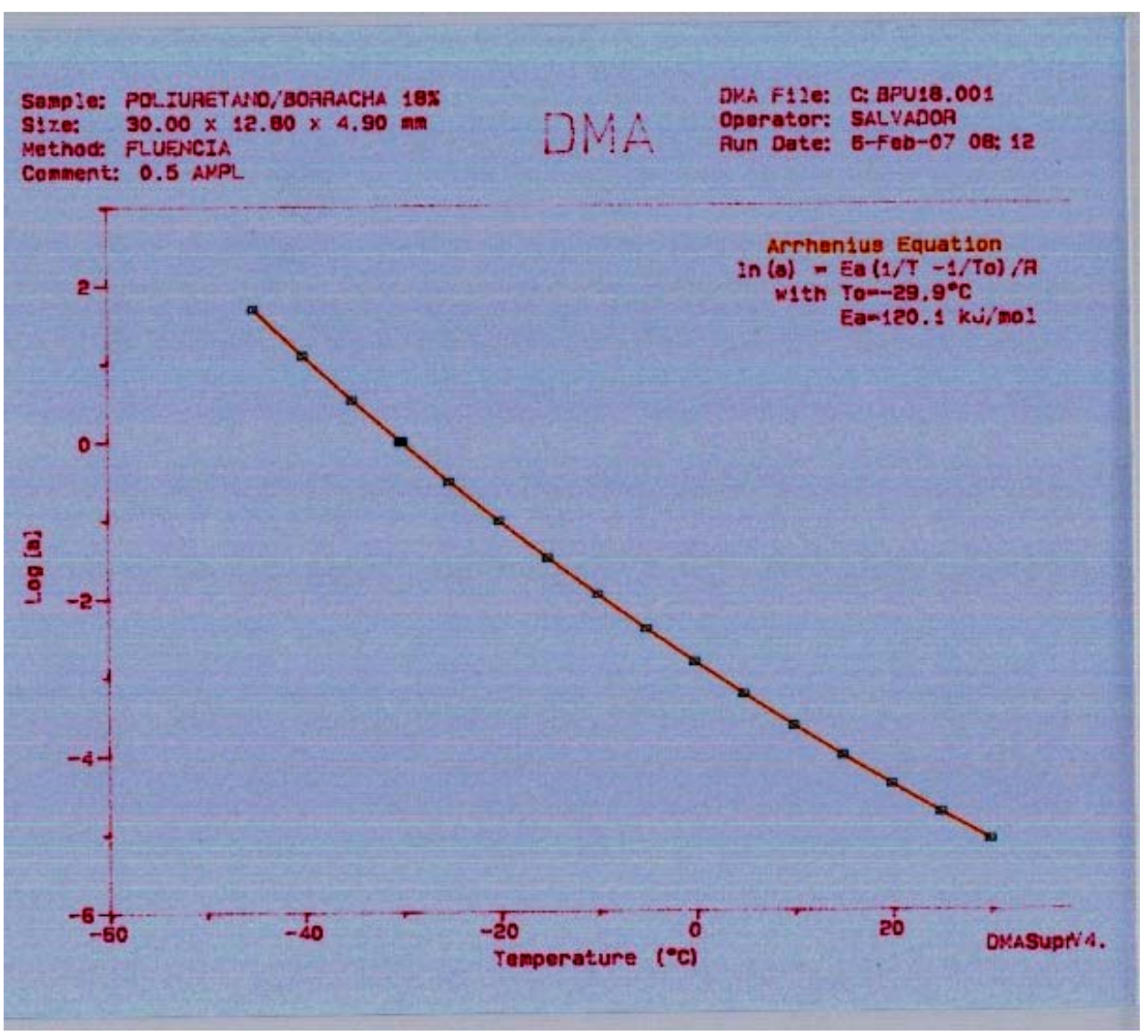

d) Compósito com 18\% 


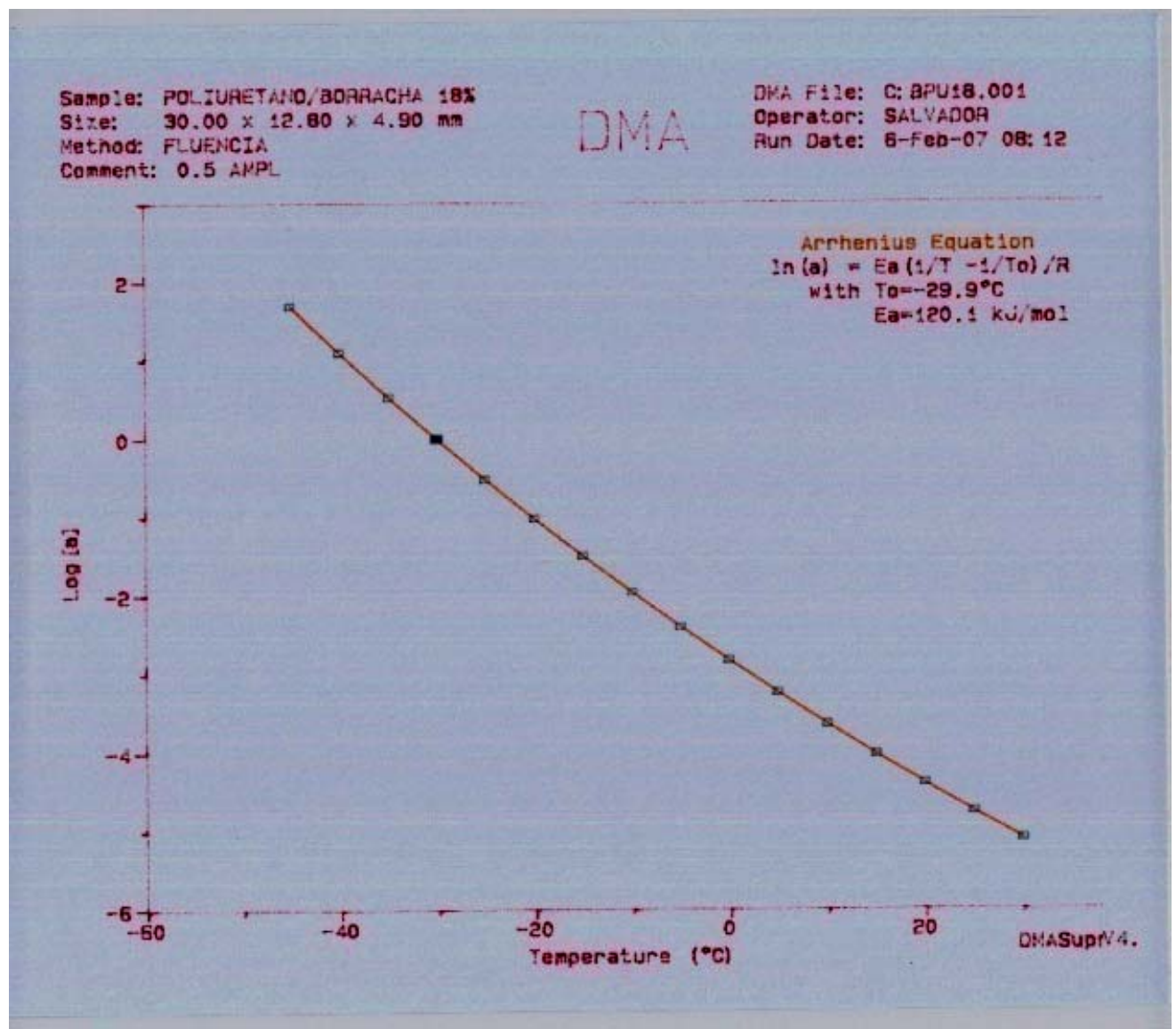

e) Compósito com $20 \%$

Figura 9.29 - Valores gráficos obtidos no ensaio DMA por meio da equação de Arrhenius

Tabela 9.25 - Valores da Energia de Ativação para os compósitos e o Neoprene utilizado como referência com base na equação de Arrhenius

\begin{tabular}{lcc}
\hline Material & Ea (kJ/mol) & To $\left({ }^{\mathbf{0}} \mathbf{C}\right)$ \\
\hline Neoprene & 80,04 & 15 \\
PU 12\% & 143,1 & -30 \\
PU 15\% & 125,4 & -30 \\
PU 18\% & 120,1 & $-29,9$ \\
PU 20\% & 120,1 & $-29,9$ \\
\hline
\end{tabular}

Analisando-se a Tabela 9.25 verifica-se que a energia de ativação para todos os compósitos analisados, é maior que a energia de ativação do Neoprene. Isto significa que se necessita de maior quantidade de energia de ativação envolvente para os compósitos de borracha e resina PU. 


\subsubsection{Equação de Williams-Landel-Ferry (WLF)}

A equação WLF correlaciona às propriedades de viscosidade dos materiais amorfos, analisando as constantes $\mathrm{C} 1$ e $\mathrm{C} 2$.

Os valores de $\mathrm{C} 1$ e $\mathrm{C} 2$ estão relacionados ao volume livre fracional na $\mathrm{Tg}$ e ao coeficiente de expansão térmica do volume livre. Quando TR for igual a Tg , C1 e C2, para polímeros amorfos, adquirem valores universais de 17,44 e 51,6 respectivamente

Para temperatura de referência igual ao Tg do compósito em estudo, as constantes $\mathrm{C} 1$ e C2 adquirem os valores constantes nos itens a, b, c, d e e da Figura 9.30, baseados na equação WLF.

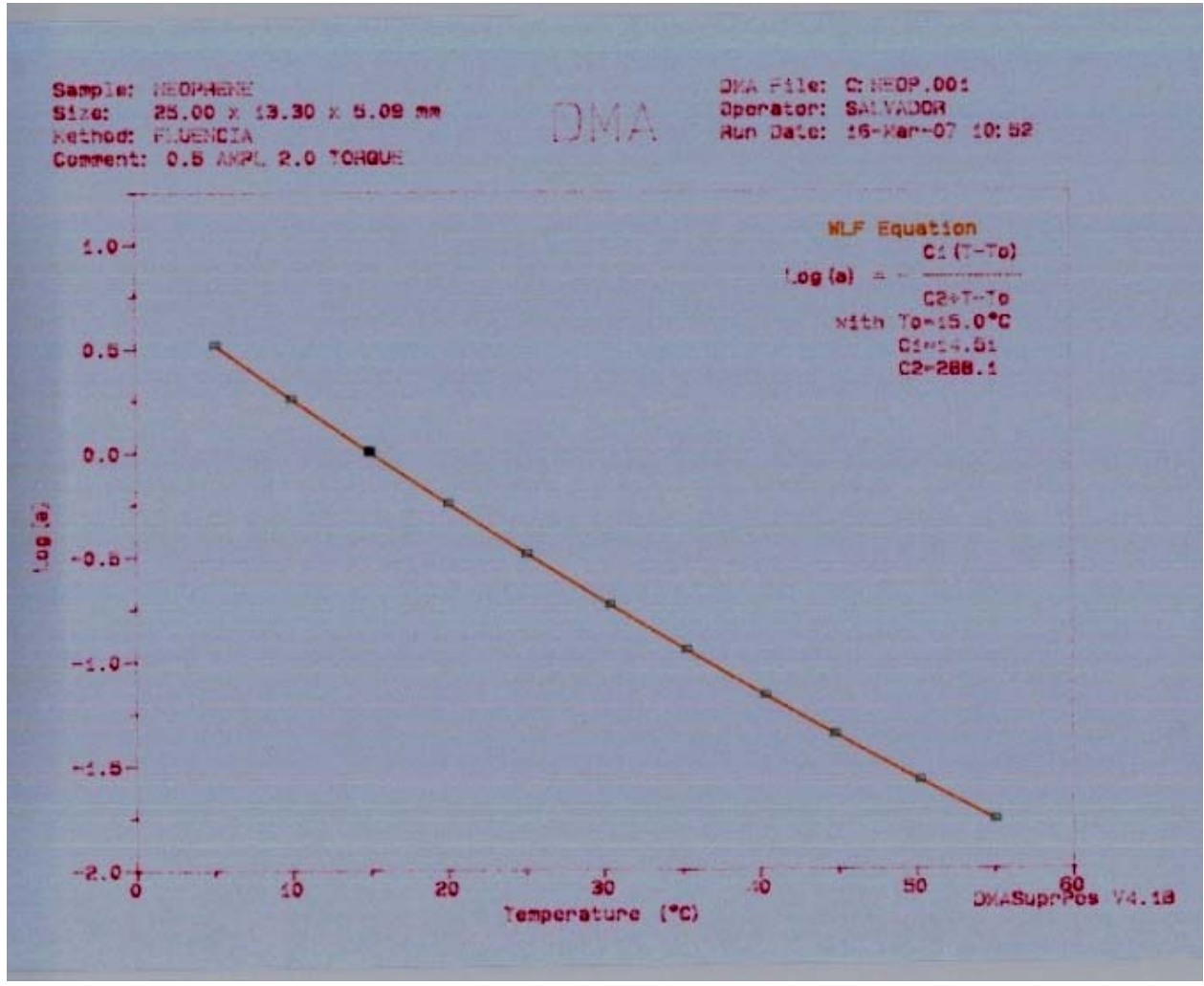

a) Neoprene 


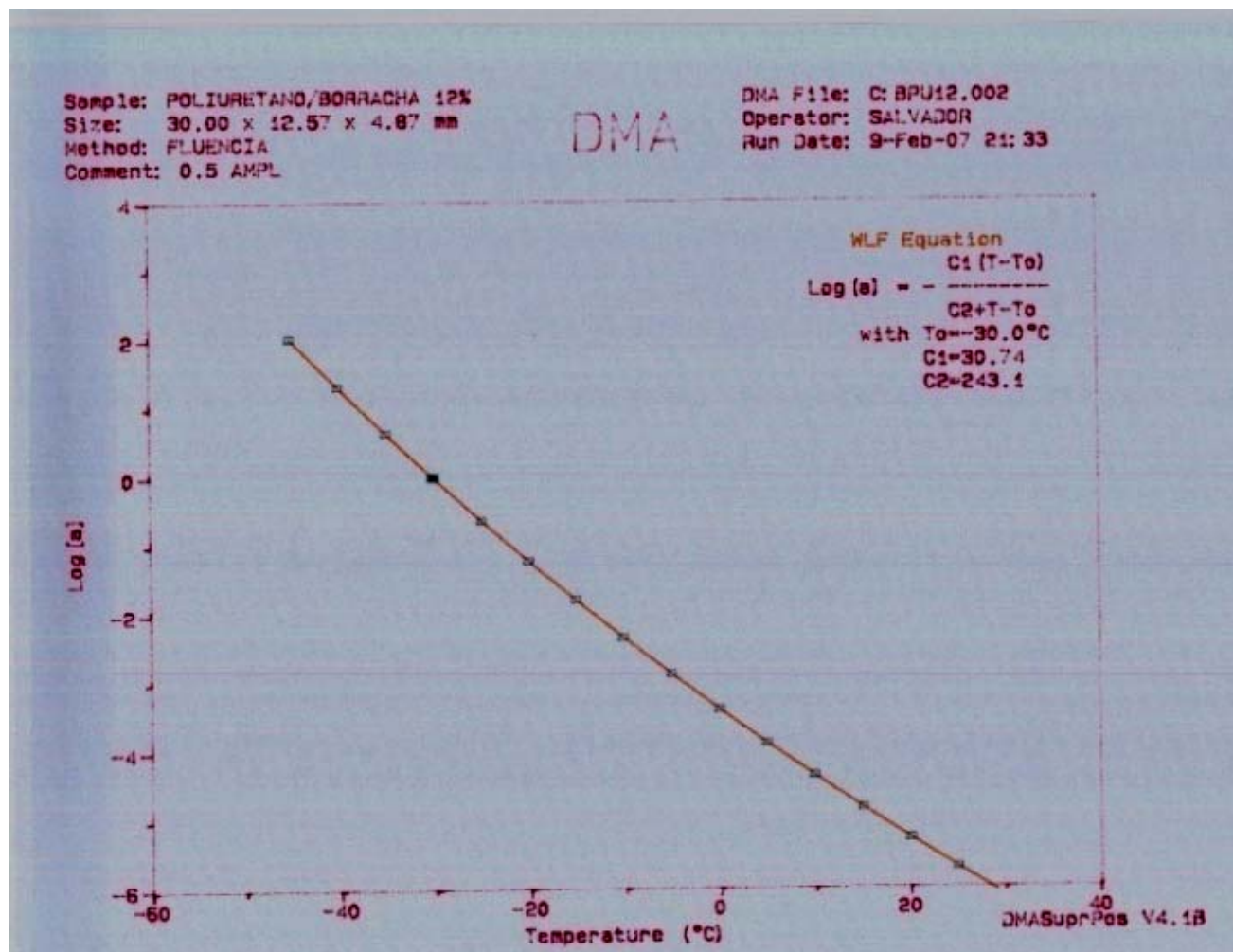

b) Compósito com $12 \%$

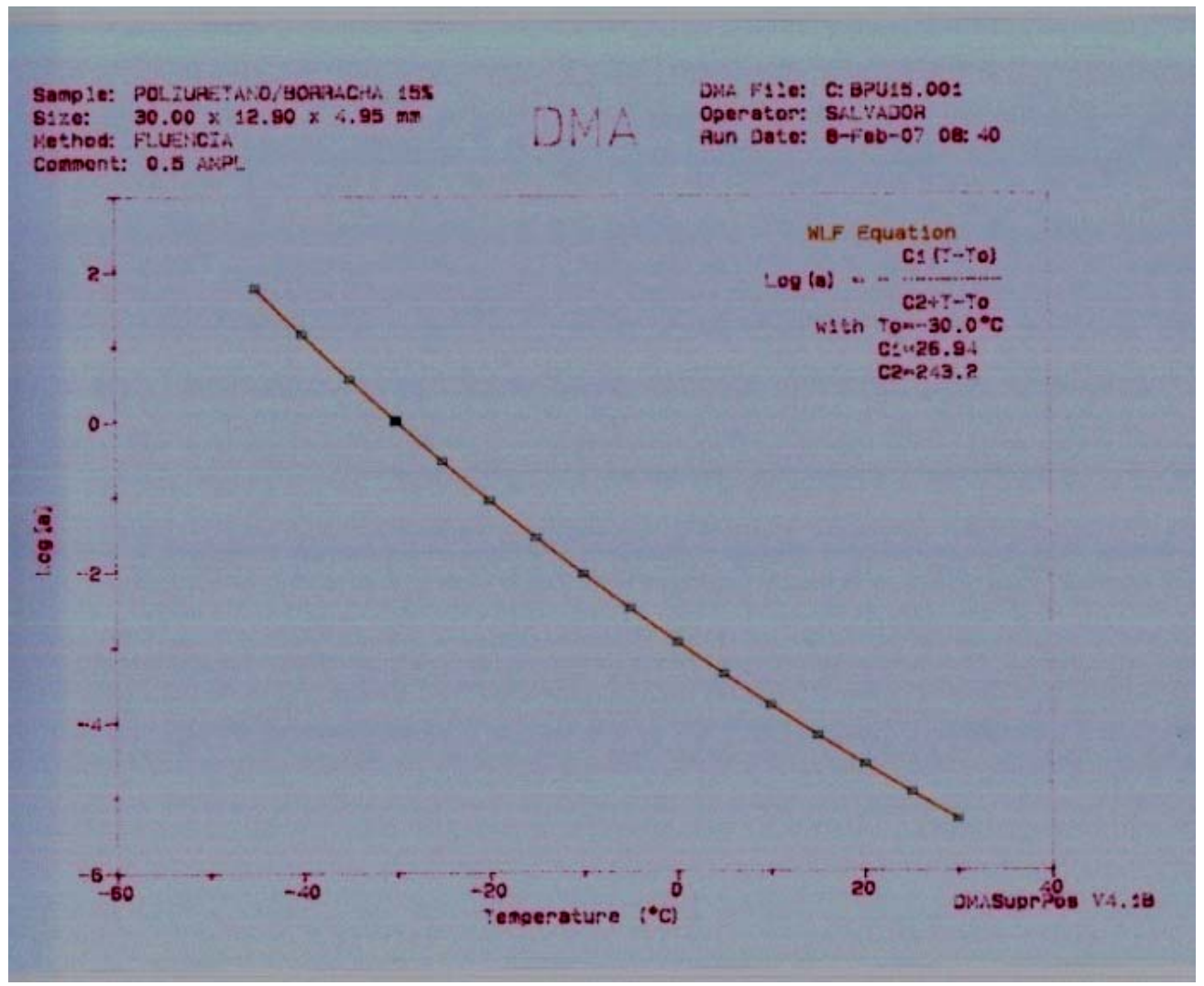

c) Compósito com $15 \%$ 


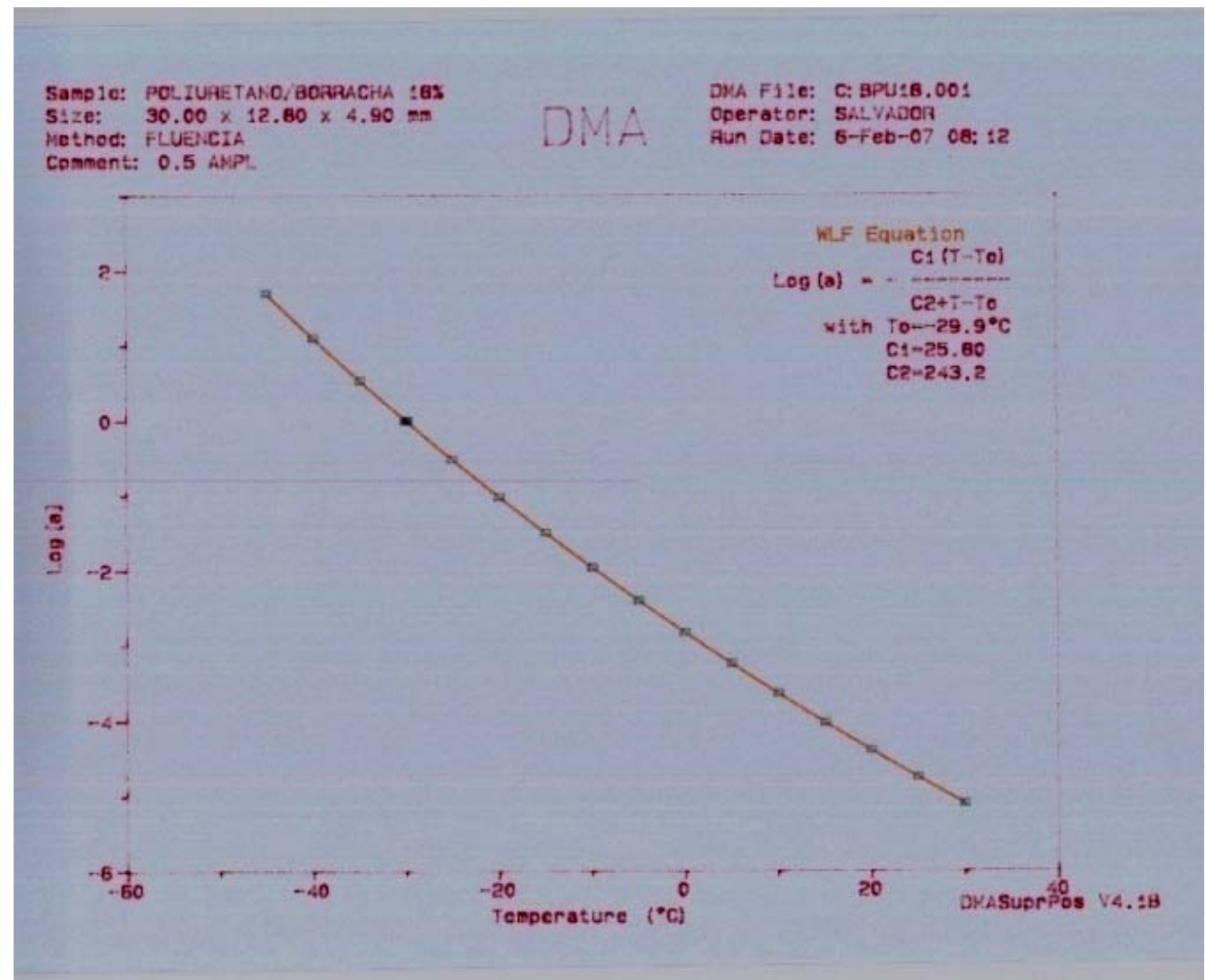

d) Compósito com 18\%

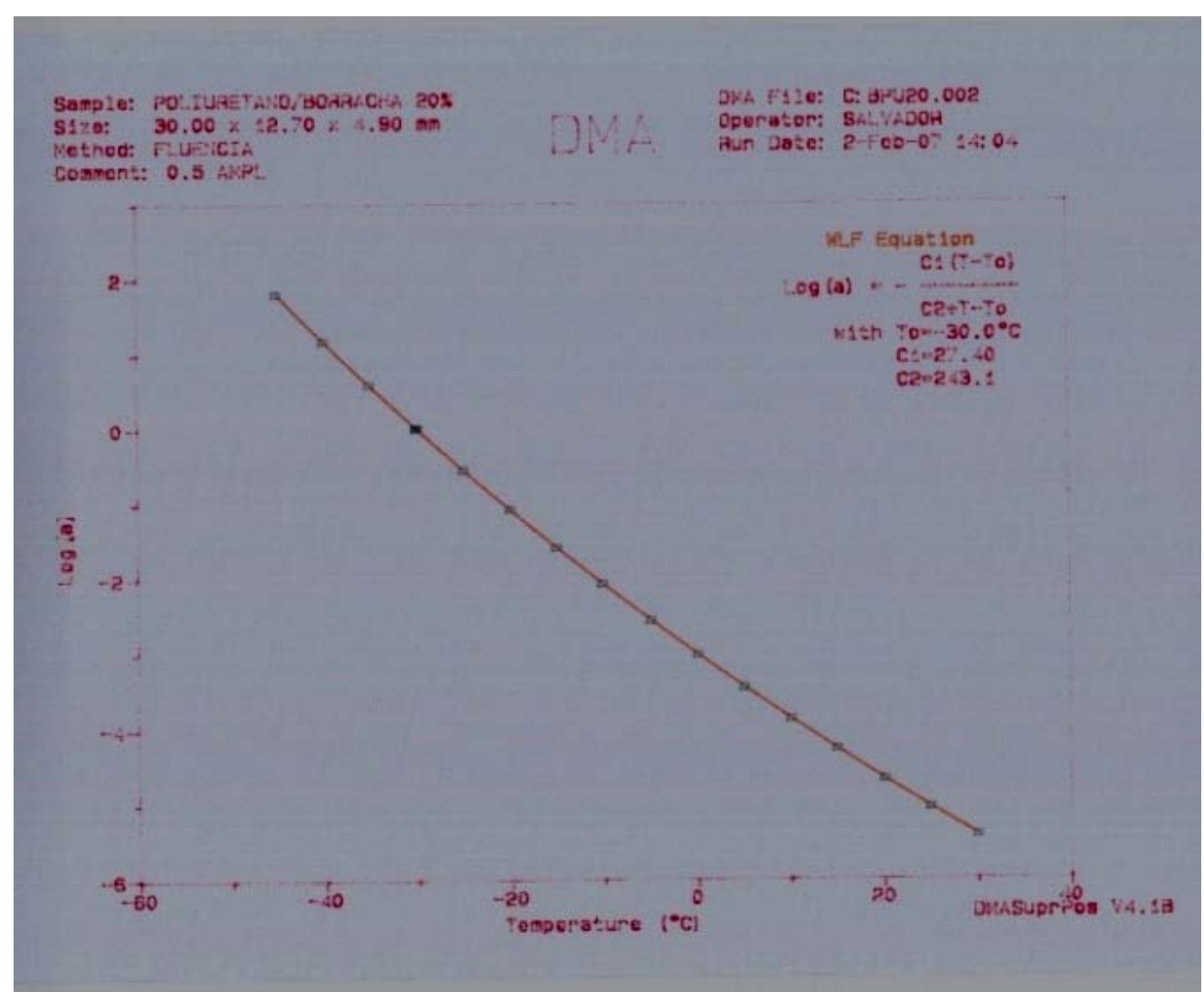

e) Compósito com $20 \%$

Figura 9.30 - Valores gráficos obtidos no ensaio DMA por meio da equação de WLF 
Tabela 9.26 - Valores de C1 e C2 obtidos para os diferentes compósitos e Neoprene

\begin{tabular}{lccc}
\hline Material & C1 & C2 & To $\left({ }^{\circ} \mathbf{C}\right)$ \\
\hline Neoprene & 14,51 & 288,1 & 15 \\
PU 12\% & 30,74 & 243,1 & -30 \\
PU 15\% & 26,94 & 243,2 & -30 \\
PU 18\% & 25,8 & 243,2 & $-29,9$ \\
PU 20\% & 27,4 & 243,1 & -30 \\
\hline
\end{tabular}

Analisando os valores obtidos constata-se que tanto o neoprene quanto os compósitos em estudo não são perfeitamente Amorfos.

\subsection{Ensaio de Propriedades Térmicas}

Tabela 9.27 - Resultados obtidos com os ensaios de Propriedades Térmicas

\begin{tabular}{lcccc}
\hline Amostra & $\boldsymbol{\rho}\left(\mathbf{K g} / \mathbf{m}^{\mathbf{3}}\right)$ & $\lambda\left(\mathbf{W} / \mathbf{m}^{\mathbf{0}} \mathbf{K}\right)$ & $\mathbf{c}\left(\mathbf{J} / \mathbf{K g} \mathbf{g}^{\mathbf{0}}\right)$ & $\boldsymbol{\alpha}\left(\mathbf{m}^{\mathbf{2}} / \mathbf{s}\right)$ \\
\hline Borracha & 745,00 & 0,15 & $1.613,90$ & $1,27 \mathrm{E}-07$ \\
\hline
\end{tabular}

$\rho$-Densidade do material; $\lambda$ - Condutividade térmica; $\mathrm{c}-$ Calor específico; $\alpha$-Difusividade térmica

$\mathrm{Na}$ Tabela 9.28 estão os valores de outros materiais utilizados na construção civil como uma forma de comparação.

Tabela 9.28 - Valores de condutividade térmica de outros materiais

\begin{tabular}{lccc}
\hline Material & $\begin{array}{c}\boldsymbol{\rho} \text { Densidade } \\
\left(\mathbf{K g} / \mathbf{m}^{\mathbf{3}}\right)\end{array}$ & $\begin{array}{c}\boldsymbol{\lambda} \text { Condutividade } \\
\left(\mathbf{W} / \mathbf{m}^{\mathbf{0}} \mathbf{K}\right)\end{array}$ & $\begin{array}{c}\mathbf{c} \text { Calor específico } \\
\left(\mathbf{J} / \mathbf{K g}^{\mathbf{0}} \mathbf{K}\right)\end{array}$ \\
\hline Argamassa comum & $1200-2100$ & 1,15 & 1.000 \\
Tijolos e telhas de barro & $1000-1300$ & 0,70 & 920 \\
Concreto normal & $2200-2400$ & 1,75 & 1000 \\
Placa de gesso, gesso & $750-1000$ & 0,35 & 840 \\
acartonado & & & \\
\hline
\end{tabular}


Os resultados obtidos evidenciam a influência que a densidade do material exerce na propriedade de condutividade térmica, fato que não se verifica para as propriedades de difusividade térmica e calor específico.

O material analisado Tabela 9.28 apresenta comportamento isolante suficiente para aplicações gerais conforme foi considerado no capítulo 10 .

As situações analisadas referem-se aos corpos de prova com umidade correspondente à de equilíbrio com o ambiente, o que sugere uma situação com elevada aproximação da real encontrada em obras de construção civil.

Os valores de condutividade térmica obtidos com o composto localizam-se dentro de um patamar muito bom para materiais de construção, cujos valores correspondentes à condutividade térmica situam-se entre 0,02 e $2,00 \mathrm{~W} / \mathrm{m}^{0} \mathrm{~K}$ (Tabela 9.28). 


\section{UTILIZAÇÕES POTENCIAIS DO COMPÓSITO}

Neste capítulo estão apresentadas algumas das utilizações potenciais que este compósito pode oferecer ao mercado da construção civil. Buscou-se caracterizar o compósito para diversas utilizações e neste capítulo foi dada ênfase ao seu desempenho para a constituição de placas de revestimento de pisos, como núcleo de painel sanduíche e aparelho de apoio entre elementos estruturais.

Nos capítulos 8 e 9, o compósito teve caracterizadas suas propriedades de modo a abranger o maior numero possível de utilizações potenciais.

\subsection{Placas de Revestimento de Pisos}

O compósito produzido pode ter diversas formas de acordo com os possíveis moldes, conforme exemplo apresentado na figura 10.1. 

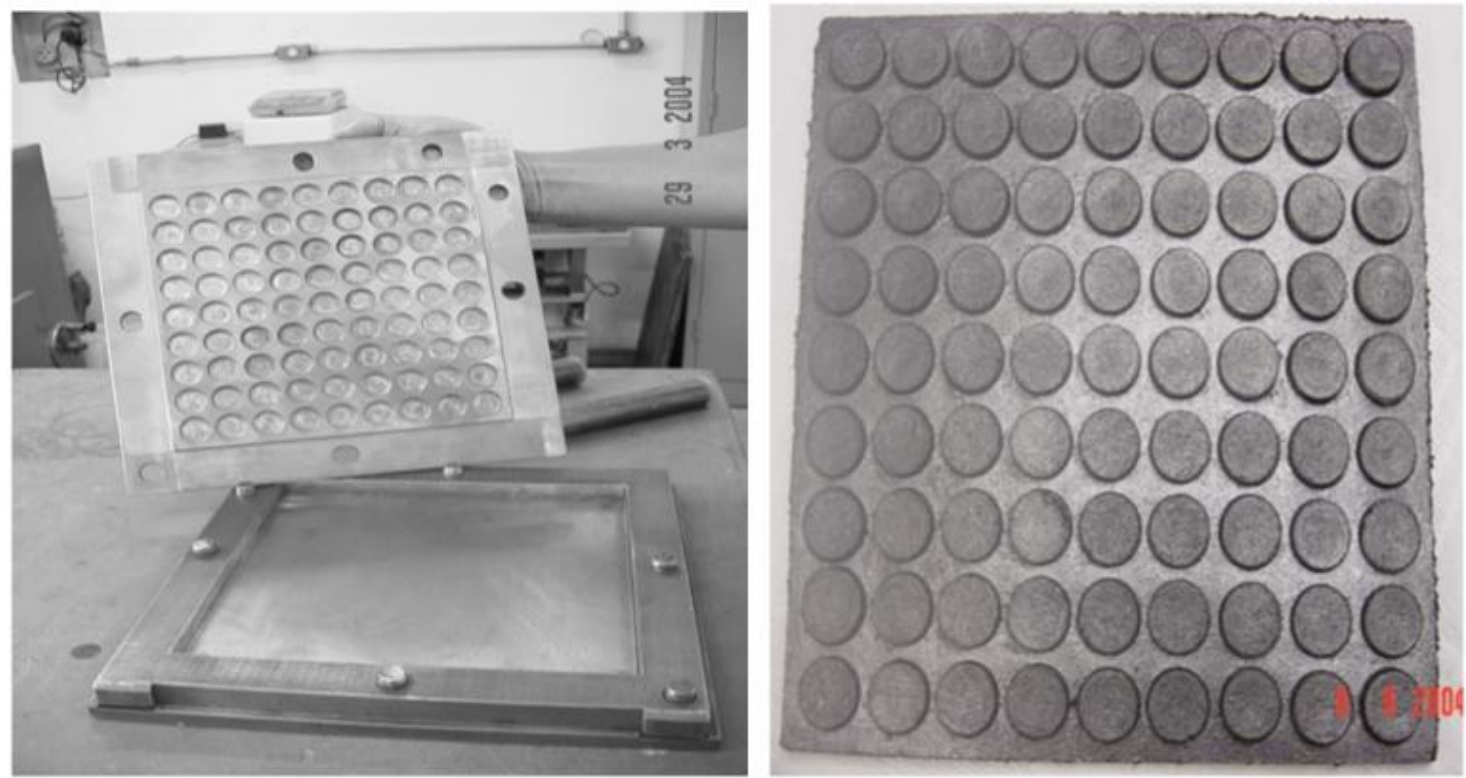

Figura 10.1 - Forma do revestimento e placa terminada

Conforme apresentado nos capítulos 8 e 9, os ensaios de desgaste por abrasão e resistividade elétrica permitem concluir sobre a viabilidade de uso do compósito como revestimento de pisos.

Os ensaios de abrasão foram realizados comparando o desempenho do compósito ao de um revestimento cerâmico de alta qualidade, obtendo-se um desgaste inferior ao do porcelanato utilizado como referência. Com relação à resistividade elétrica, o compósito apresentou desempenho satisfatório, pois hoje a tendência verificável no mercado é para a aplicação de pisos parcialmente isolantes e que apresentem boa absorção de energia mecânica sob condições de impacto.

\subsection{Painéis Sanduíche}

Um painel sanduíche compreende uma combinação de alternativas diferentes, de materiais simples ou compostos, reunidos e intimamente fixados um em relação ao outro, de modo a obter vantagens estruturais para o conjunto, maiores que as obtidas com as 
propriedades de cada material, isoladamente considerados. A Figura 10.2 apresenta um painel desenvolvido por Shultz (2005) com as faces exteriores em argamassa de cimento armadas com fibras de polipropileno de espessura $12 \mathrm{~mm}$, e a Figura 10.3 o núcleo composto por partículas de borracha e resina PU, com espessura aproximada de $25 \mathrm{~mm}$. Este compósito foi constituído com as partículas de borracha apresentando a mesma composição granulométrica e mesmo traço $1: 2$ (pré-polímero : poliol), diferindo com relação a sua densidade, que variou em 0,64 a $1,04 \mathrm{~g} / \mathrm{cm}^{3}$ com o propósito de possibilitar um maior grau de isolamento térmico do núcleo do painel. Portanto os ensaios relativos ao painel sanduíche estão apresentados neste capitulo para melhor compreensão.

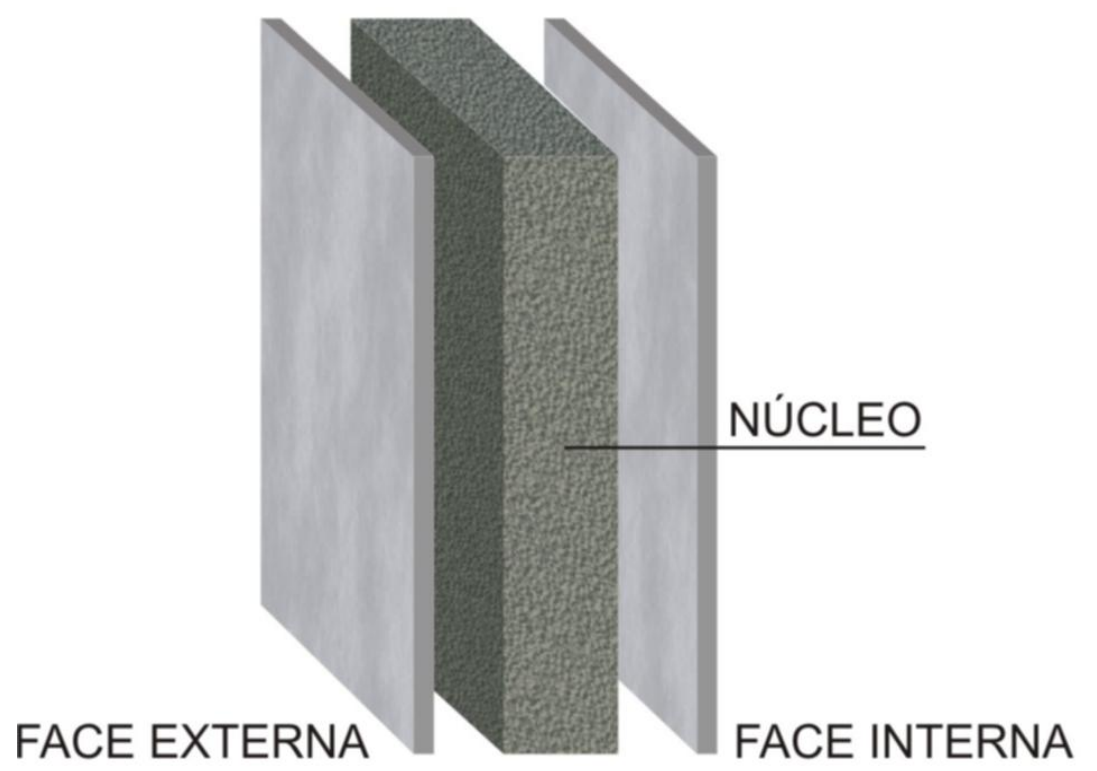

Figura 10.2 - Ilustração de painel sanduíche 


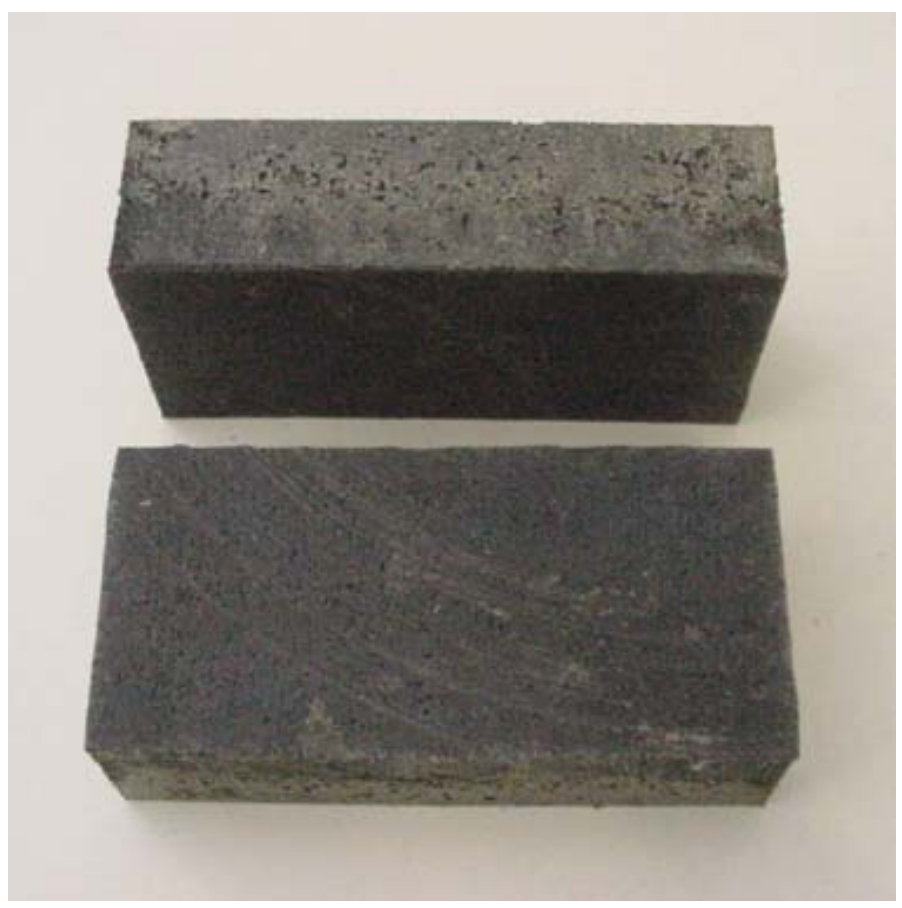

Figura 10.3 - Núcleo do painel compósito borracha/PU

Este painel alia dois importantes requisitos funcionais aos elementos de vedação, quais sejam:

- Sua condição autoportante, uma vez que no painel totalmente composto a seção transversal atua como se fosse uma seção única, de inércia majorada pelo afastamento das faces devido à presença do núcleo. Não existe deslocamento relativo entre as duas placas e ambas possuem função estrutural e resistem em conjunto aos esforços à que estão submetidas.

- Adequadas propriedades térmicas e acústicas.

Conforme os resultados apresentados no Capítulo 9 na Tabela 9.28 o material apresenta comportamento isolante adequado para compor o núcleo de painéis sanduíches, e os valores de condutividade térmica localizam-se dentro de um patamar muito bom para materiais de construção cujos valores correspondentes à condutividade térmica situam-se entre 0,02 e $2,00 \mathrm{~W} / \mathrm{m}^{\circ} \mathrm{K}$, conforme já mencionado. 


\subsubsection{Comportamento do Painel Sanduíche à Flexão}

O comportamento do painel sanduíche com núcleo de borracha e resina PU foi avaliado à flexão e na Figura 10.4 está um elemento sob ensaio.

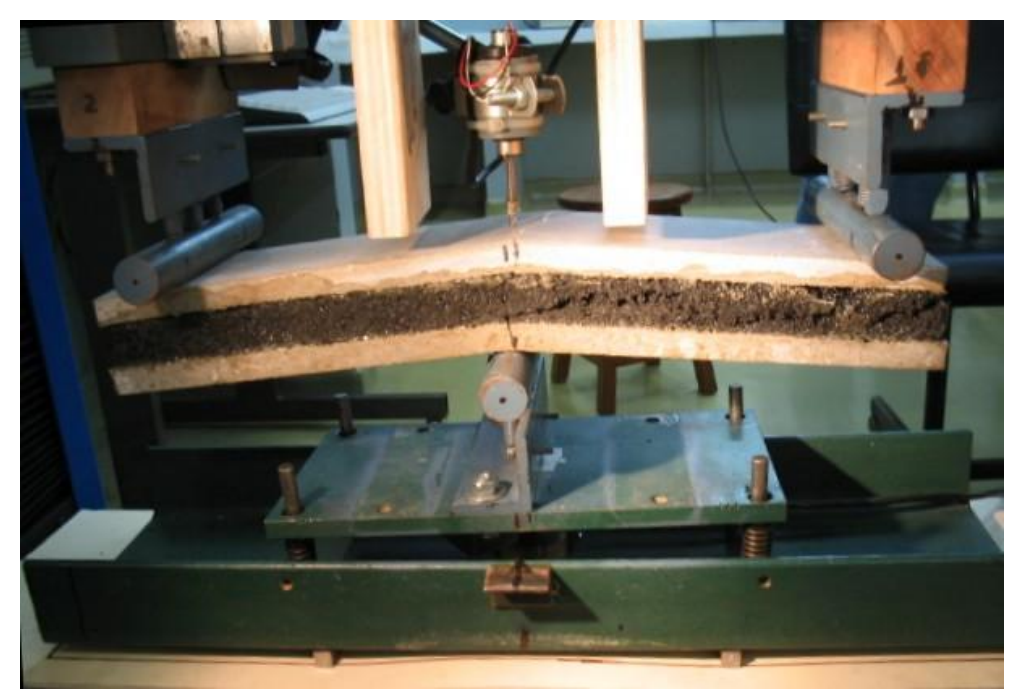

Figura 10.4 - Painel Sanduíche sob ensaio à Flexão.

Na Tabela 10.1 estão os resultados do teste de flexão dos elementos sanduíche.

Tabela 10.1 - Cargas máximas aplicadas no ensaio de flexão dos elementos sanduíche (N)

\begin{tabular}{ccccccc}
\hline AMOSTRAS & CP1 & CP2 & CP3 & CP4 & MÉDIA & FINAL \\
\hline $\begin{array}{c}\text { BORRACHA } \\
\text { D-01 }\end{array}$ & 731,5 & 784,5 & 790,0 & 576,2 & 720,5 & $\mathbf{7 6 8 , 7}$ \\
$\begin{array}{c}\text { BORRACHA } \\
\text { D-02 }\end{array}$ & 404,2 & 485,5 & 490,0 & 468,1 & 461,9 & $\mathbf{4 6 1 , 9}$ \\
$\begin{array}{c}\text { BORRACHA } \\
\text { D-03 }\end{array}$ & 547,0 & - & 521,2 & 484,5 & 517,5 & $\mathbf{5 1 7 , 5}$ \\
\hline
\end{tabular}

Observação: D-01, D-02 e D-03 correspondem às densidades do núcleo - alta, média e baixa, respectivamente. 
Na Figura 10.5 apresenta-se as curvas relativas aos elementos de média densidade $\left(0,84 \mathrm{~g} / \mathrm{cm}^{3}\right)$ submetidos ao ensaio de flexão. A densidade do núcleo interfere no comportamento a flexão.

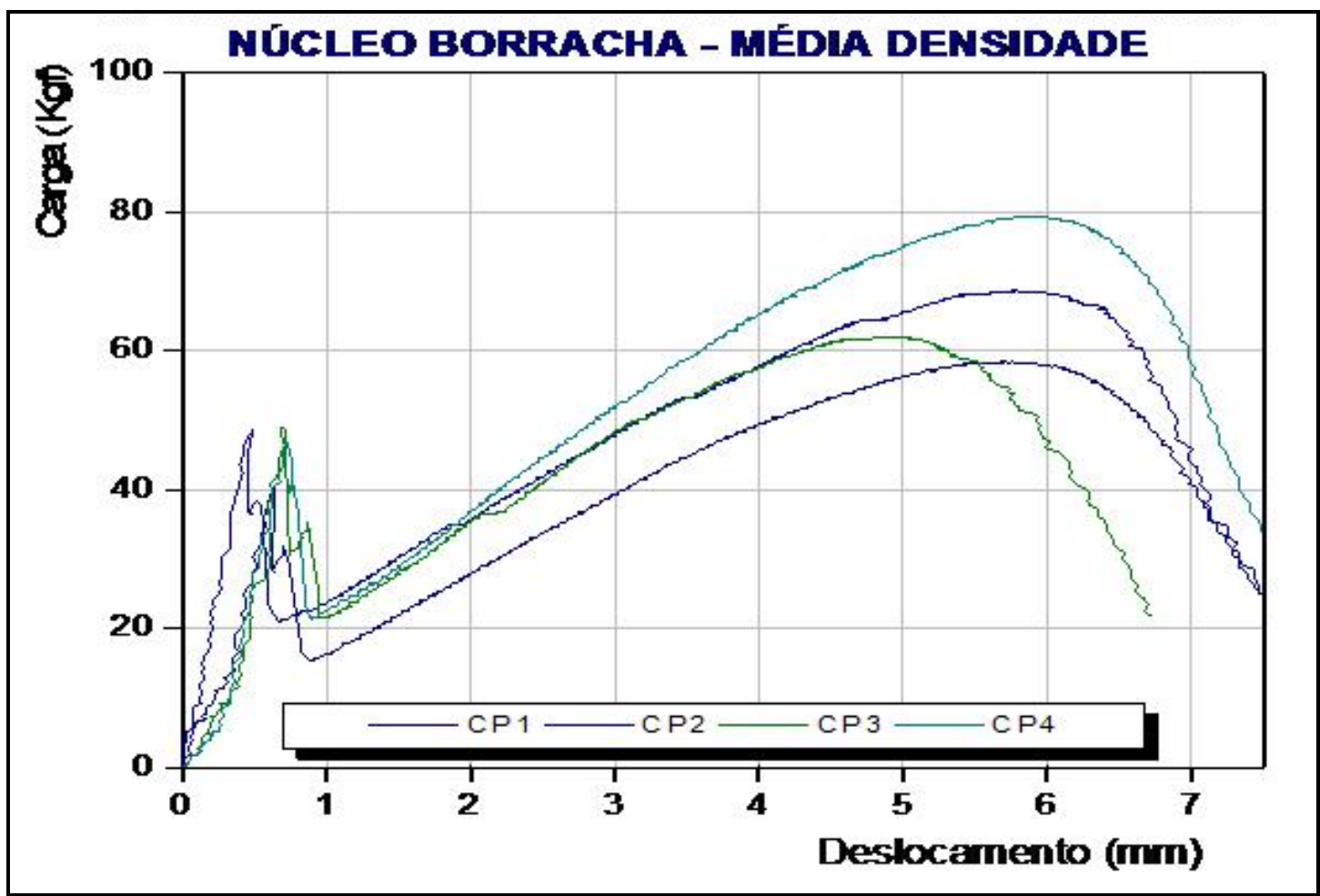

Figura 10.5 - Comportamento à flexão: Sanduíche com núcleo borracha D-02

Na Figura 10.6 apresenta-se as curvas médias relativas aos elementos com núcleos de diferentes densidades, submetidos ao ensaio de flexão. Pode verificar que os núcleos com maior densidade resistem a cargas mais altas. 


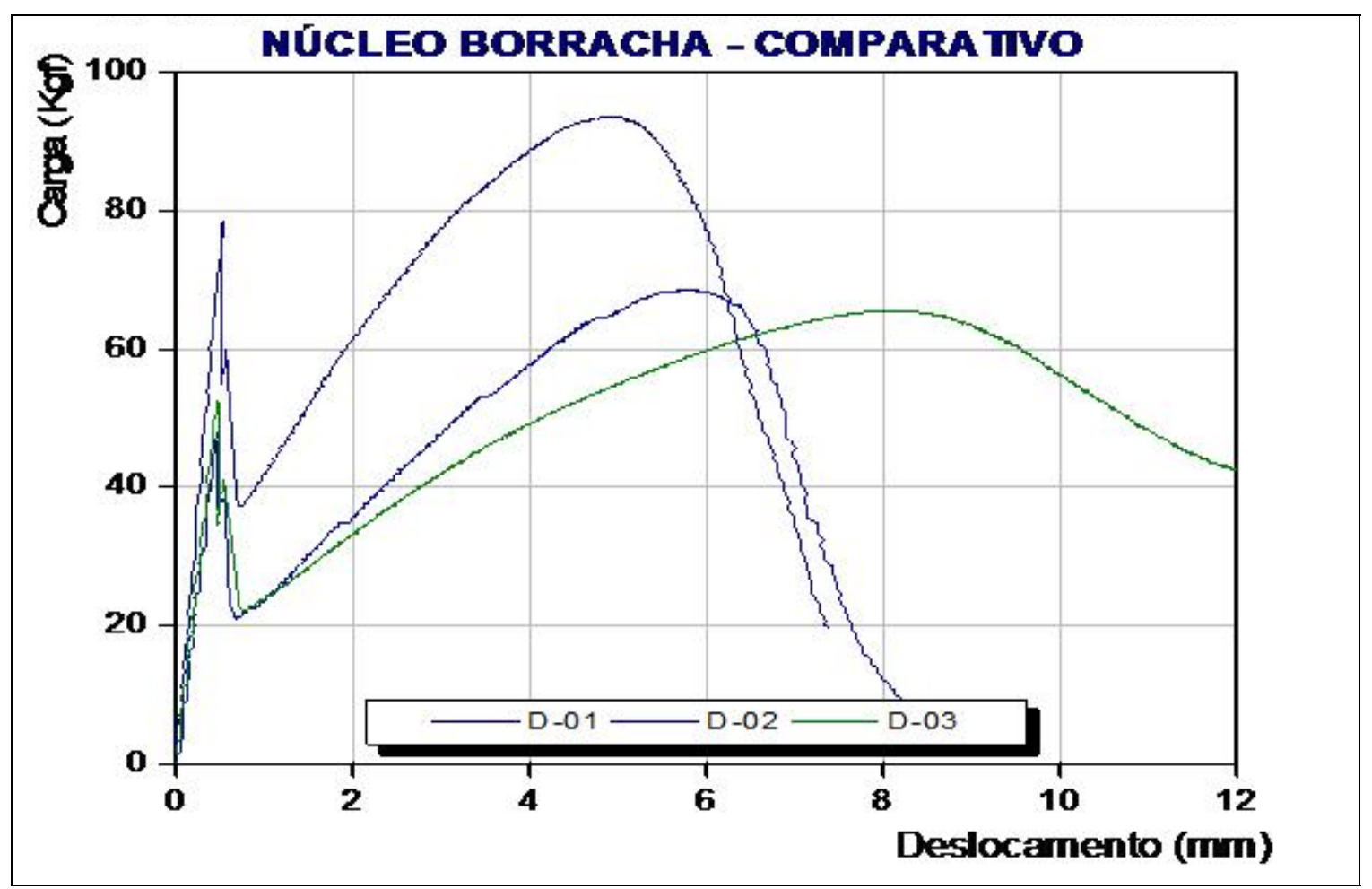

Figura 10.6 - Comparativo de carga à flexão: Sanduíche borracha com diferentes densidades

O comportamento geral, bem como as propriedades mecânicas do compósito PU x Borracha, mostrou-se satisfatório nestes ensaios. Pode-se concluir que os produtos obtidos com os resíduos possuem características favoráveis para a sua utilização na construção civil, portanto, os resíduos utilizados nesta pesquisa devem ser valorizados como matérias-primas, com possibilidade de transformação em novos produtos.

A análise desses dados mostra a potencialidade desse material composto para ser usado como núcleo de painéis, pois se revela em bom isolante térmico.

\subsection{Aparelhos de Apoio para Estruturas}

Considerando o bom desempenho mecânico do compósito desenvolvido neste trabalho, notadamente à compressão, foi intentada a produção de peças para serem colocadas entre elementos estruturais, metálicos ou de concreto armado, conhecidas como aparelhos de apoio. 
As peças desse tipo existentes no mercado são constituídas por elastômeros à base de neoprene e apresentam custo elevado. Sua utilização se justifica no caso de obras submetidas a cargas cíclicas e de alta magnitude.

Para obras mais simples, como no caso de passarelas, pontes e pequenos viadutos de vias vicinais, a utilização de elastômeros à base de neoprene constitui um custo adicional significativo, o que acaba contribuindo para que esses elementos de apoio sejam eliminados do projeto. Esta condição despertou o interesse em se desenvolver um elemento constituído por um material barato, e com condições de atender às exigências específicas dos aparelhos de apoio usados em estruturas.

Os aparelhos de apoio desenvolvidos neste trabalho são constituídos por três placas de compósito de borracha de pneus inservíveis e PU e duas placas metálicas internas, medindo 3,2 cm de espessura total. A Figura 10.7 apresenta a confecção da placa e o aparelho de apoio finalizado.

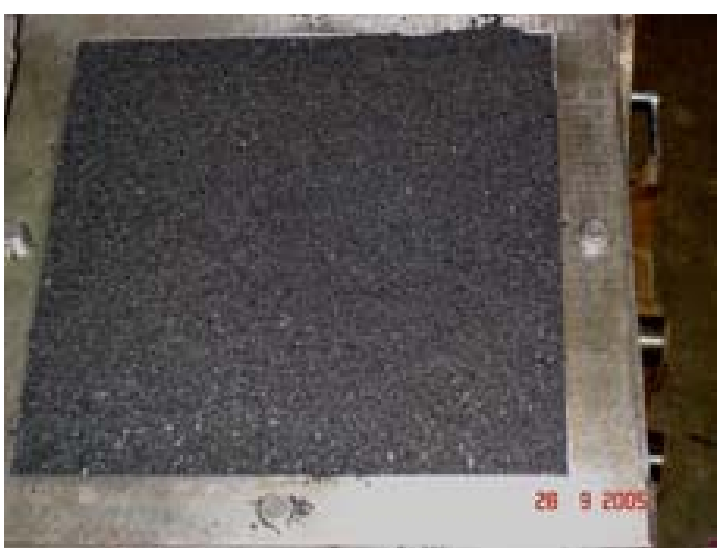

a) Confecção das placas

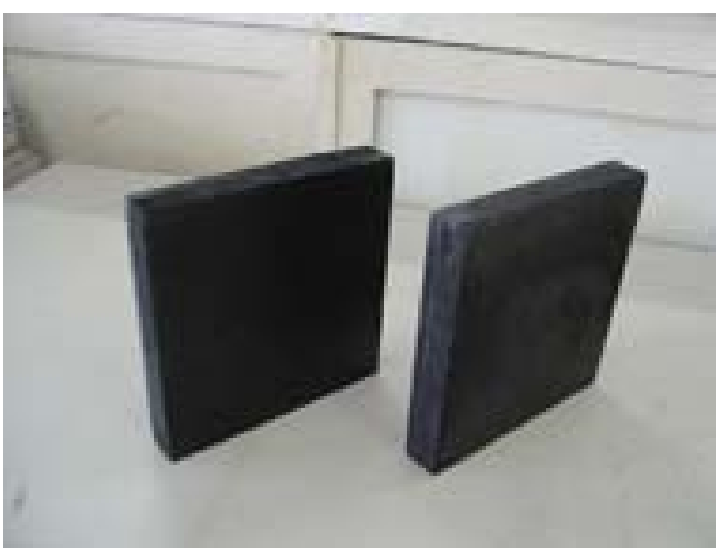

b) Aparelho de apoio

Figura 10.7 - Produção do elemento Aparelho de apoio

Para a avaliação desse elemento experimental, submetido ao carregamento e a uma força perpendicular, simulando sua condição normal de trabalho como aparelho de apoio, foi desenvolvido um esquema de ensaio mostrado na Figura 10.8. 


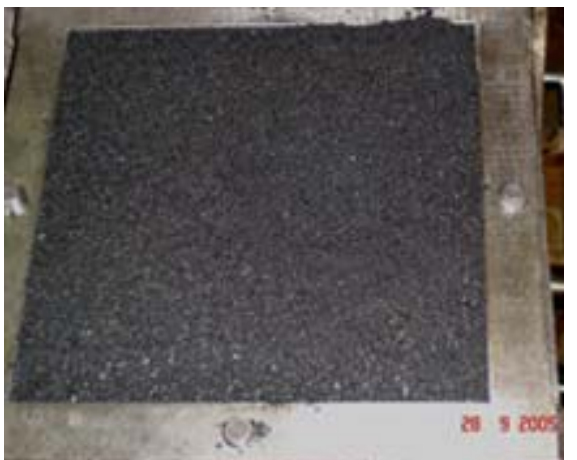

(a)

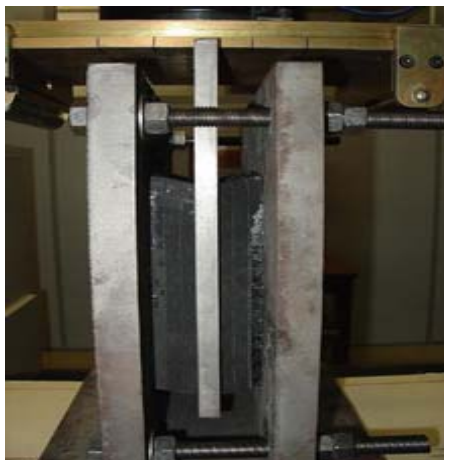

(b)

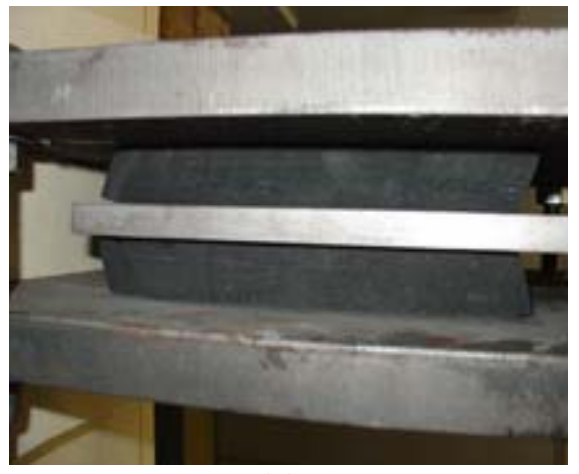

(c)

Figura 10.8 - (a) Montagem do aparelho de apoio no dispositivo para ensaio de distorção , (b) ensaio de distorção e (c) Aparelho de apoio deformado

\subsubsection{Resultados dos experimentos}

Na Tabela 10.2 estão constando os valores encontrados nesse ensaio e nas Figuras 10.9 e 10.10 as curvas tensão x deformação e carga x deslocamento, respectivamente.

Tabela 10.2 - Valores encontrados no ensaio do elemento "aparelho de apoio"

\begin{tabular}{ccc}
\hline Tensão x Deformação & Tensão ( $\boldsymbol{\sigma}$ MPa) & Deformação $(\boldsymbol{\varepsilon} \%)$ \\
\hline & 19,93 & 12,38 \\
\hline
\end{tabular}

\begin{tabular}{ccc}
\hline Carga x Deslocamento & Carga $(\mathbf{N})$ & Deslocamento $(\mathbf{m m})$ \\
\hline & 47.500 & 18,5 \\
\hline
\end{tabular}

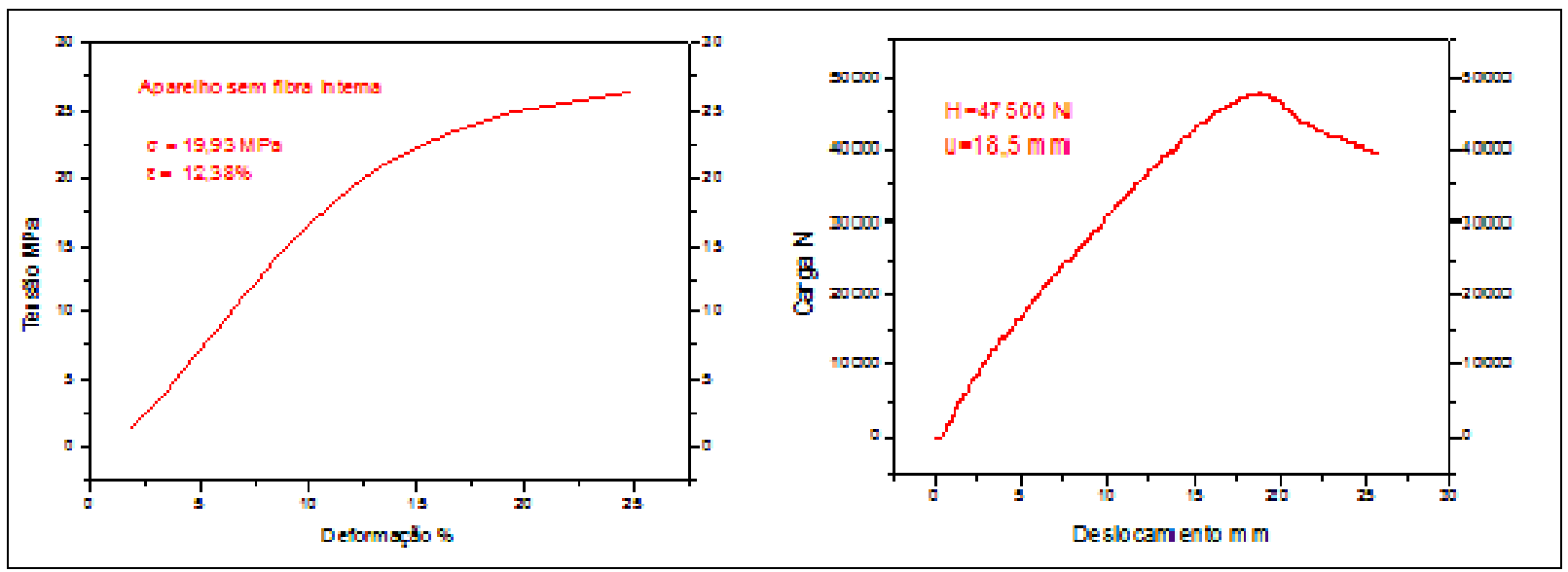

Figura 10.9 - Tensão x Deformação

Figura 10.10 - Carga x Deslocamento 


\subsubsection{Propriedades do Material}

$\mathrm{Na}$ fase de desenvolvimento do aparelho de apoio foram feitos testes com diferentes níveis de prensagem das laminas de compósito, em conjunto com as chapas de aço intermediárias durante a etapa de colagem.

Também foram feitos testes preliminares com telas de fibra de vidro dispostas entre as placas de compósito, com o propósito de avaliar os efeitos do cisalhamento. Acabou-se por não utilizar essas telas de fibra de vidro, em razão de reduzirem a mobilidade do elemento sob efeito de carga paralela às placas.

\subsubsection{Propriedades típicas dos elastômeros empregados em aparelhos de apoio}

Promovendo-se um levantamento sobre as exigências impostas aos aparelhos de apoio, chegou-se aos seguintes parâmetros:

- Grande deformabilidade: alguns elastômeros podem atingir deformações de $1000 \%$ sem rotura e recuperar a forma original.

- Baixo Módulo de Elasticidade: permite atingir grandes deformações mesmo com tensões baixas.

- Grande capacidade de acumular energia: a sua grande capacidade de recuperação após grande deformação permite acumular mais energia do que qualquer outro material.

- Aumento da rigidez com a descida da temperatura.

- Envelhecimento: as propriedades do elastômero se alteram com o tempo, principalmente devido a fenômenos de oxidação. A correta escolha da composição do elastômero pode minimizar esse efeito. 
Todas essas propriedades estão muito próximas do compósito de borracha aglomerada com PU, cujas características encontram-se a seguir na Tabela $10.3^{12}$.

Tabela 10.3 - Características físicas e químicas do compósito

\section{Densidade}

Tensão normal

Deformação pela tensão normal

Carga horizontal

Deformação pela carga horizontal

Dureza escala Shore "A"
$1,16 \mathrm{~g} / \mathrm{cm}^{3}$

$19,93 \mathrm{MPa}$

$12,38 \%$

$47.500 \mathrm{~N}$

$18,5 \mathrm{~mm}$

75

A relação tensão-deformação de um bloco de elastômero depende muito da forma do bloco utilizado. Se o bloco for fino e com uma grande seção transversal, a sua rigidez será muito maior do que seria se a relação entre a altura e a seção transversal fosse elevada $\mathrm{A}$ rigidez do bloco depende muito da sua capacidade de deformação lateral. Na Figura 10.11 apresenta-se, esquematicamente, a relação de forma do bloco submetido ao carregamento.

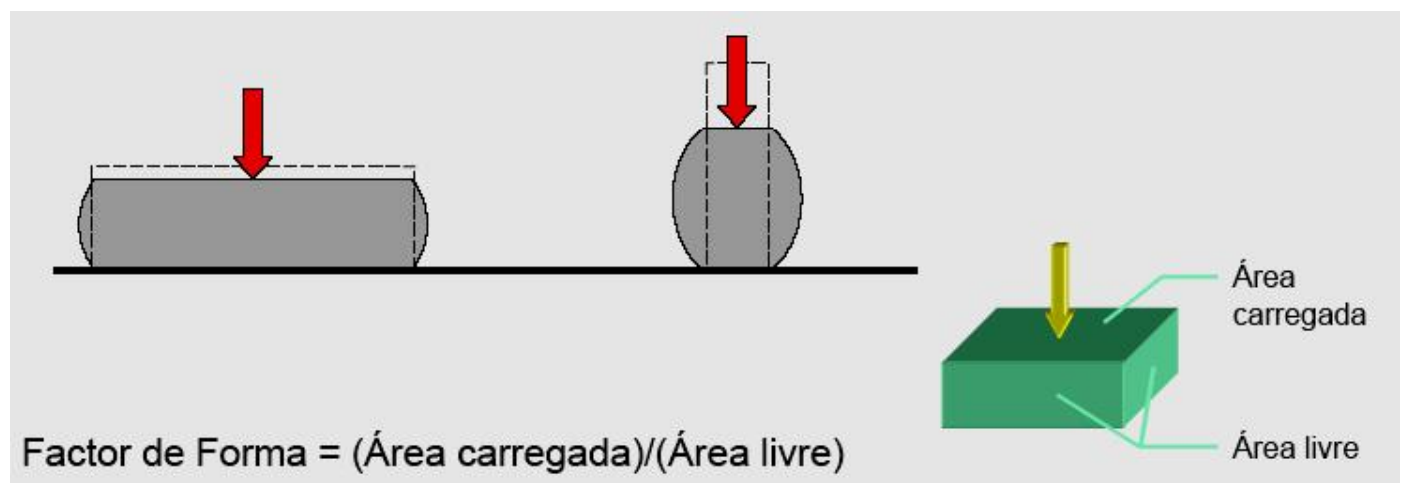

Figura 10.11 - Deformação dos corpos de prova

\footnotetext{
12 Essas características foram detalhadas nos Capítulos 8 e 9.
} 


\subsubsection{Fator de forma}

Define-se o Fator de forma (S) de uma camada de espessura $t_{i}$ de acordo com a equação (1). Para aparelhos fretados ${ }^{13}$, a e b são as dimensões comuns entre o elastômero e as chapas de aço.

$$
S=\frac{a * b}{2 * t_{i}(a+b)}
$$

$t_{i} \Rightarrow$ espessura para camadas de elastômero de aparelhos fretados.

\subsubsection{Dureza}

A dureza do elastômero não é uma grandeza importante por si só. Somente tem interesse como um indicador da rigidez do composto, com a vantagem da sua medida não depender da forma do bloco de elastômero.

A Tabela 10.4 apresenta a relação entre o Módulo de elasticidade transversal (G) e a dureza do elastômero, válida para pequenas deformações.

Tabela 10.4 - Valores típicos para o Módulo de elasticidade transversal em função da dureza do elastômero

\begin{tabular}{cc}
\hline Dureza Shore "A" & $\begin{array}{c}\text { Módulo de elasticidade transversal - G } \\
\text { (MPa) }\end{array}$ \\
\hline 50 & 6 \\
60 & 9 \\
70 & 12 \\
75 & 13,5 \\
\hline
\end{tabular}

13 Aparelho de apoio fretado corresponde ao elemento com laminas metálicas dispostas entre placas do elastômero. 


\subsubsection{Propriedades dinâmicas dos elastômeros}

\subsubsection{Influência da freqüência no valor de G (MPa)}

Os elastômeros não são perfeitamente elásticos, apresentam algum amortecimento interno e a rigidez tem tendência a aumentar quando a freqüência de deformação aumenta. Esta última característica só é aparente para freqüências de deformação muito superiores àquelas que ocorrem em aparelhos de apoio de estruturas.

Recomenda-se que o elastômero utilizado na fabricação dos blocos de apoio seja a borracha natural (NR - natural rubber) ou o Cloroprene (CR), também conhecido como neoprene. No processo de fabricação pode ainda ser utilizado outro polímero, desde que a percentagem desse material não ultrapasse 5\% da mistura, e o Módulo de Elasticidade Transversal (G) deve estar compreendido entre os valores da Tabela 10.5.

Tabela 10.5 - Módulo de elasticidade transversal em relação ao peso dos blocos de apoio

\begin{tabular}{cc}
\hline Porcentagem do peso para blocos de apoio & G (MPa) \\
\hline $60 \%$ & 0,7 \\
\hline $55 \%$ & 0,9 \\
\hline $50 \%$ & 1,15 \\
\hline
\end{tabular}

\subsubsection{Rigidez Vertical}

A deformação vertical de uma lâmina de elastômero resulta da soma de dois componentes de deformação de origem distinta. Uma primeira parcela é devida à deformação da lâmina por distorção $(\operatorname{Kv}(\gamma))$, enquanto a outra componente resulta da variação de volume da camada de elastômero $(\operatorname{Kv}(v))$. 
Assumindo que a deformação total é a soma das duas componentes de deformação, obtém-se a seguinte expressão (2) para o cálculo da rigidez vertical:

$$
K_{v}=\frac{K_{v}(\gamma) K(v)}{K_{v}(\gamma)+K_{v}(v)}
$$

$K_{v}(\gamma)=\beta_{2} \frac{G S^{2} A}{h_{e l}} \rightarrow$ (rigidez vertical devido à distorção)

$K_{v}(v)=\frac{E_{b} A}{h_{e l}} \rightarrow($ rigidez por variação de volume $)$

$E_{b}$ :módulo de compressibilidade de elastômero $\left(E_{b} \approx 2000 \mathrm{MPa}\right)$.

$G$ :módulo de distorção do elastômero ( $G \approx 0,7$ a $2.0 M P A)$.

$\beta_{2}$ : coeficiente que depende da forma da secção.

$h_{e l}$ : altura total do elastômero $\left(h_{e l}=26 \mathrm{~mm}\right)$.

O Fator de Forma, considerando o tipo de seção do aparelho de apoio, apresenta interferência sobre o seu comportamento e a Tabela 10.6 apresenta os parâmetros.

Tabela 10.6 - Constante para fator de forma

(Kelly, 1993)

(CEN/TC 167, 2001)

\begin{tabular}{ccc} 
Bloco com secção circular & 6 & 5 \\
Bloco com secção quadrada & 6,73 & 5 \\
\hline
\end{tabular}

A deformação vertical de um conjunto de lâminas de elastômero pode ser calculada a partir da rigidez vertical de cada uma das camadas $K_{v i}$ :

$$
K_{v}=\frac{1}{\sum \frac{1}{K_{v i}}} \text { (rigidez vertical de um conjunto de camadas) }
$$


Se as camadas forem todas iguais, a expressão anterior pode ser simplificada tomando a seguinte forma, conforme equação (3):

$$
K_{v}=\frac{K_{v i}}{n}
$$

$n$ corresponde ao número de camadas

\section{No aparelho de apoio proposto neste trabalho foi encontrado:}

No ensaio a compressão: para $250 \mathrm{kN}$ de carga em uma seção de 190 mm x190 mm

$$
\begin{gathered}
\partial \ell=1,28 \mathrm{~mm} \\
\ell=26 \mathrm{~mm}
\end{gathered}
$$

$$
\varepsilon=1,28 / 26=0,049 \times 100=4,9 \%
$$

Para uma carga de $250 \mathrm{kN}$ (área de $190 \mathrm{~mm}$ x $190 \mathrm{~mm}$ ) tem-se, conforme representa a

Figura 10.12:

$$
\therefore G=250000 / 36100=6,92 \mathrm{~N} / \mathrm{mm}^{2}
$$

$$
\therefore E_{b}=6,92 / 0,049=141,33 \mathrm{MPa}
$$

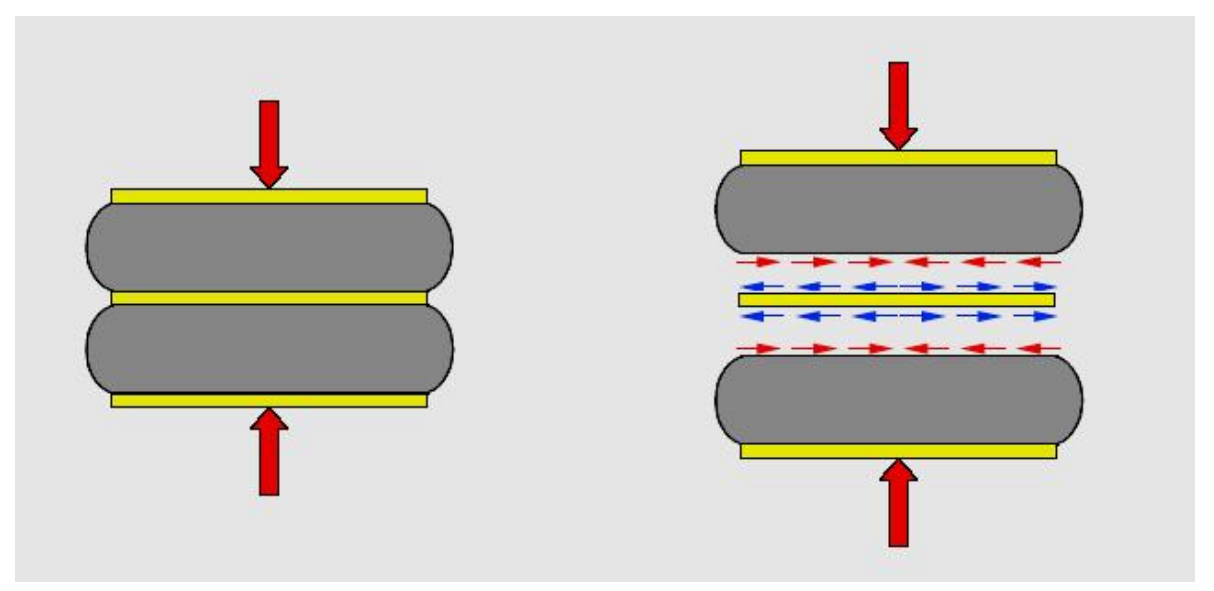

Figura 10.12 - Cargas atuantes no conjunto de camadas do aparelho de apoio 


\subsubsection{Rigidez Horizontal}

No caso de blocos de elastômero cintado o valor da rigidez do conjunto pode ser calculado a partir do valor do módulo de distorção $(\mathrm{G})$ do elastômero que o constitui. Como o bloco é constituído pela justaposição de camadas de elastômero, a deformação horizontal do conjunto é o somatório das deformações individuais de cada camada. Por seu lado, a deformação de cada camada, devido à sua pequena espessura, é essencialmente por corte.

Dessa forma, a relação entre a rigidez do bloco e o módulo de distorção obedece à seguinte expressão (4):

$$
K_{h}=\frac{G A}{h_{e l}}
$$

$G \Rightarrow$ módulo de distorção do elastômero;

$A \Rightarrow$ área em planta do bloco;

$h_{e l} \Rightarrow$ altura total do elastômero (somatório das espessuras das várias camadas)

Se a carga vertical sobre o bloco for próxima da carga crítica (Ncr), então a rigidez horizontal do bloco deve ser calculada através das seguintes expressões $(5,6)$ :

$$
\begin{array}{r}
K_{h}=\frac{G A}{h_{e l}}\left(1-\frac{N^{2} h_{e l}}{G A h_{T} N_{E}}\right) \\
G=\frac{(T H)}{u A}
\end{array}
$$

No aparelho de apoio proposto foi encontrado:

$T=26 \mathrm{~mm}$

$H=47,5 k N$

$\therefore G=1,85 \mathrm{~N} / \mathrm{mm}^{2}$

$u=18,5 \mathrm{~mm}$ 
$A=36100 \mathrm{~mm}^{2}$

$G$ :módulo de distorção $\left(G=1,85 \mathrm{~N} / \mathrm{mm}^{2}\right)$

$A$ :área em planta do bloco $\left(A=36100 \mathrm{~mm}^{2}\right)$

$h_{e l}$ : altura total de elastômero (somatório das várias camadas) $\left(h_{e l}=26 \mathrm{~mm}\right)$

$h_{T}$ : altura total do bloco $\left(h_{T}=30 \mathrm{~mm}\right)$

$N$ carga vertical sobre o bloco $(N=240 \mathrm{kN})$

$N_{E}$ carga vertical de Euler

Nas Figuras 10.13, 10.14, 10.15 e 10.16 são apresentados os esquemas de carregamentos em conformidade com o que dispõe a Norma Européia CEN/TEC 167 N 185 $(\text { Maio 2001) })^{14}$.

A carga vertical de Euler pode ser calculada através da seguinte expressão (7):

$$
N_{E}=\beta_{1} \pi^{2} \frac{G S^{2} I}{h_{T} h_{e l}}
$$

$S \Rightarrow$ fator de forma da secção, obtido pela relação entre a área carregada e a área livre de carga do bloco, considerando somente a altura total de elastômero:

$$
\text { seção retangular } S=a \times b
$$

Substituindo os valores na equação (2), tem-se:

$a=190 \mathrm{~mm}$

$b=190 \mathrm{~mm}$

$$
\therefore S=5,48
$$

$t_{i}=8,67$

14 Comportamento de Blocos de Elastómero (Borrachas), Guerreiro, L.- Abril 2003. Disponível em: http://www.civil.ist.utl.pt/ luisg/textos/borrachaAbr03.pdf 
$I$ :momento de inércia da secção;

$t$ : espessura de uma camada de elastômero;

$b_{1}$ : coeficiente definido em função da forma do bloco, bloco quadrado: $b_{1}=2,214$

Pré Norma Europeia $\quad$ CEN/TC 167 N 185 (Maio 2001)

Máxima distorção:

$$
\varepsilon_{\mathrm{t}, \mathrm{d}}=\varepsilon_{\mathrm{c}, \mathrm{d}}+\varepsilon_{\mathrm{q}, \mathrm{d}}+\varepsilon_{\alpha, \mathrm{d}}
$$

$\varepsilon_{c, d}$ - distorção devido às cargas de compressão

$\varepsilon_{q, d}$-distorção devido aos movimentos horizontais

$\varepsilon_{\alpha, d}$ - distorção devido à rotação

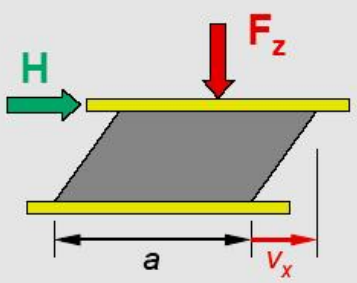

$$
\varepsilon_{t, d}<5
$$

$$
\varepsilon_{c, d}=\frac{1.5 F_{z, d}}{G A_{r} S} \quad A_{r}=A\left(1-\frac{v_{x, d}}{a}-\frac{v_{y, d}}{b}\right)
$$

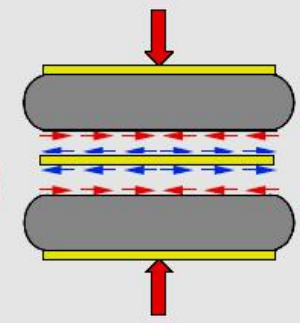

Figura 10.13 - Esquema das cargas atuantes no aparelho de apoio

$\mathrm{A}_{\mathrm{r}}=\mathrm{A}$

$\mathrm{F}_{\mathrm{z}, \mathrm{d}}=240 \mathrm{kN}$

$\mathrm{A}=190 \mathrm{~mm}$

$\mathrm{V}_{\mathrm{x}, \mathrm{d}}=18,5 \mathrm{~mm}$

$\mathrm{G}=1,85 \mathrm{~N} / \mathrm{mm}^{2}$

$\varepsilon_{c, d}=1,5 \times 240000 / 1,85 \times 36100 \times 5,48=0,98$ 


\section{Pré Norma Europeia $\quad$ CEN/TC 167 N 185 (Maio 2001)}

$$
\begin{aligned}
& \varepsilon_{q, d}=\frac{V_{x y, d}}{T_{q}} \quad \varepsilon_{q, d}<0.7 \\
& V_{x y, d}-\text { máximo deslocamento horizontal } \\
& t_{q}-\text { espessura total de elastómero }
\end{aligned}
$$

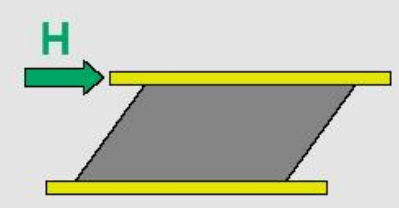

$$
\varepsilon_{\alpha, d}=\frac{\left(a^{2} \alpha_{a, d}+b^{2} \alpha_{b, d}\right) t_{i}}{2 \Sigma\left(t_{i}^{3}\right)}
$$

$\alpha_{a, d}$ - ângulo de rotação ao longo de a

$\alpha_{b, d}$ - ângulo de rotação ao longo de $\mathbf{b}$

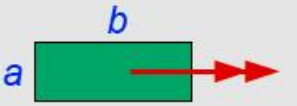

$t_{i}$ - espessura de cada camada de elastómero

Figura 10.14 - Esquema das cargas atuantes no aparelho de apoio

$$
\begin{aligned}
& \mathrm{t}_{\mathrm{q}}=26 \mathrm{~mm} \\
& \mathrm{v}_{\mathrm{xy}, \mathrm{d}}=18,5 \mathrm{~mm} \\
& \mathrm{H}=47,5 \mathrm{~N} / \mathrm{mm}^{2} \\
& \alpha_{\mathrm{a}, \mathrm{d}}=\alpha_{\mathrm{b}, \mathrm{d}} \\
& \mathrm{t}_{\mathrm{i}}=8,67 \mathrm{~mm} \\
& \varepsilon_{q, d}=18,5 / 26=0,71
\end{aligned}
$$

Máxima distorção:

$$
\varepsilon_{t, d}=\varepsilon_{c, d}+\varepsilon_{q, d}=0,98+0,71=1,69
$$


Pré Norma Europeia

Chapas de reforço:

$t_{s}=\frac{K_{p} F_{z . d}\left(t_{1}+t_{2}\right) \gamma_{m} \gamma_{f}}{A_{r} f_{y}}$

$\mathrm{t}_{\mathrm{s}} \geq 2 \mathrm{~mm}$

$t_{1}$ e $t_{2}$ - espessura de elastómero de cada lado da chapa de açı

$\mathrm{f}_{\mathrm{y}}$ - tensão de cedência do aço

$\gamma_{m}$ - Factor de segurança parcial

$$
\gamma_{m}=1 \text { (sem buracos) }
$$$$
\gamma_{\mathrm{m}}=2 \text { (com buracos) }
$$

$\gamma_{f}-$ factor de segurança parcial $\left(\gamma_{f}=1\right)$

$K_{p}$ - factor de correcção $\left(K_{p}=1.3\right)$

Figura 10.15 - Esquema das cargas atuantes no aparelho de apoio

\section{Verificação da estabilidade ao rolamento}

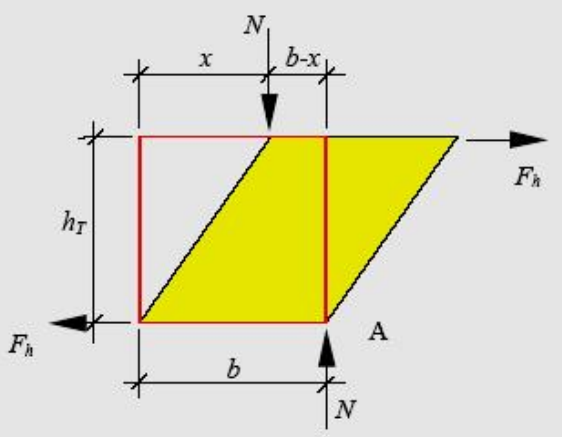

$$
\begin{aligned}
F_{h} & =K_{h} x_{\max } \\
K_{h} & =\frac{G A}{h_{e l}} \\
\sigma_{N} & =\frac{N}{A}
\end{aligned}
$$

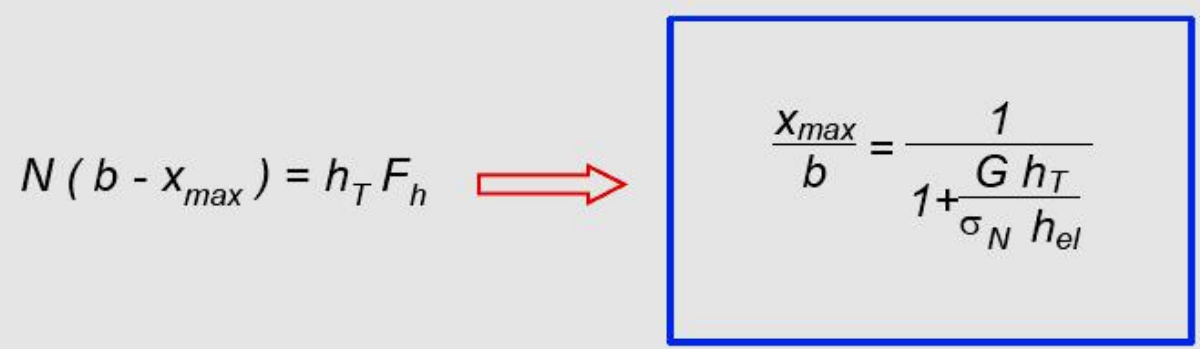

Figura 10.16 - Esquema das cargas atuantes no aparelho de apoio

$b=190 \mathrm{~mm}$

$F_{h}=47,5 \mathrm{kN}$ 
$N=240 k N \quad$ (N é a força que foi aplicada na compressão pelos barrões nos três aparelhos de apoio)

$h_{t}=30 \mathrm{~mm}$

$h_{e l}=26 \mathrm{~mm}$

$x_{\max }=18,5 \mathrm{~mm}$

$\sigma_{N}=N / A=240000 / 36100=6,65 \mathrm{~N} / \mathrm{mm}^{2}$

\subsection{Funcionalidade e Campo de Aplicação}

A partir dos resultados obtidos com o compósito em estudo, pode-se considerá-lo potencialmente utilizável para situações que demandem:

- Acomodação de movimentos de translação e rotação, mantendo o equilíbrio de deslocamentos de um componente estrutural a outro;

- Combinados a sistemas deslizantes permanentes ou temporários ou sistemas de restrição de movimentos, estendem seu campo de utilização;

- Proteção contra terremotos;

- Durabilidade proporcional à estrutura (em ambiente não agressivo);

\subsubsection{Aplicação de Aparelhos de Apoio}

O emprego de aparelhos de apoio pode ser estendido a outros campos de aplicação, além daqueles normalmente considerados, e restritos a elementos estruturais, tão somente. $\mathrm{Na}$ Figura 10.17 pode-se verificar uma possível utilização desse compósito. 
Um grande número de aplicações desse compósito a base de borracha e PU podem vir a ser concretizado nas seguintes obras:

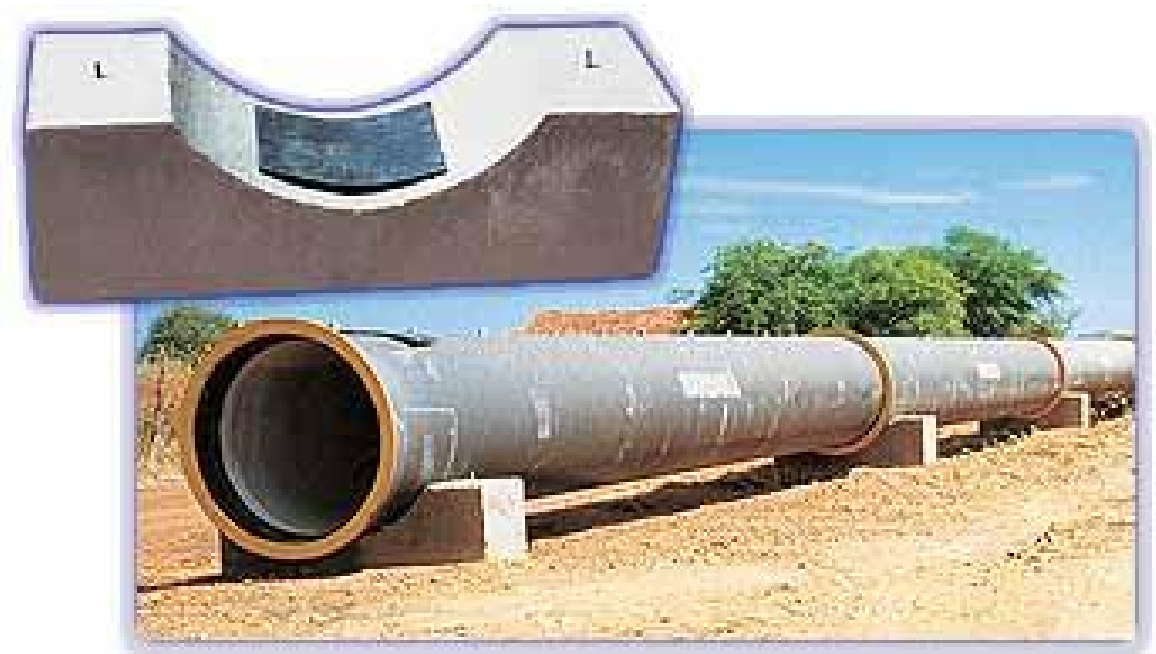

Figura 10.17 - Exemplo de uma aplicação potencial para o compósito desenvolvido

- Estruturas pré-fabricadas de concreto;

- Estruturas metálicas;

- Silos e reservatórios;

- Periferia em edifícios;

- Pilares centrais de pontes;

- Apoios extremos de pontes em viga contínua de grande extensão, quando recebem uma camada de teflon sobre a qual desliza uma chapa de aço inox;

- Apoios de pontes com grande esconsidade, quando muitas vezes são circulares em planta;

- Amortecedores de máquinas em indústrias;

- Apoios de comportas;

- Apoios de sistemas de rolamento de metrôs etc.;

- Defensas Portuárias, Marítimas e Proteção de Pilares. 
As partículas de borracha adquiridas de usinas de moagem de pneus não passam por uma seleção inicial, sendo moídas todas as espécies de pneus com diferentes características e usos dos mais variados tipos. Promovendo-se tal seleção seria possível obter compostos dotados de propriedades mais próximas dos elastômeros empregados nos aparelhos de apoio convencionais.

Também podem ser utilizados outros tipos de resina PU de origem vegetal, dotadas de maior capacidade de deformação e alto poder de adesividade, o que juntamente com a préseleção da borracha permitiria a obtenção de propriedades mais condizentes com os elastômeros convencionais empregados nos aparelhos de apoio.

A utilização desse compósito, considerando que se encontra em desenvolvimento deve estar restrita a obras de baixa responsabilidade, onde são encontradas cargas e deformações de pequena magnitude, situação encontrável em elementos constituintes de pequenas pontes de estradas vicinais, de madeira, perfis metálicos ou de concreto armado, ligação de elementos estruturais e alvenaria, em edifícios de baixa altura, bases de máquinas, coxins e elementos absorvedores de impacto, tais como defensas de estradas ou elementos de sinalização horizontal, montados sobre o pavimento.

Na figura 10.18 apresenta o aparelho de apoio com as dimensões 200 X 200 mm já sendo utilizado na ETE de São Carlos localizado no consolo da escada de acesso a calha Parshall (medidor de vazão). 


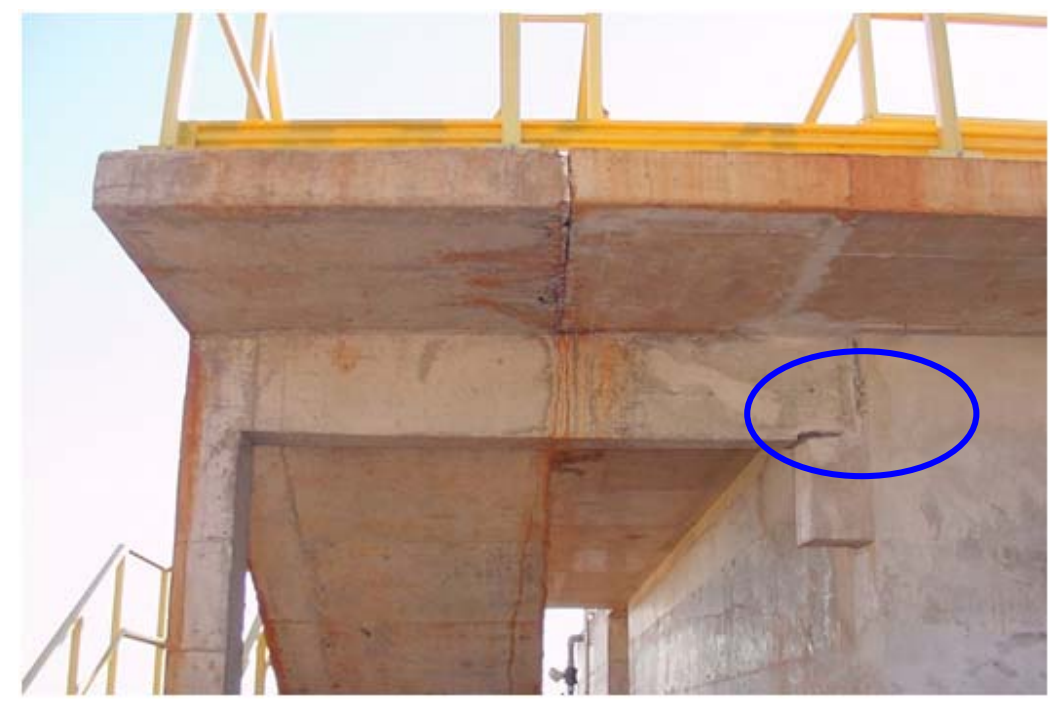

Figura 10.18 - Apresenta o aparelho de Apoio aplicado na ETE São Carlos 


\section{CONCLUSÕES}

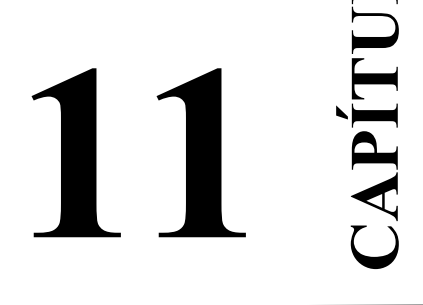

Nos capítulos anteriores apresentaram-se conclusões parciais e discussões de resultados obtidos nos diferentes ensaios, e neste capítulo a intenção é no sentido de uma análise geral para fechar este trabalho.

Para o resíduo de borracha proveniente de pneus inservíveis ficou demonstrada sua viabilidade de utilização na forma de compósito, quando associado a uma resina poliuretana de origem vegetal.

A composição granulométrica das partículas de borracha deve possibilitar a máxima compacidade, e para isto o método de Ruthfuchs mostrou-se adequado.

O compósito de borracha e resina PU que melhor resultado apresentou foi aquele com teor de resina de 18\% no traço em massa $2: 1$ (poliol : pré-polímero), com granulometria enquadrada na zona 3.

Para a produção do compósito se faz necessária sua compactação no molde com aplicação de calor, numa temperatura entre 90 e $100^{\circ} \mathrm{C}$ para possibilitar a polimerização da resina em um menor tempo e com isto permitir a desforma.

A resistência à abrasão do compósito mostra-se bastante satisfatória, o que possibilita seu uso como revestimento de pisos. Os resultados obtidos foram semelhantes aos pisos de borracha encontrados comercialmente e superior a de materiais cerâmicos como porcelanato e ladrilhos esmaltados com PEI 5. 
A microscopia eletrônica de varredura - MEV possibilitou a análise do empacotamento dos grãos de borracha aglomerados pela resina poliuretana e norteou a escolha dos teores de resina mais adequados com relação à borracha como também na escolha do processo de produção do compósito.

O comportamento mecânico do compósito, nos ensaios de compressão e tração apresenta semelhança com a borracha retirada de pneu como também de neoprene, empregados para servir de referência neste estudo.

Outros ensaios como de impacto Charpy e rasgamento apresentaram resultados satisfatórios, mas também evidenciam que o melhor desempenho do compósito é obtido para aplicações onde é solicitado predominantemente à compressão.

O compósito apresentou resultado satisfatório com relação à resistividade dielétrica, considerando que a necessidade atual dos pisos reside em se conseguir revestimentos que apresentem condutividade elétrica de alguma intensidade, apta a eliminar a eletricidade estática que se forma em ambientes de trabalho, ao mesmo tempo em que apresenta-se absorvente a impacto e à abrasão.

Com relação aos ensaios dinâmicos-mecânicos como o DMA estes se constituem como uma importante ferramenta para a caracterização de materiais compósitos e cabe ter seu emprego ampliado, principalmente quando se altera a temperatura ambiente.

O ensaio de DMA além de determinar as características termo-analíticas do material, permite caracterizar a sua fluência e relaxação e assim predizer o tempo de vida útil que o mesmo venha a ter sob determinada condição de temperatura.

O comportamento do compósito com relação ao intemperismo sob raios UV constatou que a resina poliuretana de mamona sofre alteração em suas propriedades mecânicas, aumentando seu módulo de elasticidade, como também a temperatura de transição vítrea. 
Como o apresentado no Capítulo 10, o compósito estudado tem um grande potencial de utilização em diferentes setores da construção civil, estando em uso como aparelho de apoio mesmo tendo sido construído em laboratório.

O processo de produção do compósito é bastante simples e o setor produtivo pode vir a incorporar os conhecimentos desenvolvidos neste trabalho, que se constituem aptos para a transferência de tecnologia.

\subsection{Sugestões para pesquisas adicionais}

Ficou explicito neste trabalho o elevado potencial que os produtos derivados da reciclagem dos pneus inservíveis apresentam para o setor da construção civil.

No resíduo dos pneus inservíveis além da borracha se tem as fibras de nylon e as fibras de aço, materiais que podem ser utilizados em matrizes cimentícias ou poliméricas como reforço com o propósito de propiciar maior tenacidade ao compósito com aumento de sua resistência à tração.

As partículas de borracha podem servir de agregado leve em matrizes cimentícias no caso de elementos pré-moldados leves, as chamadas chapas cimentícias, em alternativa à placas de gesso acartonado, quando expostas ao ambiente externo.

Neste tipo de utilização foram efetuados testes preliminares que trouxeram resultados bastante satisfatórios. A Figura 11.1 apresenta o elemento de painel executado com as partículas de borracha utilizadas como agregado leve em placa cimentícia tipo drywall armada com telas de fibra de vidro. 


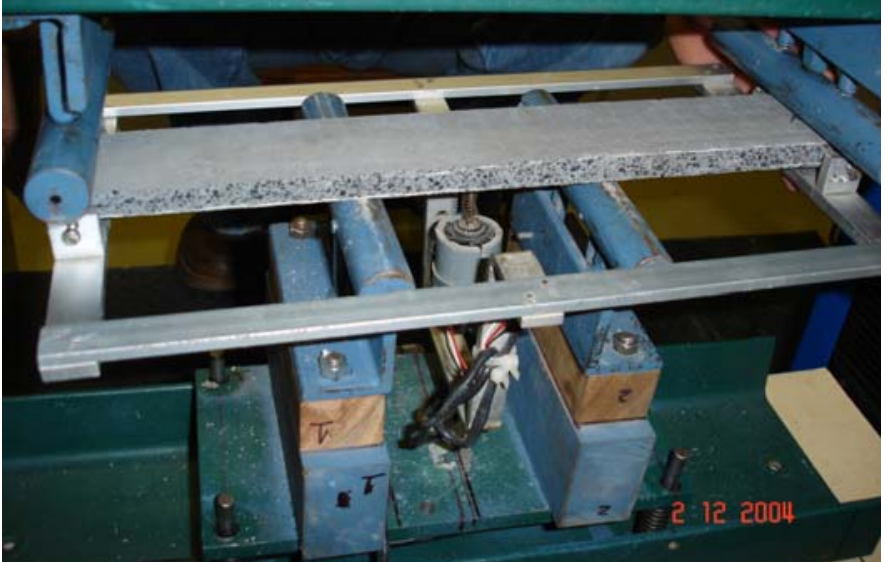

Figura 11.19 - Ensaio à flexão de placa cimentícia com partículas de borracha como agregado

Com relação às fibras de nylon também foram procedidos estudos exploratórios para sua utilização em matriz polimérica, o que deu origem a um pedido de patente junto ao INPI. A Figura 11.2 apresenta um elemento em fibras de nylon envolvidas em matriz polimérica,a base de resina poliuretana derivada de óleo de mamona.
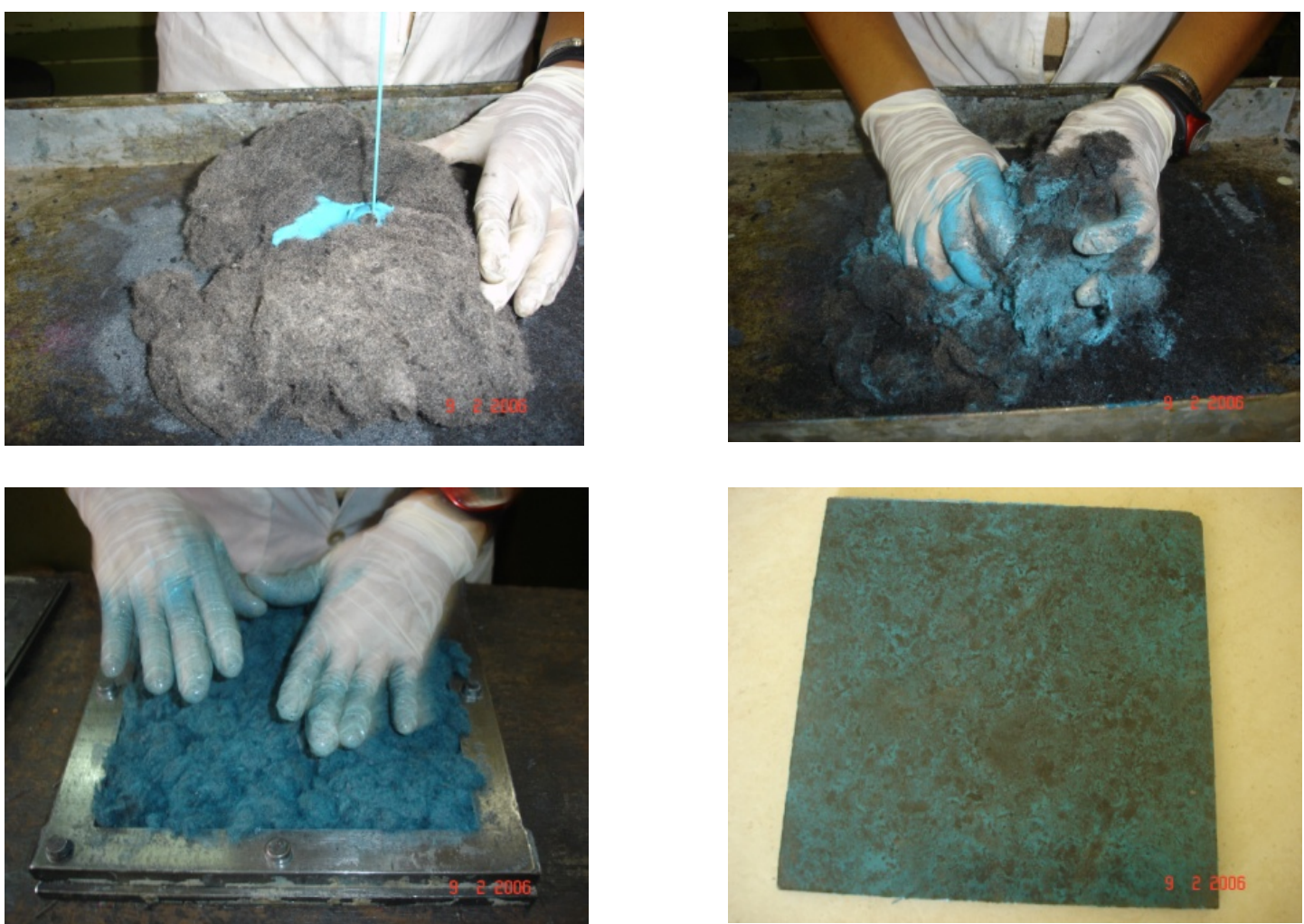

Figura 11.20 - Seqüência de execução de placa com fibras de nylon em matriz polimérica 


\section{REFERÊNCIAS}

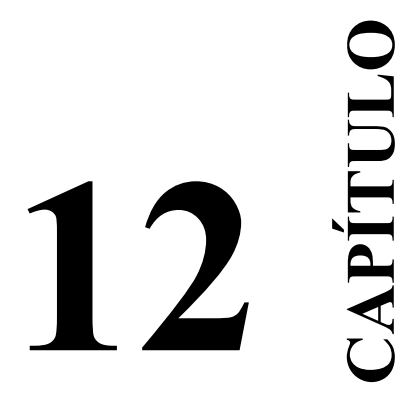

ABNT - Associação Brasileira de Normas Técnicas. NBR 10004 - Resíduos Sólidos. Rio de Janeiro: Associação Brasileira de Normas Técnicas, 1987.

NBR 7211. Agregado para concreto. Especificação. Rio de Janeiro: Associação Brasileira de Normas Técnicas, 2005.

NBR 6936. Técnicas de ensaios elétricos de alta-tensão. Rio de Janeiro: Associação Brasileira de Normas Técnicas, 1992.

NBR 7217. Agregados - Determinação da composição granulométrica. Rio de Janeiro: Associação Brasileira de Normas Técnicas, 2003.

ALFREY, T.; GURNEE, E. F. Polímeros orgânicos. São Paulo: Edgard Blücher, 1971.

ALMEIDA, A. E. F.; FERREIRA, O. P. Características mecânicas e viscoelásticas da resina poliuretana derivada de materiais oleoquímicos exposta ao intemperismo artificial. Revista Iberoamericana de Polímeros. v.7, ano 2, p. 87-97, mar., 2006.

ALTAFIM, R. A. C. et al. Resinas poliuretanas derivadas do óleo de mamona usadas na fabricação de isoladores poliméricos - parte III. In: Encontro Nacional de Engenharia de Alta Tensão. Campina Grande, 2000.

ANIP - Associação Nacional de Indústrias de Pneumáticos. Entrevista Aberta: Sr. José Carlos Arnaldi, Assessor da Presidência - Sede da ANIP, São Paulo/SP, jul. 2002.

ARAÚJO, L. C. R. Caracterização química, térmica e mecânica de poliuretanas elastoméricas baseadas em materiais oleoquímicos. São Carlos, 105p. Dissertação (Mestrado) - Instituto de Física e Química de São Carlos, Universidade de São Paulo, 1992.

ASTM - American Society for Testing and Materials. D 624-00. Standard Test Method for Tear Strength of Conventional Vulcanized Rubber and Thermoplastic Elastomers. 2007. 
D 792-00. Standard Test Methods for Density and Specific Gravity (Relative Density) of Plastics by Displacement.

D 638 M. for Tensile Properties of Plastics.

D 695 M. Standard Test Method for Compressive Properties of Rigid Plastics. 1987.

D 1004-94a. Standard test Method for initial tear resistance of plastic film and sheeting. 2003.

D 2240-9-7. Rubber Property- Durometer Hardeness.

D 5963-04. Standard Test Method for Rubber Property - Abrasion Resistance (Rotary Drum Abrader).

G-154. Operating Light and Water-Exposure Apparatus (Fluorescent UVCondensation Type) for Exposure of Nonmetalic Materials.

BERTOLLO, S. A. et al. Pavimentação asfáltica: Uma alternativa para a reutilização de pneus usados. Limpeza Urbana, no 54, p. 23-30, janeiro, 2000.

BIDONE, F. R. A. Conceitos básicos de resíduos sólidos. São Carlos: EESC/USP, 1999.

BRASIL. Ministério do Desenvolvimento, Indústria e Comércio, Secretaria de Política Industrial. PBR - Programa Brasileiro de Reciclagem. Brasília: Ministério do Desenvolvimento, Indústria e Comércio, Secretaria de Política Industrial, 1999. v. 1. Bases para o seu Desenvolvimento Estratégico.

CAMPINAS. Lei $\mathbf{n}^{\mathbf{0}} \mathbf{1 0 . 2 8 9}$, de 20 de outubro de 1999. Obriga as Empresas Que Comercializam Pneus, Pilhas e Baterias Novas à Base de Metais Pesados como o Cádmio, Cromo, Zinco ou Mercúrio, a Possuírem Locais Seguros para Recolhimento dos Usados e a Fixarem Placas com Informações sobre os Prejuízos Causados pelos Produtos ao Meio Ambiente e Dá Outras Providências. Disponível em: <http://www.campinas.sp.gov.br/bibjuri/ lei10289.htm>. Acesso em: 12 mai. 2008.

CAMPOS, C. I.; LAHR, F. A. R. Production and characterization of MDF using Eucalyptus Fibers and Castor-oil-based Polyurethane Resin. Materials Research, v.6, Jul-Set, 2004.

CEMPRE - Compromisso empresarial para reciclagem. Pneus. Disponível em: $<$ http://www.cempre.org.br/cempre_institucional.php> Acesso em: 20 mai. 2008. 
CEN/TC 167/WG: European Standard on Structural Bearings, 2001.

CETESB - Companhia Estadual de Tecnologia e Saneamento Básico. Disposição de pneus em aterros. Boletim Informativo - Solo / Resíduos Sólidos, 2002. Disponível em: $<$ http://www.cetesb.sp.gov.br>. Acesso em: 18 mai. 2008.

CHATFIELD, H. W. The science of surface coatings. London: Ernest Benn Limited, 1962.

CIMINO, M. A., BALDOCHI, V. M. Z. Minimização de resíduos sólidos urbanos alternativas tecnológicas para pneumáticos inservíveis. UNISANTA, UFSCAR, 2002.

CONAMA - Conselho Nacional do Meio Ambiente. Resolução no 258. Brasília: Ministério do Meio Ambiente, 2p, 26 de agosto de 1999.

COSTA, J. T. Reaproveitamento de sucata de pneus. Inviabilidade técnica ou econômica? Limpeza Urbana. ABLP - Associação Brasileira de Limpeza Pública, n.56, p.24-30, dez. 2001.

D'ALMEIDA, M. L. O; SENA, L. B. R. (2000) Reciclagem de Outras Matérias. In: Manual de Gerenciamento Integrado. IPT - Instituto de Pesquisas Tecnológicas. CEMPRE Compromisso Empresarial para Reciclagem. 2. ed. São Paulo: IPT, 2000.

EA (Environment Agency) - UK (Agência Ambiental Inglesa). (2001) In: EA Tyres Report. Disponível em: <http://www.environment-agency.gov.uk> Acesso em: 17 mai. 2008.

ECHIMENCO, L. Pneus usados rendem lucros. Jornal O Estado de São Paulo, São Paulo/ SP, Painel de Negócios, p. PN 1, 3 e 4.17 abr. 2001.

EPA - United States Environmental Protection Agency. Summary of Markets for Scrap Tires. In: U. S. Environmental Protection Agency. EPA/530. SW 90. 074B. Oct., 1991.

FAPEMIG - Fundação de Amparo à Pesquisa do Estado de Minas Gerais. Reciclagem de Pneus. In: Tecnologia - Revista Minas Faz Ciências, n. 10, mar.-mai., 2002. Disponível em: $<$ http://revista.fapemig.br/10/pneus.html >. Acesso em: 12 mar. 2008.

FAZENDA, J. M. R. Tintas e vernizes, ciência e tecnologia. São Paulo: Abrafati, 1993.

FIGUEIREDO, P. J. M. A sociedade do lixo: Os resíduos, a questão energética e a crise ambiental. Piracicaba: UNIMEP. 1994. 
GODOY, J. Estudo de um novo compósito madeira-resina poliuretana para o desenvolvimento de um isolador híbrido. 2007. 96 p. Dissertação (Mestrado em Engenharia Elétrica). Escola de Engenharia de São Carlos - EESC/USP. São Carlos, 2007.

GOMES, L. P. Estudo da caracterização física e da biodegradabilidade dos resíduos sólidos urbanos em aterros sanitários. São Carlos. 166p. Dissertação (Mestrado em Hidráulica e Saneamento). Escola de Engenharia de São Carlos, Universidade de São Paulo, 1989.

GÜNTHER, W. M. R. Minimização de resíduos e educação ambiental. Anais VII Seminário Nacional de Resíduos Sólidos e Limpeza Pública. ABLP - Associação Brasileira de Limpeza Pública; 2000.

HACKBART, Rolf; LIMA, de Titan. Destinação final aos pneus - análise da Resolução no 258/99, CONAMA. Disponível em: $<\mathrm{http}: / / \mathrm{www}$.assessoriadopt.org/pneus.htm>. Acesso em: 15 abr. 2008.

HEITZMAN, M. Design and Construction of Asphalt Paving Materials with Crumb Rubber Modifier. Transportation Research Record, 1339, TRB, National Research Council, Washington, D.C., p.1-8, 1992

IPCT - Instituto de Pesquisa, Ciência e Tecnologia. Meio Ambiente Industrial Revista. Disponível em: <http://www.meioambienteindustrial.com.br>. Acesso em: 17 abr. 2008.

JARDIM, N. S. et al. Lixo municipal: Manual de gerenciamento integrado. São Paulo: Instituto de Pesquisas Tecnológicas (IPT), e Compromisso Empresarial para Reciclagem (CEMPRE), 1995.

KELLY, J. Earthquake-Resistant design with rubber. 1st Edition Springer-Verlag, 1993.

LAPO, L. E. R.; BERALDO, A. L. Bambu laminado colado (BLC). Revista em Agronegócios e Meio Ambiente, v.1, n.2, p.165-177, mai./ago. 2008.

LEVINE, D. M. et al. Estatística: Teoria e aplicações usando Microsoft Excel Português. Rio de Janeiro: LTC, 2000.

LIMA, J. D. Gestão de Resíduos Sólidos Urbanos no Brasil. ABES - Associação Brasileira de Engenharia Sanitária e Ambiental, Seção Paraíba, 2000.

LUND, H. F. The McGraw - Hill Recycling Handbook. New York: McGraw - Hill, 1993. 
MAGANHA, M. F. B., KOMATSU, C. E. Pneus como alternativa energética. $5^{\circ}$ Congresso Brasileiro de Cimento. São Paulo: BPS, 1999. CD-ROM.

MANO, E. B. Introdução aos Polímeros. Editora Edgard Blücher Ltda., São Paulo, 1985.

MELO, N. V. Pneus e o mosquito da dengue. Limpeza Pública, n.47, p.31-32, 1998.

MENDES, R. K.; CAVALHEIRO, E. T. G. Desenvolvimento de um novo compósito a base de grafite e resina poliuretana, para aplicações eletroanalíticas. 2002. 150f. (Mestrado em Química). Universidade Federal de São Carlos. São Carlos, 2002.

MÍDIANEWS. Boletim informativo MídiaNews - meio Ambiente, Ciência e Tecnologia. CONAMA Discute Recolhimento Adequado de Pneus Usados. Disponível em: $<$ http://www.midianews.com.br $>$. Acesso em: 22 mar. 2008.

MILANESE, A. C. Caracterização de compósitos de matrizes poliméricas reforçadas com fibras de sisal e de vidro. 2008. 129f. Dissertação (Mestrado em Engenharia Mecânica). Faculdade de Engenharia do Campus de Guaratinguetá, Universidade Estadual Paulista, Guaratinguetá, 2008.

MMA, Ministério do Meio Ambiente. (2002) In: Resolução no 258, de 26 de agosto de 1999. Disponível em: <http://www.mma.gov.br>. Acesso em: 23 mai. 2008.

MMA. Ministério do Meio Ambiente (2002) In: Matéria do InforMMA "Sala de Imprensa": CONAMA Reforça Proibição da Importação de Pneus Usados. Disponível em: $<$ http://www.mma.gov.br>. Acesso em: 26 mai. 2008

MMA. Ministério do Meio Ambiente. (2002) In: Meio Ambiente Industrial. Disponível em: $<$ http://www.mma.gov.br>. Acesso em: 17 mai. 2008.

MOTHÉ, C. G.; ARAÚJO, C. R. Caracterização Térmica e Mecânica de Compósitos de Poliuretano com Fibras de Curauá. Revista Polímeros: Ciência e Tecnologia, v. 14, n. 4, p. 274-278, São Carlos, 2004.

PARANÁ. Lei n.12.493, de 22 de janeiro de 1999. Dispõe sobre as obrigações e responsabilidade na disposição de resíduos. Diário Oficial do Estado do Paraná, Curitiba, 23 jan. 1999.

RECICLOTECA. Centro de Informações sobre Reciclagem e Meio Ambiente. Borracha e o pneu. Disponível em: $<$ http://www.recicloteca.org.br/Default.asp?

Editoria $=5 \&$ SubEditoria $=19 \& I D=56 \&$ Ver=1>. Acesso em: 20 set. 2007. 
SANTOS, A. L. T. Plano de gerenciamento do pneu. Resíduo: metodologia. $122 \mathrm{f}$.

Dissertação (Mestrado em Engenharia Civil) - Faculdade de Engenharia Civil, Universidade Estadual de Campinas, Campinas, São Paulo, 2002.

SÃO PAULO. Resolução Conjunta SMA / SS - 1, de 5-3-2002. Disponível em: $<$ http://www.cetesb.sp.gov.br/Solo/residuos/res_conj_sma_ss_1.pdf $>$. Acesso em: 19 mai. 2008.

SCHULTZ, P. Painéis sanduíche constituídos de cimento reforçado com fibras (CRF) e compósito polimérico: pesquisa e desenvolvimento preliminar. 126f. Dissertação (Mestrado em Engenharia Civil). EESC - Escola Engenharia de São Carlos. USP, São Carlos, 2005.

SILVA, R. V. Compósito de resina poliuretano derivada do óleo de mamona e fibras vegetais. 2003. 157f. Tese (Doutorado em Ciências e Engenharia de Materiais). Universidade de São Paulo. São Carlos, 2003.

TCHOBANOGLOUS, G.; THEISEN, H.; ELLIASSEN, R. Integrated Solid Waste Management. New York: McGraw - Hill, 1993. p.758-760.

TOMMASINI, G. Pneus: Desafio da Reciclagem. In: Revista Auto Esporte, $n^{\circ}$ 421, ano 36, Seção Ponto de Vista, 2001. Disponível em: <http://www.revistaautoesporte.globo.com.pneus desafiosdareciclagem_arquivos\pontodevista.htm>. Acesso em: 15 mai. 2007.

VAN VLACH, L. H. Princípios de ciência dos materiais. São Paulo: Edgard Blücher, 1970.

WIEDMAN, G. A. Fibra de coco e resinas de origem vegetal para produção de componentes de mobiliário e da construção civil. 2002, 118 p, Tese (Doutorado em Arquitetura e Urbanismo). Faculdade de Arquitetura e Urbanismo - USP. São Paulo, 2002. 
ANEXOS 


\section{ANEXO A}

\section{Análise de Variância - ANOVA}

\section{$\underline{\text { Objetivo: }}$}

É uma coleção de modelos estatísticos e procedimentos. Serve para dizer se os valores de um grupo de dados numéricos são estatisticamente significativamente diferentes dos valores de outros grupos de dados.

O procedimento é baseado na variância global observada nos grupos a serem comparados. Geralmente, usa-se a ANOVA para fornecer uma probabilidade para a conclusão de que a média de um grupo é diferente da média de outro grupo.

\section{Assunções:}

- Independência entre as observações;

- A distribuição das observações de cada um dos grupos é normal;

- A variável deve ter mensuração ao menos intervalar;

- A variância dos dados de cada um dos grupos deve ser a mesma, ou seja, homogeneidade das variâncias.

\section{Hipóteses:}

$\mathrm{H}_{0}$ : Todos os grupos têm a mesma variância.

$\mathrm{H}_{1}$ : Algum dos grupos tem variância diferente. 
Estatística do Teste:

É definida a soma de quadrados total como:

$$
S Q T=\sum\left(x_{i}-\bar{x}\right)^{2}
$$

onde $\overline{\boldsymbol{x}}$ é a média total.

Pode-se reescrever como:

$$
S Q T=S Q D+S Q E,
$$

onde temos:

Soma de Quadrados Dentro de Grupo:

$$
S Q D=\sum_{g p 1}\left(x_{i}-\bar{x}_{1}\right)^{2}+\sum_{g p 2}\left(x_{i}-\bar{x}_{2}\right)^{2}+\sum_{g p 3}\left(x_{i}-\bar{x}_{3}\right)^{2}+\sum_{g p 4}\left(x_{i}-\bar{x}_{4}\right)^{2}
$$

\footnotetext{
$\overline{\bar{D}} \boldsymbol{k}$

em que é a média amostral do k-ésimo grupo e,
}

Soma de Quadrados Entre Grupos:

$$
S Q E=n_{1}\left(\overline{x_{1}}-\bar{x}\right)^{2}+n_{2}\left(\overline{x_{2}}-\bar{x}\right)^{2}+n_{3}\left(\overline{x_{3}}-\bar{x}\right)^{2}+n_{4}\left(\overline{x_{4}}-\bar{x}\right)^{2}
$$

na qual $n_{k}$ é o tamanho amostral do $k$-ésimo grupo.

A variância de uma amostra é dada por:

$$
s^{2}=S Q T /(n-1)
$$

Obtêm-se duas equações: 


$$
\begin{aligned}
& s_{1}^{2}=S Q E /(m-1) \\
& s_{2}^{2}=S Q D /(N-m)
\end{aligned}
$$

onde $m$ é o número de grupos e $N$ é o tamanho amostral total.

Finalmente tem-se a seguinte estatística do teste:

$$
F=s_{1}^{2} / s_{2}^{2}
$$

Para obter o p-valor, que diz qual a probabilidade de se ter o observado dado que a $\mathrm{H}_{0}$ é verdadeira, usa-se a probabilidade da distribuição $F$ de Fisher com $m-1$ e $N-m$ graus de liberdade.

Quanto menor for o $p$-valor mais evidências têm-se de que a hipótese de que as variâncias do grupo não é a mesma.

\section{TESTE $T$}

Às vezes, é preciso comparar duas populações a duas populações. Por exemplo, imagine que um pesquisador obteve, para um grande número de crianças, a idade em que cada uma delas começou a falar. Para verificar se meninos e meninas aprendem a falar na mesma idade, o pesquisador terá que comparar os dados dos dois sexos.

Outras vezes, é preciso comparar condições experimentais. Por exemplo, para saber se um tratamento tem efeito, organizam-se dois grupos de unidades: um grupo recebe o tratamento em teste (é o grupo tratado), enquanto o outro não recebe tratamento (é o grupo controle). O efeito do tratamento é dado pela comparação dos dois grupos. 


\section{Teste $T$ para observações independentes}

Se a variável em análise tem distribuição normal ou aproximadamente normal, aplicase o teste $\mathrm{t}$ para comparar duas médias. Mas primeiro é preciso estabelecer o nível de significância, que se indica pela letra grega $\alpha$. Depois, dados os dois grupos, 1 e 2, calculamse:

a) A média de cada grupo, indica-se:

$x:$ média do grupo 1

$x$ : média do grupo 2

b) A variância de cada grupo, indica-se:

$s$ : variância do grupo 1

$s$ : variância do grupo 2

c) A variância ponderada, dada pela fórmula:

$$
s=\frac{\left(n_{1}-1\right) s_{1}^{2}+\left(n_{2}-1\right) s_{2}^{2}}{n_{1}+n_{2}-2}
$$

onde $n$ é o número de elementos do grupo 1, e $n$ é o número de elementos do grupo 2.

d) $\mathrm{O}$ valor de $t$ definido por

$$
\tau=\frac{\bar{x}_{2}-\bar{x}_{1}}{\sqrt{s^{2}\left(\frac{1}{n_{1}}+\frac{1}{n_{2}}\right)}}
$$




\section{Teste $T$ para observações independentes quando as variâncias são desiguais.}

Existe uma regra prática para verificar se as variâncias são iguais: se a maior variância for igual até 4 vezes a menor, admite-se que as duas populações têm variâncias iguais. Por exemplo, se as amostras têm variâncias $s 1=15,62$ e $s 2=6,80$, tem-se que:

$$
\frac{s_{1}^{2}}{s_{2}^{2}}=\frac{15,64}{6,30}=2,30<4
$$

ou seja, é razoável admitir que as variâncias são iguais.

Porém se as variâncias são muito diferentes convém fazer o teste estatístico.

Para testar a hipótese de que as variâncias são iguais, aplica-se o teste F. Para isso, é preciso estabelecer o nível de significância. Depois é preciso calcular:

a) a variância de cada grupo indica-se:

$s=$ variância do grupo 1

$s=$ variância do grupo 2

b) o valor de F, dado pela razão entre o maior e a menor variância.

SE s1 > s2, o valor

$$
F=\frac{s_{1}^{2}}{s_{2}^{2}}
$$

está associado a $n-1$ (numerador) e $n-1$ (denominador) graus de liberdade.

Feitos os cálculos, é preciso procurar o valor de F na tabela, com nível de significância igual à metade do nível de significância estabelecido, e com $(n-1)$ e $(n-2)$ graus de liberdade. Toda vez que o valor calculado de $\mathrm{F}$ for igual ou maior do que o valor da tabela, 
rejeita-se a hipótese de que as variâncias da duas populações são iguais, ao nível de significância estabelecido.

Se as variâncias são desiguais, para comparar duas médias aplica-se o teste t, na forma descrita aqui. É preciso calcular:

a) a média de cada grupo. Indica-se

$x=$ média do grupo 1

$x=$ média do grupo 2

b) a variância de cada grupo, indica-se

$s=$ variância do grupo 1

$s=$ variância do grupo 2

c) valor de $t$, dado pela fórmula:

$$
t=\frac{\bar{x}_{2}-\bar{x}_{1}}{\sqrt{\frac{s_{1}^{2}}{n_{1}}+\frac{s_{2}^{2}}{n_{2}}}}
$$

onde $\mathrm{n}$,é o número de elementos do grupo 1 e n é o número de elementos do grupo 2.

d) o número de graus de liberdade associado ao valor de t, que é a parte inteira do número g, obtido pela fórmula:

$$
g=\frac{\frac{s_{1}^{2}}{n_{1}}+\frac{s_{2}^{2}}{n_{2}}}{\frac{\left(\frac{s_{1}^{2}}{n_{1}}\right)\left(\frac{s_{2}^{2}}{n_{2}}\right)}{n_{1}-1+n_{2}-1}}
$$

Feitos os cálculos, é preciso procurar o valor de t na tabela, ao nível de significância estabelecido e com g graus de liberdade. Toda vez que o valor absoluto de $\mathrm{t}$ calculado for 
igual ou maior do que o valor na tabela, conclui-se que as médias não são iguais, ao nível de significância estabelecido. 


\section{ANEXO B}

A análise dinâmico-mecânica (DMA) ou análise termodinâmico-mecânica (DMTA) tem como um dos principais objetivos relacionar as propriedades macroscópicas, tais como as propriedades mecânicas, às relaxações moleculares associadas a mudanças conformacionais e a deformações microscópicas geradas a partir de rearranjos moleculares.

As propriedades mecânicas dos materiais são avaliadas a partir de uma solicitação, na forma de uma deformação ou na aplicação de uma tensão, com o monitoramento da resposta do material, expressa como tensão ou como deformação, respectivamente. Ensaios mecânicos são classificados como estáticos, uma vez que se aplica ao material uma tensão ou deformação constante, ou a taxas constantes. Estes experimentos são destrutivos, já que uma de suas finalidades é a determinação de propriedades limite do material.

A análise dinâmico-mecânica consiste, de modo geral, em se aplicar uma tensão ou deformação mecânica oscilatória, normalmente senoidal, de baixa amplitude a um sólido ou líquido viscoso, medindo-se a deformação sofrida por este ou a tensão resultante, respectivamente, sob variação de freqüência ou de temperatura.

Considere um sólido linear (mola) submetido a uma deformação senoidal. A tensão resultante será também senoidal e em fase com a deformação. Para um material totalmente viscoso (amortecedor), porém, a tensão será proporcional à taxa de deformação e estará defasada com relação à deformação. Como esperado, os materiais visco elásticos exibem uma resposta intermediária entre o comportamento puramente elástico ou puramente viscoso, este comportamento está representado na Figura a seguir: 


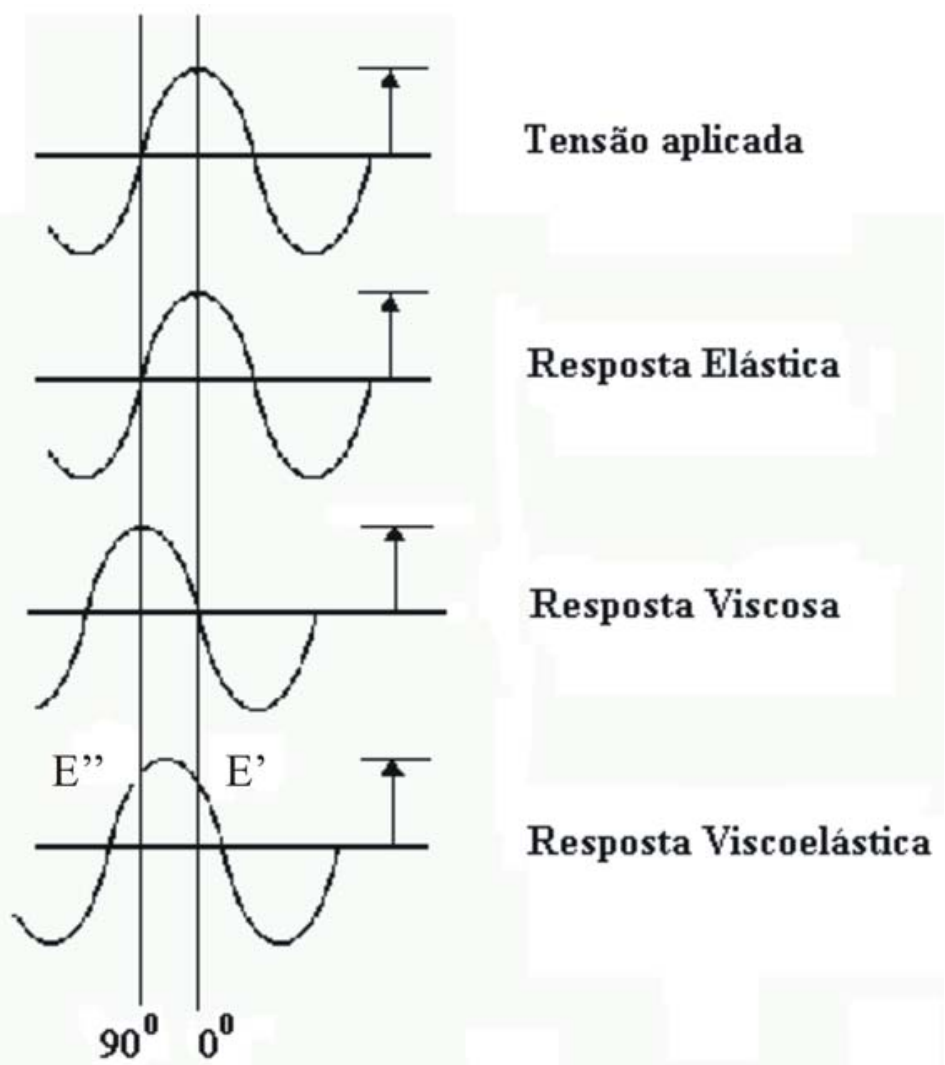

A tangente do ângulo de defasagem entre o sinal aplicado e a resposta do material corresponde à razão entre a energia viscosa, dissipada como calor em cada ciclo, denominada de módulo de perda, E", e a energia armazenada em cada ciclo, denominada de módulo de armazenamento, E'. Esta razão adimensional, tan $\delta$, é chamada de fator de dissipação ou tangente de perda, ou ainda, amortecimento ou atrito interno. 


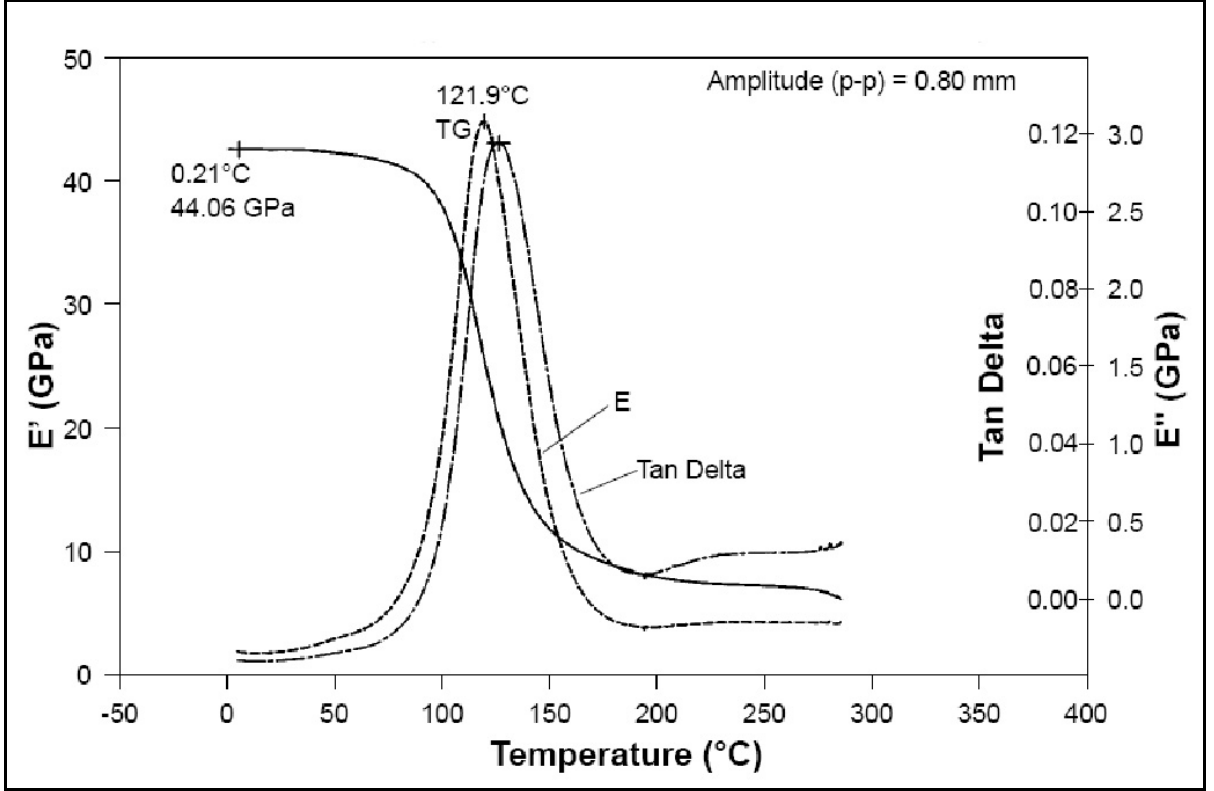

Os módulos dinâmicos de Young, $E^{*}$, e de cisalhamento, $\mathrm{G}^{*}$, podem ser expressos em notação de números complexos em suas componentes:

$$
\begin{aligned}
& E^{*}=E^{\prime}+E^{3} \\
& G^{*}=G^{\prime}+G^{n}
\end{aligned}
$$

Dividindo-se a Equações tem-se:

$$
\frac{E^{\prime \prime}}{E^{\prime}}=\frac{E^{*} \operatorname{sen} \delta}{E^{*} \cos \delta}=\tan \delta
$$

onde $\tan \delta$ é denominada de fator de perda ou "damping". Essa mesma relação é valida para os parâmetros obtidos em ensaios de cisalhamento, G*, G' e G’'

O “damping” expressa a capacidade de um material em converter energia mecânica. Sólidos que possuem apenas a componente elástica apresentam tan $\delta$ igual a zero. Exemplos de materiais que apresentam praticamente apenas a componente elástica são os metais e o quartzo. Polímeros, por outro lado, apresentam valores de $\delta$ da ordem de alguns graus: em certas faixas de temperatura, por exemplo, na região de transição vítrea. 


\section{Fluência - CREEP (Curvas Master)}

A determinação da fluência permite avaliar o comportamento do material quando submetido à ação de uma carga constante em que o módulo de elasticidade tende a decrescer com o tempo.

A Figura a seguir apresenta as curvas obtidas por um polímero a uma dada temperatura e em função do decaimento do módulo de elasticidade no tempo.

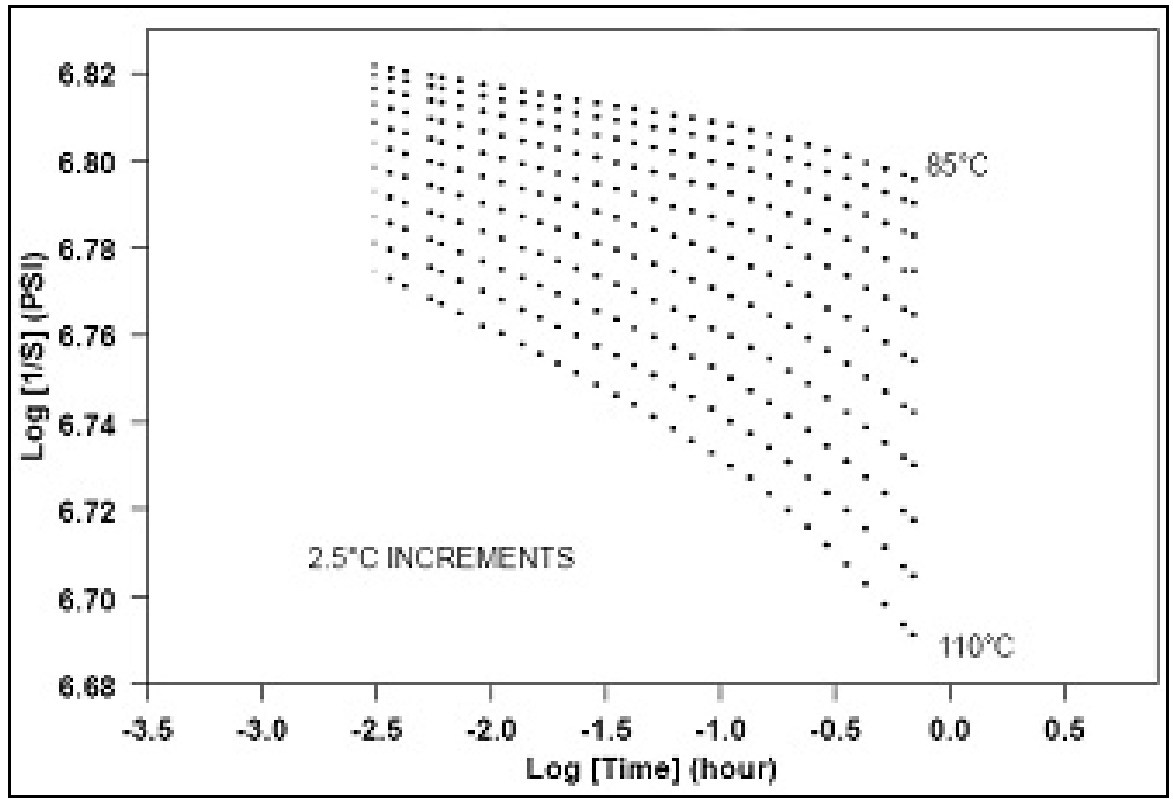

A associação das curvas segundo uma única curva, que melhor represente o comportamento do material na temperatura considerada é chamada de curva "master", a qual vai permitir avaliar o decaimento do módulo de elasticidade ao longo do tempo. 


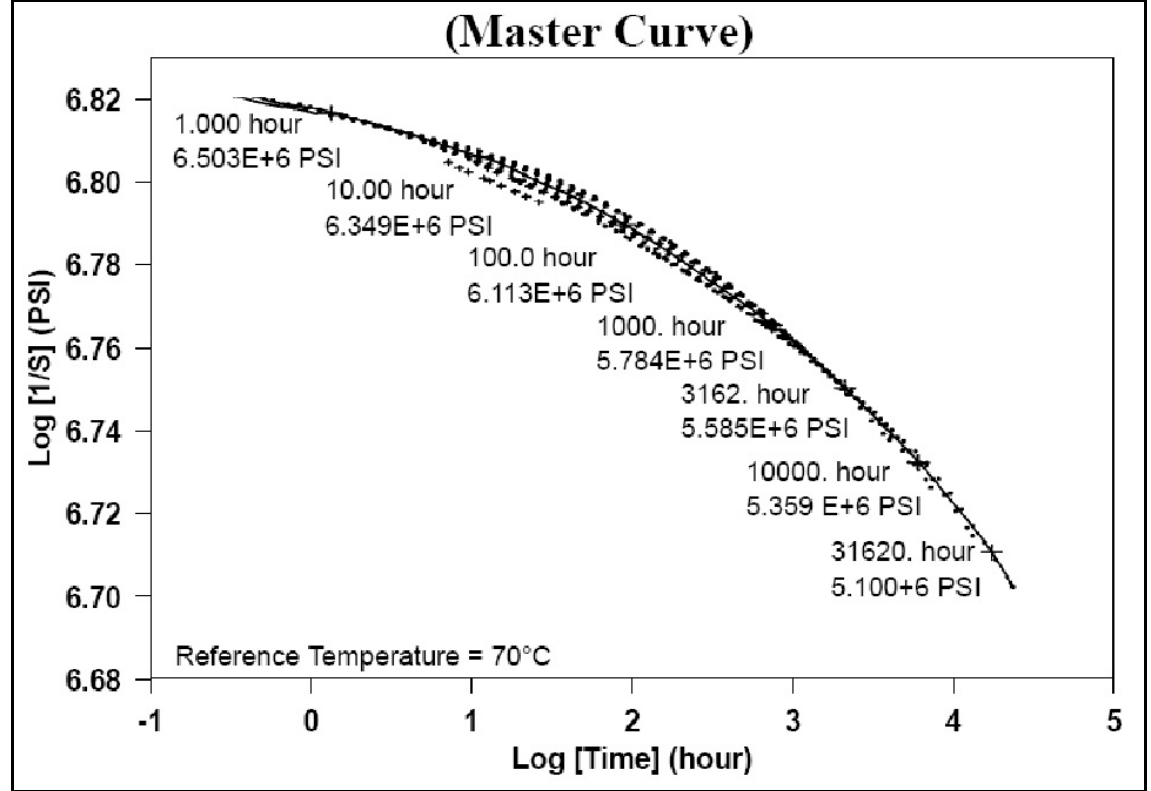

Fator de deslocamento $\left(\mathrm{a}_{\mathrm{T}}\right)$ em relação ao tempo

$$
a_{t}=\frac{t}{t_{R}}
$$

Onde $t$ é o tempo real para alcançar o valor da temperatura de referencia $t_{R}$ é o tempo correspondente ao valor do módulo na curva mestre na temperatura de referência

Em relação a viscosidade

$$
a_{\mathrm{T}=}=\frac{n}{n_{R}}
$$

Correção do módulo em relação a densidade e a Temperatura

$$
E\left(T_{R}, t_{R}\right)=\frac{\rho\left(T_{R}\right) T_{R}}{\rho(T) T} E(T, t)
$$




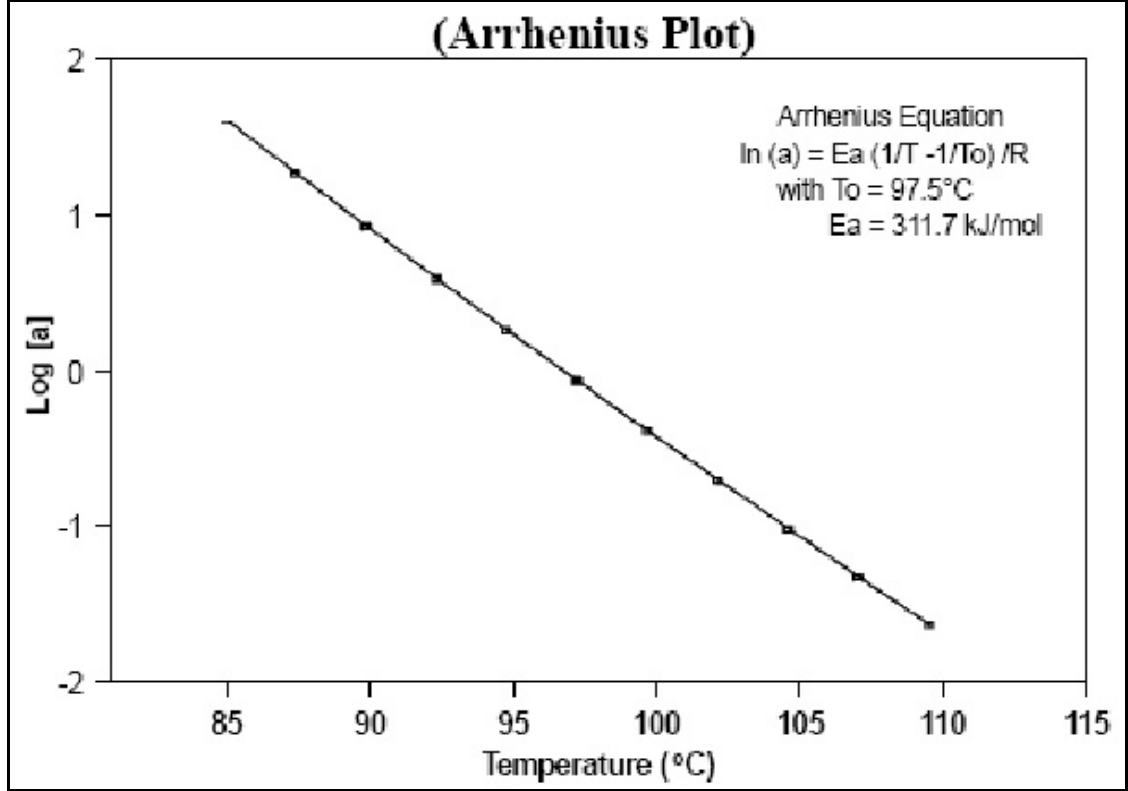

Polímeros amorfos seguem a equação de Arrhenius

O Fator de deslocamento $\left(\mathrm{a}_{\mathrm{T}}\right)$ pode ser aproximado pela expressão

$$
a_{T}=e^{b\left(\frac{1}{T}-\frac{1}{T_{0}}\right)}
$$

Rearranjando:

$$
\begin{aligned}
& \log a_{T}=\frac{-b}{2,3 T T_{0}}\left(T-T_{0}\right) \\
& \log a_{T}=\frac{-E_{a}}{R\left(T-T_{0}\right)}
\end{aligned}
$$

$\mathrm{Ea}=$ energia de ativação 


\section{Equação de Williams-Landel-Ferry (WLF)}

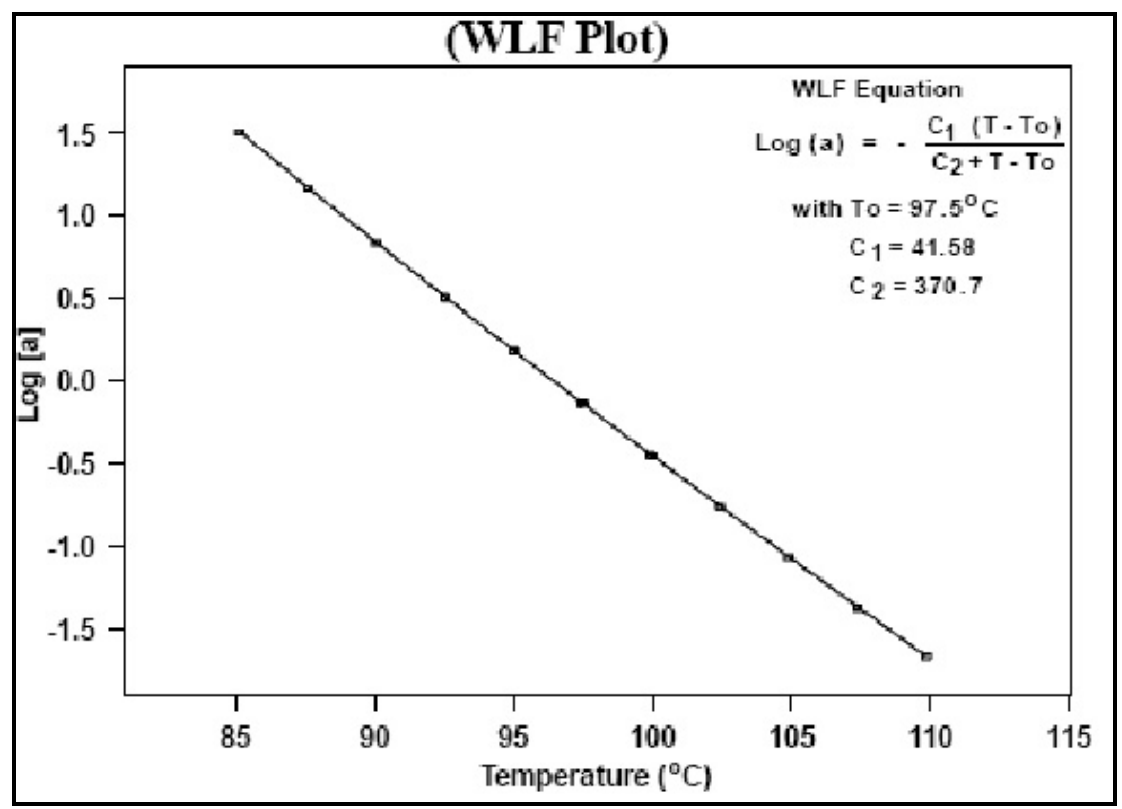

Dependência do Fator de deslocamento $\left(\mathrm{a}_{\mathrm{T}}\right)$ com a Temperatura é dada pela equação (valida para faixa de temperatura entre $\mathrm{Tg}$ e $\mathrm{Tg}+100^{\circ} \mathrm{C}$ )

$$
\log a_{T}=\frac{-C_{1}\left(T-T_{R}\right)}{C_{2}+T-T_{R}}
$$

Onde $\mathrm{C} 1$ e $\mathrm{C} 2$ são constante para determinado polímero $\mathrm{T}_{\mathrm{R}}$ é a temperatura de referência

Os valores de $\mathrm{C} 1$ e $\mathrm{C} 2$ estão relacionado ao volume livre fracional na $\mathrm{Tg}$ e ao coeficiente de expansão térmica do volume livre

Quando $\mathrm{T}_{\mathrm{R}}$ for igual a $\mathrm{Tg}, \mathrm{C} 1$ e $\mathrm{C} 2$, para polímeros amorfos, adquirem valores universais de 17,44 e 51,6 respectivamente. 


\section{ANEXO C}

\section{PANORAMA ATUAL DA COLETA DE PNEUS INSERVÍVEIS NO PAÍS}

O país conta hoje com 220 centros de recepção de pneus inservíveis - os chamados "Ecopontos" - e outros 17 pontos de coleta em 21 estados brasileiros.

O Programa foi responsável desde o seu início pela destinação de 644 mil toneladas de pneus inservíveis, o que equivale a cerca de 129 milhões de pneus de automóveis, com investimentos na ordem de US\$ 37 milhões.

Volume coletado em 2006 por região

Unidade: Quantidade equivalente em pneus de passeio

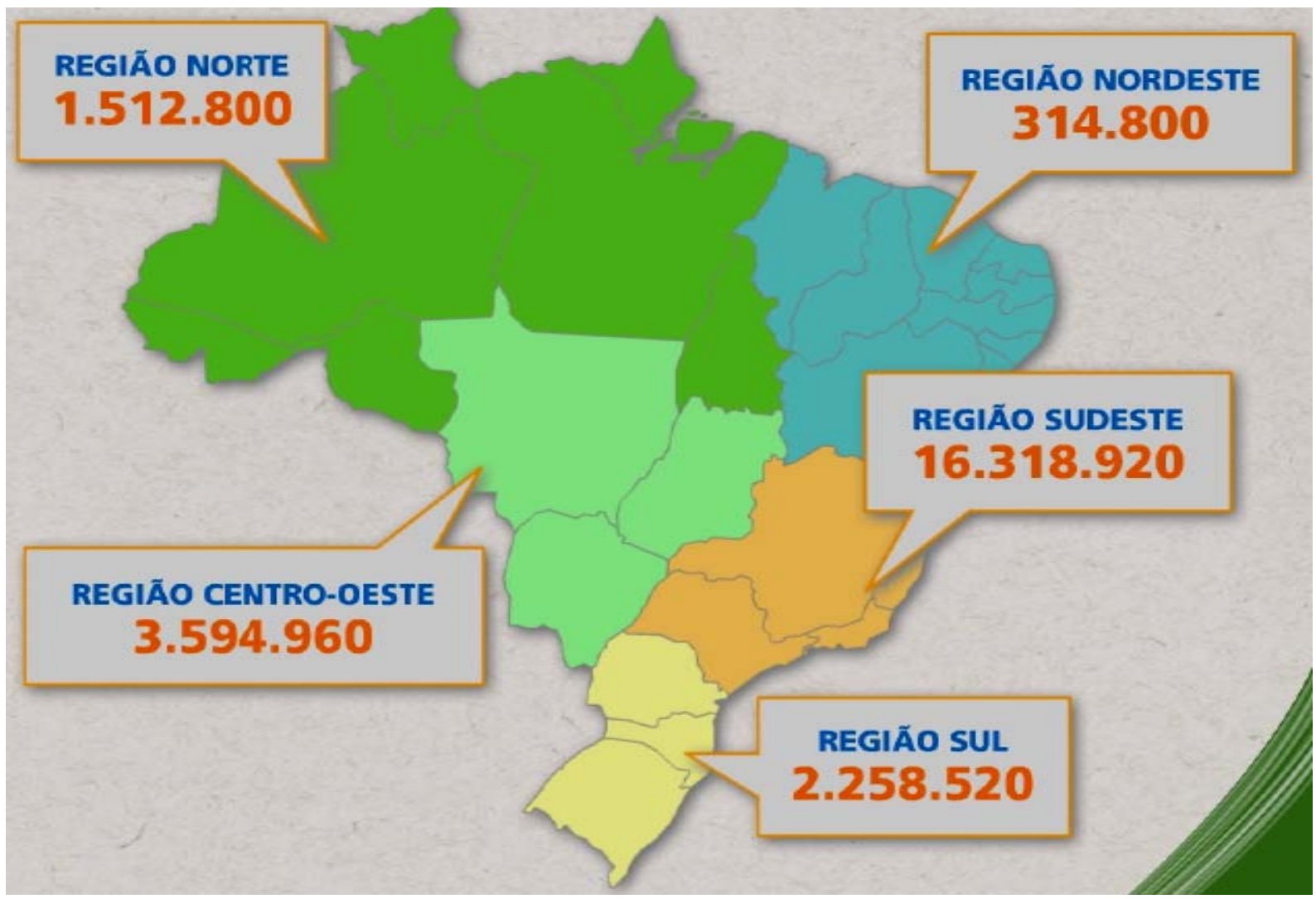


Para onde vão os pneus inservíveis:

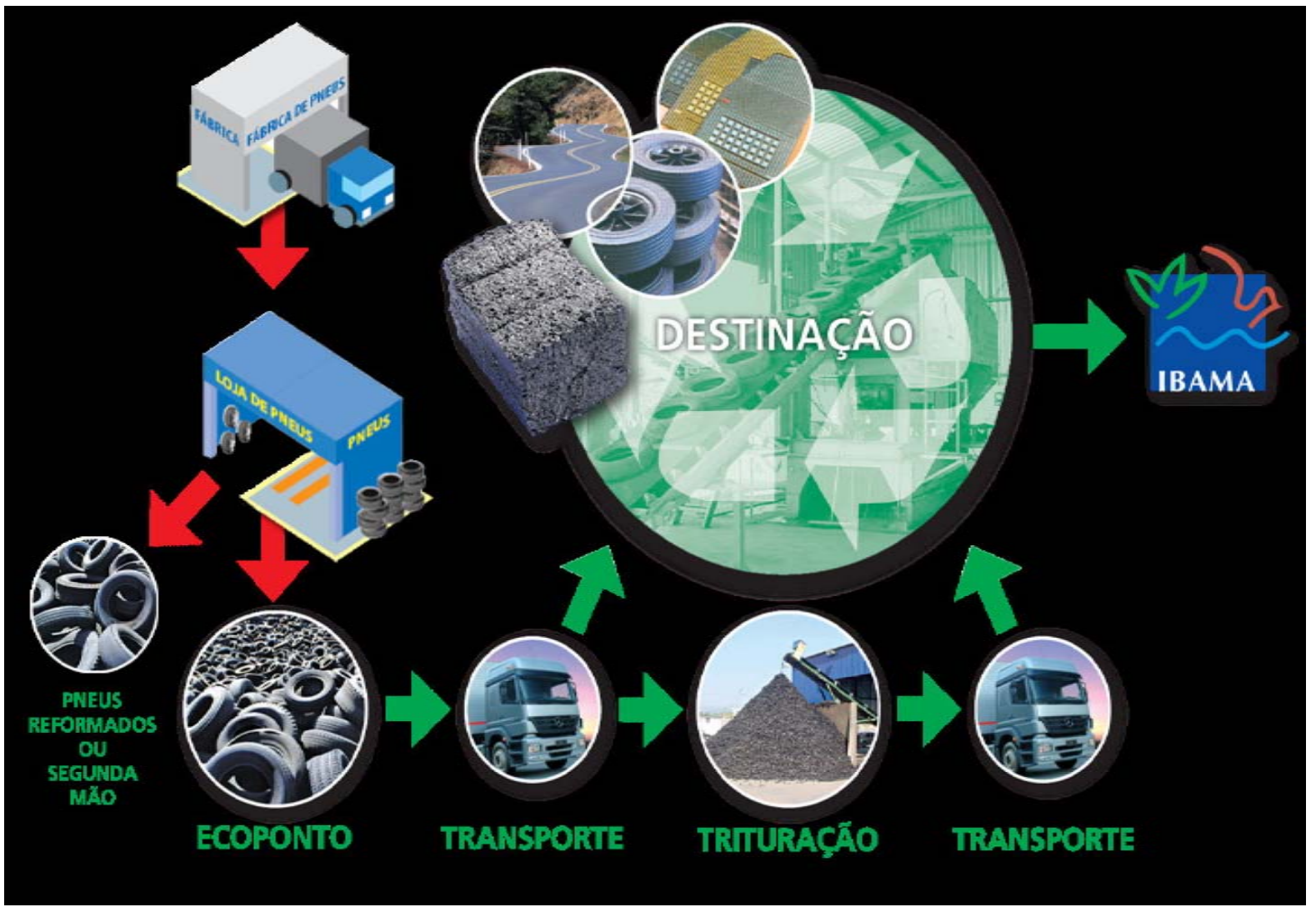

\section{Ecopontos}

São locais disponibilizados pelas Prefeituras Municipais através da celebração de Convênios de Cooperação Mútua, para onde são levados os pneus recolhidos pelo serviço público ou descartados voluntariamente por borracheiros, lojas de pneus, munícipes e outros.

Os pneus ficam armazenados temporariamente nos ecopontos até a sua retirada por parceiros do programa sob a demanda da Reciclanip, garantindo a destinação final ambientalmente adequada. 


\section{NÚMERO DE ECOPONTOS}

\section{0}

\section{5}

85

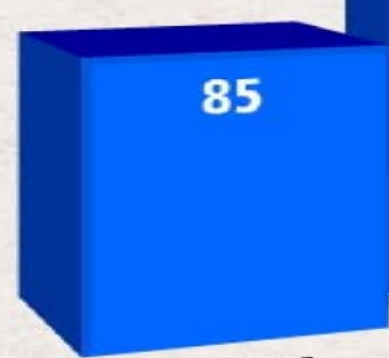

2004

Destinação Atual dos Pneus Inservíveis

- Co-processamento: Utilização dos pneus como combustível alternativo em fornos de cimenteiras em substituição ao carvão coque.

- Laminação: Utilização de pneus não radiais para fabricação de percintas (Indústrias moveleiras), solas de sapato, dutos de águas pluviais, etc.

- Asfalto borracha: Adesão à massa asfaltica de pó de borracha oriunda de pneus inservíveis que promove o aumento da vida útil do asfalto, diminuição de ruídos, além de maior segurança ao usuário das rodovias.

- Artefatos de borracha: Tapetes, pisos, etc. 
Total de Ecopontos Segundo a Reciclanip

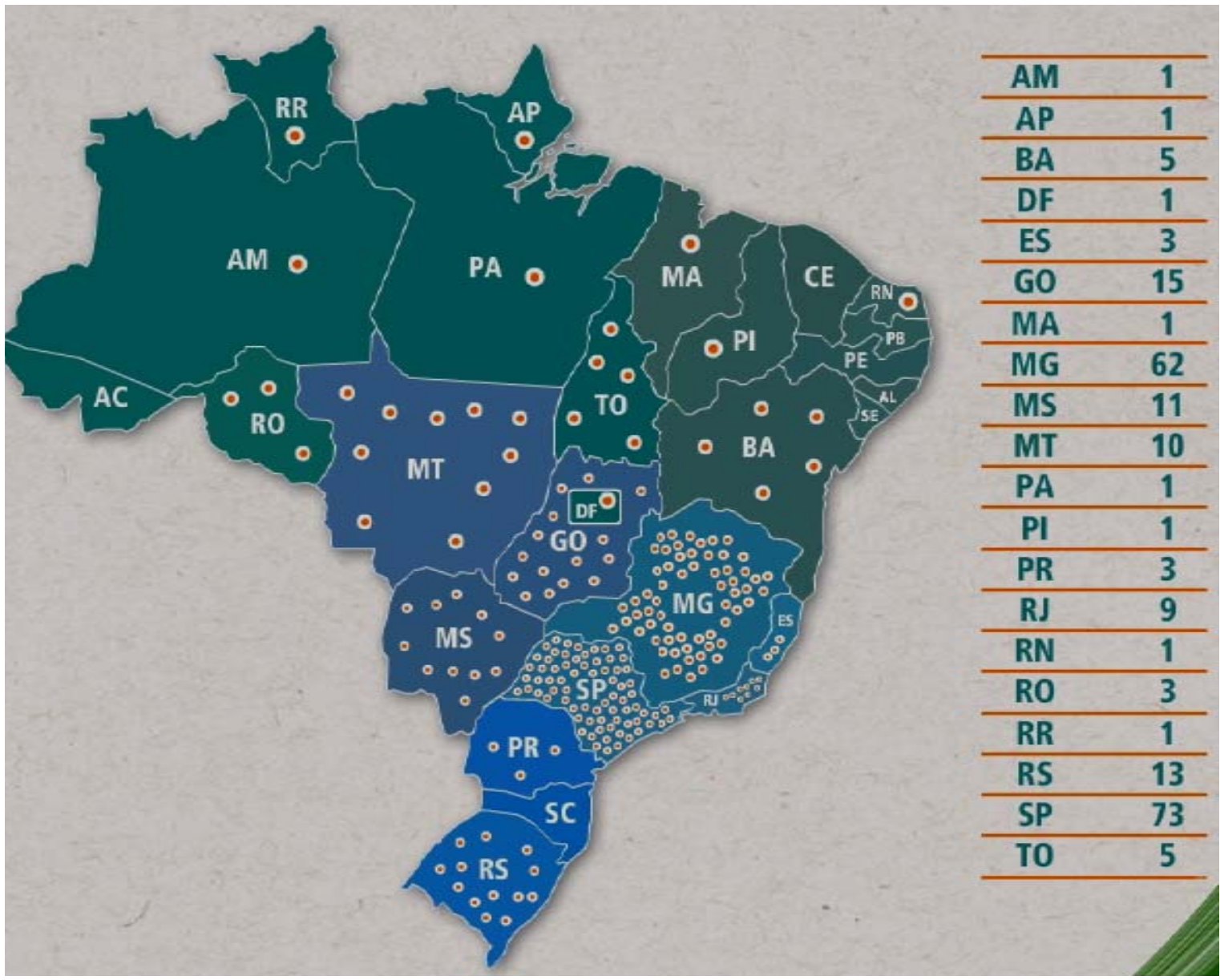

